\title{
Systematics and biogeography of selected genera in Lejeuneaceae subfamily Lejeuneoideae
}

\author{
Dissertation for the award of the degree \\ "Doctor rerum naturalium" (Dr.rer.nat.) \\ of the Georg-August-Universität Göttingen \\ within the doctoral program Biology \\ of the Georg-August-Universität Göttingen
}

submitted by Shanshan Dong

from Xi'an, China

Göttingen, August 2013 
Thesis Committee

Prof. Dr. Jochen Heinrichs, LMU Department für Biologie, München University.

PD. Dr. Alexander R. Schmidt, Courant Research Centre "'Geobiology"., Georg-AugustUniversität Göttingen

Members of the Examination Board

Reviewer: Prof. Dr. Jochen Heinrichs, LMU Department für Biologie, München University

Second Reviewer: PD. Dr. Alexander R. Schmidt,Courant Research Centre "Geobiology"., Georg-August-Universität Göttingen

Further members of the Examination Board:

Prof. Dr. Elvira Hörandl, Systematic Botany , Georg-August-Universitüät Göttingen

Prof. Dr. Hermann Behling, Department of Palynology and Climate Dynamics, Georg-August-Universitäät Göttingen

Prof. Dr. Holger Kreft, Free Floater Research Group - Biodiversity Macroecology, and Conservation Biogeography, Georg-August-Universität Göttingen

Prof Dr. Markus Hauck Plant Ecology and Ecosystem Research Georg-AugustUniversitäät Göttingen

Date of the oral examination: $18: 20$ November $6^{\text {th }}, 2013$ 


\section{Contents}

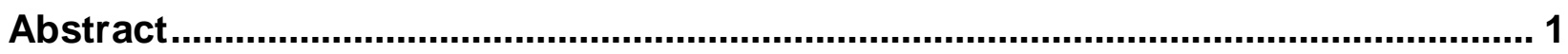

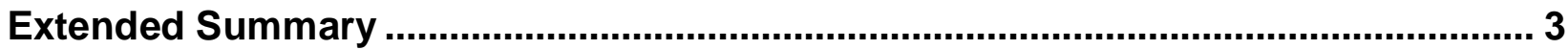

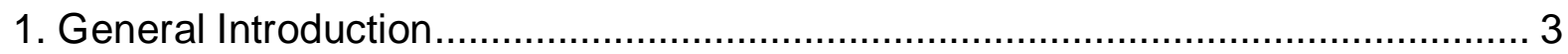

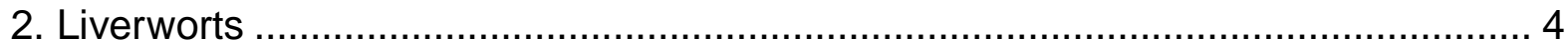

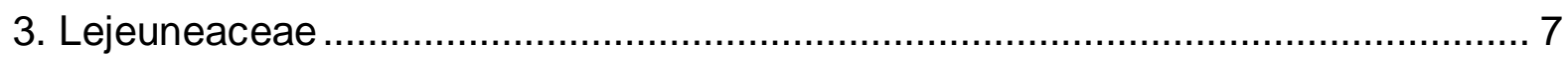

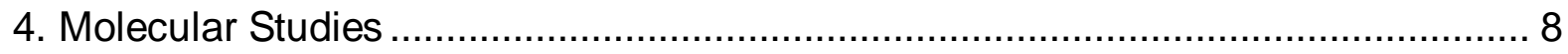

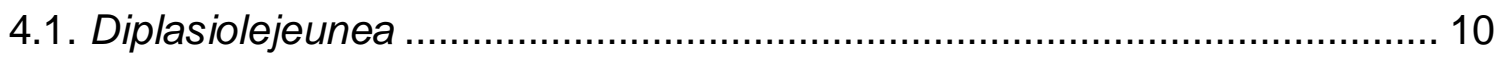

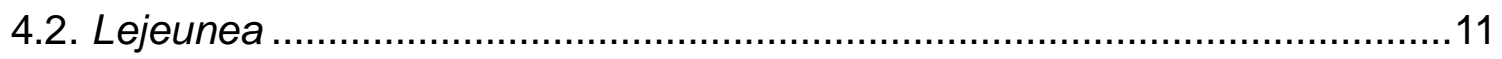

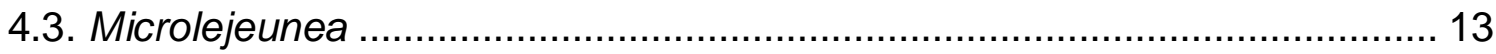

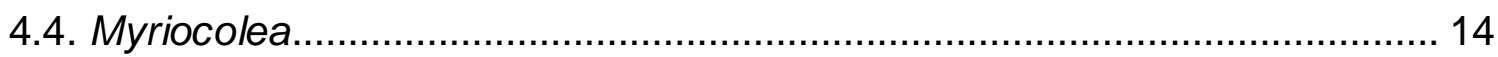

4.5. Sphaerolejeunea ............................................................................. 14

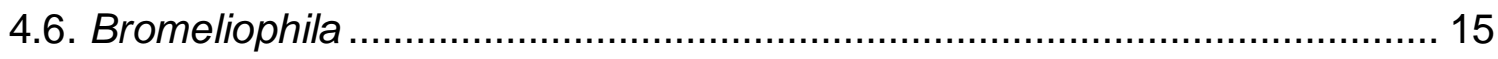

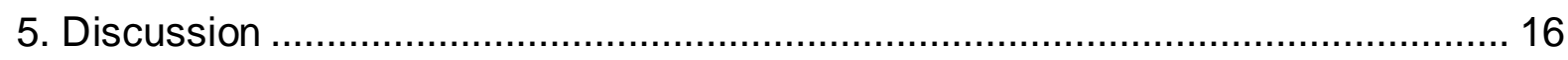

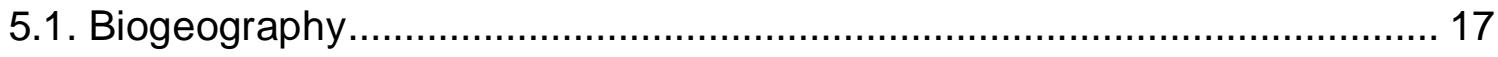

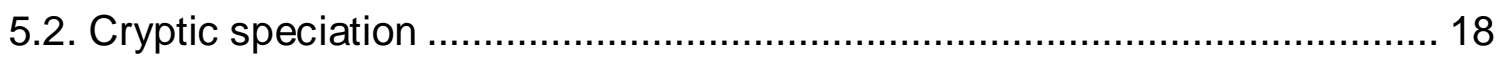

5.3. Taxa relocation .................................................................................. 19

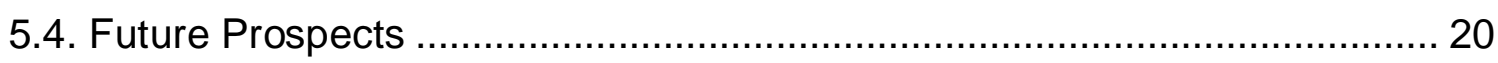

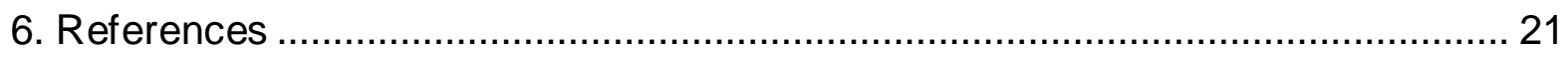

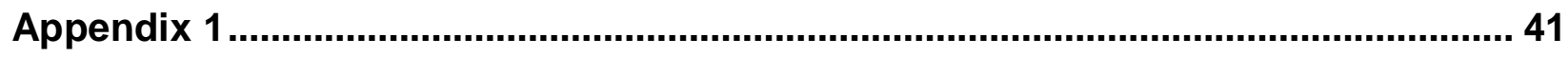

Tramps, narrow endemics and morphologically cryptic species in the epiphyllous

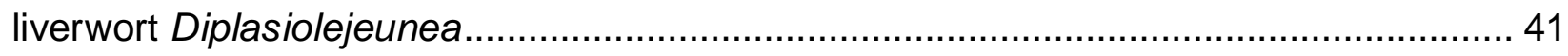

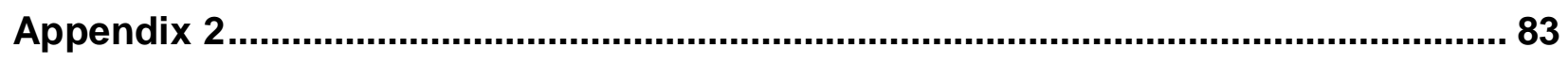

Molecular phylogeny of the leafy liverwort Lejeunea (Porellales): Evidence for a 
Neotropical origin, uneven distribution of sexual systems and insufficient taxonomy..... 83 Appendix 3

Size doesn't matter - recircumscription of Microlejeunea (Lejeuneaceae, Porellales) based on molecular and morphological evidence

Appendix 4

Molecular study of Myriocolea: A 150-year old mystery solved: Transfer of the rheophytic endemic liverwort Myriocolea irrorata to Colura 175

Appendix 5

Sphaerolejeunea (Lejeuneaceae, Porellales) is a synonym of Lejeunea.

Appendix 6

The Bromeliaceae tank dweller Bromeliophila (Lejeuneaceae, Porellales) is a member of the Cyclolejeunea-Prionolejeunea clade 215

Acknowledgments

Curriculum vitae. 


\begin{abstract}
Lejeuneaceae represent the most species-rich epiphytic lineage of leafy liverworts with approximately 1000 species in 68 currently accepted genera. This subcosmopolitan family has its centre of diversity in the humid tropics and constitutes an important component of cryptogamic, especially epiphytic diversity. Lejeuneaceae are characterized by incubous leaves divided into a large dorsal lobe and a small ventral, usually 1-3 toothed lobule which is broadly attached to the lobe along a keel, a hyaline papilla situated near the lobule apex, beaked perianths within each one archegonium, and the occasional occurrence of ocelli. Morphological and molecular studies resolved the family in two subfamilies and four main lineages. However, the systematic position of many taxa and their delimitations are still subject to controversy. To clarify these issues, my study focused on several critical genera using three molecular markers ( $c p r b c L$ and trnL-F, nrITS) and a dense taxonomic sampling. Phylogenetic analyses resolved the relationships within Diplasiolejeunea and Lejeunea, and clarified the systematic positions of Microlejeunea, Harpalejeunea, Myriocolea, Sphaerolejeunea, and Bromeliophila.
\end{abstract}

A molecular phylogenetic study of Diplasiolejeunea points to extensive morphological homoplasy but allows to assign three main clades to subgenera. The phylogeny supports a deep split into a Neotropical and a Paleotropical clade, the latter structured into Australasian, Asian and Afromadagascan lineages. The Neotropical clade is further subdivided into two geographically and ecologically separated lineages, the epiphytic montane subgenus Physolejeunea and the epiphyllous lowland subgenus Diplasiolejeunea. This strong correlation between ecological traits and geographical distribution range could indicate the rise of the Andes' influence in stimulating the diversification of Physolejeunea, perhaps by providing new habitats. A few Diplasiolejeunea species have intercontinental ranges. Range formation of Cenozoic Diplasiolejeunea is obviously a result of rare long distance dispersal, frequent short distance dispersal, extinction, recolonization, and niche conservatism. 
Lejeunea is one of the largest genera of Lejeuneaceae. My molecular studies resolved Lejeunea in two robust lineages, corresponding to $L$. subg. Lejeunea and $L$. subg. Crossotolejeunea. Neotropical accessions dominate early diverging lineages of both main clades of Lejeunea. This pattern suggests an origin in the Neotropics followed by several colonizations from the Neotropics into the Paleotropics and vice versa. Most Afromadagascan clades are related to Asian clades. Several temperate Lejeunea radiations were detected. 82 of the 91 investigated Lejeunea species could be identified to species level. 54 species were represented by multiple accessions, of these, 25 paraor polyphyletic, 29 monophyletic. L. subg. Lejeunea shows a tendency of monoecy whereas $L$. subg. Crossotolejeunea shows a tendency of dioecy. Some dioecious as well as some monoecious species have disjunct ranges. Using molecular and morphological evidence, Harpalejeunea fischeri, $H$. filicuspis, $H$. latitans and Pluvianthus squarrosus were transferred to Microlejeunea. Two monotypic genera, rheophytic Myriocolea and epiphyllous Sphaerolejeunea were transferred to Colura and Lejeunea respectively. Our studies also confirmed the monophyly of Bromeliophila and provided evidence for a sister relationship of Bromeliophila and Prionolejeunea; this clade is in turn sister to Cyclolejeunea. Despite an extensive morphological overlap, Bromeliophila is not closely related to Lejeunea. 


\section{Extended Summary}

This dissertation is about the molecular phylogenetic studies of several critical genera within family Lejeuneaceae. In Extended Summary chapter, section 1 to section 3 introduces Lejeuneaceae and reviews the state of research that has been done on this family. Section 4 reviews the molecular studies that I have done on this family. Section 5 summarizes results from all my studies and discusses possibilities for future work. The Appendix chapter includes all the publications during my studies on Lejeuneaceae.

\section{General Introduction}

Extant Viridiplantae includes two divisions, Chlorophyta and Streptophyta, the latter encompasses all embryophytes and a paraphyletic assemblage of Charophycean algae. The evolution and diversification of land plants from a group of Charophycean algae about 470-500 million years ago (Wodniok et al., 2011) was a major event in the earth's history, which lead to the terrestrial ecosystem today. Instead of morphologically most complex Charales (Karol et al., 2001; Qu, 2008; Qiu et al., 2006), recent studies resolved the unicellular and filamentous conjugating green algae Zygnematales (Timme et al., 2012; Turmel et al., 2007; Wodniok et al., 2011) or a clade containing Coleochaetales and Zygnematales (Laurin-Lemay et al., 2012; Turmel et al., 2002; Turmel et al., 2006; Wodniok et al., 2011) as the sister group of land plants.

Bryophytes are a collective term for liverworts, mosses, and hornworts and represent the earliest divergences of land plants. Although the precise divergent order of these early lineages has been the subject of debate (Garbary et al., 1993; Goremykin and Hellwig, 2005; Groth-Malonek and Knoop, 2005; Kelch et al., 2004; Nishiyama et al., 2004; Renzaglia et al., 2000), multiple lines of evidence suggest that three bryophyte clades form a paraphyletic grade at the base of embryophytes with liverworts resolved as the earliest divergence and mosses as sister to horworts and polysporangiophytes. Alternative topologies resolving the hornworts as sister to mosses plus polysporangiophytes are less well supported (Chang and Graham, 2011; Qiu, 2008; Qiu et al., 2006). The hypothesis behind this scenario is the pressure towards sporophytes' growing increasing autonomy as the major evolutionary drive, i.e., development of shoot 
apical meristem, photosynthetic activity, water conducting tissue, and longevity (Ligrone et al., 2012). The three bryophyte clades share a haploid dominant life cycle with unbranched sporophytes growing attached to the gametophytes. Sporophyte development in liverworts depends only on embryonic formative cell division and expansion. Moss sporophytes are mainly developed by a transient basal meristem which, however, acquires indeterminate activity in hornworts and polysporangiophytes (Kato and Akiyama, 2005; Ligrone et al., 2012). Recent functional analysis reveals that KNOX1 genes are regulators of sporophytic (diploid) meristematic genes (Sakakibara et al., 2008; Sano et al., 2005; Singer and Ashton, 2007). KNOX2 genes are regulators maintaining diploid differentiation by suppression of the gametophytic development program (Sakakibara et al., 2013). Reorganization and duplication of KNOX1/KNOX2 could help to establish the multi-cellule diploid generation.

\section{Liverworts}

Spore and tubular remains with apparent liverwort affinities date back to the Ordovician (ca. $470 \mathrm{Ma}$ ) (Wellman et al., 2003). The earliest macrofossil assigned to liverworts is the Lower Devonian (407-411 Ma) Riccardiothallus devonicus (Guo et al., 2012), which was recently added to the two other Devonian liverworts, Metzgeriothallus sharonae (385-392Ma) (Hernick et al., 2008) and Pallaviciniites devonicus (Hueber) R.M.Schust. (Oostendorp, 1987). Different from other bryophytes, liverwort sporophytes mature within its gametophyte confines and lack differentiations of stomata, columella or meristematic tissue. Based on gametophyte growth forms, liverworts are traditionally subdivided into two main groups, the Marchantioids (complex thalloid liverworts) and the Jungermannioids (simple thalloid and leafy liverworts). Current estimates are close to 7500 liverwort species (Von Konrat et al., 2010) in 376 genera and 74 families (CrandallStotler and Stotler, 2000), of which at least $85 \%$ are leafy Jungermannioids (Schuster, 1984).

During the past decade, molecular studies have greatly improved our understanding of liverwort phylogeny (Crandall-Stotler et al., 2009; Crandall-Stotler et al., 2005; Davis, 2004; Forrest and Crandall-Stotler, 2005; He-Nygren et al., 2006; Heinrichs et al., 2005a; Knoop, 2010; Lewis et al., 1997; Vilnet et al., 2009; Wahrmund et al., 2008). Based on 
the 18S rRNA gene, Capesius (1995) and Capesius and Bopp (1997) proposed that liverworts are polyphyletic. A $24 \mathrm{cp}$-rbcL dataset (Lewis et al., 1997) also tended to support this hypothesis albeit with weak support. However, subsequent comprehensive studies (Beckert et al., 1999; Duff and Nickrent, 1999; Nishiyama and Kato, 1999; Samigullin et al., 1998) with dense sampling and multiple genes unanimously supported the monophyly of liverworts. Stech and Frey (2001) divided liverworts into four classes: Jungermanniopsida, Marchantiopsida, Treubiopsida and Blasiopsida, based on trnL-F sequences. Heinrichs et al. (2005a), He-Nygren et al. (2006), and Forrest et al. (2006) revealed similar patterns but adopted three classes, Haplomitriopsida, Marchantiopsida and Jungermanniopsida. Meanwhile, the systematic positions of many liverwort groups have been clarified by molecular studies. Forrest and Crandall-Stotler (2004) and Crandall-Stotler et al. (2005) resolved a paraphyletic Metzgeriidae and pointed to extensive morphological homoplasy within this subclass. Wheeler (2000) supported the monophyly of subclass Marchantiidae encompassing three orders: Marchantiales, Sphaerocarpales, Monocleales, Boisselier-Dubayle et al. (2002) further pointed out that Sphaerocarpales and Monocleales are nested within Marchantiales. Their study on Marchantiidae indicated high degree of incongruence between molecular and morphological evidence, supporting a trend of morphological reduction in Marchantiidae in molecular and combined trees. Long (2006) proposed four new higher taxa for complex thalloid liverworts: families Dumortieraceae and Neohodgsoniaceae, orders Neohodgsoniales and Lunulariales. Schill et al. (2010) divided Mannia into the subgenera Mannia and Neesiella, and synonymized Asterella subg. Graciles with Mannia subg. Neesiella. Rubasinghe et al. (2011) resolved Cleveaceae in four lineages, corresponding to Sauteria, Peltolepis, Clevea and a narrowly defined Athalamia. So far, leafy liverworts were most intensively studied. Many familial and genus level molecular phylogenies have been produced, e.g., Adelanthaceae (Feldberg et al., 2010), Bryopteris (Hartmann et al., 2006), Frullania (Heinrichs et al., 2012a; Hentschel et al., 2009), Herbertus (Feldberg and Heinrichs, 2006), Lejeuneaceae (Sukkharak et al., 2011; Wilson et al., 2004; Wilson et al., 2007a), Lepidoziaceae (Cooper et al., 2012a; Cooper et al., 2011), Jubula (Pätsch et al., 2010), Leptoscyphus (Devos and Vanderpoorten, 2009), Lophozia (Vilnet et al., 2008), Plagiochila (Heinrichs et al., 2006), Porella (Hentschel et al., 2007b), Ptilidium (Kreier et al., 2010), and Scapania (Heinrichs et al., 
2012c).

Divergence time estimates suggest a Late Ordovician origin of Marchantiophyta, a separation of Haplomitriopsida from the remainder of liverworts in the Early Devonian, a split of Jungermanniopsida and Marchantiopsida in the Late Devonian, and a separation of Metzgeriidae and Jungermanniidae in the Late Carboniferous (Heinrichs et al., 2007). Leafy Jungermanniidae split into Porellales and Jungermanniales in the Early-Middle Permian but many extant genera and families date back only to the Cretaceous and Early Cenozoic. Other dating studies (Cooper et al., 2012b; Hartmann et al., 2006; Wilson et al., 2007b) also support that much of the family level diversity of liverworts was established in the Cretaceous, and much of the genus level diversity in the Cenozoic. Extensive diversification of leafy lineages within the Cenozoic might relate to changes in forest composition. The prosperity of angiosperm-dominated forests and increased forest complexity might provide various new niches for liverwort lineages to diversify (Cooper et al., 2012b; Heinrichs et al., 2007). Based on family level analysis of embryophyte divergence times, Fiz-Palacios et al. (2011) proposed that ferns and mosses radiated in the shadow of angiosperms while for liverworts and gymnosperms such patterns were not detected. However, Cooper et al. (2012b) doubted this "slowdown" in liverwort diversification patterns because a family level sampling often results in oversampling of deep nodes and strongly biased inferences towards downturns (Cusimano and Renner, 2010).

Liverworts are a group of simple plants with conserved morphological characters and long evolutionary history (Heinrichs et al., 2007; Magill, 2010; Shaw et al., 2011), which is often related to evolutionary stasis and lack of genetic potential (Frahm, $2000 \& 2004$; Pfeiffer, 2000). Geographic patterns within this lineage are thus sometimes attributed to ancient geological events (Devos and Vanderpoorten, 2009; Schaumann et al., 2003; Stech and Frey, 2004). However, patterns on the first sight congruent with ancient vicariance scenarios may in fact conceal a complex mixture of relictual distributions and more recent speciation and dispersal events (Devos and Vanderpoorten, 2009). Recent molecular dating brings back dispersal hypotheses (Hartmann et al., 2006; Heinrichs et al., 2009) or invokes more complex scenarios for putative Gondwanan disjunctions including Laurasian migration (Davis et al., 2002; Weeks et al., 2005). The spores of 
many widespread bryophyte species can withstand long periods of desiccation, high levels of UV radiation, and temperature extremes (van Zanten, 1978; Van Zanten and Pócs, 1981). Local and regional dispersal appears to be quite effective in many species, at least in those that regularly produce spores or propagules (Snall et al., 2004; Zartman et al., 2006; Zartman and Nascimento, 2006). Many studies also indicate bryophyte dispersal is sufficient even at continental scales to genetically homogenize plants (Cronberg, 2002; Grundmann et al., 2007; Van der Velde and Bijlsma, 2003; Vanderpoorten et al., 2008). In general, morphologically circumscribed bryophyte species usually have wider distribution ranges than vascular plants (Shaw, 2001). Intercontinental distribution ranges have been proposed for many liverwort species. These hypotheses have partly been confirmed by molecular data, e.g., for Frullania arecae and F. ericoides (Hentschel et al., 2009), F. tamarisci (Heinrichs et al., 2010), Herbertus juniperoideus (Feldberg et al., 2007), Metzgeria pubescens (Fuselier et al., 2011), Plagiochila boryana (Heinrichs et al., 2005b), P. corrugata (Heinrichs et al., 2004), Porella cordaeana (Heinrichs et al., 2011) and Porella swartziana (Hentschel et al., 2007b), as well as Scapania nemorea, S. paludosa, S. subalpina and S. undulata (Heinrichs et al., 2012c).

\section{Lejeuneaceae}

Leafy Jungermanniidae split in two orders assigned to as Porellales and Jungermanniales (Heinrichs et al., 2005a). Jungermanniales contain mainly terrestrial species characterized by often diffusely distributed rhizoids, lateral and ventral branching, unicellular spores and frequent presence of mycorrhiza-like mutualisms. Porellales contain mainly epiphytic species and are characterized by lack of ventral branching and mycorrhiza-like mutualisms, rhizoids in bundles, frequent occurrence of endosporous protonemata, incubous foliation and the development of watersacs (Gradstein et al., 2001; Heinrichs et al., 2005a; Schuster, 1980).

Lejeuneaceae represents the most species-rich epiphytic family of liverworts with some 1000 species in 68 currently accepted genera (Gradstein, 2013). This family has its centre of diversity in the humid tropics and constitutes an important component of 
cryptogamic, especially epiphytic diversity (Gradstein, 1997; Gradstein et al., 2006). Studies show that up to $70 \%$ of liverwort species of tropical lowland forests belong to Lejeuneaceae (Cornelissen and Ter Steege, 1989; Zartman, 2003). This family is characterized by incubous leaves divided into a large dorsal lobe and a small ventral, usually 1-3 toothed lobule which is broadly attached to the lobe along a keel, a hyaline papilla situated near the lobule apex, beaked perianths within each one archegonium, and the occasional occurrence of ocelli.

Spruce (1884) accepted only two genera in Lejeuneaceae, the monospecific genus Myriocolea and the speciose genus Lejeunea which he classified in 39 subgenera. Subsequent authors classified Lejeuneaceae into two artificial groups, "Holostipae" and "Schizostipae" based on either entire or bifid underleaves (Evans, 1935; Schuster, 1963). Herzog (1957) divided Lejeuneaceae into Lejeuneoideae and Cololejeuneoideae based on the number of underleaves per leaf pair. Mizutani (1961) recognized that "Holostipae" and "Schizostipae" differ constantly by sporophytic characters, and he renamed the two subfamilies Ptychanthoideae (Holostipae) and Lejeuneoideae (Schizostipae). Later, Mizutani (1985) merged Cololejeuneoideae with Lejeuneoideae. Recent morphological and molecular phylogenetic analyses (Gradstein et al., 2003; Heinrichs et al., 2005a; Wilson et al., 2004; Wilson et al., 2007a) recovered a paraphyletic Ptychanthoideae (19 genera) and a monophyletic Lejeuneoideae (49 genera), the latter including three main lineages: Lejeuneeae, Brachiolejeuneeae, and Symbiezidiae. Ahonen and Muona (2003) excluded Nipponolejeunea from Lejeuneaceae and moved it to Jubulaceae whereas the two controversial genera Bryopteris and Metzgeriopsis were proved to be genuine members of this family based on molecular evidence (Wilson et al., 2004). Many genera in Lejeuneaceae were reduced to subgeneric rank or synonymy by molecular studies, e.g., Metzgeriopsis (Gradstein et al., 2006), Cystolejeunea (Wilson et al., 2004), Dendrolejeunea (Sukkharak et al., 2011), Taxilejeunea and Leucolejeunea (Wilson et al., 2007a), and Oryzolejeunea (Ye et al., 2013).

\section{Molecular Studies}

Subfamily Ptychanthoideae and Lejeuneoideae can be distinguished by a set of morphological characters, i.e., Lejeuneoideae have underleaves either bifid or entire and 
usually 2-celled ventral merophytes in contrast to entire underleaves and at least 4celled ventral merophytes in Ptychanthoideae; Lejeuneoideae have an articulate seta (12+4 cell rows), erect capsule valves with 5-6 elaters per valve, capsule valve hinge horseshoe-, butterfly-, or broadly quadrate-shaped, not extending to the valve margin, whereas Ptychanthoideae have a non-articulate seta $(16+4$ cell rows), suberect to obliquely spreading capsule valves with 6-20 elaters per valve which are also fixed at the surface of the valve, and a rectangular valve hinge extending to the valve margin.

The subfamily Lejeuneoideae includes three tribes, Brachiolejeuneeae (8 genera), Symbiezidieae (1 genus) and Lejeuneeae (40 genera). Lejeuneeae, the largest tribe in Lejeuneaceae, is mainly characterized by usually bifid underleaves (rarely entire or lacking) with bistratose bases, segmented or homogeneous (Massula-type) oil bodies, occasional presence of ocelli, seta of 12 outer rows of cells, and the butterfly - or broadly quadrate-shaped valve hinge (Gradstein, 2013; Wilson et al., 2007a). Based on molecular and morphological evidence, Gradstein (2013) classified Lejeuneeae into eight subtribes, Cheilolejeuneinae (4 genera), Echinolejeuneinae (3 genera), Cyclolejeuneinae (3 genera), Lepidolejeuneinae (2 genera), Lejeuneinae (5 genera), Ceratolejeuneinae (2 genera), Drepanolejeuneinae (2 genera), and Cololejeuneinae (12 genera).

My studies focused on several critical genera in two subtribes, Cololejeuneinae and Lejeuneinae. Previous morphological and molecular studies of Lejeuneaceae (Gradstein et al., 2003; Wilson et al., 2007a) have recovered these two subtribes as robust monophyletic lineages, which contain the majority of the family diversity. Species within these two groups are usually highly specialized to an epiphytic living and grow in extreme habitats, such as leaf surfaces of vascular plants and twigs. Some species in these two groups can even grow in periodically submerged running waters as rheophytes (Gradstein and Reiner-Drehwald, 2007; Heinrichs et al., 2012e; ReinerDrehwald and Gradstein, 1995). However, few studies (Hartmann et al., 2006) have investigated genus level molecular phylogenies within Lejeuneeae genera. Considering widespread morphological homoplasy within Lejeuneeae and subsequent taxonomic confusions, it is necessary to apply molecular methods to study and test the systematic 
positions and biogeography of these genera in a phylogenetic context. In the following paragraphs, I will introduce the genera studied in my molecular studies.

\subsection{Diplasiolejeunea}

Diplasiolejeunea is a pantropical genus growing on living leaves, fine twigs, and smooth-barked trunks, usually in well-illuminated sites from sea level to $4150 \mathrm{~m}$. This genus is mainly characterized by one underleaf per leaf in combination with rather large but not sac-like leaf lobules (Zhu and So, 2001). Due to extensive morphological homoplasy, previous morphological systematic studies usually arrived at conflicting results (Grolle, 1966; Pócs, 2006; Pócs and Schäfer-Verwimp, 2006; Schäfer-Verwimp, 2004 \& 2006; Schäfer-Verwimp and Reiner-Drehwald, 2009; Tixier, 1985). The uncertainty regarding species circumscription has led to divergent estimates of global diversity, ranging from 35 (Schuster, 1980) to 70 Diplasiolejeunea species (SchäferVerwimp, 2006). Most Diplasiolejeunea species seem to have rather narrow distribution ranges, in contrast to the pantropical ranges of $D$. cavifolia Steph., D. cobrensis Steph. and D. rudolphiana Steph. (Grolle, 1995; Zhu and So, 2001). Hence, it would be necessary to test the species concept, as well as to carve out the distribution pattern of this genus and explore the possible reasons for its range formation. To this end, my comprehensive study on Diplasiolejeunea in Appendix 1 sampled 122 accessions covering the whole range of the genus, three genomic regions ( $c p$ rbcL and $t r n L-F$, nrITS), and six morphological and ecological characters. The recovered topology and ancestral area reconstructions show geographically separated clades as well as ecologically and altitudinally separated clades. My study supports a deep split into a Neotropical and a Paleotropical clade, the latter structured into Australasian, Asian and Afromadacascan lineages. Presented results confirm the ranges of two pantropical species (D. cavifolia, D. rudolphiana), provide evidence for dispersal from the Neotropics into the Paleotropics, indicate speciation along altitudinal gradients and demonstrate extensive morphological homoplasy. I propose a revised supraspecific classification of Diplasiolejeunea into a predominantly Paleotropical subgenus Physolejeunea and predominantly Neotropical subgenera Austrolejeuneopsis and Diplasiolejeunea, the former containing mainly epiphytic species, the latter mainly epiphylls. 


\subsection{Lejeunea}

Lejeunea Lib. is one of the most species rich and taxonomically complex genera of Lejeuneaceae. This genus is currently circumscribed by long-inserted leaves, divided or undivided underleaves, leaf lobules with an unreduced first tooth and a marginal hyaline papilla, small, segmented or homogeneous oil bodies, lack of ocelli, lejeuneoid innovations, unwinged female bracts and inflated perianths with 0-5 smooth or toothed wings. Lejeunea was first described by Libert (1820) to include only two species: Cololejeunea calcarea and Lejeunea cavifolia (Grolle, 1971). Adopting a broad genus concept, Gottsche et al. (1844-1847) described ca. 300 tropical species of Lejeunea. Spruce (1884) further grouped all the Lejeuneaceae elements into two genera, the monospecific genus Myriocolea and the speciose genus Lejeunea. Later on, Stephani (1898-1925) provided a global treatment of liverworts; his Species Hepaticarum included numerous new species, many of which were known only from single accessions, creating a multitude of synonyms. Most binomials in Lejeunea are now assigned to other genera or are reduced to synonyms. Reiner-Drehwald accepted 165 binominals out of 1749 Latin American Lejeunea names as effectively belonging to this genus (ReinerDrehwald, 1999). Revisions and updated checklists of Lejeunea for different regions have also been published, i.e., 12 species were recognized for Japan (Mizutani, 1961), 30 species for China (Piippo, 1990), 9 species for Europe (Grolle, 1983), 39 species for Sub-Saharan Africa (Wigginton and Grolle, 1996), 25 species for East African Islands (Grolle, 1995), 16 species for North America (Schuster, 1980), 12 species for southern South America (Solari, 1983), and 41 species for Brazil (Reiner-Drehwald, 2007). However, the exact number of Lejeunea species remains unclear due to a lack of comprehensive taxonomic studies (Gradstein et al., 2003) and scarcity of diagnostic morphological characters (Gradstein et al., 2003; Hartmann et al., 2006; Heinrichs et al., 2009; Reiner-Drehwald and Ilkiu-Borges, 2007; Renner et al., 2011; Schuster, 1983; Wiggington, 2004).

Meanwhile, subgenus circumscription is also a major problem in Lejeunea. Spruce (1884) described 39 subgenera in Lejeunea, of which the majority was later elevated to genus rank by Schiffner (1893) since Spruce's "Lejeunea" represents nearly the whole 
family Lejeuneaceae as it is now understood. Subsequent authors (Gradstein and Reiner-Drehwald, 2007; Grolle, 1984a \& 1984b \& 1995; Schuster, 1963) added further 13 subgenera to Lejeunea. Most of these subgenera, were not accepted by other workers (Reiner-Drehwald, 1999). Recent morphological and molecular studies indicated that many previously defined Lejeunea subgenera do not merit subgeneric status and were reduced to synonyms of Lejeunea, namely, subg. Apolejeunea and Hygrolejeunea (Schuster, 1980), Crossotolejeunea (Reiner-Drehwald and Goda, 2000), Inflatolejeunea and Macrolejeunea (Reiner-Drehwald and Schafer-Verwimp, 2008b), and Taxilejeunea (Wilson et al., 2007a). Subgenus Microlejeunea was treated as an independent genus by many recent authors (Ah-Peng and Bardat, 2011; Bischler et al., 1963; Grolle, 1995). By now, eight Lejeunea subgenera are provisionally accepted, Chaetolejeunea (Schuster, 1963), Heterolejeunea (Grolle, 1995), Nanolejeunea (Schuster, 1980), Neopotamolejeunea (Gradstein and Reiner-Drehwald, 2007), Otigoniolejeunea (Spruce, 1884), Pleurolejeunea (Schuster, 1963) and Sphaerocolea (Schuster, 1963). Subgenus Lejeunea was considered to be a polymorphic group including nine sections (Schuster 1957, 1980). A comprehensive study of Lejeunea would hopefully establish the species limits as well as an improved subgenus circumscription.

Compared to three pantropical species in Diplasiolejeunea, $25.6 \%(21 / 82)$ of the investigated Lejeunea species show disjunct ranges, many of these species span several continents. Molecular phylogenetic studies of this genus and subsequent ancestral area reconstruction would be crucial to recover the distribution pattern of Lejeunea, providing insights into the range formation of the genus. In Appendix 2, I produced a large Lejeunea phylogeny incorporating three genomic regions (nrITS, cp $r b c \mathrm{~L}$ and $t r n \mathrm{~L}-\mathrm{F}$ ) and 332 accessions covering the whole distribution range of the genus. My study recovered two major lineages differing in sexuality tendencies, which were subsequently assigned to two subgenera, subgenus Lejeunea and subgenus Crossotolejeunea. Nearly half of the species (25/54) with multiple accessions were resolved as para- or polyphyletic. Ancestral area reconstructions pointed to a Neotropical origin of Lejeunea and confirmed the previous hypothesis that the tropics are the cradle and museum of Lejeuneaceae diversity. 


\subsection{Microlejeunea}

Microlejeunea has been treated either as a genus (Ah-Peng and Bardat, 2011; Bischler et al., 1963; Grolle, 1995) or as a subgenus of Lejeunea (Schuster, 1980; Thiers, 1997). Both treatments seem consistent with the available phylogenies (Ahonen and Muona, 2003; Wilson et al., 2004) which placed Microlejeunea in a sister relationship to Lejeunea. Wilson et al. (2007a) also resolved the monospecific genus Pluvianthus and Harpalejeunea in a sister relationship to Lejeunea, whereas this study lacked representatives of Microlejeunea. Therefore, the systematic position of Pluvianthus is still in need of further investigations with a dense sampling of the related genera.

Morphologically, Microlejeunea is characterized by sinuose stems, presence of three medullary cells, perpendicular branching, large lobules being usually longer than wide, dimorphic lobules, small bifid underleaves, bracts being larger than the leaves and often shortly connate at their bases, male bracts being distinctly larger than the leaves (Bischler et al., 1962), a tendency to produce ocelli (Schuster, 1957), and the presence of lejeuneoid subgynoecial innovations (Grolle, 1995). Pluvianthus differs from Lejeunea by its rather large plant size, utriculiform leaves, laminar elaters, and capsule microanatomy (Schuster and Schäfer-Verwimp, 1995).

Harpalejeunea closely resembles Microlejeunea but has underleaves with diverging lobes, those of Microlejeunea being forward directed (Grolle and Reiner-Drehwald, 1999). The generic circumscription of Harpalejeunea is still subject to controversy. Grolle and Reiner-Drehwald (1999) separated Harpalejeunea by its lejeuneoid subgynoecial innovations from Drepanolejeunea with pycnolejeuneoid innovations. In contrast, Schuster (1980) considered Harpalejeunea filicuspis to be an element of Drepanolejeunea, despite the presence of lejeuneoid subgynoecial innovations. In Appendix 3 I tested the current genus concepts by including representatives of Harpalejeunea, Microlejeunea, Pluvianthus, and Drepanolejeunea in a three-marker dataset of Lejeuneeae. My study constantly placed Pluvianthus and three Harpalejeunea species within the Microlejeunea clade. Based on the molecular lineages recovered and a reinterpretation of morphological traits, the above four species were transferred to 
Microlejeunea. Microlejeunea and Harpalejeunea are accepted at genus level.

\subsection{Myriocolea}

Spruce (1884) accepted only two genera in the Lejeuneaceae, the monotypic Myriocolea with its single representative Myriocolea irrorata and the speciose genus Lejeunea with hundreds of species. This rheophytic genus Myriocolea differs from other Lejeuneaceae species by the exclusive presence of Radula-type branches, transversely inserted leaves without well delimited lobuli, presence of numerous antheridia per bract, and an extraordinary high number of clustered gynoecia (Gradstein et al., 2004; Thiers, 1983). The systematic position of Myriocolea is controversial. Schuster (1963) set up a new subfamily Myriocoleoideae to include Myriocolea and Cladocolea, a taxon treated as a synonym of Lejeuneoideae by Gradstein (1994). The latter treatment was also supported by cladistic analyses of morphological character states of Lejeuneaceae (Gradstein et al., 2003) where Myriocolea was resolved in an unsupported CololejeuneaTuyamaella clade. This relationship was also recovered by several molecular phylogenies based on one or two molecular markers (Gradstein et al., 2006; Wilson et al., 2004). Phylogenetic analyses of a comprehensive four molecular marker set of Lejeuneaceae consistently located Myriocolea in a clade with Macrocolura and Colura (Wilson et al., 2007a). However, lack of comprehensive sampling of Colura (three Colura species) hampered the discovery of the true relationships of Myriocolea. In Appendix 4, I present the results of phylogenetic analyses of a dataset comprising two chloroplast genome regions and one nuclear genome region and a comprehensive taxonomic sampling of Macrocolura, Myriocolea and Colura. Molecular phylogenetic analyses resolved Myriocolea within Colura.

\subsection{Sphaerolejeunea}

Sphaerolejeunea Herzog was set up for a single species, S. umbilicata Herzog and based on a single specimen collected by E.P. Killip in 1922 in the Andes of Colombia (Herzog, 1938). This epiphyllous species stands out by leaf lobes bordered by several

rows of hyaline cells, basally leafless gynoecial branches and perianths lacking both a beak and keels. These perianths hardly exceed the surrounding vegetative leaves 
(Herzog, 1938) and open in an umbilicus at their dorsal side (Reiner-Drehwald and Drehwald, 2002). In 2001 a second locality of Sphaerolejeunea umbilicata was discovered in the Andes of northern Peru (Reiner-Drehwald and Drehwald, 2002). The respective herbarium specimen allowed for a detailed morphological investigation of the species and the proposal of a close relationship of Sphaerolejeunea and Lejeunea (Reiner-Drehwald and Drehwald, 2002). In the framework of a molecular phylogenetic study of Lejeunea, three molecular markers of Sphaerolejeunea were sequenced and included in a large sequence alignment of Lejeuneaceae to clarify its systematic position (Appendix 5). Sphaerolejeunea was resolved within Lejeunea and transferred to this genus, as Lejeunea drehwaldii Heinrichs \& Schäfer-Verwimp.

\subsection{Bromeliophila}

Bromeliophila R.M. Schust. was established for Peltolejeunea natans Steph., a Brazilian endemic, growing exclusively in the tanks of Bromeliaceae (Schuster, 1994), with the lower parts of the shoots often submerged and only the upper parts above the water. Schuster (1994) pointed to close relationships of Bromeliophila and Lejeunea, a view shared by Gradstein (1997) who considered the generic status to be "critical". However, Gradstein described a second Neotropical species, Bromeliophila helenae Gradst. Earlier, Grolle (1985) transferred Peltolejeunea natans to Lejeunea, as Lejeunea natans (Steph.) Grolle. Recent molecular phylogenetic studies of Lejeuneaceae confirmed a general trend towards the acceptance of larger genera (Humphreys and Linder, 2009), especially merging small or monotypic genera into larger ones. A similar result was also expected for Bromeliophila since several authors proposed close relationships (Gradstein, 1997; Schuster, 1994) of Bromeliophila and Lejeunea based on their extensive morphological overlap or treated the generitype Peltolejeunea natans as an element of Lejeunea (Grolle, 1985). In Appendix 6, the systematic position of Bromeliophila is clarified in the framework of a comprehensive molecular phylogenetictaxonomic study of Lejeuneaceae. This molecular study supports a sister relationship of Bromeliophila and Prionolejeunea, which is in turn sister to Cyclolejeunea. 


\section{Discussion}

Molecular phylogenetic studies in several genera of Lejeuneeae allow deeper insights into this taxonomically complex group. The phylogeny of the pantropical genus Diplasiolejeunea shows ecologically as well as geographically separated lineages. Based on the recovered topology and the distribution of subgenus type species, three major clades were formally named, leading to the acceptance of a pantropical subg. Physolejeunea, a predominantly neotropical epiphytic subg. Austrolejeunopsis, and a predominantly neotropical epiphyllous subg. Diplasiolejeunea. Ancestral area reconstructions of Diplasiolejeunea support dispersal scenarios in shaping current distribution patterns, which is also corroborated by the Lejeunea biogeography reconstruction with $25.6 \%$ disjunct species (21/82). The Lejeunea phylogeny contradicts with previous subgenus classification and many existing species concepts. Based on the presence of type species in each clade, we assign subgenus Lejeunea to the major clade I and subgenus Crossotolejeunea to the major clade II. These two major clades differ in sexuality tendencies, clade I shows a tendency of monoecy whereas clade II shows more often dioecy. Nearly half of the species (44.6\%) with multiple accessions are para- or polyphyletic, of these, monoecious taxa contribute to $66.7 \%$, diocious taxa take $33.3 \%$. Majority (70.4\%) of diocious taxa, in contrast to $42.9 \%$ in monecious taxa, form monophyletic lineages. Monecious taxa (27.3\%) as well as diocious taxa $(23.7 \%)$ show disjunct distribution range.

The presented studies clarified the systematic positions of several controversial taxa, based on molecular phylogenies and a reinterpretation of morphological characters. Monotypic Myriocolea is transferred to Colura, monotypic Pluvianthus and three Harpalejeunea species are transferred to Microlejeunea, monotypic Sphaerolejeunea is transferred to Lejeunea, adding to the growing evidence that many small genera nest in larger ones. However, Bromeliophila breaks the rule. Bromeliophila was previously believed to be an element of Lejeunea based on its extensive morphological overlap with Lejeunea whereas molecular studies unexpectedly placed Bromeliophila in a sister relationship to Prionolejeunea. 


\subsection{Biogeography}

The clear geographic pattern shown in Diplasiolejeunea in Appendix 1 is surprising with regard to the high dispersal ability of spore plants (van Zanten, 1978; Vanderpoorten et al., 2010; Wolf et al., 2001), and has not yet been documented for any other liverwort genus. Diplasiolejeunea splits into pantropical subgenus Physolejeunea, neotropical epiphytic subgenus Austrolejeuneopsis, and neotropical epiphyllous subgenus Diplasiolejeunea. Epiphytic subgenus Austrolejeuneopsis occurs in high altitudinal Andean cloud forests whereas epiphyllous subgenus Diplasiolejeunea occurs in lowland forests and low montane regions. This strong correlation could point to the rise of Andes' influence on the assembly of Diplasiolejeunea diversity, possibly by stimulating the diversification of the subgenus Austrolejeuneopsis, perhaps by providing new habitats. The clear geographical pattern shown in Diplasiolejeunea could be indicative of Gondwanan vicariance, however, divergence time estimates suggest an origin of Diplasiolejeunea in the Oligocene (Wilson et al., 2007b), posterior to the Mesozoic breakup of the Southern landmass. Therefore, a combination of frequent short distance dispersal, occasional long distance dispersal, extinction and recolonization, as well as niche conservatism was invoked to explain the observed pattern.

The biogeographical pattern recovered in Lejeunea in Appendix 2 is not so distinct, compared with that observed in Diplasiolejeunea. Both main clades of Lejeunea show a more even representation of putative regions of endemism, indicating that long distance dispersal is more frequent in Lejeunea than in Diplasiolejeunea as long as we assume similar ages for both genera. Both S-diva and Mesquite reconstructions indicated that Lejeunea originated and initially diversified in the Neotropics with subsequent dispersal into other tropical as well as temperate regions. A few temperate lineages nested within tropical clades. This pattern appears to be consistent with the role of the tropics as a cradle and museum of diversity, and mirrors observations for the whole family Lejeuneaceae.

In the systematic examination of Myriocolea, 17 Colura accessions show a geographic structure into Asian-Australasian, Neotropical and African lineages. However, whether 
this pattern would sustain or not when more accessions are included, is still left to future studies.

\subsection{Cryptic speciation}

An important question in bryophyte systematics is whether disjunctive geographical distributions, morphological uniformity, and long evolutionary history, reflect evolutionary stasis or if morphological uniformity masks underlying genetic complexity (Shaw et al., 2002). Traditional hypotheses regarding liverworts as unmoving, unchanging sphinxes of the past (Crum, 1972) is frequently challenged. Increasing molecular phylogenetic studies in bryophytes reveal the existence of numerous cryptic biological species that have accumulated genetic divergence without concordant morphological disparities. Morphologically cryptic biological entities have been observed in the genera Conocephalum (Odrzykoski and Szweykowski, 1991), Frullania (Ramaiya et al., 2010), Leptoscyphus (Vanderpoorten et al., 2010), Marchesinia (Heinrichs et al., 2009), Metzgeria (Fuselier et al., 2009), Pellia (Odrzykoski et al., 1996), Ptilidium (Kreier et al., 2010), and are also present in Diplasiolejeunea and Lejeunea. For example, the pantropical species $D$. cavifolia is regarded to be a somewhat variable species (SchäferVerwimp and Reiner-Drehwald, 2009) including forms with strongly T-shaped lobule teeth (earlier recognized as $D$. matoubae and $D$. zacatepecensis) as well as forms without such teeth. This species forms a robust lineage with two main clades; however, the different morphotypes are present in both. The two clades occur sympatrically in the West Indies, and can thus neither be separated using geographical nor morphological evidence. Many cryptic speciations occur along altitudinal gradients, i.e., D. pauckertii, $L$. reflexistipula. L. reflexistipula is an Andean species, characterized by entire incubous underleaves and relatively large size. Molecular studies resolved this species into two robust clades, one from lower altitude, the other from higher altitude including two accessions of $L$. reflexistipula var. costaricensis and three accessions of $L$. reflexistipula. The two clades cannot be separated by morphological evidence, indicating cryptic speciation along atlitudinal gradients. 


\subsection{Taxa relocation}

Liverworts are a group of simple and primitive plants with a long evolutionary history. Traditional taxonomy on this group usually relied mainly on morphological descriptions and observations. The resulting classification scheme was often problematic due to extensive morphological homoplasy, especially in the family Lejeuneaceae. Recent molecular studies have greatly improved the classification of liverworts. Based on the recovered lineages and reinterpretation of morphological characters, numerous smaller genera were incorporated into larger ones.

My phylogenetic study in Appendix 3 resolved a monotypic genus Pluvianthus and three Harpalejeunea species, namely $H$. filicuspis, $H$. fischeri, and $H$. latitans in a clade with several species of Microlejeunea including the generitype $M$. africana. Morphologically these species shared with Mircrolejeunea three medullary cells, a tendency to produce ocelli and forwardly directed underleaf lobes. Typical Harpalejeunea are similar to Microlejeunea in many aspects, but differ from Microlejeunea by their widely diverging underleaf lobes (Grolle and Reiner-Drehwald, 1999). Hence a transfer of the above three species of Harpalejeunea to Microlejeunea is justified both by molecular and morphological data.

Molecular studies in Appendix 4 resolved Myriocolea irrorata in the Colura sect. Colura clade. Morphologically, these two genera share one underleaf per leaf (also present in Diplasiolejeunea and Macrocolura) instead of one underleaf per leaf pair as presented in the rest Lejeuneaceae (Gradstein et al., 2003). Myriocolea irrorata differs from Colura by lack of sack-like lobules, whereas a tendency to lose lobules is also seen in Colura sect. Heterophyllum and Colura corynephora. Therefore, Myriocolea irrorata is transferred to Colura. The rheophytic, nutrient-rich habitat may explain the untypical leaf development of Colura irrorata because a structure for water storage or zoophagy is not needed in such an environment. Rheophytes from different taxonomic groups exhibit a parallel development, because running waters and regular flooding shape them into flood resistant plants (Van Steenis, 1981), e.g., Myriocoleopsis and Myriocolea (Gradstein et al., 2004), Lejeunea subg. Neopotamolejeunea (Gradstein and Reiner- 
Drehwald, 2007), and Cololejeunea stotleriana (Gradstein et al., 2011).

Reiner-Drehwald and Drehwald (2002) pointed out that Sphaerolejeunea may represent the sister group of Lejeunea. Despite many similarities, Sphaerolejeunea differs from Lejeuna by the development of a second lobule tooth, gynoecial branches without leaves at the base, beakless perianths being umbilicate on the dorsal side and valves with five marginal elaters lacking thickenings. However, the molecular studies in Appendix $\mathbf{5}$ indicate that Sphaerolejeunea is nested in Lejeunea and that its morphological peculiarities represent autapomorphies of a Lejeunea species.

Although there is a general trend towards merging smaller genera into larger ones, a few exceptions break the rule. Morphologically, Bromeliophila stands out by its 5-keeled perianth with each keel doubled winged, and entire leaf margin in contrast to 2-keeled perianth and denticulate leaf margin in Prionolejeunea and Cyclolejeunea. Phylogenetic analyses in Appendix 6 confirmed the monophyly of Bromeliophila and provided evidence for a sister relationship of Bromeliophila and Prionolejeunea; this clade is in turn sister to Cyclolejeunea. Bromeliophila and Prionolejeunea share Lejeunea type gynoecial innovations in contrast to pycnolejeunoid gynoecial innovations in Cyclolejeunea. Based on the molecular topology and morphological evidence, Cyclolejeunea is subdivided in subgenus Cyclolejeunea with ocelli and rounded gemmae, monospecific subgenus Hyalolejeunea without ocelli, and monospecific subgenus Nephrolejeunea with elongate gemmae and ocelli.

\subsection{Future Prospects}

Previous molecular and morphological studies divided Lejeuneaceae into 2 subfamilies and 4 lineages but deep nodes remained unsupported. Current phylogenetic study of several genera within subfamily Lejeuneoideae clarified their circumscription whereas the inter-relationships among many problematic taxa remains unclear, i.e. $D$. pauckertii group, $D$. pellucida-caribea complex, L. flava complex, L. anisophylla complex. Future studies incorporating molecular markers (Chang and Graham, 2011; Qiu et al., 2006), cytological studies, spore ultra-structure studies (von Konrat et al., 2012), geometric morphometric analysis (Renner, 2012) and phylogenomic studies (Timme et 
al., 2012) may attain better phylogenetic resolution to these problems.

Recent biogeographical studies (Feldberg et al., 2007; Feldberg et al., 2010; Hartmann et al., 2006; Heinrichs et al., 2006) on leafy liverworts unanimously pointed to dispersal scenarios in shaping current distribution ranges. My studies on Lejeunea and Diplasiolejeunea also confirm this pattern. However, the discussion of the impact of geological events cannot be detailed without reasonable time constraints. So far, only several dating studies (Cooper et al., 2012b; Hartmann et al., 2006; Heinrichs et al., 2007; Wilson et al., 2007b) have been conducted in leafy liverworts. These studies all point to the origin of many genera of leafy liverworts in the Cretaceous or Cenozoic. Future dating studies incorporating more fossil records and dense taxon sampling will be essential to illustrate the general biogeographical pattern of Lejeuneaceae and the impacts of geological events.

Plant geographical pattern is affected by sexual system, spore dispersal ability and plant ecological fitness. Thus future studies in these areas will help to better illustrate the dynamics of plant genetic structure. To achieve this point, population studies at species level (Bączkiewicz, 2013), spore germination studies, and hybrid speciation studies, would be of prime importance. Hybridization (Shaw, 1998) and polyploidy in bryophytes is drawing increasingly attention (Self, 2002; Shaw and Goffinet, 2000). Hybridization is an important type of evolution (Natcheva and Cronberg, 2004), which might be the reason for the lack of support in some nodes. However, hybridization in leafy liverworts has only been demonstrated in European Porella $\times$ baueri, an allopolyploid derivative of P. cordaeana and P. platyphylla (Boisselierdubayle and Bischler, 1994). Heinrichs et al. (2011) also suggest an ancient hybrid origin of $P$. platyphylloidea from crossings of $P$. cordaeana and $P$. platyphylla s.str., inferred from the incongruent signals of chloroplast and nuclear markers.

\section{References}

Ah-Peng, C. and Bardat, J. (2011). Microlejeunea strasbergii sp. nov. (Lejeuneaceae) from Réunion Island (Mascarenes). The Bryologist 114, 668-673. 
Ahonen, I. and Muona, J. (2003). Inferring the phylogeny of the Lejeuneaceae (Jungermanniopsida): A first appraisal of molecular data. The Bryologist 106, 297-308.

Bączkiewicz, A. (2013). Genetic diversity of leafy liverwort species (Jungermanniidae, Marchantiophyta) in Poland: regional genetic differentiation of leafy liverworts. Biodiversity: Research and Conservation 27, 55-76.

Beckert, S., Steinhauser, S., Muhle, H. and Knoop, V. (1999). A molecular phylogeny of bryophytes based on nucleotide sequences of the mitochondrial nad5 gene. Plant Syst. Evol. 218, 179-192.

Bischler, H., Bonner, C.E.B. and Miller, H.A. (1963). Studies in Lejeuneaceae, VI. The genus Microlejeunea Steph. in Central and South America. Nova Hedwigia 5, 359-411.

Bischler, H., Miller, H.E. and Bonner, C.E.B. (1962). Studies in Lejeuneaceae IV: The typification of the genus Microlejeunea. Nova Hedwigia 4, 173-187.

Boisselier-Dubayle, M.C., Lambourdiere, J. and Bischler, H. (2002). Molecular phylogenies support multiple morphological reductions in the liverwort subclass Marchantiidae (Bryophyta). Mol. Phylogenet. Evol. 24, 66-77.

Boisselier-Dubayle, M.C. and Bischler, H. (1994). A combination of molecular and morphological characters for delimitation of taxa in European Porella. J. Bryol. 18, 111.

Capesius, I. (1995). A molecular phylogeny of bryophytes based on the nuclear encoded 18S rRNA genes. J. Plant Physiol. 146, 59-63.

Capesius, I. and Bopp, M. (1997). New classification of liverworts based on molecular and morphological data. Plant Syst. Evol. 207, 87-97.

Chang, Y. and Graham, S.W. (2011). Inferring the higher-order phylogeny of mosses (Bryophyta) and relatives using a large, multigene plastid data set. Am. J. Bot. 98, 839-849. 
Cooper, E.D., Henwood, M.J. and Brown, E.A. (2012a). A molecular phylogeny of the Lepidozia generic complex supports re-circumscription of the Lepidozioideae. Mol. Phylogenet. Evol. 65, 10-22.

Cooper, E.D., Henwood, M.J. and Brown, E.A. (2012b). Are the liverworts really that old? Cretaceous origins and Cenozoic diversifications in Lepidoziaceae reflect a recurrent theme in liverwort evolution. Biol. J. Linn. Soc. 107, 425-441.

Cooper, E.D., Shaw, A.J., Shaw, B., Henwood, M.J., Heslewood, M.M. and Brown, E.A. (2011). A multi-locus molecular phylogeny of the Lepidoziaceae: laying the foundations for a stable classification. Mol. Phylogenet. Evol. 59, 489-509.

Cornelissen, J.H.C. and Ter Steege, H. (1989). Distribution and ecology of epiphytic bryophytes and lichens in dry evergreen forest of Guyana. J. Trop. Ecol. 5, 131-150.

Crandall-Stotler, B. and Stotler, R.E. (2000). Morphology and classification of the Marchantiophyta. Reino Unido, Cambridge University Press.

Crandall-Stotler, B., Stotler, R.E. and Long, D.G. (2009). Phylogeny and classification of the Marchantiophyta. Edinb. J. Bot. 66, 155-198.

Crandall-Stotler, B.J., Forrest, L.L. and Stotler, R.E. (2005). Evolutionary trends in the simple thalloid liverworts (Marchantiophyta, Jungermanniopsida subclass Metzgeriidae). Taxon 54, 299-316.

Cronberg, N. (2002). Colonization dynamics of the clonal moss Hylocomium splendens on islands in a Baltic land uplift area: reproduction, genet distribution and genetic variation. J. Ecol. 90, 925-935.

Crum, H.A. (1972). The geographic origins of the mosses of North America's Eastern deciduous forest. J. Hattori Bot. Lab. 35, 269-298.

Cusimano, N. and Renner, S.S. (2010). Slowdowns in diversification rates from real phylogenies may not be real. Syst. Biol. 59, 458-464. 
Davis, C.C., Bell, C.D., Mathews, S. and Donoghue, M.J. (2002). Laurasian migration explains Gondwanan disjunctions: evidence from Malpighiaceae. Proc. Natl. Acad. Sci. U.S.A. 99, 6833-6837.

Davis, E.C. (2004). A molecular phylogeny of leafy liverworts (Jungermanniidae: Marchantiophyta). Monogr. Syst. Bot. Missouri Bot. Gard. 98, 61-86.

Devos, N. and Vanderpoorten, A. (2009). Range disjunctions, speciation, and morphological transformation rates in the liverwort genus Leptoscyphus. Evolution 63, 779-792.

Duff, R.J. and Nickrent, D.L. (1999). Phylogenetic relationships of land plants using mitochondrial small-subunit rDNA sequences. Am. J. Bot. 86, 372-386.

Evans, A.W. (1935). The anatomy of the stem in the Lejeuneae. Bull. Torrey Bot. Club. 62, 259-280.

Feldberg, K. and Heinrichs, J. (2006). A taxonomic revision of Herbertus (Jungermanniidae : Herbertaceae) in the Neotropics based on nuclear and chloroplast DNA and morphology. Bot. J. Linn. Soc. 151, 309-332.

Feldberg, K., Hentschel, J., Wilson, R., Rycroft, D.S., Glenny, D. and Heinrichs, J. (2007). Phylogenetic biogeography of the leafy liverwort Herbertus (Jungermanniales, Herbertaceae) based on nuclear and chloroplast DNA sequence data: correlation between genetic variation and geographical distribution. J. Biogeogr. 34, 688-698.

Feldberg, K., Vana, J., Long, D.G., Shaw, A.J., Hentschel, J. and Heinrichs, J. (2010). A phylogeny of Adelanthaceae (Jungermanniales, Marchantiophyta) based on nuclear and chloroplast DNA markers, with comments on classification, cryptic speciation and biogeography. Mol. Phylogenet. Evol. 55, 293-304.

Fiz-Palacios, O., Schneider, H., Heinrichs, J. and Savolainen, V. (2011). Diversification of land plants: insights from a family-level phylogenetic analysis. BMC Evol. Biol. 11. 
Forrest, L.L. and Crandall-Stotler, B.J. (2004). A phylogeny of the simple thalloid liverworts (Jungermanniopsida, Metzgeriidae) as inferred from five chloroplast genes. Monogr. Syst. Bot. Missouri Bot. Gard. 98, 119-140.

Forrest, L.L. and Crandall-Stotler, B.J. (2005). Progress towards a robust phylogeny for the liverworts, with particular focus on the simple thalloids. J. Hattori Bot. Lab., 127159.

Forrest, L.L., Davis, E.C., Long, D.G., Crandall-Stotler, B.J., Clark, A. and Hollingsworth, M.L. (2006). Unraveling the evolutionary history of the liverworts (Marchantiophyta): multiple taxa, genomes and analyses. The Bryologist 109, 303-334.

Frahm, J.P. (2000). Bryophytes. Ecol. Stud. 146, 91-102.

Frahm, J.P. (2004). New frontiers in bryology and lichenology - Recent developments of commercial products from bryophytes. The Bryologist 107, 277-283.

Fuselier, L., Davison, P.G., Clements, M., Shaw, B., Devos, N., Heinrichs, J., Hentschel, J., Sabovljevic, M., Szövenyi, P., Schütte, S., Hofbauer, W. and Shaw, A.J. (2009). Phylogeographic analyses reveal distinct lineages of Metzgeria furcata and $M$. conjugata (Metzgeriaceae) in Europe and North America. Biol. J. Linn. Soc. 98, 745756.

Fuselier, L.C., Shaw, B., Engel, J.J., von Konrat, M., Costa, D.P., Devos, N. and Shaw, A.J. (2011). The status and phylogeography of the liverwort genus Apometzgeria Kuwah. (Metzgeriaceae). The Bryologist 114, 92-101.

Garbary, D.J., Renzaglia, K.S. and Duckett, J.G. (1993). The phylogeny of land plants - a cladistic-analysis based on male gametogenesis. Plant Syst. Evol. 188, 237-269.

Goremykin, V.V. and Hellwig, F.H. (2005). Evidence for the most basal split in land plants dividing bryophyte and tracheophyte lineages. Plant Syst. Evol. 255, 119-119.

Gottsche, C.M., Lindenberg, J.B.G. and Nees ab Esenbeck, C.G. (1844-1847). Synopsis Hepaticarum, I-XXVI, 1-834. Hamburg. 
Gradstein, S.R. (1994). Lejeuneaceae: Ptychantheae, Brachiolejeuneae. Fl. Neotrop. Monogr. 62, 1-217.

Gradstein, S.R. (1997). The taxonomic diversity of epiphyllous bryophytes. Abstr. Bot. 21, $15-19$.

Gradstein, S.R. (2013). A classification of Lejeuneaceae (Marchantiophyta) based on molecular and morphological evidence. Phytotaxa 100, 6-20.

Gradstein, S.R., Churchill, S.P. and Salazar-Allen, N. (2001). Guide to the bryophytes of tropical America, New York Botanical Garden Press.

Gradstein, S.R., Ilkiu-Borges, A.L. and Vanderpoorten, A. (2011). Habitat specialization triggers the evolution of unusual morphologies - the case of Cololejeunea stotleriana sp. nov. from Ecuador. The Bryologist 114, 9-22.

Gradstein, S.R. and Reiner-Drehwald, M.E. (2007). The status of Neopotamolejeunea (Lejeuneaceae) and description of a new species from Ecuador and southern Brazil. Syst. Biol. 32, 487-492.

Gradstein, S.R., Reiner-Drehwald, M.E. and Jost, L. (2004). The systematic position and distribution of Myriocolea irrorata (Lejeuneaceae), an endangered liverwort of the ecuadorian andes. J. Hattori Bot. Lab., 235-248.

Gradstein, S.R., Reiner-Drehwald, M.E. and Schneider, H. (2003). A phylogenetic analysis of the genera of Lejeuneaceae (Hepaticae). Biol. J. Linn. Soc. 143, 391-410.

Gradstein, S.R., Wilson, R., Ilkiu-Borges, A.L. and Heinrichs, J. (2006). Phylogenetic relationships and neotenic evolution of Metzgeriopsis (Lejeuneaceae) based on chloroplast DNA sequences and morphology. Biol. J. Linn. Soc. 151, 293-308.

Grolle, R. (1966). Über Diplasiolejeunea in Asien. Feddes Repert 73, 78-89.

Grolle, R. (1971). Miscellanea hepaticologica 111-120. Trans. Brit. Bryol. Soc. 6, 258265. 
Grolle, R. (1983). Hepatics of Europe including Azores: an annotated list of species, with synonyms from recent literature. J. Bryol 12, 403-459.

Grolle, R. (1984a). Zur kenntnis der Lejeuneoideae in Cuba (1): Cyclolejeunea. Wiss. Z. Friedrich-Schiller-Univ.Jena, Math. Naturwiss. Reihe 33, 759-764.

Grolle, R. (1984b). Miscellanea hepaticologica 221-230. J. Hattori Bot. Lab. 55, 501-511.

Grolle, R. (1985). Miscellanea Hepaticologia 231-240. J. Hattori Bot. Lab. 58, 197-202.

Grolle, R. (1995). The Hepaticae and Anthocerotae of the East African Islands. An annotated catalogue. Bryophyt. Biblioth. 48, 1-178.

Grolle, R. and Reiner-Drehwald, M.E. (1999). Review of the genus Harpalejeunea (Lejeuneaceae) including the description of $H$. grandis, a new species from the páramos of Colombia. J. Bryol. 21, 31-45.

Groth-Malonek, M. and Knoop, V. (2005). Bryophytes and other basal land plants: the mitochondrial perspective. Taxon 54, 293-297.

Grundmann, M., Ansell, S.W., Russell, S.J., Koch, M.A. and Vogel, J.C. (2007). Genetic structure of the widespread and common Mediterranean bryophyte Pleurochaete squarrosa (Brid.) Lindb. (Pottiaceae) - Evidence from nuclear and plastidic DNA sequence variation and allozymes. Mol. Ecol. 16, 709-722.

Guo, C.Q., Edwards, D., Wu, P.C., Duckett, J.G., Hueber, F.M. and Li, C.S. (2012). Riccardiothallus devonicus gen. et sp nov., the earliest simple thalloid liverwort from the Lower Devonian of Yunnan, China. Rev. Palaeobot. Palynol. 176, 35-40.

Hartmann, F.A., Wilson, R., Gradstein, S.R., Schneider, H. and Heinrichs, J. (2006). Testing hypotheses on species delimitations and disjunctions in the liverwort Bryopteris (Jungermanniopsida: Lejeuneaceae). Int. J. Plant. Sci. 167, 1205-1214.

He-Nygren, X., Juslen, A., Ahonen, I., Glenny, D. and Piippo, S. (2006). Illuminating the evolutionary history of liverworts (Marchantiophyta) - Towards a natural classification. Cladistics 22, 1-31. 
Heinrichs, J., Bombosch, A., Feldberg, K., Kreier, H.P., Hentschel, J., Eckstein, J., Long, D., Zhu, R.L., Schafer-Verwimp, A., Schmidt, A.R., Shaw, B., Shaw, A.J. and Vana, J. (2012c). A phylogeny of the northern temperate leafy liverwort genus Scapania (Scapaniaceae, Jungermanniales). Mol. Phylogenet. Evol. 62, 973-985.

Heinrichs, J., Dong, S.S., Yu, Y., Schafer-Verwimp, A., Pocs, T., Feldberg, K., Hentschel, J., Schmidt, A.R. and Schneider, H. (2012e). A 150 year-old mystery solved: transfer of the rheophytic endemic liverwort Myriocolea irrorata to Colura. Phytotaxa 66, 55-64.

Heinrichs, J., Gradstein, S.R., Wilson, R. and Schneider, H. (2005a). Towards a natural classification of liverworts (Marchantiophyta) based on the chloroplast gene $r b c L$. Cryptog. Bryol. 26, 131-150.

Heinrichs, J., Groth, H., Lindner, M., Renker, C., Pocs, T. and Proschold, T. (2004). Intercontinental distribution of Plagiochila corrugata (Plagiochilaceae, Hepaticae) inferred from nrDNA ITS sequences and morphology. Biol. J. Linn. Soc. 146, 469-481.

Heinrichs, J., Hentschel, J., Bombosch, A., Fiebig, A., Reise, J., Edelmann, M., Kreier, H.P., Schafer-Verwimp, A., Caspari, S., Schmidt, A.R., Zhu, R.L., von Konrat, M., Shaw, B. and Shaw, A.J. (2010). One species or at least eight? Delimitation and distribution of Frullania tamarisci (L.) Dumort. s. I. (Jungermanniopsida, Porellales) inferred from nuclear and chloroplast DNA markers. Mol. Phylogenet. Evol. 56, 11051114.

Heinrichs, J., Hentschel, J., Wilson, R., Feldberg, K. and Schneider, H. (2007). Evolution of leafy liverworts (Jungermanniidae, Marchantiophyta): estimating divergence times from chloroplast DNA sequences using penalized likelihood with integrated fossil evidence. Taxon 56, 31-44.

Heinrichs, J., Klugmann, F., Hentschel, J. and Schneider, H. (2009). DNA taxonomy, cryptic speciation and diversification of the Neotropical-African liverwort, Marchesinia brachiata (Lejeuneaceae, Porellales). Mol. Phylogenet. Evol. 53, 113-121.

Heinrichs, J., Kreier, H.P., Feldberg, K., Schmidt, A.R., Zhu, R.L., Shaw, B., Shaw, A.J. and Wissemann, V. (2011). Formalizing morphologically cryptic biological entities: new 
insights from DNA taxonomy, hybridization, and biogeography in the leafy liverwort Porella Platyphylla (Jungermanniopsida, Porellales). Am. J. Bot. 98, 1252-1262.

Heinrichs, J., Lindner, M., Gradstein, S.R., Groth, H., Buchbender, V., Solga, A. and Fischer, E. (2005b). Origin and subdivision of Plagiochila (Jungermanniidae: Plagiochilaceae) in tropical Africa based on evidence from nuclear and chloroplast DNA sequences and morphology. Taxon 54, 317-333.

Heinrichs, J., Lindner, M., Groth, H., Hentschel, J., Feldberg, K., Renker, C., Engel, J.J., von Konrat, M., Long, D.G. and Schneider, H. (2006). Goodbye or welcome Gondwana? insights into the phylogenetic biogeography of the leafy liverwort Plagiochila with a description of Proskauera gen. nov (Plagiochilaceae, Jungermanniales). Plant Syst. Evol. 258, 227-250.

Heinrichs, J., Reiner-Drehwald, M.E., Feldberg, K., von Konrat, M., Hentschel, J., Vana, J., Grimaldi, D.A., Nascimbene, P.C. and Schmidt, A.R. (2012a). The leafy liverwort Frullania (Jungermanniopsida) in the Cretaceous amber forest of Myanmar. Rev. Palaeobot. Palynol. 169, 21-28.

Hentschel, J., von Konrat, M.J., Pocs, T., Schafer-Verwimp, A., Shaw, A.J., Schneide, H. and Heinrichs, J. (2009). Molecular insights into the phylogeny and subgeneric classification of Frullania Raddi (Frullaniaceae, Porellales). Mol. Phylogenet. Evol. 52, 142-156.

Hentschel, J., Zhu, R.L., Long, D.G., Davison, P.G., Schneider, H., Gradstein, S.R. and HeinrichS, J. (2007b). A phylogeny of Porella (Porellaceae, Jungermanniopsida) based on nuclear and chloroplast DNA sequences. Mol. Phylogenet. Evol. 45, 693705.

Hernick, L.V., Landing, E. and Bartowski, K.E. (2008). Earth's oldest liverworts Metzgeriothallus sharonae sp. nov. from the Middle Devonian (Givetian) of eastern New York, USA. Rev. Palaeobot. Palynol. 148, 154-162.

Herzog, T. (1938). Sphaerolejeunea, eine neue gattung der Lejeuneaceae Schizostipae. Annales Bryologici 11, 86-89. 
Herzog, T. (1957). Naturliche einteilung der familie [Lejeuneaceae]. Leipzig, 3rd ed.

Humphreys, A.M. and Linder, H.P. (2009). Concept versus data in delimitation of plant genera. Taxon 58, 1054-1074.

Karol, K.G., McCourt, R.M., Cimino, M.T. and Delwiche, C.F. (2001). The closest living relatives of land plants. Science 294, 2351-2353.

Kato, M. and Akiyama, H. (2005). Interpolation hypothesis for origin of the vegetative sporophyte of land plants. Taxon 54, 443-450.

Kelch, D.G., Driskell, A. and Mishler, B.D. (2004). Inferring phylogeny using genomic characters: a case study using land plant plastomes. Monogr. Syst. Bot. Mo. Bot. Gard., 3-12.

Knoop, V. (2010). Looking for sense in the nonsense: a short review of non-coding organellar DNA elucidating the phylogeny of bryophytes. Trop. Bryol., 51-60.

Kreier, H.P., Feldberg, K., Mahr, F., Bombosch, A., Schmidt, A.R., Zhu, R.L., von Konrat, M., Shaw, B., Shaw, A.J. and Heinrichs, J. (2010). Phylogeny of the leafy liverwort Ptilidium: cryptic speciation and shared haplotypes between the Northern and Southern Hemispheres. Mol. Phylogenet. Evol. 57, 1260-1267.

Laurin-Lemay, S., Brinkmann, H. and Philippe, H. (2012). Origin of land plants revisited in the light of sequence contamination and missing data. Curr. Biol. 22, R593-R594.

Lewis, L.A., Mishler, B.D. and Vilgalys, R. (1997). Phylogenetic relationships of the liverworts (Hepaticae), a basal embryophyte lineage, inferred from nucleotide sequence data of the chloroplast gene rbcL. Mol. Phylogenet. Evol. 7, 377-393.

Libert, M. (1820). Sur un genre nouveau d'Hepatiques, Lejeunia. Annales Gen. Sci. Phys. 6, 372-374.

Ligrone, R., Duckett, J.G. and Renzaglia, K.S. (2012). The origin of the sporophyte shoot in land plants: a bryological perspective. Ann. Bot. 110, 935-941. 
Long, D.G. (2006). New higher taxa of complex thalloid liverworts (MarchantiophytaMarchantiopsida). Edinburgh J. Bot. 63, 257-262.

Magill, R.E. (2010). Moss diversity: new look at old numbers. Phytotaxa 9, 167-174.

Mizutani, M. (1961). A revision of Japanese Lejeuneaceae. J. Hattori Bot. Lab. 24, 115302.

Mizutani, M. (1985). Subfamilies of Lejeuneaceae. Proc. Bryol. Soc. Japan 4, 3-4.

Natcheva, R. and Cronberg, N. (2004). What do we know about hybridization among bryophytes in nature? Can. J. Bot. 82, 1687-1704.

Nishiyama, T. and Kato, M. (1999). Molecular phylogenetic analysis among bryophytes and tracheophytes based on combined data of plastid coded genes and the 18S rRNA gene. Mol. Biol. Evol. 16, 1027-1036.

Nishiyama, T., Wolf, P.G., Kugita, M., Sinclair, R.B., Sugita, M., Sugiura, C., Wakasugi, T., Yamada, K., Yoshinaga, K., Yamaguchi, K., Ueda, K. and Hasebe, M. (2004). Chloroplast phylogeny indicates that bryophytes are monophyletic. Mol. Biol. Evol. 21, 1813-1819.

Odrzykoski, I.J., Chudzinska, E. and Szweykowski, J. (1996). The hybrid origin of the polyploid liverwort Pellia borealis. Genetica 98, 75-86

Odrzykoski, I.J. and Szweykowski, J. (1991). Genetic differentiation without concordant morphological divergence in the thallose liverwort Conocephalum conicum. Plant Syst. Evol. 178, 135-152.

Oostendorp, C. (1987). The bryophytes of the Paleozoic and Mesozoic. Bryophyt. Bibl. 34, 5-112.

Pócs, T. (2006). New or little-known epiphyllous bryophytes, X. On two Neotropical Diplasiolejeunea species. The Bryologist 109, 408-414. 
Pócs, T. and Schäfer-Verwimp, A. (2006). East African bryophytes, XXIII. Three new species of Diplasiolejeunea (Lejeuneaceae, Jungermanniopsida) from Madagascar. Cryptog. Bryol. 27, 439-452.

Patsch, R., Hentschel, J., Linares-Palomino, R., Zhu, R.L. and Heinrichs, J. (2010). Diversification and taxonomy of the liverwort Jubula Dumort. (Jungermanniopsida: Porellales) inferred from nuclear and chloroplast DNA sequences. Syst. Bot. 35, 6-12.

Pfeiffer, T. (2000). Molecular relationship of Hymenophyton species (Metzgeriidae, Hepaticophytina) in New Zealand and Tasmania. Studies in austral temperate rain forest bryophytes 5. New Zeal. J. Bot. 38, 415-423.

Piippo, S. (1990). Annotated catalogue of Chinese Hepaticae and Anthocerotae. J. Hattori Bot. Lab. 68, 1-192.

Qiu, Y.L. (2008). Phylogeny and evolution of charophytic algae and land plants. J. Syst. Evol. 46, 287-306.

Qiu, Y.L., Li, L.B., Wang, B., Chen, Z.D., Knoop, V., Groth-Malonek, M., Dombrovska, O., Lee, J., Kent, L., Rest, J., Estabrook, G.F., Hendry, T.A., Taylor, D.W., Testa, C.M., Ambros, M., Crandall-Stotler, B., Duff, R.J., Stech, M., Frey, W., Quandt, D. and Davis, C.C. (2006). The deepest divergences in land plants inferred from phylogenomic evidence. Proc. Natl. Acad. Sci. U.S.A. 103, 15511-15516.

Ramaiya, M., Johnston, M.G., Shaw, B., Heinrichs, J., Hentschel, J., von Konrat, M., Davison, P.G. and Shaw, A.J. (2010). Morphologically cryptic biological species within the liverwort, Frullania asagrayana. Amer. J. Bot. 97, 1707-1718.

Reiner-Drehwald, M.E. (1999). Catalogue of the genus Lejeunea Lib. (Hepaticae) of Latin America. Bryophyt. Bibl. 54, 1-101.

Reiner-Drehwald, M.E. (2007). Preliminary key to the genus Lejeunea in Brazil (draft version 30 April 2007). 
Reiner-Drehwald, M.E. and Drehwald, U. (2002). Sphaerolejeunea umbilicata (Lejeuneaceae): a critically endangered epiphyllous liverwort of the Andes. The Bryologist 105, 422-430.

Reiner-Drehwald, M.E. and Goda, A. (2000). Revision of the genus Crossotolejeunea (Lejeuneaceae, Hepaticae). J. Hattori Bot. Lab., 1-54.

Reiner-Drehwald, M.E. and Gradstein, S.R. (1995). Myriocoleopsis riparia (Lejeuneaceae), a new species from south-eastern Brazil and north-eastern Argentina. J. Bryol. 18, 479-484.

Reiner-Drehwald, M.E. and Ilkiu-Borges, A.L. (2007). Lejeunea huctumalcensis, a widely distributed Lejeuneaceae from the Neotropics, and its relation to Ceratolejeunea. The Bryologist 110, 465-474.

Reiner-Drehwald, M.E. and Schafer-Verwimp, A. (2008b). On Inflatolejeunea, Lejeunea species with eplicate perianths and Lejeunea talamancensis sp. nov. from Costa Rica (Lejeuneaceae). Nova Hedwigia 87, 387-420.

Renner, M.A.M. (2012). Further insight into lobule teeth homology in Lejeuneaceae subf. Lejeuneoideae from Cheilolejeunea oscilla, a new species from Australia. The Bryologist 115, 536-556.

Renner, M.A.M., Brown, E.A. and Wardle, G.M. (2011). The Lejeunea tumida species group is positively polyphyletic (Lejeuneaceae: Jungermanniopsida). Aust. Syst. Bot. 24, 10-18.

Renzaglia, K.S., Duff, R.J., Nickrent, D.L. and Garbary, D.J. (2000). Vegetative and reproductive innovations of early land plants: implications for a unified phylogeny. Phil. Trans. Biol. Sci. 355, 769-793.

Rubasinghe, S.C.K., Milne, R., Forrest, L.L. and Long, D.G. (2011). Realignment of the genera of Cleveaceae (Marchantiopsida, Marchantiidae). The Bryologist 114, 116-127. 
Sakakibara, K., Ando, S., Yip, H.K., Tamada, Y., Hiwatashi, Y., Murata, T., Deguchi, H., Hasebe, M. and Bowman, J.L. (2013). KNOX2 genes regulate the haploid-to-diploid morphological transition in land plants. Science 339, 1067-1070.

Sakakibara, K., Nishiyama, T., Deguchi, H. and Hasebe, M. (2008). Class 1 KNOX genes are not involved in shoot development in the moss Physcomitrella patens but do function in sporophyte development. Evol. Dev. 10, 555-566.

Samigullin, T.H., Valiejo-Roman, K.M., Troitsky, A.V., Bobrova, V.K., Filin, V.R., Martin, W. and Antonov, A.S. (1998). Sequences of rDNA internal transcribed spacers from the chloroplast DNA of 26 bryophytes: properties and phylogenetic utility. Febs Lett. 422, 47-51.

Sano, R., Juarez, C.M., Hass, B., Sakakibara, K., Ito, M., Banks, J.A. and Hasebe, M. (2005). KNOX homeobox genes potentially have similar function in both diploid unicellular and multicellular meristems, but not in haploid meristems. Evol. Dev. 7, 6978.

Schäfer-Verwimp, A. (2004). The genus Diplasiolejeunea (Lejeuneaceae, Marchantiopsida) in the tropical Andes, with description of two new species. Cryptog. Bryol. 25, 3-17.

Schäfer-Verwimp, A. (2006). A new species of Diplasiolejeunea (Lejeuneaceae, Jungermanniopsida) from Sumatra, and a key for the genus in Asia. Herzogia 19, 239244.

Schäfer-Verwimp, A. and Reiner-Drehwald, M.E. (2009). Some additions to the bryophyte flora of Guadeloupe, West Indies, and new synonyms in the genera Diplasiolejeunea and Lejeunea. Cryptog. Bryol. 30, 357-375.

Schaumann, F., Frey, W., de Menendez, G.H. and Pfeiffer, T. (2003). Geomolecular divergence in the Gondwanan dendroid Symphyogyna complex (Pallaviciniaceae, Hepaticophytina, Bryophyta) - Studies in austral temperate rain forest bryophytes 22. Flora 198, 404-412. 
Schiffner, V. (1893). Hepaticae. Nat. Pflanzenfam. 1, 97-141.

Schill, D.B., Long, D.G. and Forrest, L.L. (2010). A molecular phylogenetic study of Mannia (Marchantiophyta, Aytoniaceae) using chloroplast and nuclear markers. Bryologist 113, 164-179.

Schuster, R.M. (1957). North American Lejeuneaceae VI. Lejeunea: introduction and keys; subgenus Lejeunea I. J. Elisha Mitchell Sci. Soc. 73, 122-197.

Schuster, R.M. (1963). An annotated synopsis of the genera and subgenera of Lejeuneaceae. Nova Hedwigia 9, 1-203.

Schuster, R.M. (1980). The Hepaticae and Anthocerotae of North America Vol. IV, Columbia Univ. Press, New York.

Schuster, R.M. (1983). Phytogeography of the bryophyta. New manual of bryology 1, 626.

Schuster, R.M. (1984). Evolution, phylogeny and classification of the Hepaticae. New manual of bryology 2, 892-1070.

Schuster, R.M. (1994). Studies on Lejeuneaceae, I. Preliminary studies on new genera of Lejeuneaceae J. Hattori Bot. Lab. 75, 211-235.

Schuster, R.M. and Schäfer-Verwimp, A. (1995). On Pluvianthus (Lejeuneaceae: Lejeuneoideae). Nova Hedwigia 60, 59-72.

Self, S.L. (2002). The systematic status of Pelliax appalachiana R.M. Schust, Southern Illinois University Carbondale.

Shaw, A.J. (1998). Genetic analysis of a hybrid zone in Mielichhoferia (Musci) Leeds, UK, Maney Publishing and the British Bryological Society.

Shaw, A.J. (2001). Biogeographic patterns and cryptic speciation in bryophytes. J. Biogeogr. 28, 253-261. 
Shaw, A.J. and Goffinet, B. (2000). Molecular evidence of reticulate evolution in the peatmosses (Sphagnum), including S. ehyalinum sp. nov. The Bryologist 103, 357374.

Shaw, A.J., McDaniel, S.F., Werner, O. and Ros, R.M. (2002). New frontiers in bryology and lichenology - phylogeography and phylodemography. The Bryologist 105, 373383.

Shaw, A.J., Szovenyi, P. and Shaw, B. (2011). Bryophyte diversity and evolution: windows into the early evolution of land plants. Am. J. Bot. 98, 352-369.

Singer, S.D. and Ashton, N.W. (2007). Revelation of ancestral roles of KNOX genes by a functional analysis of Physcomitrella homologues. Plant Cell Rep. 26, 2039-2054.

Snall, T., Hagstrom, A., Rudolphi, J. and Rydin, H. (2004). Distribution pattern of the epiphyte Neckera pennata on three spatial scales - importance of past landscape structure, connectivity and local conditions. Ecography 27, 757-766.

Solari, S.S. (1983). Lejeuneaceae. catalogo de especies Andinopatagonicas. J. Hattori Bot. Lab. 54, 533-553.

Spruce, R. (1884). Hepaticae Amazonica et Andinae. Trans. Proc. Bot. Soc. Edinburgh $15,1-588$.

Stech, M. and Frey, W. (2001). CpDNA-relationship and classification of the liverworts (Hepaticophytina, Bryophyta). Nova Hedwigia 72, 45-58.

Stech, M. and Frey, W. (2004). Molecular circumscription and relationships of selected Gondwanan species of Haplomitrium (Calobryales, Haplomitriopsida, Hepaticophytina) - Studies in austral temperate rain forest bryophytes 24 . Nova Hedwigia 78, 57-70.

Stephani, F. (1898-1900). Species Hepaticarum I: 1-413. Georg \& Cie, Genève et Bâle, Lyon.

Stephani, F. (1901-1906). Species Hepaticarum II: 1-615. Georg \& Cie, Genève et Bâle, Lyon. 
Stephani, F. (1905-1908). Species Hepaticarum III: 1-693. Georg \& Cie, Genève et Bâle, Lyon.

Stephani, F. (1909-1912). Species Hepaticarum IV: 1-824. Georg \& Cie, Genève et Bâle, Lyon.

Stephani, F. (1912-1917). Species Hepaticarum V: 1-1044. Georg \& Cie, Genève et Bâle, Lyon.

Stephani, F. (1917-1925). Species Hepaticarum VI: 1-763. Jent, S.A., Genève.

Sukkharak, P., Gradstein, S.R. and Stech, M. (2011). Phylogeny, taxon circumscriptions, and character evolution in the core Ptychanthoideae (Lejeuneaceae, Marchantiophyta). Taxon 60, 1607-1622.

Thiers, B.M. (1983). Branching in Lejeuneaceae II. Nipponolejeuneoideae, Tuyamaelloideae and Myriocoleoideae. Lindbergia 10, 4-18.

Thiers, B.M. (1997). Lejeunea bischlerae, a new species of Lejeunea subgenus Microlejeunea from Australia. Cryptog. Bryol. 18, 223-226.

Timme, R.E., Bachvaroff, T.R. and Delwiche, C.F. (2012). Broad phylogenomic sampling and the sister lineage of land plants. Plos One 7, e29696.

Tixier, P. (1985). Contribution à la connaicance des Cololejeunoideae. Bryophyt. Biblioth 27, 1-439.

Turmel, M., Ehara, M., Otis, C. and Lemieux, C. (2002). Phylogenetic relationships among streptophytes as inferred from chloroplast small and large subunit rRNA gene sequences. J. Phycol. 38, 364-375.

Turmel, M., Otis, C. and Lemieux, C. (2006). The chloroplast genome sequence of Chara vulgaris sheds new light into the closest green algal relatives of land plants. Mol. Biol. Evol. 23, 1324-1338. 
Turmel, M., Pombert, J.F., Charlebois, P., Otis, C. and Lemieux, C. (2007). The green algal ancestry of land plants as revealed by the chloroplast genome. Int. J. Plant Sci. 168, 679-689.

Van der Velde, M. and Bijlsma, R. (2003). Phylogeography of five Polytrichum species within Europe. Biol. J. Linn. Soc. 78, 203-213.

Van Steenis, C.G.G. (1981). Rheophytes of the world.

van Zanten, B.O. (1978). Experimental studies on trans-oceanic long-range dispersal of moss spores in the Southern Hemisphere. J. Hattori Bot. Lab. 44, 455-482.

Van Zanten, B.O. and Pócs, T. (1981). Distribution and dispersal of bryophytes. Advances Bryol. 1, 479-562.

Vanderpoorten, A., Devos, N., Goffinet, B., Hardy, O.J. and Shaw, A.J. (2008). The barriers to oceanic island radiation in bryophytes: insights from the phylogeography of the moss Grimmia montana. J. Biogeogr. 35, 654-663.

Vanderpoorten, A., Gradstein, S.R., Carine, M.A. and Devos, N. (2010). The ghosts of Gondwana and Laurasia in modern liverwort distributions. Biol. Rev. 85, 471-487.

Vilnet, A.A., Konstantinova, N.A. and Troitsky, A.V. (2008). Phylogeny and systematics of the genus Lophozia s. str. (Dumort.) Dumort. (Hepaticae) and related taxa from nuclear ITS1-2 and chloroplast trnL-F sequences. Mol. Phylogenet. Evol. 47, 403-418.

Vilnet, A.A., Konstantinova, N.A. and Troitsky, A.V. (2009). Genosystematics and new insight into the phylogeny and taxonomy of liverworts. Mol. Biol. 43, 783-793.

von Konrat, M., de Lange, P., Greif, M., Strozier, L., Hentschel, J. and Heinrichs, J. (2012). Frullania knightbridgei, a new liverwort (Frullaniaceae, Marchantiophyta) species from the deep south of Aotearoa-New Zealand based on an integrated evidence-based approach. PhytoKeys 8, 13-36. 
Von Konrat, M., Soderstrom, L., Renner, M.A.M., Hagborg, A., Briscoe, L. and Engel, J.J. (2010). Early Land Plants Today (ELPT): how many liverwort species are there? Phytotaxa 9, 22-40.

Wahrmund, U., Groth-Malonek, M. and Knoop, V. (2008). Tracing plant mitochondrial DNA evolution: rearrangements of the ancient mitochondrial gene cluster trnA-trnTnad7 in liverwort phylogeny. J. Mol. Evol. 66, 621-629.

Weeks, A., Daly, D.C. and Simpson, B.B. (2005). The phylogenetic history and biogeography of the frankincense and myrrh family (Burseraceae) based on nuclear and chloroplast sequence data. Mol. Phylogenet. Evol. 35, 85-101.

Wellman, C.H., Osterloff, P.L. and Mohiuddin, U. (2003). Fragments of the earliest land plants. Nature 425, 282-285.

Wheeler, J.A. (2000). Molecular phylogenetic reconstructions of the marchantioid liverwort radiation. The Bryologist 103, 314-333.

Wiggington, M.J. (2004). E.W Jones's liverwort and hornwort flora of West Africa, National Botanic Garden of Belgium.

Wigginton, M.J. and Grolle, R. (1996). Catalogue of the Hepaticae and Anthocerotae of Sub-Saharan Africa. Bryophyt. Biblioth. 50, 1-267.

Wilson, R., Gradstein, S.R., Heinrichs, J., Groth, H., Ilkiu-Borges, A.L. and Hartmann, F.A. (2004). Phylogeny of Lejeuneaceae: a cladistic analysis of chloroplast gene rbcL sequences and morphology with preliminary comments on the mitochondrial nad4-2 spacer region. Monogr. Syst. Bot. Mo. Bot. Gard. 98, 189-202.

Wilson, R., Gradstein, S.R., Schneider, H. and Heinrichs, J. (2007a). Unravelling the phylogeny of Lejeuneaceae (Jungermanniopsida): evidence for four main lineages. Mol. Phylogenet. Evol. 43, 270-282.

Wilson, R., Heinrichs, J., Hentschel, J., Gradstein, S.R. and Schneider, H. (2007b). Steady diversification of derived liverworts under Tertiary climatic fluctuations. Biology Letters 3, 566-569. 
Wodniok, S., Brinkmann, H., Glockner, G., Heidel, A.J., Philippe, H., Melkonian, M. and Becker, B. (2011). Origin of land plants: do conjugating green algae hold the key? BMC Evol. Biol. 11.

Wolf, P.G., Schneider, H. and Ranker, T.A. (2001). Geographic distributions of homosporous ferns: does dispersal obscure evidence of vicariance? J. Biogeogr. 28, 263-270.

Ye, W., Wei, Y.M., Schäfer-Verwimp, A. and Zhu, R.L. (2013). Phylogenetic position of Oryzolejeunea (Lejeuneaceae, Marchantiophyta): evidence from molecular markers and morphology. J. Syst. Evol. 51, 468-475.

Zartman, C.E. (2003). Habitat fragmentation impacts on epiphyllous bryophyte communities in central Amazonia. Ecology 84, 948-954.

Zartman, C.E., McDaniel, S.F. and Shaw, A.J. (2006). Experimental habitat fragmentation increases linkage disequilibrium but does not affect genetic diversity or population structure in the Amazonian liverwort Radula flaccida. Mol. Ecol. 15, 23052315.

Zartman, C.E. and Nascimento, H.E.M. (2006). Are habitat-tracking metacommunities dispersal limited? Inferences from abundance-occupancy patterns of epiphylls in Amazonian forest fragments. Biol. Conserv. 127, 46-54.

Zhu, R.L. and So, M.L. (2001). Epiphyllous liverworts of China. Nova Hedwigia 121, 1418. 


\section{Appendix 1}

\section{Tramps, narrow endemics and morphologically cryptic species in the epiphyllous liverwort Diplasiolejeunea}

Shanshan Dong, Alfons Schäfer-Verwimp, Philipp Meinecke, Kathrin Feldberg, Andrea

Bombosch, Tamás Pócs, Alexander R. Schmidt, Joachim Reitner, Harald Schneider, Jochen Heinrichs

Published in MolecularPhylogen etics and Evolution 2012, 65, 582-594. 


\section{Abstract}

Diplasiolejeunea is a pantropical, epiphytic genus of leafy liverworts that occurs from the lowlands to more than $4000 \mathrm{~m}$. Phylogenetic analyses of a molecular dataset consisting of three markers (nuclear ribosomal ITS region, plastidic trnL-F region and rbcL gene) and 122 accessions (plus two outgroups, Colura and Cololejeunea) indicate that the evolutionary diversity of Diplasiolejeunea is underestimated by current morphology-based classification. Four morphologically semi-cryptic species have been recovered. The molecular phylogenies support a deep split into a Neotropical and a Paleotropical clade, the latter structured into Australasian, Asian and Afromadacascan lineages. Presented results confirm the ranges of two pantropical species ( $D$. cavifolia, $D$. rudolphiana), provide evidence for dispersal from the Neotropics into the Paleotropics, indicate speciation along altitudinal gradients and demonstrate extensive morphological homoplasy. We propose a revised supraspecific classification of Diplasiolejeunea into a predominantly Paleotropical subgenus Physolejeunea and predominantly Neotropical subgenera Austrolejeuneopsis and Diplasiolejeunea, the former containing mainly epiphytic species, the latter mainly epiphylls. Several clades are supported by combinations of morphological character states, and could be assigned to sections at some later point. This is the first comprehensive phylogeny of a largely epiphyllous genus of liverworts.

Keywords: classification, dispersal, Lejeuneaceae, phylogenetic biogeography, Porellales,

\section{Introduction}

Molecular phylogenetic studies have greatly improved our understanding of relationships within liverworts. These studies led to numerous adjustments of family and genus concepts (Crandall-Stotler et al., 2009) and allowed for new insights into their biogeography (Shaw, 2001). Among the most remarkable findings was the evolutionarily dynamic nature of liverworts (Heinrichs et al., 2009a; Vanderpoorten et al., 2010a), rejecting the hypothesis of bryophytes being "unmoving, unchanging sphinxes of the past" (Crum, 1972). However, this dynamic nature of colonization, extinction and local 
differentiation is often poorly recognizable using morphological evidence alone and thus breakthrough studies required the application of molecular methods ranging from isozyme studies to DNA based studies, the latter using haplotype variation at population level and phylogenetic approaches at deeper taxonomic levels (Odrzykoski and Szweykowski, 1991; Feldberg et al., 2007; Devos and Vanderpoorten, 2009; Forrest et al., 2011; Heinrichs et al., 2011; Laenen et al., 2011). Related studies demonstrated a complex genetic structure of morphologically circumscribed liverwort species and provided evidence for morphologically cryptic or semicryptic speciation (Wachowiak et al., 2007; Fuselier et al., 2009; Heinrichs et al., 2010; Ramaiya et al., 2010; Heinrichs et al., 2011). It is now proven that only species-level phylogenies with extensive population sampling will allow for an approximation of the actual liverwort diversity, and to better understand speciation processes and distribution range formation (Kreier et al., 2010).

Lejeuneaceae, with an estimated number of about 1000 species (Wilson et al., 2007a), represent the most species rich epiphytic lineage of leafy liverworts (Heinrichs et al., 2005a). This family is common throughout the humid tropics, especially in the lowlands were up to $70 \%$ of the present liverworts belong to Lejeuneaceae (Cornelissen and Ter Steege, 1989; Zartman, 2003). In epiphyllous communities Lejeuneaceae are even more dominant, totalling to more than $90 \%$ of the present bryophyte species (Pócs, 1996; Sonnleitner et al., 2009; Benavides \& Sastre-De Jesús, 2011). Epiphyllous Lejeuneaceae are characterized by a rather small or even minute size, frequent vegetative reproduction by multicellular, disciform gemmae, and are closely attached to the substratum (Gradstein et al., 1997). Due to their diminutive size and reduced morphology, it is far from surprising that they belong to the taxonomically most difficult groups of Lejeuneaceae (Gradstein et al., 2006).

Diplasiolejeunea is a pantropical, partly epiphyllous Lejeuneaceae genus growing on living leaves, fine twigs, and smooth-barked trunks, usually in well-illuminated sites from sea level to $4150 \mathrm{~m}$ (Gradstein et al., 2001; Schäfer-Verwimp, 2004). This genus is easily recognized by the presence of one underleaf per leaf in combination with rather large but not sac-like leaf lobules (Zhu \& So, 2001). Diplasiolejeunea species taxonomy has been the subject of several morphological studies, often with controversial results (Grolle, 
1966; Tixier, 1985; Schäfer-Verwimp, 2004, 2006; Pócs, 2006; Pócs and SchäferVerwimp, 2006; Schäfer-Verwimp and Reiner-Drehwald, 2009). The uncertainty regarding species circumscription has led to divergent estimates of global diversity, ranging from 35 (Schuster, 1980) to 70 Diplasiolejeunea species (Schäfer-Verwimp, 2006). Most of these species seem to have rather narrow distribution ranges, in contrast to the pantropical ranges of $D$. cavifolia Steph., D. cobrensis Steph. and D. rudolphiana Steph. (Grolle, 1995; Zhu \& So, 2001).

Up to now, less than $20 \%$ of the Lejeuneaceae species have been included in molecular phylogenetic studies (Ahonen et al., 2002; Hartmann et al., 2006; Wilson et al., 2007a; Heinrichs et al., 2009b; Gradstein et al., 2011; Renner et al., 2011; Sukkharak et al., 2011); hence this family is in need of further investigations. Here we present the first global phylogeny of a partly epiphyllous genus of Lejeuneaceae, Diplasiolejeunea, based on 122 accessions that cover the whole range of the genus, and sequences from the nuclear ribosomal internal transcribed spacer region (nrITS), along with the plastid DNA rbcL gene, and the trnL-F region. We test current species and range concepts by including multiple accessions and examine whether the recovered phylogenetic relationships correspond to/or conflict to morphologically circumscribed taxa. Our data support intercontinental ranges of a few Diplasiolejeuna species, presence of several so far unrecognised species, morphologically cryptic speciation, diversification along altitudinal gradients, and geographically separated main clades.

\section{Material and methods}

\subsection{Taxon sampling and outgroup selection}

Taxa studied, including GenBank accession numbers and voucher details, are listed in Table 1. All voucher specimens were carefully examined and original identifications were corrected when necessary. To identify DNA vouchers we used monographic treatments (e.g., Tixier, 1985; Reyes, 1982; Schäfer-Verwimp et al., 2004, 2006), original descriptions (e.g., Schäfer-Verwimp et al., 2005; Pócs and Schäfer-Verwimp, 2006) and type material preserved in the herbaria EGR, G, GOET, JE, and PC (abbreviations according to Holmgren et al., 1990). 
Besides availability of material, ingroup taxa were selected to represent the morphological variation and geographical distribution of Diplasiolejeunea. Multiple accessions of several species were used to explore intraspecific genetic variation. Based on the analyses of Gradstein et al. (2006) and Wilson et al. (2007a), Cololejeunea vitalana and Colura acroloba were designated as outgroup taxa for phylogenetic reconstruction.

\subsection{DNA extraction, PCR amplification and sequencing}

Plant tissue was isolated from herbarium collections. Total genomic DNA was purified using Invisorb Spin Plant Mini Kit (Invitek, Berlin, Germany) prior to amplification. Protocols for PCR were carried out as described in previous publications: $r b c L$ gene and trnL-F region from Gradstein et al. (2006), and nrITS1-5.8S-ITS-2 region from Hartmann et al. (2006). Bidirectional sequences were generated using a MegaBACE 1000 automated sequencing machine using DYEnamic ET Primer DNA Sequencing Reagent (Amersham Biosciences, Little Chalfont, UK). Sequencing primers were those used for PCR. Voucher specimens for all sequences were deposited in EGR, GOET or JE. Three hundred and fourty three sequences were newly generated for this study; 9 sequences were downloaded from Genbank (http://www.ncbi.nlm.nih.gov/genbank/).

\subsection{Phylogenetic analyses}

All sequences were aligned manually in Bioedit version 7.0.5.2 (Hall, 1999). Ambiguous positions were excluded from all alignments and lacking data were coded as missing. Some analyses were carried out using a comprehensive alignment including all studied accessions, whereas other analyses used a reduced alignment with one accession per taxon as required for plotting of several morphological characters and ecological preferences (see Table 2). The reduced alignment comprises the accessions with the most complete sequences. The $r b c L$ sequence of the $D$. plicatiloba specimen Schäfer-Verwimp 14246 was combined with the trnLF and ITS sequences of specimen Pócs 0057/R to get a complete sequence set for the reduced alignment.

Maximum parsimony (MP) analyses were carried out with PAUP* version $4.0 \mathrm{~b} 10$ 
(Swofford, 2000). MP heuristic searches of the comprehensive and the reduced datasets were conducted with the following options implemented: heuristic search mode, 1000 random-addition-sequence replicates, tree bisection-reconnection (TBR) branch swapping, MULTrees option on, and collapse zero-length branches off. All characters were treated as equally weighted and unordered. Non-parametric bootstrapping values (Felsenstein, 1985) were generated as heuristic searches with 1,000 replicates, each with ten random-addition replicates. The number of rearrangements was restricted to ten millions per replicate. Bootstrap percentage values (BPVs) $\geq 70$ were regarded as good support (Hillis and Bull, 1983). Where more than one most parsimonious tree was found, trees were summarized in a strict consensus tree.

The three genomic regions and the combined chloroplast DNA dataset vs nrITS dataset were first analysed separately to check for incongruence. The strict consensus trees of the non-parametric bootstrap analyses were compared by eye to identify conflicting nodes supported by at least 70\% (Mason-Gamer and Kellog, 1996). The trees gave no evidence of incongruence. Hence the datasets were combined. The influence of $D$. alata on the robustness of the reconstructed phylogeny was tested by excluding this species from the analyses. jModeltest 0.1 (Posada, 2008) was used to select a model of evolution for the maximum likelihood $(\mathrm{ML})$ analyses of the large combined dataset. A General Time Reversible (GTR) model (Tavaré, 1986) was chosen with proportion of invariable characters $(I)$ and among-site rate heterogeneity modelled as discrete gamma distribution with four rate categories, and its estimated parameters ( $Г)$ (Goldman, 1993). $M L$ trees were generated using the programs PAUP* and GARLI version 0.96 beta (Zwickl, 2006). The PAUP*-Analysis was performed as heuristic search, MULTrees option on, collapse zero length branches off, and TBR branch swapping. All GARLI analyses were performed with the default settings and several times repeated. The default setting of GARLI was also employed to calculate bootstrap values for $\mathrm{ML}$ analyses based on 200 bootstrap replicates.

Bayesian inference was implemented in MrBayes 3.1.2 (Huelsenbeck and Ronquist, 2001) on the large combined dataset using a GTR substitution model. A Bayesian search was carried out with four simultaneous Markov chains, ten million generations 
and sampling every 100th generation. Tracer version 1.3 (Rambaut and Drummond, 2003) was used to examine the parameters and determine the number of trees needed to reach stationarity (burn-in). Bayesian posterior probability (BPP) confidence values were generated from trees saved after this initial burn-in. Values were regarded as significant when BPP $\geq 0.95$ (Larget and Simon, 1999).

\subsection{Reconstruction of ancestral areas of distribution, distribution of morphological character states and growth preferences}

Ancestral areas of distribution were reconstructed using MP criteria as implemented in Mesquite ver. 2.72 (Maddison and Maddion, 2004) based on the ML topology of the combined dataset. Data on distribution ranges of the investigated taxa were obtained from the literature, in addition to own observations. Given the wide distribution ranges of some species, the putative distribution range of endemism was coded as covering four possible areas: Neotropics, Afromadagascar, Asia, Australasia. The ranges of the outgroup species were coded as "unknown" because the closest relatives of Diplasiolejeunea have not yet been determined (see Wilson et al. 2007a). We plotted several morphological characters (see table 2) on the MP tree of the reduced dataset that are relevant for the systematics of the genus (Schuster, 1970; Tixier, 1985; SchäferVerwimp, 2004). We did not map generative structures because of their high infraspecific variation in the current Diplasiolejeunea classification. Growth preferences of the investigated characters were mapped based on own observations during fieldwork in all parts of the tropics, and data from the literature. We also mapped the altitude of the DNA vouchers on the ML topology.

\section{Results}

\subsection{Small combined dataset}

Of a total of 2148 character sites, 467 were parsimony informative, 257 autapomorphic and 1424 constant. The MP analysis resulted in four equally parsimonious trees with a length of 2116 steps, a consistency index $(\mathrm{Cl})$ of 0.48 and a retention index $(\mathrm{Rl})$ of 0.61 . The strict consensus tree is depicted in Fig. 1.

Diplasiolejeunea is split into a well supported $(\mathrm{BPV}=78)$ mainly Neotropical clade II, 
and an unsupported $(B P V<50)$ Paleotropical clade I with the Australasian D. plicatiloba (clade I-a) placed sister to a clade that is divided into an Asian (clade 1-b) and an Afromadagascan lineage (clade I-c). Clade I includes the type of $D$. subgen. Physolejeunea, D. plicatiloba. Clade II splits into an unsupported clade II-a with the type of $D$. subgen. Austrolejeuneopsis, D. alata, and a robust $(B P V=87)$ clade II-b with the generitype $D$. pellucida. Diplasiolejeunea alata forms a long branch in all MP trees (not shown). Exclusion of $D$. alata from the dataset does not lead to changes in the topology but to a BPV of 75 for clade II-a. All investigated morphological characters proved to be homoplasious but several derived clades share certain character state combinations. Clade II-a includes mostly epiphytes wheras the majority of species belonging to clade II-b predominanly occurs as epiphylls.

\subsection{Large combined dataset}

The PAUP* ML analysis of the large dataset led to three nearly identical topologies with $-\ln =18325.54055$, of which one is depicted in Fig. 2. This topology was also found with GARLI and Mrbayes. The MP topology is confirmed with the extended dataset albeit with high BPV and BPP values for both clade I (90/0.99) and clade II (91/1.00). The sister relationship of the Asian and the Afromadagascan clade is well supported with a BPV of 75 but gets no significant support in the Bayesian analysis. Multiple accessions of morphologically circumscribed species form monophyletic lineages with the exception of $D$. unidentata nested in $D$. rudolphiana and $D$. caribea nested in $D$. pellucida. Diplasiolejeunea pauckertii and $D$. pluridentata are polyphyletic. Five accessions represent undescribed species.

Pantropical ranges are confirmed for $D$. cavifolia and $D$. rudolphiana although the ancestral area reconstruction indicates a Neotropical origin of these species (Fig. 3). Accessions of $D$. subgen. Austrolejeuneopsis were usually collected in high montane regions, in addition to a few accessions from the lowlands or low montane regions ( $D$. rudolphiana, $D$. unidentata). Representatives of $D$. subgen. Diplasiolejeunea were mostly collected in low montane regions or lowlands. 


\section{Discussion}

\subsection{Supraspecific classification}

Schuster (1970) classified Diplasiolejeunea in three subgenera, Austrolejeuneopsis, Physolejeunea and Diplasiolejeunea s.str. based on the absence (Austrolejeuneopsis, Physolejeunea) or presence of ocelli (Diplasiolejeunea s.str.). He set up subgen. Physolejeunea to include a single Australasian species with very large leaf lobules, $D$. plicatiloba (as D. lyratifolia), and proposed subgen. Austrolejeuneopsis - typified with the Neotropical $D$. alata - for a few species with moderately sized, strongly inflated lobules.

This classification is not supported by the molecular phylogenies (Figs. 1 and 2) since the few species without ocelli are diffusely distributed in the molecular topologies (Fig. 1, character 3), and the type species of subgen. Austrolejeuneopsis and Physolejeunea nested in subgen. Diplasiolejeunea sensu Schuster (1970) and Tixier (1985). Our attempt to refine the present classification is hampered by the extensive morphological homoplasy observed in the genus (Fig. 1). However, the recovered phylogenetic hypothesis mirrors geographical differentiation with one mainly Neotropical and one Paleotropical main clade, the latter subdivided in Australasian, Asian and Afromadagascan lineages (Fig. 2). We propose to assign the name $D$. subgen. Physolejeunea to the Paleotropical main clade I, and to use the names $D$. subgen. Austrolejeuneopsis and D. subgen. Diplasiolejeunea for the predominantly Neotropical clades Ila and Ilb (Fig. 1). These assignments reflect the relationships of the type species of each clade, $D$. plicatiloba nested in clade I, $D$. alata nested in clade Ila, and $D$. pellucida nested in clade Ilb. Subgen. Physolejeunea achieves good bootstrap support only in the ML analysis; subgen. Austrolejeuneopsis is unsupported in both the MP and $\mathrm{ML}$ analyses. However, the lack of support for subgen. Austrolejeuneopsis is caused by the "long branch" taxon D. alata; exclusion of this species leads to a MP bootstrap percentage value of 75 for this clade. The long-branch of Diplasiolejeunea alata is not caused by a large inversion or related structural evolution event but appears to be the result of higher mutation rates than average rate of Diplasiolejeunea. The long branch has been found in both, the nuclear and the chloroplast datasets (data not shown). 
Diplasiolejeunea s.str. includes predominantly epiphyllous species whereas epiphytic occurrences are more typical for subgen. Austrolejeuneopsis. The different subclades of clades I, Ila, and Ilb differ by certain character state combinations or tendencies, e.g., inflexed leaf margins in combination with strongly inflated lobules and ovate, acute underleaves in clade II-a1 (Fig. 1), and can be assigned to sections Physolejeunea (la), Cornutae (Ib), Austrolejeuneopsis (Ila2) and Diplasiolejeunea (llb2). New sections for subclades Ib, Ila3, Illb1 will be established elsewhere.

\subsection{Species classification}

In this study, we explore the support of species that are defined using a morphological-typological approach. We sample multiple accessions of morphologically circumscribed species and explore their consistence with the molecular data using monophyly as the core criterion. The majority of currently accepted species concepts, e.g. the different forms of phylogenetic species concepts and the unified species concept (de Queiroz, 2007), consider reciprocal monophyly as the explicit criterion or a property of species. Incongruence of morphological taxa with DNA sequence based phylogenetic results is considered as evidence for limitations of species concepts relying exclusively on the diagnostics of morphological features. We consider here only three criteria, diagnostic morphology, biogeographic consistency, and reciprocal monophyly, in the absence of studies on the reproductive biology. However, we need to stress out the recovered congruence between phylogenetic hypothesis obtained from DNA sequences of either the chloroplast or the nuclear markers. These results may be valued as indicators of reproductive isolation.

Based on the phylogeny shown in Fig. 2 we propose several refinements of the current Diplasiolejeunea classification including recognition of five new species that will be formally described in a separate paper. Only one of the five new species (Fig. 1, spec. nov. V) was tentatively identified as an undescribed entity prior to the molecular study based on its morphological characters. Four of the five new species were placed in currently accepted species prior to our molecular investigation, but in some cases weak morphological disparities were already recognized. New species I was originally 
identified as $D$. pauckertii but stands out among specimens identified as this species by very densely arranged, squarrose leaves. The new species II and III were identified as $D$. cavifolia but were collected at higher altitudes than D. cavifolia s.str. (Fig. 3). Morphologically they differ slightly in underleaf shape, general lack of T-like lobule teeth, gender distribution, and lack of gemmae. One new species (spec. nov. IV) resembles $D$. caribea but stands out by leaf lobes with a broad marginal border consisting of small, subquadrate to (short-)rectangular cells. The study of additional material will likely result in a better understanding of the morphological disparity among these species and allow to identify characters for specimen identification. However, morphology alone was not sufficient to recognize these phenotypes as independent biological entities, accentuating the importance of integrative, molecular-morphological studies to recognize the actual liverwort diversity ( Dayrat, 2005, Will et al., 2005 and Heinrichs et al., 2009b).

Our data tend to support narrow species concepts in Diplasiolejejeunea but the example $D$. inermis contradicts this finding (Fig. 2). Diplasiolejeunea inermis was separated from $D$. pellucida by a free tooth on the margin of the lobule (incurved in $D$. pellucida; Tixier, 1985) and can usually be separated without much doubt. We chose typical forms of both taxa including two specimens from the same locality in Venezuela (Venezuela 1: $D$. inermis, 2: $D$. pellucida). These accessions produced identical sequences and form a robust monophyletic lineage within $D$. pellucida (Fig. 2). We furthermore observed morphological intermediates when checking larger specimen sets. Based on our phylogeny and the observed intermediate forms we regard $D$. inermis as a synonym of $D$. pellucida, and the direction of the outer lobule tooth subject to infraspecific variation. The situation is complicated by the presence of $D$. caribea in the $D$. pellucida clade. This taxon differs from $D$. pellucida by its T-shaped first (median) and a free second (apical) lobule tooth and is possibly a recent derivative of a local $D$. pellucida population. Diplasiolejeunea malleiformis closely resembles $D$. pellucida and is often treated as a variety of the latter (Schäfer-Verwimp and Reiner-Drehwald, 2009). However, West Indian accessions of $D$. malleiformis form an independent lineage (Figs. $1,2)$. Incongruence of morphological and molecular variation is also seen in the $D$. rudolphiana / D. unidentata clade. Diplasiolejeunea rudolphiana and D. unidentata differ by the length and orientation of the lobule teeth, and sex distribution. However, both 
accessions of $D$. unidentata from Guadeloupe are nested in $D$. rudolphiana and placed sister to a $D$. rudolphiana accession from the same region. Inclusion of $D$. unidentata samples from other parts of the Neotropics is necessary to ellucidate the status of both taxa.

\subsection{Cryptic speciation}

There is increasing evidence for molecular variation without concordant morphological differentiation in liverworts. Morphologically cryptic biological entities have been observed in the genera Conocephalum (Odrzykoski and Szweykowski, 1991), Frullania (Ramaiya et. al., 2010), Leptoscyphus (Vanderpoorten et al., 2010b), Marchesinia (Heinrichs et al., 2009b), Metzgeria (Fuselier et al., 2009), Pellia (Odrzykoski et al., 1996), Ptilidium (Kreier et al., 2010) and others, and are also present in Diplasiolejeunea.

Diplasiolejeunea pauckertii is a narrowly circumscribed, montane species characterized by inrolled leaf lobules with obscurely toothed free margins, ocelli and gemmae. However, a few $D$. pauckertii accessions are placed outside the main lineage of this species (Fig. 2). The accessions Ecuador (I) and (II) come from lower altitudes than other D. pauckertii accessions of this species (Fig. 3) and could thus be indicative of morphologically cryptic speciation along altitudinal gradients. Another $D$. pauckertii morphotype forms a robust monophyletic lineage with $D$. involuta ssp. andicola.

Diplasiolejeunea pluridentata occurs in similar habitats as $D$. pauckertii. Two accessions of this species form a paraphyletic grade within the $D$. pauckertii-involutaerostrata clade; another accession is placed sister to a clade with $D$. pauckertii and $D$. involuta ssp. andicola. It is still unclear if the grade holds when more accessions are included, and complete sequence stretches become available.

The pantropical species $D$. cavifolia is regarded to be a somewhat variable species (Schäfer-Verwimp and Reiner-Drehwald, 2009) including forms with strongly T-shaped 
lobule teeth (earlier recognized as $D$. matoubae and $D$. zacatepecensis) as well as forms without such teeth. This species forms a robust lineage with two main clades (Fig. 2); however, the different morphotypes are present in both. The two clades occur sympatrically in the West Indies, and can thus neither be separated using geographical nor morphological evidence. We consider $D$. cavifolia to be another example of morphologically cryptic speciation.

\subsection{Biogeography}

\subsubsection{Geographical pattern and evolution along altitudinal gradients.}

Both the MP and ML analyses (Fig. 1, Fig. 2 and Fig. 3) reveal a clear geographical pattern with a Paleotropical and a Neotropical main lineage. This clear pattern is surprising with regard to the high dispersal ability of spore plants (Wolf et al., 2001, van Zanten, 1978 and Vanderpoorten et al., 2010a), and to our knowlegde has not yet been documented for any other liverwort genus. The observed pattern could be indicative of Gondwanan vicariance, however, divergence time estimates suggest an origin of Diplasiolejeunea in the Oligocene (Wilson et al., 2007b), posterior to the Mesozoic breakup of the Southern landmass (McLoughlin, 2001). The main clades of Diplasiolejeunea seem to be the result of a few dispersal events in the early history of the genus, and subsequent local diversification. Mapping the altitudinal distribution and growth preferences of the investigated species on the molecular trees ( Fig. 1 and Fig. 3) reveals ecological and geographical tendencies for the Neotropical main clades Ila (subgen. Austrolejeuneopsis) and llb (subgen. Diplasiolejeunea). Subgenus Diplasiolejeunea includes species which grow predominantly on living leaves of angiosperms and ferns rather than on trunks and twigs. This preference for an epiphyllous growth is correlated with an occurrence in the lowlands and lower montane regions; however, a few exceptions prove the rule (D. pocsii, D. spec. nov. II and III). In contrast, subgen. Austrolejeuneopsis includes mostly montane or Andean species with a preference for epiphytic occurrences, in addition to a few epiphytes from lower altitudes. This pattern may sustain the hypothesis of a strong influence of the rise of the Northern and Central Andes on the assembly of this liverwort diversity by triggering the diversification of the Neotropical D. subg. Austrolejeuneopsis clade, perhaps by 
providing new habitats. Entrance of lowland and mid-elevation epiphytes into Andean cloud forests and subsequent speciation could explain the observed pattern, and has also been proposed for other neotropical plant groups including the fern Serpocaulon (Kreier et al., 2008) and Bromeliaceae (Givnish et al., 2004). In short, the recovered evidence indicates that the same processes influence the diversification of derived liverworts and angiosperms in the Neotropics (Pennington et al., 2010 and Antonelli and Sanmartin, 2011). Similar speculations cannot yet be made for the Paleotropical main clade since the regional sampling is still very limited, especially for continental Africa. Our attempts to extract DNA from numerous accessions from this region were unsuccessful with the exception of $D$. villaumei, of which three Kenyan and one Madagascan accession were studied (Fig. 2). The related sequences are very similar, and provide no evidence for a separation of East African Island and Continental African lineages as seen in Plagiochila sect. Vagae(Heinrichs et al., 2005b). The East African Islands have been regarded as a centre of diversification of Diplasiolejeunea (Tixier, 1985), and it would be worthwhile to carve out the relationships of the island and the mainland populations.

\subsubsection{Intercontinental species ranges, dispersal and migration routes}

Our study confirms a pantropical range of $D$. cavifolia. The considerable sequence similarities of the accessions forming the pantropical subclade (Fig. 2) indicate recent emergence and fast range expansions or occasional intercontinental gene exchange (Fig. 3). Pantropical ranges of liverworts are rather uncommon, and have otherwise been supported by molecular data only for Frullania arecae and F. ericoides (Hentschel et al., 2009).

According to morphological evidence (Zhu and So, 2001), D. rudolphiana is another pantropical species. We could include only accessions from the Neotropics and Madagascar in our sampling. These accessions form a robust monophyletic lineage together with accessions of $D$. unidentata (Fig. 2). The extensive sequence similarities of our $D$. rudolphiana accession from Guadeloupe and those from Madagascar may be more consistent with the hypothesis of recent long distance dispersal rather than the 
hypothesis of fragmentation of a broader range triggered by the climate cooling during the Neogene (Zachos et al., 2001). Diplasiolejeunea cavifolia and D. rudolphiana are nested in the Neotropical Diplasiolejeunea clade (Fig. 3), providing evidence for a Neotropical origin of these species and dispersal into the Paleotropics. The same direction of propagation has recently been proposed for several other liverwort species based on molecular phylogenies, e.g., for the tropical American-African Herbertus juniperoideus (Feldberg et al., 2007), Plagiochila boryana and $P$. corrugata (Heinrichs et al., 2005b). Diplasiolejeunea cobrensis is the third pantropical species within this genus, however, we were only able to sequence accessions from Madagascar and Mayotte; an accession from Brazil (Schäfer-Verwimp 8730b) did not yield PCR products. Although it would be desirable to test the range of this species with molecular data, we can tentatively reconstruct an Afromadagascan origin based on its presence in the Afromadagascan Diplasiolejeunea clade.

Diplasiolejeunea includes narrow endemics such as the Indonesian $D$. ingekarolae and widespread "tramp" species occurring on one to several continents. A similar situation is present in many spore plant lineages, and has been demonstrated, e.g., for the moss genus Daltonia with the pantropical species $D$. marginata and $D$. splachnoides (Yu et al., 2010), and the fern Nephrolepis with the pantropical species $N$. biserrata (Hennequin et al., 2010).

Germination experiments provided evidence for a higher survival rate of spores of widespread liverworts under conditions required to be successfully dispersed in the trade wind zones (van Zanten and Gradstein, 1988), even though the physiological characteristics of such spores are still largely unknown (Löbel and Rydin, 2010). Germination experiments have not yet been conducted in Diplasiolejeunea, hence we cannot explain the different ranges by characters of the spores. Many liverworts are capable of vegetative reproduction through propagules or unspecific gametophyte fragments. Vegetative reproduction by propagules has generally been accepted as an important dispersal mode for epiphytic bryophytes (van Zanten and Pócs, 1981), at least over short distances (Löbel and Rydin, 2010), and has been documented for the majority of Diplasiolejeunea species (Fig. 1, character 8). It is thinkable that these dispersal 
entities also contribute to the formation of disjunct ranges (Pohjamo et al., 2006). The pantropical species $D$. cavifolia and $D$. rudolphiana seem to have a broader ecological amplitude than other species of this genus, and occur not only in moist forests but also in more mesic woodlands, plantations and orchards (Gradstein et al., 2001). This broad amplitude together with an assumed tolerance of diaspores against drought and frost could explain the success of these species and their pantropical ranges. All three pantropical species of Diplasiolejeunea occur at rather low altitudes; however, this is not a general phenomenon for intercontinentally distributed liverworts. Plagiochila boryana is an example of a tropical American-African species occurring at high altitudes.

\subsubsection{Range formation and diversification}

Our study points to geographically restricted clades in Diplasiolejeunea, as well as to clades consisting of species groups with similar ecological and altitudinal preferences. This pattern is obviously the result of occasional long distance dispersal, frequent dispersal over short distances, local diversification, and perhaps also niche conservatism. It is also likely that extinction and recolonization processes contributed to the formation of current ranges. This combination of processes obviously shaped many liverwort ranges; examples come from the genera Bryopteris (Hartmann et al., 2006), Herbertus (Feldberg et al., 2007), Plagiochila (Heinrichs et al., 2006), Syzygiella (Feldberg et al., 2010) and others.

The observed patterns contradict a general panmixis hypothesis as well as Crum's (1972) hypothesis of bryophytes being "unmoving, unchanging sphinxes of the past" (Crum, 1972). Instead, they are commemorative of biogeographical patterns in angiosperms (Renner, 2004 and Bartish et al., 2011), although bryophyte species tend to have larger ranges. However, already Shaw (2001) pointed out that morphological uniformity of bryophytes belies complex underlying genetic and phylogenetic patterns. Since then, numerous molecular studies confirmed this hypothesis (Stech and Wagner, 2005, Grundmann et al., 2007, Shaw et al., 2008, and Ramaiya et al., 2010), accentuating that our understanding of speciation processes in bryophytes is still limited. In this regard, Diplasiolejeunea confirms the rule. 


\subsubsection{Perspectives}

The present study is the first comprehensive molecular phylogenetic investigation of a largely epiphyllous genus of liverworts. Despite their diminutiveness and the small size of many vouchers, we were able to include about fifty percent of the expected Diplasiolejeunea species diversity (Schäfer-Verwimp, 2006). Hence our topologies allow for a reclassification of the genus, and provide a framework for forthcoming monographic studies. Presently molecular studies of Diplasiolejeunea are hampered by the limited number of herbarium specimens suitable for DNA extraction. Future fieldwork will thus be essential to complete the phylogeny of Diplasiolejeunea; and to further elucidate the relationships in several critical complexes such as the andine $D$. pauckertii group and the $D$. pellucida-caribea complex.

\section{Acknowledgments}

We are grateful to the directors and curators of the herbaria EGR, G, JE, and PC for the loan of specimens including types. Thanks are due to Maarten Kappelle and Nelson Zamora, Instituto Nacional de Biodiversidad (INBio), for logistic support during fieldwork in Costa Rica, and Susanna León-Yánez and Santiago Yandún for logistic support in Ecuador. Fieldwork in Ecuador by the second author in the framework of the ABA-GAM project was funded by the German Research Foundation (grant LE 1826/4-1). The Diplasiolejeunea project was supported by the German Research Foundation (grants HE 3584/2 and 4) and scholarship No. 2010697001 granted to S.D. by China

Scholarship Council. This is publication number 78 from the Courant Research Centre Geobiology that is funded by the German Initiative of Excellence.

\section{References}

Ahonen, I., Muonen, J., Piippo, S., 2003. Inferring the phylogeny of Lejeuneaceae: a first appraisal of molecular data. Bryologist 106, 297-308.

Antonelli. A., Sanmartin. I., 2011. Why are there so many plant species in the Neotropics? Taxon 60: 403-414.

Bartish, I.V., Antonelli, A., Richardson, J.E., Swenson, U., 2011. Vicariance or long- 
distance dispersal: historical biogeography of the pantropical subfamily Chrysophylloideae (Sapotaceae). J. Biogeogr. 38, 177-190.

Benavides, J.C., Saste-De Jésus, 2011. Diversity and rarity of epiphyllous bryophytes in a superhumid tropical lowland forest of Chocó-Colombia. Cryptog., Bryol. 32, 119-133.

Cornelissen, J.H.C., Ter Steege, H., 1989. Distribution and ecology of epiphytic bryophytes and lichens in dry evergreen forest of Guyana. J. Trop. Ecol. 5, 131-150.

Crandall-Stotler, B., Stotler, R.E., Long, D.G., 2009. Phylogeny and classification of the Marchantiophyta. Edinburgh J. Bot. 66, 155-198.

Crum, H.A., 1972. The geographic origins of the mosses of North America's Eastern deciduous forest. J. Hattori Bot. Lab. 35, 269-298.

Dayrat, B., 2005. Towards integrative taxonomy. Biol. J. Linn. Soc. 85, 407-415.

De Queiroz, K., 2007. Species concepts and species delimitation. Syst. Biol. 56, 879886.

Devos, N., Vanderpoorten, A., 2009. Range disjunctions, speciation, and morphological transformation rates in the liverwort genus Leptoscyphus. Evolution 63, 779-791.

Feldberg, K., Hentschel, J., Wilson, R., Rycroft, D.S., Glenny, D., Heinrichs, J., 2007. Phylogenetic biogeography of the leafy liverwort Herbertus (Jungermanniales, Herbertaceae) based on nuclear and chloroplast DNA sequence data: correlation between genetic variation and geographical distribution. J. Biogeogr. 34, 688-698.

Feldberg, J., Váňa, J., Long, D.G., Shaw, J., Hentschel, J., Heinrichs, J., 2010. A phylogeny of Adelanthaceae (Jungermanniales, Marchantiophyta) based on nuclear and chloroplast DNA markers, with comments on classification, cryptic speciation and biogeography. Mol. Phylogenet. Evol. 55, 293-304. 
Forrest, L.L., Salazar Allen, N., Gudiño, J.A., Korpelainen, H., Long, D.G., 2011. Molecular and morphological evidence for distinct species in Dumortiera (Dumoerieraceae). Bryologist 114, 102-115.

Fuselier, L., Davison, P.G., Clements, M., Shaw, B., Devos, N., Heinrichs, J., Hentschel, J., Sabovljevic, M., Szövenyi, P., Schütte, S., Hofbauer, W., Shaw, A.J., 2009. Phylogeographic analyses reveal distinct lineages of Metzgeria furcata and $M$. conjugata (Metzgeriaceae) in Europe and North America. Biol. J. Linn. Soc. 98, 745756.

Goldman, N., 1993. Statistical tests of models of DNA substitution. J. Molec. Evol. 36, 182-198.

Givnish, T.J., Millam, K.C., Evans, T.M., Hall, J.C. Pires, J.C., Berry, P.E., Sytsma, K.J., 2004. Ancient vicariance or recent long-distance dispersal? Inferences about phylogeny and South American-African disjunctions in Rapateaceae and Bromeliaceae based on ndhF sequence data. Int. J. PI. Sci. 165(suppl), S35-S54.

Gradstein, S.R., 1997. The taxonomic diversity of epiphyllous bryophytes. Abstr. Bot. 21, $15-19$.

Gradstein, S.R., Churchill, S.P., Salazar-Allen, N., 2001. Guide to the Bryophytes of tropical America. Mem. New York Bot. Gard. 86, 1-577.

Gradstein, S.R., Ilkiu-Borges, A.L., Vanderpoorten, A., 2011. Habitat speciation triggers the evolution of unusual morphologies - the case of Cololejeunea stotleriana sp. nov. from Ecuador. Bryologist 114, 9-22.

Gradstein, S.R., Wilson, R., Ilkiu-Borges, A.L., Heinrichs, J., 2006. Phylogenetic relationships and neotenic evolution of Metzgeriopsis (Lejeuneaceae) based on chloroplast DNA sequences and morphology. Bot. J. Linn. Soc. 151, 293-308. 
Grolle, R., 1966. Über Diplasiolejeunea in Asien. Fedd. Repert. 73, 78-89.

Grolle, R., 1995. The Hepaticae and Anthocerotae of the East African Islands. An annotated catalogue. Bryophyt. Biblioth. 48, 1-178.

Grundmann, M., Ansell, S.W., Russel, S.J., Koch, M.A., Vogel, J.C., 2007. Genetic structure of the widespread and common Mediterranean bryophyte Pleurochaete squarrosa (Brid.) Lindb. - evidence from nuclear and plastidic DNA sequence variation and allozymes. Molec. Ecol. 16, 709-722.

Hall, T.A., 1999. BIOEDIT: a user-friendly biological sequence alignment editor and analysis program for Windows 95/98/NT. Nucleic Acids Symp. Ser. 41, 95-98.

Hartmann, F.A., Wilson, R., Gradstein, S.R., Schneider, H., Heinrichs, J., 2006. Testing hypotheses on species delimitations and disjunctions in the liverwort Bryopteris (Jungermanniopsida: Lejeuneaceae). Int. J. Plant Sci. 167, 1205-1214.

Heinrichs, J., Gradstein, S.R., Wilson, R., Schneider, H., 2005a. Towards a natural classification of liverworts (Marchantiophyta) based on the chloroplast gene rbcL. Cryptog. Bryol. 26, 131-150.

Heinrichs, J., Hentschel, J., Bombosch, A., Fiebig, A., Reise, J., Edelmann, M., Kreier, H.-P., Schäfer-Verwimp, A., Caspari, S., Schmidt, A.R., Zhu, R.-L., von Konrat, M., Shaw, B., Shaw, A.J., 2010. One species or at least eight? Delimitation and distribution of Frullania tamarisci (L.) Dumort. (Jungermanniopsida, Porellales) inferred from nuclear and chloroplast DNA markers. Molec. Phylogen. Evol. 56, 11051114.

Heinrichs, J., Hentschel, J., Feldberg, K., Bombosch, A., Schneider, H., 2009a. Phylogenetic biogeography and taxonomy of disjunctly distributed bryophytes. J. Syst. Evol. 47, 497-508. 
Heinrichs, J., Klugmann, F., Hentschel, J., Schneider, H., 2009b. DNA taxonomy, cryptic speciation and diversification of the Neotropical-African liverwort, Marchesinia brachiata (Lejeuneaceae, Porellales). Molec. Phylogenet. Evol. 53, 113-121.

Heinrichs, J., Kreier, H.-P., Feldberg, K., Schmidt, A.R., Zhu, R.L., Shaw, B., Shaw, A.J., Wissemann, V., 2011. Formalizing morphologically cryptic biological entities: New insights from DNA taxonomy, hybridization, and biogeography in the leafy liverwort Porella platyphylla (Jungermanniopsida, Porellales). Amer. J. Bot. 98, 1252-1262.

Heinrichs, J., Lindner, M., Gradstein, S.R., Groth, H., Buchbender, V., Solga, A., Fischer, E., 2005b. Origin and subdivision of Plagiochila (Jungermanniidae: Plagiochilaceae) in tropical Africa based on evidence from nuclear and chloroplast DNA sequences and morphology. Taxon 54, 317-333.

Heinrichs, J., Lindner, M., Groth, H., Hentschel, J., Feldberg, K., Renker, C, Engel, J.J., von Konrat, M., Long, D.G., Schneider, H., 2006. Goodbye or welcome Gondwana? insights into the phylogenetic biogeography of the leafy liverwort Plagiochila with a description of Proskauera, gen. nov. (Plagiochilaceae, Jungermanniales). PI. Syst. Evol. 258, 211-226.

Hennequin, S., Hovenkamp, P., Christenhusz, M.J.M., Schneider, H., 2010. Phylogenetics and biogeography of Nephrolepis - a tale of old settlers and young tramps. Bot. J. Linn. Soc. 164, 113-127.

Hentschel, J., von Konrat, M.J., Pócs, T., Schäfer-Verwimp, A., Shaw, A.J., Schneider, H., Heinrichs, J., 2009. Molecular insights into the phylogeny and subgeneric classification of Frullania Raddi (Frullaniaceae, Porellales). Molec. Phylogen. Evol. 52, 142-156.

Hillis, D.M., Bull, J.J., 1993. An empirical test of bootstrapping as a method for assessing the confidence in phylogenetic analysis. Syst. Biol. 42, 182-192. 
Holmgren, P.K., Holmgren, N.H., Barnett, N.C., 1990. Index Herbariorum. Part I: The Herbaria of the World (Regnum Veg. 120), eighth ed. New York Botanical Garden, New York.

Huelsenbeck, J.P., Ronquist, F., 2001. MRBAYES: Bayesian inference of phylogenetic trees. Bioinformatics 17, 754-755.

Felsenstein, J., 1985. Confidence limits on phylogenies: an approach using the bootstrap. Evolution 39, 783-791.

Kreier, H.-P., Feldberg, K., Mahr, F., Bombosch, A., Schmidt, A.R., Zhu, R.-L., von Konrat, M., Shaw, B., Shaw, A.J., Heinrichs, J., 2010. Phylogeny of the leafy liverwort Ptilidium: cryptic speciation and shared haplotypes between the Northern and Southern Hemispheres. Molec. Phylogen. Evol. 57, 1260-1267.

Kreier, H.-P., Rex, M., Weising, K., Kessler, M., Smith, A.R., Schneider, H., 2008. Inferring the diversification of the epiphytic fern genus Serpocaulon (Polypodiaceae) in South America using chloroplast sequences and amplified fragment length polymorphisms. PI. Syst. Evol. 274, 1-16.

Laenen, B., Désamoré, A., Devos, N., Shaw, A.J., Gonzáles-Mancebo, J.M., Carine, M.A., Vanderpoorten, A., 2011. Macaronesia: a source of hidden genetic diversity for post-glacial recolonization of western Europe in the leafy liverwort Radula lindenbergiana. J. Biogeogr. 38, 631-639.

Löbel, S., Rydin, H., 2010. Trade-offs and habitat constraints in the establishment of epiphytic bryophytes. Funct. Ecol. 24, 887-897.

Maddison, D.R., Maddison, W.P., 2004. Mesquite, version 2. Tucson, Arizona. Available at http://mesquiteproject.org

McLoughlin, S., 2001. The breakup history of Gondwana and its impact on pre-Cenozoic floristic provincialism. Austral. Syst. Bot. 49, 271-300. 
Mason-Gamer, R.J., Kellogg, E.A., 1996. Testing for phylogenetic conflict among molecular data sets in the tribe Triticeae (Gramineae). Syst. Biol. 45, 524-545.

Odrzykoski, I.J., Chudzinska, E., Szweykowski, J., 1996. The hybrid origin of the polyploid liverwort Pellia borealis. Genetica 98, 75-86.

Odrzykoski, I.J., Szweykowski, J., 1991. Genetic differentiation without concordant morphological divergence in the thallose liverwort Conocephalum conicum. Plant Syst. Evol. 178, 135-152.

Pennington, R.T., Lavin, M., Sarkinen T, Lewis GP, Klitgaard BB, Hughes CE 2010 Contrasting plant diversification histories within the Andean biodiversity hotspot. Proc. Nat. Acad. Sci USA 107, 13783-13787.

Pócs, T., 1996. Epiphyllous liverwort diversity at worldwide level and its threat and conservation. Anales Inst. Biol. Univ. Nac. Autón. México, Ser. Bot. 67, 109-127.

Pócs, T., 2006. New or little-known epiphyllous bryophytes, X. On two Neotropical Diplasiolejeunea species. Bryologist 109, 408-414.

Pócs, T., Schäfer-Verwimp, A., 2006. East African bryophytes, XXIII. Three new species of Diplasiolejeunea (Lejeuneaceae, Jungermanniopsida) from Madagascar. Cryptog., Bryol. 27, 439-452.

Pohjamo, M, Laaka-Lindberg, S, Ovaskainen, O, Korpelainen, H., 2006. Dispersal potential of spores and asexual propagules in the epixylic hepatic Anastrophyllum hellerianum. Evolutionary Ecology 20: 415-430.

Posada, D., 2008. jModelTest: Phylogenetic model averaging. Molec. Biol. Evol. 25, 1253-1256.

Rambaut, A., Drummond, A.J., 2003. Tracer V1.3. <http://evolve.zoo.ox.ac.uk>. 
Ramaiya, M., Johnston, M.G., Shaw, B., Heinrichs, J., Hentschel, J., von Konrat, M., Davison, P.G., Shaw, A.J., 2010. Morphologically cryptic biological species within the liverwort, Frullania asagrayana. Amer. J. Bot. 97, 1707-1718.

Renner, M.A.M., Brown, E.A., Wardle, G.M., 2011. The Lejeunea tumida group is positively paraphyletic (Lejeuneaceae: Jungermanniopsida). Austral. Syst. Bot. 24, 1018.

Renner, S., 2004. Plant dispersal across the tropical Atlantic by wind and sea currents. Int. J. PI. Sci. 165 (suppl.), S23-S33.

Reyes, D.M., 1982 [1983]. El género Diplasiolejeunea en Cuba. Acta Bot. Acad. Sci. Hung. 28, 145-180.

Schäfer-Verwimp, A., 2004. The genus Diplasiolejeunea (Lejeuneaceae, Marchantiopsida) in the tropical Andes, with description of two new species. Cryptog., Bryol. 25, 3-17.

Schäfer-Verwimp, A., 2005. Diplasiolejeunea riclefgrollei (Lejeuneaceae, Jungermanniopsida), a remarkable new species from Cuba. Cryptog., Bryol. 26, 37-40.

Schäfer-Verwimp, A., 2006. A new species of Diplasiolejeunea (Lejeuneaceae, Jungermanniopsida) from Sumatra, and a key for the genus in Asia. Herzogia 19, 239244.

Schäfer-Verwimp, A., Reiner-Drehwald, M.E., 2009. Some additions to the bryophyte flora of Guadeloupe, West Indies, and new synonyms in the genera Diplasiolejeunea and Lejeunea. Cryptog., Bryol. 30, 357-375.

Schuster, R.M., 1970. Studies on Hepaticae, XLIX-LIII. New Lejeuneaceae from Dominica and Jamaica. Bull. Torrey Bot. Club 97, 336-352. 
Schuster, R.M., 1980. The Hepaticae and Anthocerotae of North America, East of the Hundredth Meridian, Vol. IV. Columbia University Press, New York.

Shaw, A.J., 2001. Biogeographic patterns and cryptic speciation in bryophytes. J. Biogeogr. 28, 253-261.

Shaw, A.J., Boles, S., Shaw, B., 2008. A phylogenetic delimitation of the "Sphagnum subsecundum complex" (Sphagnaceae, Bryophyta). Amer. J. Bot. 95, 731-744.

Sonnleitner, M., Dullinger, S., Wanek, W., Zechmeister, H., 2009. Microclimatic patterns correlate with the distribution of epiphyllous bryophytes in a tropical lowland rain forest in Costa Rica. J. Trop. Ecol. 25, 321-330.

Stech, M., Wagner, D., 2005. Molecular relationships, biogeography, and evolution of Gondwanan Campylopus species (Dicranaceae, Bryopsida). Taxon 54, 377-382.

Sukkharak, P., Gradstein, S.R., Stech, M., 2011. Phylogeny, taxon circumscriptions and character evolution in the core Ptychanthoideae (Lejeuneaceae, Marchantiophyta). Taxon 60, 1607-1622.

Swofford, D.L., 2000. PAUP*, phylogenetic analyses using parsimony (* and other methods), version 4.01b10. Sinauer Associates, Sunderland, Massachusetts.

Tavaré, S., 1986. Some probabalistic and statistical problems on the analysis of DNA sequences. Lec. Math. Life Sci. 17, 57-86.

Tixier, P., 1985. Contribution à la connaicance des Cololejeunoideae. Bryophyt. Biblioth. 27, 1-439.

Vanderpoorten, A., Gradstein, S.R., Carine, M.A., Devos, N., 2010a. The ghosts of Gondwana and Laurasia in modern liverwort distributions. Biol. Rev. 85: 471-487. 
Vanderpoorten, A., Schäfer-Verwimp, A., Heinrichs, J., Devos, N., Long, D.G., 2010b. The taxonomy of the leafy liverwort genus Leptoscyphus (Lophocoleaceae) revisited. Taxon 59, 176-186.

Wachowiak, W., Bącziewicz, A., Chudzińska, E, Buczkowska, K., 2007. Cryptic speciation in liverworts - a case study in the Aneura pinguis complex. Bot. J. Linn. Soc. 155, 273-282.

Will, K.W., Mishler, B.D., Wheeler, Q.D., 2005. The perils of DNA barcoding and the need for integrative taxonomy. Syst. Biol. 54, 844-851.

Wilson, R., Gradstein, S.R., Schneider, H., Heinrichs, J., 2007a. Unravelling the phylogeny of Lejeuneaceae (Jungermanniopsida): evidence for four main lineages. Molec. Phylogen. Evol. 43, 270-282.

Wilson, R., Heinrichs, J., Hentschel, J., Gradstein, S.R., Schneider, H., 2007b. Steady diversification of derived liverworts under Tertiary climatic fluctuations. Biol. Lett. 3, 566-569.

Wolf, P.G., Schneider, H., Ranker, T.A., 2001. Geographic distributions of homosporous ferns: does dispersal obscure evidence of vicariance? J. Biogeogr. 28, 263-270.

Yu, J., Devos, N., Mayestyk, P., Shaw, A.J., 2010. Intercontinentally disjunct species are derived rather than relictual in the moss genus Daltonia (Bryophyta). Taxon 59, 459465.

Zachos, J., Pagani, M., Sloan, L., Thomas, L., Billups, K., 2001. Trends, rhythms and aberrations in global climate $65 \mathrm{Ma}$ to present. Science 292, 686-693.

van Zanten, B.O. 1978. Experimental studies on trans-oceanic long-range dispersal of moss spores in the Southern Hemisphere. J. Hattori Bot. Lab. 44, 455-482.

van Zanten, B.O., Gradstein, S.R., 1988. Experimental dispersal geography of 
Neotropical liverworts. Beih. Nova Hedwigia 90, 41-94.

Zartman, C.E., 2003. Habitat fragmentation impacts on epiphyllous bryophyte communities in central Amazonia. Ecology 84, 948-954.

Zhu, R.-L, So, M.-L., 2001. Epiphyllous liverworts of China. Nova Hedwigia Beih. 121, 1418.

Zwickl, D.J. 2006. Genetic algorithm approaches for the phylogenetic analysis of large biological sequence datasets under the maximum likelihood criterion. GARLI version 0.96 beta available online at http://www.nescent.org/informatics/. 
Table 1. Taxa used in the present study, including information about the origin of the studied material, voucher information, and the herbarium where the voucher is deposited, as well as GenBank accession numbers. Sequences in bold were obtained from GenBank. Herbarium acronyms follow Holmgren et al. (1990).

\begin{tabular}{|c|c|c|c|c|c|}
\hline \multirow[t]{2}{*}{ Taxon } & \multirow[t]{2}{*}{ Origin and altitude } & \multirow{2}{*}{$\begin{array}{l}\text { Collector and } \\
\text { herbarium }\end{array}$} & \multicolumn{3}{|c|}{ GenBank accession number } \\
\hline & & & nrlTS & $\operatorname{trnL}-\mathrm{F}$ & $r b c \mathrm{~L}$ \\
\hline $\begin{array}{l}\text { Cololejeunea } \\
\text { vitalana }\end{array}$ & Costa Rica & $\begin{array}{l}\text { Schäfer-Verwimp \& } \\
\text { Holz SV/H-0473/A } \\
\text { (GOET) }\end{array}$ & DQ987348 & DQ238573 & DQ238564 \\
\hline Colura acroloba & Fiji Isls. & Pócs 02361/BK (EGR) & DQ987306 & DQ238586 & DQ238565 \\
\hline $\begin{array}{l}\text { Diplasiolejeunea } \\
\text { alata }\end{array}$ & $\begin{array}{l}\text { Costa Rica, } \\
\text { Cartago, } 2460 \text { m }\end{array}$ & $\begin{array}{l}\text { Schäfer-Verwimp \& } \\
\text { Holz SV/H-0422 } \\
\text { (GOET) }\end{array}$ & JQ729355 & JQ729579 & JQ729471 \\
\hline D. alata & $\begin{array}{l}\text { Ecuador (I), } \\
\text { Pichincha, } 1980 \text { m }\end{array}$ & $\begin{array}{l}\text { Schäfer-Verwimp et al. } \\
24116 / A \text { (GOET) }\end{array}$ & JQ729353 & JQ729577 & JQ729469 \\
\hline D. alata & $\begin{array}{l}\text { Ecuador (II), } \\
\text { Zamora-Chinchipe, } \\
2750-2780 \mathrm{~m}\end{array}$ & $\begin{array}{l}\text { Schäfer-Verwimp \& } \\
\text { Preussing } 23311 \\
(\text { GOET) }\end{array}$ & JQ729354 & JQ729578 & JQ729470 \\
\hline D. alata & $\begin{array}{l}\text { Panama, Chiriqui, } \\
1740 \mathrm{~m}\end{array}$ & $\begin{array}{l}\text { Schäfer-Verwimp et al. } \\
30956 \text { (GOET) }\end{array}$ & JQ729352 & JQ729576 & JQ729468 \\
\hline D. andringitrae & $\begin{array}{l}\text { Madagascar (I), } \\
\text { Toamasina Prov., } \\
\text { 1080-1214 m }\end{array}$ & $\begin{array}{l}\text { Pócs et al. 9890/CT } \\
\text { (GOET, Paratype) }\end{array}$ & JQ729338 & JQ729561 & JQ729453 \\
\hline D. andringitrae & $\begin{array}{l}\text { Madagascar (II), } \\
\text { Andringitra Mts., } \\
750-1000 \mathrm{~m}\end{array}$ & $\begin{array}{l}\text { Pócs et al. 9472/AC } \\
\text { (EGR, Paratype) }\end{array}$ & JQ729339 & JQ729562 & JQ729454 \\
\hline D. armatiloba & $\begin{array}{l}\text { Guadeloupe, } \\
\text { Basse Terre, } \\
950 \mathrm{~m}\end{array}$ & $\begin{array}{l}\text { Schäfer-Verwimp \& } \\
\text { Verwimp 22580/C } \\
\text { (GOET) }\end{array}$ & JQ729388 & JQ729613 & JQ729505 \\
\hline D. borhidiana & Dominican & Schäfer-Verwimp \& & JQ729391 & JQ729616 & JQ729508 \\
\hline
\end{tabular}




\begin{tabular}{|c|c|c|c|c|c|}
\hline & $\begin{array}{l}\text { Republic, } \\
\text { Santiago, } 930 \mathrm{~m}\end{array}$ & $\begin{array}{l}\text { Verwimp 27214/C } \\
\text { (GOET) }\end{array}$ & & & \\
\hline D. brunnea & $\begin{array}{l}\text { Bolivia, } \\
\text { Cochabamba, } \\
195 \text { m }\end{array}$ & $\begin{array}{l}\text { Abrahamczyk } 29013 \\
\text { (GOET) }\end{array}$ & JQ729400 & JQ729624 & - \\
\hline D. brunnea & $\begin{array}{l}\text { Brazil, Mato } \\
\text { Grosso, } 320 \mathrm{~m}\end{array}$ & $\begin{array}{l}\text { Schäfer-Verwimp } \\
11380 \text { (GOET) }\end{array}$ & JQ729402 & JQ729626 & JQ729517 \\
\hline D. brunnea & $\begin{array}{l}\text { Dominican Rep., } \\
\text { Santiago, } 930 \mathrm{~m}\end{array}$ & $\begin{array}{l}\text { Schäfer-Verwimp \& } \\
\text { Verwimp 27206/A } \\
\text { (GOET) }\end{array}$ & JQ729399 & JQ729623 & JQ729515 \\
\hline D. brunnea & $\begin{array}{l}\text { Ecuador (I), } \\
\text { Zamora-Chinchipe, } \\
2002 \text { m }\end{array}$ & $\begin{array}{l}\text { Schäfer-Verwimp \& } \\
\text { Nebel 31968/A } \\
\text { (GOET) }\end{array}$ & JQ729406 & JQ729630 & JQ729520 \\
\hline D. brunnea & $\begin{array}{l}\text { Ecuador (II), Napo, } \\
\text { 400-450 m }\end{array}$ & $\begin{array}{l}\text { Schäfer-Verwimp \& } \\
\text { Nebel } 31704 \text { (GOET) }\end{array}$ & JQ729405 & JQ729629 & JQ729519 \\
\hline D. brunnea & $\begin{array}{l}\text { Ecuador (III), } \\
\text { Zamora-Chinchipe, } \\
1860 \mathrm{~m}\end{array}$ & $\begin{array}{l}\text { Schäfer-Verwimp \& } \\
\text { Preussing 23237/A } \\
\text { (GOET) }\end{array}$ & JQ729401 & JQ729625 & JQ729516 \\
\hline D. caribea & $\begin{array}{l}\text { Guadeloupe (I), } \\
\text { Basse Terre, } \\
450 \mathrm{~m}\end{array}$ & $\begin{array}{l}\text { Schäfer-Verwimp \& } \\
\text { Verwimp 22287/A } \\
\text { (GOET) }\end{array}$ & JQ729374 & JQ729598 & JQ729491 \\
\hline D. caribea & $\begin{array}{l}\text { Guadeloupe (II), } \\
\text { Basse Terre, } \\
600 \mathrm{~m}\end{array}$ & $\begin{array}{l}\text { Schäfer-Verwimp \& } \\
\text { Verwimp 22133/B } \\
\text { (GOET) }\end{array}$ & JQ729378 & JQ729602 & JQ729495 \\
\hline D. caribea & $\begin{array}{l}\text { Guadeloupe (III), } \\
\text { Basse Terre, } \\
950 \mathrm{~m}\end{array}$ & $\begin{array}{l}\text { Schäfer-Verwimp \& } \\
\text { Verwimp 22580/A } \\
\text { (GOET) }\end{array}$ & JQ729379 & JQ729603 & JQ729496 \\
\hline D. caribea & $\begin{array}{l}\text { Guadeloupe (IV), } \\
\text { Basse Terre, } \\
615 \mathrm{~m}\end{array}$ & $\begin{array}{l}\text { Schäfer-Verwimp \& } \\
\text { Verwimp 22172/A } \\
\text { (GOET) }\end{array}$ & JQ729380 & JQ729604 & JQ729497 \\
\hline D. cavifolia & $\begin{array}{l}\text { Brazil, Santa } \\
\text { Catarina, } 3 \mathrm{~m}\end{array}$ & $\begin{array}{l}\text { Schäfer-Verwimp \& } \\
\text { Verwimp } 13598\end{array}$ & JQ729415 & JQ729638 & - \\
\hline
\end{tabular}


(GOET)

D. cavifolia Dominica, M. Trois Schäfer-Verwimp \& JQ729422 JQ729645 -

Pitons, $1000 \mathrm{~m} \quad$ Verwimp 17812

(GOET)

D. cavifolia $\quad$ Dominican Rep. (I), Pócs \& Pócs 03145/M JQ729420 JQ729643 JQ729533 Mons. Noel, $955 \mathrm{~m} \quad$ (EGR)

D. cavifolia

Dominican Rep.

Schäfer-Verwimp \&

JQ729416 JQ729639 JQ729529

(II), Santiago,

Verwimp 27214/A

$930 \mathrm{~m}$

(GOET)

D. cavifolia

Ecuador,

Schäfer-Verwimp et a

JQ729417 JQ729640

JQ729530

Tungurahua, 24241/B (GOET)

$1540 \mathrm{~m}$

D. cavifolia

Fiji Isls., Central

Pócs 08035/H (EGR)

JQ729413 JQ729636 JQ729527

Viti Levu, 800 m

D. cavifolia

Guadeloupe (I),

Schäfer-Verwimp \&

JQ72942

JQ729644

JQ729534

Basse Terre,

Verwimp 22402/E

$780 \mathrm{~m}$

(GOET)

D. cavifolia

Guadeloupe (II),

Schäfer-Verwimp \&

JQ729423 JQ729646

JQ729535

Basse Terre,

Verwimp 22137/B

$743 \mathrm{~m}$

(GOET)

D. cavifolia

Guadeloupe (III),

Schäfer-Verwimp \&

JQ729419 JQ729642 JQ729532

Basse Terre,

Verwimp 22597

$900 \mathrm{~m}$

(GOET)

D. cavifolia

Indonesia,

Schäfer-Verwimp \&

JQ729410 JQ729633 JQ729524

Sumatra, $1580 \mathrm{~m}$

Verwimp 24923/B

(GOET)

D. cavifolia

Madagascar (I),

Pócs \& Zsabo

JQ729412 JQ729635 JQ729526

Andasive, $995 \mathrm{~m}$

9484/AE (EGR)

D. cavifolia

Madagascar (II),

Pócs \& Pócs 04118/CB JQ729414 JQ729637 JQ729528

Fianarantsoa Prov., (EGR)

865-1015 m

D. cavifolia

Malaysia (I),

Schäfer-Verwimp \&

JQ729411 JQ729634 JQ729525 


\begin{tabular}{|c|c|c|c|c|c|}
\hline & Pahang, $1280 \mathrm{~m}$ & $\begin{array}{l}\text { Verwimp 18584/B } \\
\text { (GOET) }\end{array}$ & & & \\
\hline D. cavifolia & $\begin{array}{l}\text { Malaysia (II), } \\
\text { Perak, } 1340 \mathrm{~m}\end{array}$ & $\begin{array}{l}\text { Schäfer-Verwimp \& } \\
\text { Verwimp 19036/A } \\
\text { (GOET) }\end{array}$ & JQ729418 & JQ729641 & JQ729531 \\
\hline D. cavifolia & $\begin{array}{l}\text { Panama, Prov. } \\
\text { Panama, } 970 \mathrm{~m}\end{array}$ & $\begin{array}{l}\text { Schäfer-Verwimp \& } \\
\text { Verwimp } 30738 \\
\text { (GOET) }\end{array}$ & JQ729424 & JQ729647 & - \\
\hline D. cavifolia & $\begin{array}{l}\text { Réunion, Piton de } \\
\text { la Fournaise, } \\
1030 \mathrm{~m}\end{array}$ & $\begin{array}{l}\text { Schäfer-Verwimp } \\
20385 \text { (GOET) }\end{array}$ & JQ729407 & JQ729631 & JQ729521 \\
\hline D. cavifolia & $\begin{array}{l}\text { Venezuela (I), } \\
\text { Bolivar, } 1370 \mathrm{~m}\end{array}$ & $\begin{array}{l}\text { Pócs et al. 0225EA } \\
\text { (EGR) }\end{array}$ & JQ729409 & JQ729632 & JQ729523 \\
\hline D. cavifolia & $\begin{array}{l}\text { Venezuela (II), } \\
\text { Bolivar, } 1370 \text { m }\end{array}$ & $\begin{array}{l}\text { Pócs et al. 0225EA-1 } \\
\text { (JE) }\end{array}$ & JQ729408 & - & JQ729522 \\
\hline D. cobrensis & $\begin{array}{l}\text { Madagascar, } \\
\text { Toamasina, } 4 \mathrm{~m}\end{array}$ & $\begin{array}{l}\text { Pócs et al. 9882/AE } \\
\text { (GOET) }\end{array}$ & JQ729337 & - & JQ729452 \\
\hline D. cobrensis & $\begin{array}{l}\text { Mayotte Isl, } \\
\text { Poroani, } 500 \mathrm{~m}\end{array}$ & $\begin{array}{l}\text { Pócs et al. 05092/R } \\
\text { (EGR) }\end{array}$ & JQ729336 & JQ729560 & JQ729451 \\
\hline D. cornuta & $\begin{array}{l}\text { Réunion (I), Cirque } \\
\text { de Salazie, } 1800 \mathrm{~m}\end{array}$ & $\begin{array}{l}\text { Schäfer-Verwimp et al. } \\
20012 \text { (GOET) }\end{array}$ & JQ729341 & JQ729564 & JQ729456 \\
\hline D. cornuta & $\begin{array}{l}\text { Réunion (II), Gîte } \\
\text { de Bélouve, } \\
1520 \text { m }\end{array}$ & Pócs 08063/E (EGR) & JQ729342 & JQ729565 & JQ729457 \\
\hline D. cubensis & $\begin{array}{l}\text { Guadeloupe (I), } \\
\text { Basse Terre, } \\
950 \mathrm{~m}\end{array}$ & $\begin{array}{l}\text { Schäfer-Verwimp \& } \\
\text { Verwimp 22580/B } \\
\text { (GOET) }\end{array}$ & JQ729392 & JQ729617 & JQ729509 \\
\hline D. cubensis & $\begin{array}{l}\text { Guadeloupe (II), } \\
\text { Basse Terre, } \\
1100 \mathrm{~m}\end{array}$ & $\begin{array}{l}\text { Schäfer-Verwimp \& } \\
\text { Verwimp 22388/C } \\
\text { (GOET) }\end{array}$ & JQ729393 & JQ729618 & JQ729510 \\
\hline D. eggersii & $\begin{array}{l}\text { Costa Rica, San } \\
\text { José, } 1600 \text { m }\end{array}$ & $\begin{array}{l}\text { Schäfer-Verwimp \& } \\
\text { Holz SV/H-0238 }\end{array}$ & JQ729368 & JQ729591 & JQ729484 \\
\hline
\end{tabular}


(GOET)

\begin{tabular}{|c|c|c|c|c|}
\hline ISII & Panama, Chiriqu & Schäfer-Verwimp \& & JQ729367 & JQ729590 JQ729483 \\
\hline
\end{tabular}

(GOET)

$\begin{array}{llllll}\text { D. erostrata } & \text { Ecuador (I), Loja, } & \text { Schäfer-Verwimp } & \text { JQ729426 } & \text { JQ729649 } & \text { JQ729537 } \\ & 2970 \mathrm{~m} & \text { 31769/B-1 (GOET) } & & & \\ \text { D. erostrata } & \text { Ecuador (II), Loja, } & \text { Schäfer-Verwimp \& } & \text { JQ729427 } & \text { JQ729650 } & \text { JQ729538 } \\ & 2970 \mathrm{~m} & \text { Nebel 31769 (GOET) } & & & \\ \text { D. erostrata } & \text { Ecuador (III), } & \text { Schäfer-Verwimp } & - & \text { JQ729651 } & \text { JQ729539 } \\ & \text { Zamora-Chinchipe, } & \text { 23335 (GOET) } & & & \\ & 2740 \mathrm{~m} & & & & \end{array}$
$\begin{array}{llll}\text { D. ingekarolae } \quad \text { Indonesia, } & \text { Schäfer-Verwimp \& } & \text { JQ729335 JQ729559 JQ729450 }\end{array}$
Sumatra, $1520 \mathrm{~m} \quad$ Verwimp 24906/B

(GOET, isotype)

\begin{tabular}{|c|c|c|}
\hline $\begin{array}{l}\text { D. involuta ssp. } \\
\text { andicola }\end{array}$ & $\begin{array}{l}\text { Ecuador (I), Loja, } \\
3050 \mathrm{~m}\end{array}$ & $\begin{array}{l}\text { Schäfer-Verwimp \& } \\
\text { Preussing } 23288\end{array}$ \\
\hline
\end{tabular}

(GOET)

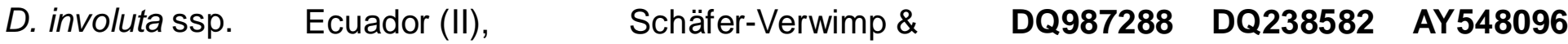 andicola Zamora-Chinchipe, Preussing 23508 $2860 \mathrm{~m} \quad$ (GOET)

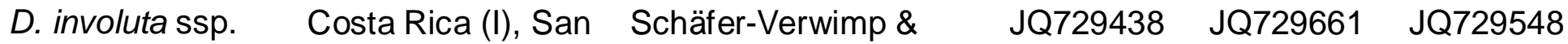
involuta José, $3400 \mathrm{~m} \quad \mathrm{Holz}$ SV/H-0147/A

(GOET)

\begin{tabular}{|c|c|c|c|c|c|}
\hline $\begin{array}{l}\text { D. involuta ssp. } \\
\text { involuta }\end{array}$ & $\begin{array}{l}\text { Costa Rica (II), } \\
\text { Cartago, } 2500 \text { m }\end{array}$ & $\begin{array}{l}\text { Morales \& Blanco 24/2 } \\
\text { (GOET) }\end{array}$ & JQ729441 & JQ729664 & JQ729550 \\
\hline $\begin{array}{l}\text { D. involuta ssp. } \\
\text { involuta }\end{array}$ & $\begin{array}{l}\text { Dominican Rep., } \\
\text { Cordillera Central, } \\
2170-2200 \text { m }\end{array}$ & $\begin{array}{l}\text { Schäfer-Verwimp \& } \\
\text { Verwimp 26680/B } \\
\text { (GOET) }\end{array}$ & JQ729437 & JQ729660 & JQ729547 \\
\hline $\begin{array}{l}\text { D. involuta ssp. } \\
\text { involuta }\end{array}$ & $\begin{array}{l}\text { Ecuador, Zamora- } \\
\text { Chinchipe, } 2650 \text { m }\end{array}$ & Mandl B6 (GOET) & JQ729439 & JQ729662 & JQ729670 \\
\hline $\begin{array}{l}\text { D. involuta ssp. } \\
\text { involuta }\end{array}$ & $\begin{array}{l}\text { Panama, Bocas } \\
\text { del Toro, } 3200 \mathrm{~m}\end{array}$ & $\begin{array}{l}\text { De Gracia et al. } 376 \\
\text { (GOET) }\end{array}$ & JQ729440 & JQ729663 & JQ729549 \\
\hline
\end{tabular}




\begin{tabular}{|c|c|c|c|c|c|}
\hline D. johnsonii & $\begin{array}{l}\text { Dominican Rep., } \\
\text { La Vega, } 1945 \text { m }\end{array}$ & $\begin{array}{l}\text { Pócs \& Pócs 03150/T } \\
\text { (EGR) }\end{array}$ & JQ729364 & JQ729587 & JQ729480 \\
\hline D. johnsonii & $\begin{array}{l}\text { Ecuador, Zamora- } \\
\text { Chinchipe, } 1060 \text { m }\end{array}$ & $\begin{array}{l}\text { Schäfer-Verwimp \& } \\
\text { Preussing 23426/A } \\
(\text { GOET) }\end{array}$ & JQ729363 & JQ729586 & JQ729479 \\
\hline D. jovet-astiae & $\begin{array}{l}\text { Malaysia (I), } \\
\text { Pahang, } 1640 \mathrm{~m}\end{array}$ & $\begin{array}{l}\text { Schäfer-Verwimp \& } \\
\text { Verwimp 18902/B } \\
\text { (GOET) }\end{array}$ & JQ729672 & JQ729556 & JQ729447 \\
\hline D. jovet-astiae & $\begin{array}{l}\text { Malaysia (II), } \\
\text { Pahang, } 1300 \text { m }\end{array}$ & $\begin{array}{l}\text { Schäfer-Verwimp \& } \\
\text { Verwimp 18620/C } \\
\text { (GOET) }\end{array}$ & JQ729333 & JQ729557 & JQ729448 \\
\hline D. kraussiana & $\begin{array}{l}\text { Madagascar, } \\
\text { Fianarantsoa Prov., } \\
1700-1750 \mathrm{~m}\end{array}$ & $\begin{array}{l}\text { Pócs et al.04115/CA } \\
\text { (GOET) }\end{array}$ & JQ729348 & JQ729572 & JQ729463 \\
\hline D. leiocarpa & $\begin{array}{l}\text { Guadeloupe (I), } \\
\text { Basse Terre, } \\
1170 \mathrm{~m}\end{array}$ & $\begin{array}{l}\text { Schäfer-Verwimp \& } \\
\text { Verwimp } 22384 \\
\text { (GOET) }\end{array}$ & JQ729386 & JQ729610 & - \\
\hline D. leiocarpa & $\begin{array}{l}\text { Guadeloupe (II), } \\
\text { Basse Terre, } \\
1160 \mathrm{~m}\end{array}$ & $\begin{array}{l}\text { Schäfer-Verwimp \& } \\
\text { Verwimp } 22385 \\
\text { (GOET) }\end{array}$ & JQ729387 & JQ729611 & JQ729503 \\
\hline D. leiocarpa & $\begin{array}{l}\text { Guadeloupe (III), } \\
\text { Basse Terre, } \\
670 \mathrm{~m}\end{array}$ & $\begin{array}{l}\text { Schäfer-Verwimp \& } \\
\text { Verwimp } 22143 \\
\text { (GOET) }\end{array}$ & JQ729674 & JQ729612 & JQ729504 \\
\hline D. malleiformis & Dominica, $450 \mathrm{~m}$ & $\begin{array}{l}\text { Schäfer-Verwimp } \\
\text { 17784/B (GOET) }\end{array}$ & JQ729397 & JQ729622 & - \\
\hline D. malleiformis & $\begin{array}{l}\text { Guadeloupe (I), } \\
\text { Basse Terre, } \\
400 \mathrm{~m}\end{array}$ & $\begin{array}{l}\text { Schäfer-Verwimp \& } \\
\text { Verwimp } 22496 \\
\text { (GOET) }\end{array}$ & JQ729394 & JQ729619 & JQ729511 \\
\hline D. malleiformis & $\begin{array}{l}\text { Guadeloupe (II), } \\
\text { Basse Terre, } \\
650 \mathrm{~m}\end{array}$ & $\begin{array}{l}\text { Schäfer-Verwimp \& } \\
\text { Verwimp 22300/C } \\
\text { (GOET) }\end{array}$ & JQ729395 & JQ729620 & JQ729512 \\
\hline D. malleiformis & Guadeloupe (III), & Schäfer-Verwimp \& & JQ729396 & JQ729621 & JQ729513 \\
\hline
\end{tabular}




\begin{tabular}{|c|c|c|c|c|c|}
\hline & $\begin{array}{l}\text { Basse Terre, } \\
615 \mathrm{~m}\end{array}$ & $\begin{array}{l}\text { Verwimp 22172/B } \\
\text { (GOET) }\end{array}$ & & & \\
\hline D. malleiformis & $\begin{array}{l}\text { Guadeloupe (IV), } \\
\text { Basse Terre, } \\
700 \mathrm{~m}\end{array}$ & $\begin{array}{l}\text { Schäfer-Verwimp \& } \\
\text { Verwimp } 22328 \\
\text { (GOET) }\end{array}$ & JQ729398 & - & JQ729514 \\
\hline D. ornata & $\begin{array}{l}\text { Madagascar, } \\
\text { Tomasina Prov., } \\
\text { 220-300 m }\end{array}$ & $\begin{array}{l}\text { Pócs \& Szabó 9878/F } \\
\text { (GOET) }\end{array}$ & JQ729340 & JQ729563 & JQ729455 \\
\hline D. papilionacea & $\begin{array}{l}\text { Ecuador, Napo, } \\
1970 \mathrm{~m}\end{array}$ & $\begin{array}{l}\text { Schäfer-Verwimp et al. } \\
\text { 24212/A (GOET) }\end{array}$ & JQ729362 & JQ729585 & JQ729478 \\
\hline D. patelligera & $\begin{array}{l}\text { Malaysia, Pahang, } \\
1460 \mathrm{~m}\end{array}$ & $\begin{array}{l}\text { Schäfer-Verwimp \& } \\
\text { Verwimp 18802/A } \\
\text { (GOET) }\end{array}$ & JQ729334 & JQ729558 & JQ729449 \\
\hline D. pauckertii & $\begin{array}{l}\text { Brazil, Rio de } \\
\text { Janeiro, } 2340 \mathrm{~m}\end{array}$ & $\begin{array}{l}\text { Schäfer-Verwimp \& } \\
\text { Verwimp } 15022 \\
\text { (GOET) }\end{array}$ & JQ729432 & JQ729655 & JQ729544 \\
\hline D. pauckertii & $\begin{array}{l}\text { Costa Rica, } \\
\text { Cartago, } 2460 \text { m }\end{array}$ & $\begin{array}{l}\text { Schäfer-Verwimp \& } \\
\text { Holz SV/H-0418 } \\
\text { (GOET) }\end{array}$ & JQ729434 & JQ729657 & - \\
\hline D. pauckertii & $\begin{array}{l}\text { Ecuador (I), } \\
\text { Zamora-Chinchipe, } \\
1880 \mathrm{~m}\end{array}$ & $\begin{array}{l}\text { Schäfer-Verwimp \& } \\
\text { Preussing 23219/B } \\
\text { (GOET) }\end{array}$ & JQ729435 & JQ729658 & JQ729545 \\
\hline D. pauckertii & $\begin{array}{l}\text { Ecuador (II), } \\
\text { Zamora-Chinchipe, } \\
1860 \mathrm{~m}\end{array}$ & $\begin{array}{l}\text { Schäfer-Verwimp \& } \\
\text { Preussing 23528/A } \\
\text { (GOET) }\end{array}$ & JQ729436 & JQ729659 & JQ729546 \\
\hline D. pauckertii & $\begin{array}{l}\text { Ecuador (III), } \\
\text { Zamora-Chinchipe, } \\
2500 \mathrm{~m}\end{array}$ & Mandl A7 (GOET) & JQ729433 & JQ729656 & - \\
\hline D. pauckertii & $\begin{array}{l}\text { Ecuador (IV), } \\
\text { Carchi, } 3700 \mathrm{~m}\end{array}$ & $\begin{array}{l}\text { Schäfer-Verwimp et al. } \\
\text { 24383/D (GOET) }\end{array}$ & JQ729428 & JQ729669 & JQ729540 \\
\hline D. pauckertii & $\begin{array}{l}\text { Panama (I), Bocas } \\
\text { del Toro, } 3335 \mathrm{~m}\end{array}$ & $\begin{array}{l}\text { De Gracia et al. } 338 \\
\text { (GOET) }\end{array}$ & JQ729429 & JQ729652 & JQ729541 \\
\hline
\end{tabular}




\begin{tabular}{|c|c|c|c|c|c|}
\hline D. pauckertii & $\begin{array}{l}\text { Panama (II), } \\
\text { Chiriqui, } 2600 \mathrm{~m}\end{array}$ & $\begin{array}{l}\text { Schäfer-Verwimp \& } \\
\text { Verwimp } 30921 \\
\text { (GOET) }\end{array}$ & JQ729430 & JQ729653 & JQ729542 \\
\hline D. pauckertii & $\begin{array}{l}\text { Panama (III), } \\
\text { Chiriqui, } 2600 \mathrm{~m}\end{array}$ & $\begin{array}{l}\text { Schäfer-Verwimp \& } \\
\text { Verwimp } 30908 \\
\text { (GOET) }\end{array}$ & JQ729431 & JQ729654 & JQ729543 \\
\hline D. pellucida & $\begin{array}{l}\text { Brazil, São Paulo, } \\
570 \text { m }\end{array}$ & $\begin{array}{l}\text { Schäfer-Verwimp \& } \\
\text { Verwimp 11234/A } \\
\text { (GOET) }\end{array}$ & JQ729376 & JQ729600 & JQ729493 \\
\hline D. pellucida & $\begin{array}{l}\text { Ecuador, } \\
\text { Pichincha, } 1380 \text { m }\end{array}$ & $\begin{array}{l}\text { Schäfer-Verwimp et al. } \\
24134 \text { (GOET) }\end{array}$ & JQ729383 & JQ729607 & JQ729500 \\
\hline D. pellucida & $\begin{array}{l}\text { French Guiana, } \\
\text { Kaw Mts., } 300 \text { m }\end{array}$ & Holz FG00-24 (GOET) & JQ729382 & JQ729606 & JQ729499 \\
\hline D. pellucida & $\begin{array}{l}\text { Panama, Chiriqui, } \\
1670 \mathrm{~m}\end{array}$ & $\begin{array}{l}\text { Schäfer-Verwimp \& } \\
\text { Verwimp 30936/A } \\
\text { (GOET) }\end{array}$ & JQ729384 & JQ729608 & JQ729501 \\
\hline D. pellucida & $\begin{array}{l}\text { Venezuela (I), } \\
\text { Bolivar, } 1340 \mathrm{~m}\end{array}$ & $\begin{array}{l}\text { Pócs et al. 00227/CO } \\
(E G R)\end{array}$ & JQ729377 & JQ729601 & JQ729494 \\
\hline D. pellucida & $\begin{array}{l}\text { Venezuela (II), } \\
\text { Bolivar, } 1340 \mathrm{~m}\end{array}$ & $\begin{array}{l}\text { Pócs et al. 00227/CG } \\
\text { (EGR) }\end{array}$ & JQ729385 & JQ729609 & JQ729502 \\
\hline D. plicatiloba & $\begin{array}{l}\text { Australia, } \\
\text { Tasmania, } 750 \mathrm{~m}\end{array}$ & $\begin{array}{l}\text { Pócs \& Pócs 0057/R } \\
\text { (EGR) }\end{array}$ & JQ729332 & JQ729555 & - \\
\hline D. plicatiloba & $\begin{array}{l}\text { New Zealand, } \\
\text { South Isl., 750- } \\
850 \mathrm{~m}\end{array}$ & $\begin{array}{l}\text { Schäfer-Verwimp \& } \\
\text { Verwimp } 14246 \\
\text { (GOET) }\end{array}$ & JQ729671 & JQ729554 & JQ729446 \\
\hline D. pluridentata & $\begin{array}{l}\text { Costa Rica, San } \\
\text { José, } 3400 \text { m }\end{array}$ & $\begin{array}{l}\text { Schäfer-Verwimp \& } \\
\text { Holz SV/H-0147/B } \\
\text { (GOET) }\end{array}$ & JQ729445 & JQ729668 & JQ729553 \\
\hline D. pluridentata & $\begin{array}{l}\text { Ecuador, Zamora- } \\
\text { Chinchipe, } 2220 \text { m }\end{array}$ & $\begin{array}{l}\text { Schäfer-Verwimp \& } \\
\text { Preussing 23366/A } \\
\text { (GOET) }\end{array}$ & JQ729444 & JQ729667 & JQ729552 \\
\hline D. pluridentata & Ecuador, Zamora- & Sauer \& Gradstein & JQ729443 & JQ729666 & - \\
\hline
\end{tabular}




\begin{tabular}{|c|c|c|c|c|c|}
\hline & Chinchipe, $2200 \mathrm{~m}$ & MS-E-143 (GOET) & & & \\
\hline D. pocsii & $\begin{array}{l}\text { Ecuador (I), } \\
\text { Zamora-Chinchipe, } \\
2550 \mathrm{~m}\end{array}$ & $\begin{array}{l}\text { Schäfer-Verwimp \& } \\
\text { Nebel } 32080 \text { (GOET) }\end{array}$ & JQ729389 & JQ729614 & JQ729506 \\
\hline D. pocsii & $\begin{array}{l}\text { Ecuador (II), } \\
\text { Zamora-Chinchipe, } \\
2780 \mathrm{~m}\end{array}$ & $\begin{array}{l}\text { Schäfer-Verwimp \& } \\
\text { Preussing } 23320 \\
\text { (GOET) }\end{array}$ & JQ729390 & JQ729615 & JQ729507 \\
\hline D. ranomafanae & $\begin{array}{l}\text { Madagascar, } \\
\text { Fianarantsoa Prov., } \\
1080-1160 \mathrm{~m}\end{array}$ & $\begin{array}{l}\text { Pócs 04129/Y, } \\
\text { Paratype (GOET) }\end{array}$ & JQ729343 & JQ729566 & JQ729458 \\
\hline D. replicata & $\begin{array}{l}\text { Brazil, Rio de } \\
\text { Janeiro, } 2420 \mathrm{~m}\end{array}$ & $\begin{array}{l}\text { Schäfer-Verwimp \& } \\
\text { Verwimp } 15032 \\
\text { (GOET) }\end{array}$ & JQ729361 & JQ729584 & JQ729477 \\
\hline D. replicata & $\begin{array}{l}\text { Costa Rica, San } \\
\text { José, } 2100 \mathrm{~m}\end{array}$ & $\begin{array}{l}\text { Schäfer-Verwimp \& } \\
\text { Holz SV/H-0246/C } \\
\text { (GOET) }\end{array}$ & JQ729356 & JQ729580 & JQ729472 \\
\hline D. replicata & $\begin{array}{l}\text { Ecuador (I), } \\
\text { Pichincha, } 2300 \text { m }\end{array}$ & $\begin{array}{l}\text { Schäfer-Verwimp et al. } \\
24523 \text { (GOET) }\end{array}$ & JQ729357 & JQ729581 & JQ729473 \\
\hline D. replicata & $\begin{array}{l}\text { Ecuador (II), } \\
\text { Zamora-Chinchipe, } \\
2900 \mathrm{~m}\end{array}$ & $\begin{array}{l}\text { Schäfer-Verwimp \& } \\
\text { Preussing 23496/B } \\
\text { (GOET) }\end{array}$ & JQ729360 & JQ729583 & JQ729476 \\
\hline D. replicata & $\begin{array}{l}\text { Panama, Chiriqui, } \\
1880 \mathrm{~m}\end{array}$ & $\begin{array}{l}\text { Schäfer-Verwimp \& } \\
\text { Verwimp } 30983 \\
\text { (GOET) }\end{array}$ & JQ729359 & JQ729582 & JQ729475 \\
\hline D. replicata & $\begin{array}{l}\text { Venezuela, Mérida, } \\
\text { 3090-3200 m }\end{array}$ & $\begin{array}{l}\text { Léon \& Pócs 9707/BG } \\
\text { (EGR) }\end{array}$ & JQ729358 & - & JQ729474 \\
\hline D. rudolphiana & $\begin{array}{l}\text { Brazil, São Paulo, } \\
150 \text { m }\end{array}$ & Lüth 3416 (GOET) & JQ729373 & JQ729597 & JQ729490 \\
\hline D. rudolphiana & $\begin{array}{l}\text { Dominican Rep., } \\
\text { Santiago, } 930 \text { m }\end{array}$ & $\begin{array}{l}\text { Schäfer-Verwimp \& } \\
\text { Verwimp 27214/B } \\
\text { (GOET) }\end{array}$ & JQ729371 & JQ729595 & JQ729488 \\
\hline D. rudolphiana & Guadeloupe, & Schäfer-Verwimp \& & JQ729370 & JQ729594 & JQ729487 \\
\hline
\end{tabular}




\begin{tabular}{|c|c|c|c|c|c|}
\hline & $\begin{array}{l}\text { Basse Terre, } \\
180 \mathrm{~m}\end{array}$ & $\begin{array}{l}\text { Verwimp 22512/B } \\
\text { (GOET) }\end{array}$ & & & \\
\hline D. rudolphiana & $\begin{array}{l}\text { Madagascar (I), } \\
\text { Toamasina Prov., } \\
10 \mathrm{~m}\end{array}$ & $\begin{array}{l}\text { Pócs \& Szabo 9887/P } \\
\text { (GOET) }\end{array}$ & - & JQ729592 & JQ729485 \\
\hline D. rudolphiana & $\begin{array}{l}\text { Madagascar (II), } \\
\text { Toamasina Prov., } \\
4 \mathrm{~m}\end{array}$ & $\begin{array}{l}\text { Pócs et al. 9882/AE } \\
\text { (pp.) (EGR) }\end{array}$ & JQ729372 & JQ729596 & JQ729489 \\
\hline D. rudolphiana & $\begin{array}{l}\text { Panama, } \\
\text { Veraguas, } 850 \mathrm{~m}\end{array}$ & $\begin{array}{l}\text { Schäfer-Verwimp \& } \\
\text { Verwimp } 30843 \\
\text { (GOET) }\end{array}$ & JQ729369 & JQ729593 & JQ729486 \\
\hline D. unidentata & $\begin{array}{l}\text { Guadeloupe (I), } \\
\text { Basse Terre, } \\
400 \mathrm{~m}\end{array}$ & $\begin{array}{l}\text { Schäfer-Verwimp \& } \\
\text { Verwimp 22500/A } \\
\text { (GOET) }\end{array}$ & JQ729365 & JQ729588 & JQ729481 \\
\hline D. unidentata & $\begin{array}{l}\text { Guadeloupe (II), } \\
\text { Basse Terre, } \\
615 \mathrm{~m}\end{array}$ & $\begin{array}{l}\text { Schäfer-Verwimp \& } \\
\text { Verwimp 22168/A } \\
\text { (GOET) }\end{array}$ & JQ729366 & JQ729589 & JQ729482 \\
\hline D. villaumei & $\begin{array}{l}\text { Kenya (I), Coast } \\
\text { Prov., 1980- } \\
2210 \mathrm{~m}\end{array}$ & $\begin{array}{l}\text { Pócs et al. 04042/AP } \\
(E G R)\end{array}$ & JQ729349 & JQ729573 & JQ729464 \\
\hline D. villaumei & $\begin{array}{l}\text { Kenya (II), Coast } \\
\text { Prov., 1980- } \\
2210 \mathrm{~m}\end{array}$ & $\begin{array}{l}\text { Pócs et al. 04042/Q } \\
\text { (EGR) }\end{array}$ & JQ729350 & JQ729575 & JQ729466 \\
\hline D. villaumei & $\begin{array}{l}\text { Kenya (III) Coast } \\
\text { Prov., 1980- } \\
2210 \mathrm{~m}\end{array}$ & $\begin{array}{l}\text { Pócs et al. 04042/QR } \\
\text { (EGR) }\end{array}$ & JQ729351 & - & JQ729467 \\
\hline D. villaumei & $\begin{array}{l}\text { Madagascar, Prov. } \\
\text { Antananarivo, } \\
1500 \mathrm{~m}\end{array}$ & $\begin{array}{l}\text { Pócs et al. 9851/Z } \\
\text { (EGR) }\end{array}$ & - & JQ729574 & JQ729465 \\
\hline D. zakiae & $\begin{array}{l}\text { Madagascar (I), } \\
\text { NE Andasive, } \\
1000 \mathrm{~m}\end{array}$ & $\begin{array}{l}\text { Pócs \& Szabó 9486/K } \\
\text { (GOET) }\end{array}$ & JQ729345 & JQ729568 & - \\
\hline
\end{tabular}




\begin{tabular}{|c|c|c|c|c|c|}
\hline D. zakiae & $\begin{array}{l}\text { Madagascar (II), } \\
\text { NE Andasive, } \\
1000 \mathrm{~m}\end{array}$ & $\begin{array}{l}\text { Vojtkó \& Pócs 9486/S } \\
\text { (EGR) }\end{array}$ & JQ729673 & JQ729570 & JQ729461 \\
\hline D. zakiae & $\begin{array}{l}\text { Madagascar (III), } \\
\text { Toamasina Prov., } \\
900-970 \mathrm{~m}\end{array}$ & $\begin{array}{l}\text { Pócs et al. 9889/BA } \\
\text { (GOET) }\end{array}$ & JQ729344 & JQ729567 & JQ729459 \\
\hline D. zakiae & $\begin{array}{l}\text { Madagascar (IV), } \\
\text { NE Andasibe, } \\
995 \mathrm{~m}\end{array}$ & Vojtkó 9484/AA (EGR) & JQ729346 & JQ729569 & JQ729460 \\
\hline D. zakiae & $\begin{array}{l}\text { Madagascar (V), } \\
\text { NE Andasibe, } \\
995 \text { m }\end{array}$ & $\begin{array}{l}\text { Pócs \& Szabó } \\
\text { 9484/AF (EGR) }\end{array}$ & JQ729347 & JQ729571 & JQ729462 \\
\hline D. spec. nov. I & $\begin{array}{l}\text { Ecuador, Zamora- } \\
\text { Chinchipe, } 2460 \text { m }\end{array}$ & $\begin{array}{l}\text { Schäfer-Verwimp \& } \\
\text { Preussing 23476/A } \\
\text { (GOET) }\end{array}$ & JQ729425 & JQ729648 & JQ729536 \\
\hline D. spec. nov. II & $\begin{array}{l}\text { Ecuador, Loja, } \\
2850 \mathrm{~m}\end{array}$ & $\begin{array}{l}\text { Schäfer-Verwimp \& } \\
\text { Nebel 31834/A } \\
\text { (GOET) }\end{array}$ & JQ729404 & JQ729628 & JQ729518 \\
\hline D. spec. nov. III & $\begin{array}{l}\text { Costa Rica, San } \\
\text { José, } 2330 \text { m }\end{array}$ & $\begin{array}{l}\text { Schäfer-Verwimp \& } \\
\text { Holz SV/H-0473/B } \\
\text { (GOET) }\end{array}$ & JQ729403 & JQ729627 & - \\
\hline D. spec. nov. IV & $\begin{array}{l}\text { Ecuador, Zamora- } \\
\text { Chinchipe, } 2180 \mathrm{~m}\end{array}$ & $\begin{array}{l}\text { Schäfer-Verwimp \& } \\
\text { Preussing 23364/A } \\
\text { (GOET) }\end{array}$ & JQ729381 & JQ729605 & JQ729498 \\
\hline D. spec. nov. $\mathrm{V}$ & $\begin{array}{l}\text { Ecuador, Zamora- } \\
\text { Chinchipe, } 850 \text { m }\end{array}$ & $\begin{array}{l}\text { Schäfer-Verwimp \& } \\
\text { Nebel } 32094 \text { (GOET) }\end{array}$ & & & \\
\hline
\end{tabular}




\section{Table 2. Morphological character states and ecological preferences of the investigated taxa as mapped onto the MP topology (Fig. 1).}

Morphological character states and occurences of the investigated taxa as mapped onto the MP topology (Fig. 1)

\begin{tabular}{|c|c|}
\hline \multirow[t]{2}{*}{ 1. Leaf margin } & with border of hyaline cells \\
\hline & without border of hyaline cells \\
\hline \multirow[t]{2}{*}{ 2. Ventral leaf margin } & involute (inflexed) from lobule to leaf apex \\
\hline & plane \\
\hline \multirow[t]{2}{*}{ 3. Ocelli } & present \\
\hline & lacking \\
\hline \multirow{3}{*}{$\begin{array}{l}\text { 4. T-like first tooth } \\
\text { on lobule }\end{array}$} & consistently present \\
\hline & occasionally to frequently present \\
\hline & lacking \\
\hline \multirow[t]{3}{*}{ 5. Lobule shape } & Lobule strongly inflated throughout, upper margin inrolled (inflexed) \\
\hline & Lobule inflated (at least in part), upper margin not or only narrowly inflexed \\
\hline & Lobule (+/-) flat, upper margin flat or narrowly inflexed) \\
\hline \multirow[t]{5}{*}{ 6. Underleaf lobes } & triangular, acute, sinus $(120-) 150-180^{\circ}$, margin not crenulate \\
\hline & triangular, acute, sinus $90-120\left(-150^{\circ}\right)$, margin not crenulate \\
\hline & +/- ovate, apex rounded to narrowly obtuse, margin not crenulate \\
\hline & +/- ovate, apex acute (to narrowly obtuse), margin not crenulate \\
\hline & lanceolate to narrowly ovate, margin $+/$ - crenulate \\
\hline \multirow[t]{3}{*}{ 7. Gender distribution } & dioecious \\
\hline & monoecious \\
\hline & dioecious or monoecious \\
\hline \multirow[t]{2}{*}{ 8. Gemmae } & present \\
\hline & lacking \\
\hline \multirow{3}{*}{ 9. occurrences } & epiphytic (occasionally epiphyllous) \\
\hline & epiphyllous (occasionally epiphytic) \\
\hline & $+/$ - equally often epiphytic or epiphyllous \\
\hline
\end{tabular}




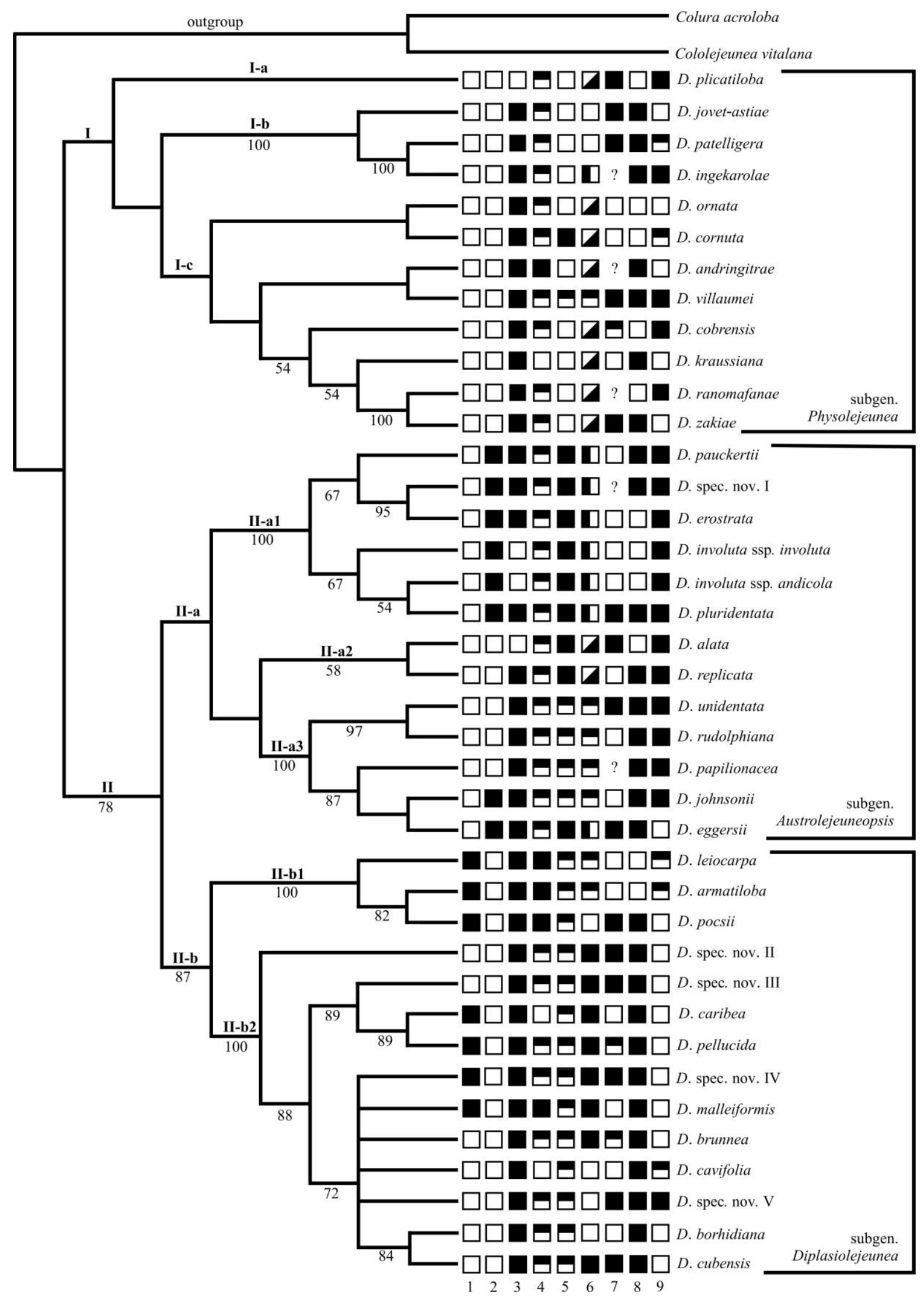

Fig. 1. Rooted strict consensus of 4 most parsimonious trees recovered during heuristic searches of the reduced combined dataset. Bootstrap percentage values $>50$ are indicated at branches. Morphological character states and ecological preferences (Table2) are mapped on to the tree. 


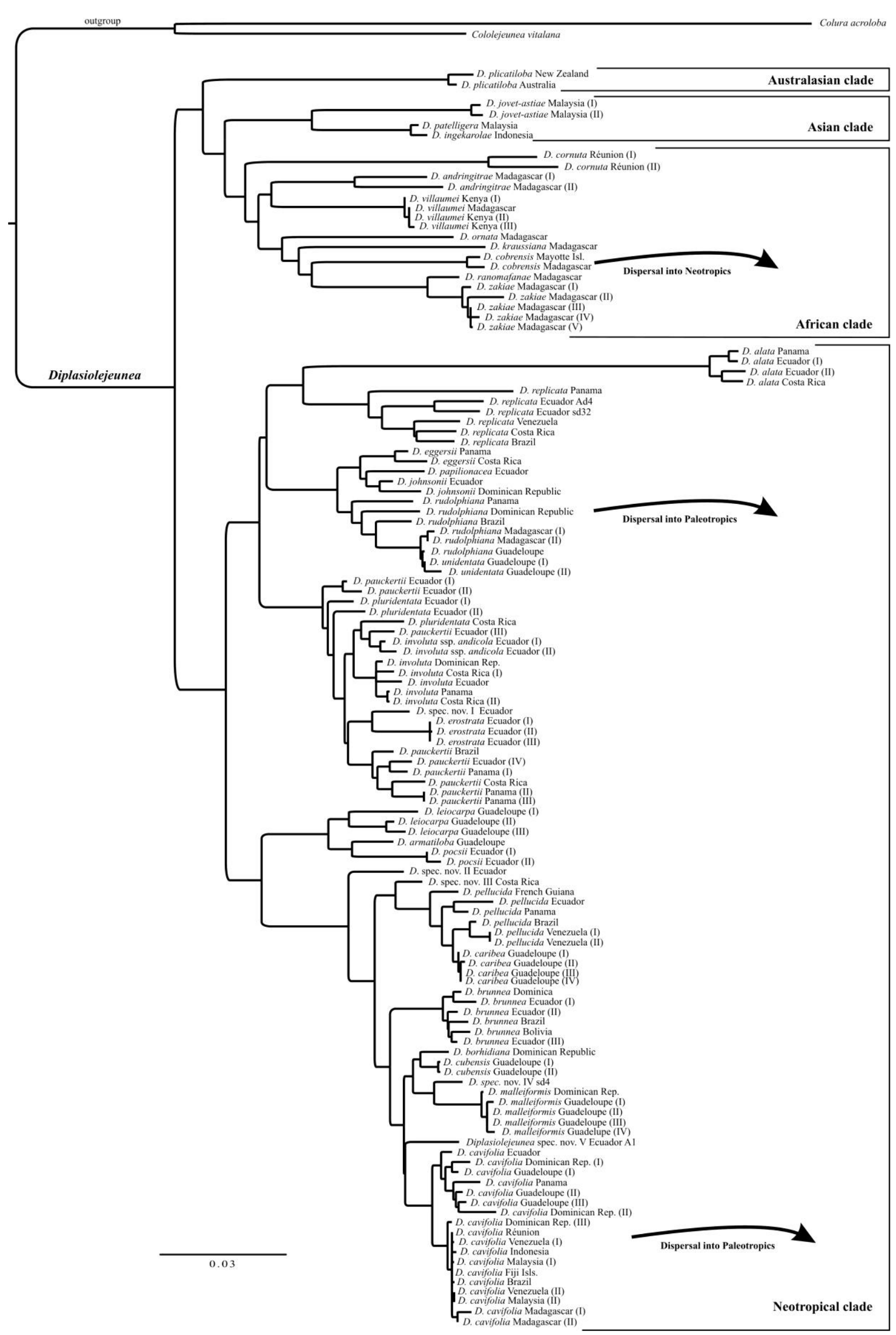

Fig. 2. A most likely phylogram resulting from maximum likelihood analysis of the combined comprehensive dataset. Bootstrap percentage values $>50$ are indicated at branches. A star indicates Bayesian support of 0.95-1.00. 


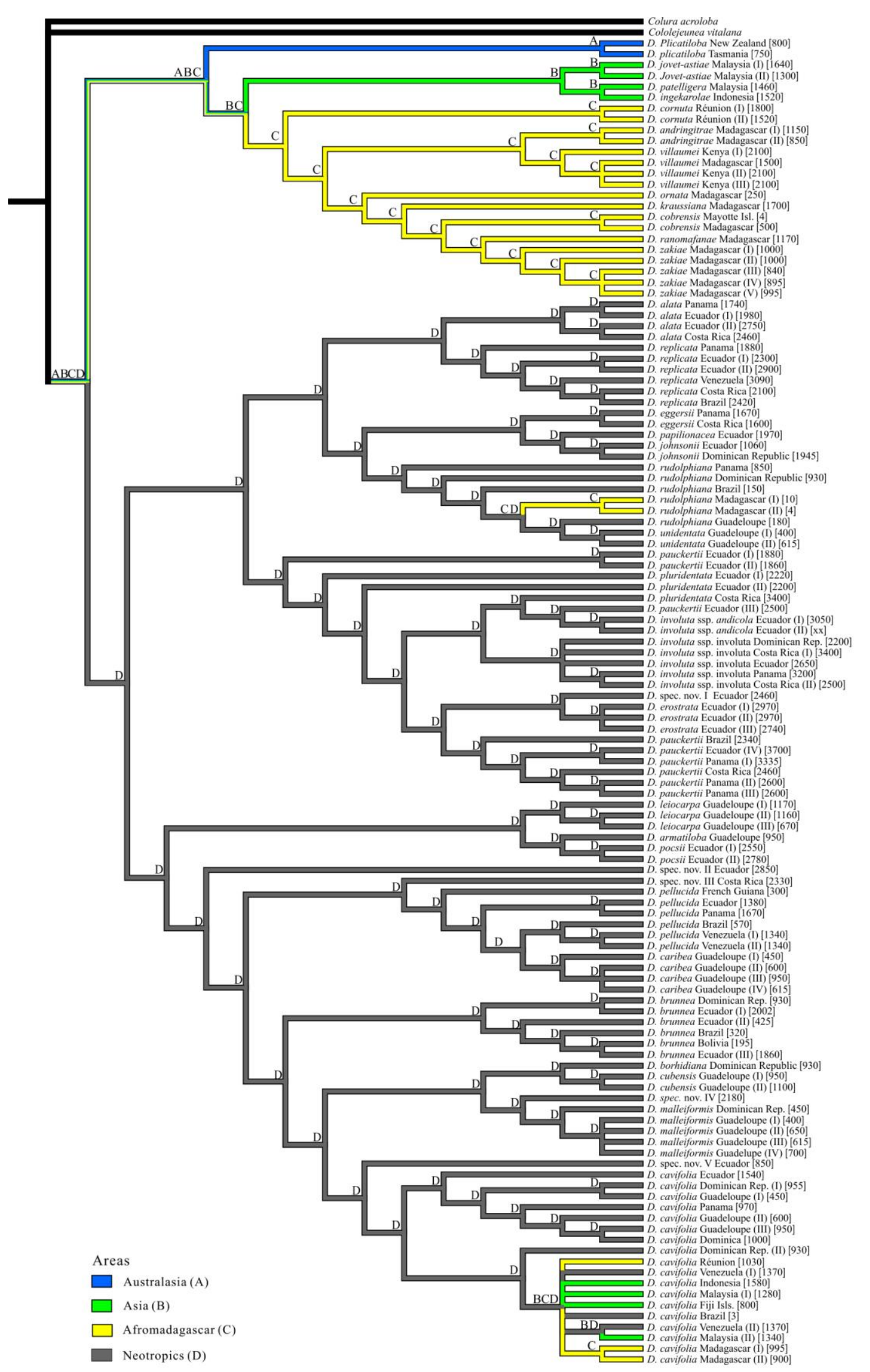

Fig. 3. Maximum likelihood topology of Diplasiolejeunea. Branch colors correspond to the most parsimonious reconstruction of distributions of Diplasiolejeunea and letters on the node show the reconstructed ancestral distribution. Altitudes of collections sites are indicated in square brackets.

82 


\section{Appendix 2}

\section{Molecular phylogeny of the leafy liverwort Lejeunea (Porellales): Evidence for a Neotropical origin, uneven distribution of sexual systems and insufficient taxonomy}

Jochen Heinrichs, Shanshan Dong, Alfons Schäfer-Verwimp, Tamás Pócs, Kathrin Feldberg, Aleksandra Czumaj, Alexander R. Schmidt, Joachim Reitner, Matt A.M. Renner, Jörn Hentschel, Michael Stech, Harald Schneider

Published in Plos l: 2013, 8(12): e82547. DOI: 10.1371/journal.pone.0082547 


\section{Abstract}

Background: Lejeunea is a largely epiphytic, subcosmopolitan liverwort genus with a complex taxonomic history. Species circumscriptions and their relationships are subject to controversy, biogeographic history and diversification through time are largely unknown.

Methodology and Results: We employed sequences of two chloroplast regions (trnL$t r n F, r b c L)$ and the nuclear ribosomal ITS region of 332 accessions to explore the phylogeny of the Harpalejeunea-Lejeunea-Microlejeunea complex. Lejeunea forms a well-supported clade that splits into two main lineages corresponding to $L$. subg. Lejeunea and L. subg. Crossotolejeunea. Neotropical accessions dominate early diverging lineages of both main clades of Lejeunea. This pattern suggests an origin in the Neotropics followed by several colonizations from the Neotropics into the Paleotropics and vice versa. Most Afromadagascan clades are related to Asian clades. Several temperate Lejeunea radiations were detected. Eighty two of the 91 investigated Lejeunea species could be identified to species level. Of these 82 species, 54 were represented by multiple accessions (25 para- or polyphyletic, 29 monophyletic). Twenty nine of the 36 investigated species of $L$. subg. Lejeunea were monoecious and 7 dioecious. Within L. subg. Crossotolejeunea, 15 of the 46 investigated species were monoecious and 31 dioecious. Some dioecious as well as some monoecious species have disjunct ranges.

Conclusions/Significance: We present the first global phylogeny of Lejeunea and the first example of a Neotropical origin of a Pantropical liverwort genus. Furthermore, we provide evidence for the Neotropics as a cradle of Lejeunea lineages and detect postcolonization radiations in Asia, Australasia, Afromadagascar and Europe. Dioecy/monoecy shifts are likely non-randomly distributed. The presented phylogeny points to the need of integrative taxonomical studies to clarify many Lejeunea binomials. Most importantly, it provides a framework for future studies on the diversification of this lineage in space and time, especially in the context of sexual systems in Lejeuneaceae.

Key words: biogeography, Harpalejeunea, Lejeuneaceae, Microlejeunea, reproductive biology, taxonomy 


\section{Introduction}

The taxonomic history of the leafy liverwort Lejeunea Lib. is best characterized as a story of controversial opinions on species delimitation and assumed relationships. Libert [1] described the genus based on only two species, Lejeunea calcarea Lib. [nowadays treated as Cololejeunea calcarea (Lib.) Schiffn.] and Lejeunea serpyllifolia Lib., the latter being a synonym of Lejeunea cavifolia (Ehrh.) Lindb. [2,3]. Soon after Libert's publication, the genus became widely recognized and numerous new species were described [4]. Until the end of the 19th century, the number of Lejeunea species exceeded one thousand [5] but early authors applied a wider genus concept than is accepted today. A good example in this regard is the treatment of Spruce [6] who classified Lejeunea in 39 subgenera. The majority of these subgenera was elevated to genus rank by Schiffner [7]. Subsequently, further new genera were introduced consisting of former Lejeunea species [e.g., 8-10]. As a consequence, Lejeunea species sensu Spruce [6] were placed in some 60 different genera [11].

Recent taxonomic and/or molecular phylogenetic studies of Lejeuneaceae led to a considerable reduction of genera [12-18]. This trend becomes particularly apparent in Lejeunea since more than a dozen generic names were recently lowered to synonyms of this genus $[15,18,19]$. Lejeunea is currently circumscribed by long-inserted leaves, divided or undivided underleaves, leaf lobules with an unreduced first tooth and a marginal hyaline papilla, small, segmented or homogeneous oil bodies, lack of ocelli, lejeuneoid innovations, unwinged female bracts and inflated perianths with 0-5 smooth or toothed wings $[17,20]$. Lejeunea is recognized for its morphological disparity. Diversification time estimates indicated an origin of Lejeunea in the early Cenozoic [2123]. The genus has its centre of diversity in the humid tropics where the species usually grow as epiphytes on stems, branches, twigs and leaves of a large number of cormophytes but also on rock [24]. Although the vast number of species occur exclusively in tropical climates, the genus is also well represented in temperate regions with a humid climate $[25,26]$.

According to recent estimates the species diversity of Lejeunea may exceed three hundred [27], however, the precise number of species is still unclear due to the limited 
availability of modern revisionary studies [13,28-30]. According to current knowledge, Lejeunea includes narrow endemics [29] as well as intercontinentally distributed species such as the subcosmopolitan Lejeunea flava (Sw.) Nees [31]. Intercontinental ranges have been accepted for many liverwort species due to an extensive morphological overlap of remote populations and the production of spores and propagules suitable for long-distance dispersal [32-34], although molecular phylogenetic studies incorporating multiple accessions of morphologically-typologically circumscribed liverwort species usually demonstrate a considerable genetic variation and a structure that is related to spatial ranges rather than to morphological disparities [35-40]. These studies also demonstrated the para- or polyphyly of many morphologically circumscribed liverwort species $[36,41,42]$.

The objective of this study is to reconstruct the first comprehensive phylogeny of Lejeunea using chloroplast and nuclear DNA markers. This phylogenetic framework is used to reconstruct the origin of the genus and infer evidence, which supports dispersal between the Neotropics and the Paleotropics [40], respectively the hypothesis of a tropical origin of the extant temperate species diversity [22,43]. In addition, we infer the evolution of reproductive systems with the focus on monoicy and dioicy in the evolution of Lejeunea. Finally, we test current morphological-typological species concepts by including multiple accessions and examine whether the recovered phylogenetic relationships correspond to/or conflict with morphologically circumscribed taxa.

\section{Results}

\section{Phylogeny - Reduced dataset}

The reduced dataset comprised one accession per ingroup species (specimens identified only to genus level excluded). Of a total of 2,351 character sites, 725 were parsimony informative, 248 unique to a single accession and 1,378 constant. The maximum parsimony (MP) analysis resulted in 4,578 most parsimonious trees with the features: length of 4,016 steps, consistency index of 0.38 , and retention index of 0.69 (Figure 1). Bayesian inference of phylogeny and maximum likelihood (ML) analyses recovered consensus trees respectively optimal trees that were highly similar in their 
topologies to each other as well as to the MP tree. The four representatives of Harpalejeunea (Spruce) Schiffn. formed a clade that was placed sister to a clade comprising two clades of which one included eight Microlejeunea Steph. species whereas the other one was composed by 82 Lejeunea species. The monophyly of Lejeunea achieves bootstrap percentage values (BPVs) of 99 or $100 \%$ and a Bayesian Posterior Probability (BPP) of 1.00 (Figure 1). The Lejeunea clade consisted of two main lineages corresponding to Lejeunea subg. Lejeunea (BPV MP $100 \%$, ML $100 \%$, BPP p $=1.00$ ) and $L$. subg. Crossotolejeunea Spruce (BPV MP $82 \%$ ML $97 \%$, BPP $p=1.00$ ). In past classification, the investigated Lejeunea species were alternatively placed in 32 different genera, with up to 6 different treatments per species (Figure 1). Lejeunea species previously treated as Taxilejeunea (Spruce) Schiffn. were diffusely distributed and nested in most Lejeunea clades. Elements of Crossotolejeunea (Spruce) Schiffn. were found in both main lineages of Lejeunea. Twenty nine of the 36 investigated representatives of Lejeunea subg. Lejeunea were monoicous (81\%) and 7 (19\%) dioicous (Figure 1). Within Lejeunea subg. Crossotolejeunea, 15 of the 46 investigated species were monoicous (33\%) and 31 dioicous (67\%). Ancestral character reconstruction recovered dioicy as the likely ancestral state of Lepidolejeunea R.M.Schust., Harpalejeunea, and Microlejeunea, whereas the ancestral state of Lejeunea was found to be equivocal in maximum parsimony reconstructions. In maximum likelihood reconstructions, dioicy was found to be ancestral with a probability of 0.75 versus a probability of 0.25 for monoicy. The ancestral state of $L$. subg. Lejeunea was either resolved as equivocal (50\% of most parsimonious trees) or monoicous ( $50 \%$ of most parsimonious trees). ML reconstructions recovered a probability of monoicy of 0.71 . Similarly, the ancestral state of subg. Crossotolejeunea was found to be equivocal in all most parsimonious trees but showed a probability of 0.77 to be dioicous (Table 1 ).

\section{Phylogeny - Large dataset}

The large dataset consisted of 2,351 character sites (909 parsimony informative, 1,212 constant). The MP analysis resulted in more than 350,000 equally parsimonious trees with a length of 6,427 steps, a consistency index of 0.30 and a retention index of 0.83 (not depicted). 
The ML phylogeny based on the large dataset is shown in Figure S1. A condensed version without species labeling is depicted in Figure 2. The Lejeunea clade was pruned and split in three parts, which are depicted in Figure 3, with BPPs and ML/MP BPVs indicated at branches. The phylogeny was consistent to the topology derived from the reduced dataset albeit without good ML BPV for Lejeunea subg. Crossotolejeunea (ML $\mathrm{BPV}=65 \%$ ). Out of the 82 Lejeunea species with reliable species identification, 54 were represented by multiple accessions. Twenty five of these 54 Lejeunea species were resolved as para- or polyphyletic, whereas 29 were monophyletic. Intercontinental ranges of several Lejeunea species were confirmed.

\section{Biogeography}

The most parsimonious reconstruction of ancestral areas of distribution based on the large dataset (Figures 2, 3 A-C) indicated a Neotropical origin of Lejeunea as well as of its subgenera Crossotolejeunea and Lejeunea. The S-Diva reconstruction generated from the reduced dataset suggested two scenarios. In scenario one both subgenera originated in the Neotropics, whereas in the other scenario two alternative solutions were found for L. subg. Crossotolejeunea (Figure 4). In the second scenario, L. subg. Crossotolejeunea originated in an area comprising the Neotropics but also Europe plus Macaronesia and North Africa. African and Asian accessions were found to be nested in derived lineages. Lejeunea subg. Crossotolejeunea comprised a species rich radiation in Afro-Madagascar, Africa, and Asia that likely originated from a single colonization of the Paleotropics from the Neotropics. Each four clades of Lejeunea were recovered with occurrences in Australasia or North America respectively, five clades with occurrences in Macaronesia and Atlantic Europe, and seven clades with occurrences in temperate/subtropical Asia (Figure 3). The subcosmopolitan L. flava complex nested in an African lineage. Accessions from Gough Island were resolved in Neotropical lineages; accessions from Easter Island in tropical Asian clades. The African-Neotropical $L$. trinitensis Lindenb. \& Gottsche nested in a Neotropical clade; the Neotropical $L$. adpressa Nees in a clade dominated by Asian accessions. North American accessions of L. lamacerina (Steph.) Schiffn. are placed sister to European/Macaronesian accessions. 


\section{Discussion}

\section{Supraspecific classification}

Recent molecular phylogenetic studies identified a monophylum with representatives of Harpalejeunea, Microlejeunea and Lejeunea [17]. Furthermore, a recent report showed that the putatively allied genus Bromeliophila R.M.Schust. [20] forms a sister relationship with Prionolejeunea (Spruce) Schiffn. rather than nesting in Lejeunea [44]. Morphologically, Lejeunea differs from the former two genera by a lack of ocelli [the sole representative of Lejeunea with ocelli, L. huctumalcensis Lindenb. \& Gottsche, belongs to another main lineage of Lejeuneaceae (Czumay et al., unpublished)]. The monophyly of Harpalejeunea, Microlejeunea and Lejeunea is confirmed in our study, with Microlejeunea placed sister to Lejeunea.

Lejeunea has been classified in some 50 subgenera of which 17 are still accepted as part of Lejeunea. These subgenera are usually defined by one or a few morphological character states, and their recognition and circumscription is subject to controversy. A good example is Lejeunea subg. Taxilejeunea which was alternatively treated as separate genus Taxilejeunea, and as such accepted by several recent authors $[9,12,45,46]$, although the morphology of both genera is largely overlapping [12]. This situation is reflected in our phylogeny, with Taxilejeunea elements in nearly all lineages of Lejeunea (Figure 1). The problematic circumscription of Lejeunea taxa is also reflected in the alternative placement of the 82 identified species of our study in 32 different genera of Lejeuneaceae (Figure 1), with one species in up to six genera (Lejeunea apiculata Sande Lac.). Lejeunea splits into two main clades with heterogeneous morphology. One includes the generitype L. serpyllifolia (= L. cavifolia) and the types of three further subgenera; the other clade comprises types of four different subgenera, the oldest available subgenus name being $L$. subg. Crossotolejeunea Spruce (type: L. boryana Mont.) (Figure 1). Lejeunea subg. Crossotolejeunea was proposed for monoicous species with decurved and acuminate leaf apices, and 5-keeled perianths with denticulate and fimbriate keels [6]. A few years later, Crossotolejeunea was raised to generic rank [7]. However, Crossotolejeunea was synonymized with Lejeunea because the diagnostic character combinations were found to be inconsistent among species considered to belong to Crossotolejeunea [13]. The 
polyphyly of Crossotolejeunea as circumscribed by Spruce [6] is confirmed in the presented study by recovering Crossotolejeunea representatives in both main clades of Lejeunea (Figure 1). However, the presence of the type species L. boryana in the second main clade allows the assignment of $L$. subg. Crossotolejeunea. Incongruence of morphology-based classifications and molecular phylogenies was reported for a rapidly increasing number of genera of liverworts such as Athalamia Falc. [47], Cololejeunea (Spruce) Schiffn. [48], Diplasiolejeunea (Spruce) Schiffn. [40], Frullania Raddi [49], Plagiochila (Dumort.) Dumort. [50], Porella L. [51], Radula Dumort. [52], Scapania (Dumort.) Dumort. [53], Syzygiella Spruce [54], and Telaranea Schiffn. [55]. Together, these studies clarified the phylogeny of these liverworts and provided the foundation to introduce new classifications using holophyly as the main criterion [40,52,56-58]. Unfortunately, many of these newly circumscribed taxa lack obvious morphological diagnostic characters hampering assignments of species to these clades using solely morphology.

In this study we propose to assign the two main Lejeunea clades to Lejeunea subg. Crossotolejeunea and Lejeunea subg. Lejeunea but hesitate to establish further supraspecific entities. In our opinion, it is premature to introduce a comprehensive classification of the two subgenera into sections since our Lejeunea sampling is still rather incomplete in the context of taxonomic sampling. In addition, further studies are required to explore the morphological features of species recovered in well supported clades. A good example in this regard is the morphological treatment of L. pulverulenta (Gottsche ex Steph.) M.E.Reiner [46]. In this study, L. pulverulenta was assumed to be aligned with L. controversa Gottsche and L. cerina (Lehm. \& Lindenb.) Gottsche et al. based on morphological similarities, e.g. the papillose leaf cells with trigones and intermediate cell wall thickenings. A sister relationship of $L$. pulverulenta and $L$. controversa ( $L$. subg. Crossotolejeunea) is confirmed (Figure 1 ) but L. cerina is found to be nested in Lejeunea subg. Lejeunea instead of $L$. subg. Crossotolejeunea.

The morphology of many Lejeunea species has not yet been exhaustively studied and our knowledge is often restricted to descriptions of the gross morphology of the gametophyte. Schuster $[9,31]$ repeatedly pointed to the taxonomical value of character states visible only in living plants, namely the oil bodies, and the sporophytes. Only 
recently it was shown that the rough surface of Lejeunea species is not necessarily caused by papillae but can also result from the production of surface waxes [59]. We need comprehensive morphological datasets of gametophytes and sporophytes besides expansion of molecular datasets to establish a hierarchical classification of Lejeunea into subgenera and sections. These data will also demonstrate whether clades share certain morphologies or can only be defined by DNA sequence evidence.

\section{Circumscription of species}

The present study addressed the reliability of current morphological-typological species concepts in Lejeunea by sampling multiple accessions of several currently accepted species. In the absence of studies on speciation processes and the maintenance of species borders in Lejeunea, we consider three criteria - diagnostic morphology, biogeographic consistency, and reciprocal monophyly - as the most reliable procedure to identify putative species [60]. Congruence between the phylogenies derived from either the nuclear or the chloroplast markers is interpreted as evidence for reproductive isolation. Hence we regard incongruence of morphologically circumscribed taxa with molecular phylogenies as evidence for the limitations of our current morphology-based classification. However, integration of molecular and exhaustive morphological data allows often but not always for a reconsideration of morphological features considered to be of diagnostic importance and result in modified species circumscriptions [e.g., 61-64]. These short-term solutions are practical and helpful despite the amount of efforts required. In addition, they may allow to recognize the extent of the failure of current taxonomic practice.

Multiple accessions of 29 Lejeunea species formed monophyletic lineages but 25 species proved to be para- or polyphyletic (Figure $3 \mathrm{~A}-\mathrm{C}$ ). The ratio of nearly $50 \%$ rejection of currently accepted species is remarkable and requires further using of more comprehensive datasets and analyses. These datasets may expand not only the number of accessions studied per species but also explore the genetic diversity by employing markers that will allow a more comprehensive study of the genotypic distinction such as ISSRs, AFLPs, and SNPs. Exhaustive studies with such marker-systems hold special promises for lineages with a low clade diversity such as the Lejeunea cavifolia $-L$. 
eckloniana Lindenb. - L. holtii Spruce-complex. The high number of non-monophyletic Lejeunea-species indicates that our current morphology-based classification does not adequately consider the possible presence of morphologically cryptic or semicryptic entities, and local endemism $[38,62,65]$. Some studies reported evidence for rather limited morphological variation among Lejeunea species and thus morphologically similar plants may be placed in different main clades of Lejeunea. A good example is the Lejeunea tumida Mitt. complex whose representatives are placed in both main clades of Lejeunea although they were earlier treated as a single species [30,42]. This observation is consistent with the results available for other genera of Lejeuneaceae, namely Marchesinia Gray [36], Ptychanthus Nees [66], Mastigolejeunea (Spruce) Schiffn. and Thysananthus Lindenb. [67]. All these studies suggest that we currently underestimate Lejeuneaceae species diversity. Examples supporting this notion are reported here with Lejeunea flava and $L$. laetevirens Nees \& Mont., which may in fact represent complexes including several independent entities. Lejeunea flava has been studied exhaustively using morphological evidence and several subspecies or segregates have been proposed $[10,31,68,69]$. However, we were not able to adopt these taxonomical concepts for our phylogeny (Figure $3 \mathrm{C}$ ) although we could recognize some morphological tendencies and found the morphologically well separated species $L$. acuta Mitt. and L. tuberculosa Steph. nested in the L. flava clade. The L. laetevirens complex is similarly problematic since our phylogeny indicates that several still unrecognized entities hide in L. laetevirens s.l.: A robust clade with Neotropical and Macaronesian accessions of $L$. laetevirens is placed sister to a Neotropical clade with $L$. laetevirens morphotypes as well as multiple accessions of L. multidentata M.E.Reiner \& Mustelier and L. ramulosa (Herzog) R.M.Schust. The latter two species differ from $L$. laetevirens by dentate or acute leaves. Lejeunea multidentata was aligned with $L$. boryana Mont. and $L$. controversa rather than with $L$. laetevirens based on shared dull appearance caused by strongly papillose cells [70,71], however, according to our phylogenies these species are not closely related. An extension of the sampling is necessary to revise the taxonomy of the $L$. laetevirens clade. The same holds true for the polyphyletic $L$. anisophylla Nees \& Mont. and several other problematic binomials. 


\section{Dispersal biogeography}

Liverworts produce spores and small propagules that are capable for distribution through air currents over larger distances [72,73]. However, population studies of liverworts generally show a spatial distribution of genetic diversity that does not correspond to a general panmixis hypothesis $[74,75]$. Thus, the current distribution of liverworts is not random and biogeographic studies frequently recover conserved biogeographic patterns that can be interpreted by considering the combination of processes such as occasional long distance dispersal, frequent dispersal over short distances, local extinction, and local diversification [76,77]. The reported distribution of Lejeunea suggests that this genus is not an exception and that conserved spatial patterns exist. Although the limited availability of lejeuneoid fossils prevents us from a detailed reconstruction of divergence times (the two Miocene fossils Lejeunea sp. [78] and Lejeunea palaeomexicana Grolle [79] cannot be assigned to any of our Lejeunea clades) an early Cenozoic origin of the genus can be assumed based on the existing estimates [21-23]. This time frame provides information about the position of the continents which is important in distinguishing between establishment via long-distance dispersal versus vicariance as the preferred explanation for the observed disjunct ranges. Dispersal over larger distances seems to occur only infrequently in Lejeunea, as is indicated by the clear geographical structure of disjunct species as well as multispecies clades. A good example is the L. lamacerina clade that splits into a North American and a European/Macaronesian lineage, without any evidence of recent geneflow. The unsatisfactory taxonomy of many other investigated clades hampers similar statements, however, the long branches in many morphologically circumscribed species and their para- or polyphyly provide evidence for local diversification/speciation. Evidence for lacking or restricted geneflow between distant liverwort populations has been demonstrated several times $[74,80]$ and can also be concluded for Lejeunea. Local diversification subsequent to successful long-distance dispersal seems to dominate the evolutionary history of Lejeunea. Accordingly, the majority of the investigated Lejeunea species has regional distribution ranges but about $23 \%$ of the identified species are more widespread and occur in at least two of our ten putative areas of endemism. Examples include the Neotropical-Macaronesian range of $L$. laetevirens, the Neotropical-Asian range of $L$. trinitensis Lindenb. \& Gottsche (Figure 3 B) and the 
African-Asian range of $L$. anisophylla (Figure $3 \mathrm{C}$ ).

\section{Neotropical origin}

The early diverging lineages of both main clades of Lejeunea occur predominantly in the Neotropics. Thus, our reconstructions revealed a Neotropical origin of Lejeunea with subsequent dispersal into other tropical as well as temperate regions. A Neotropical origin has been shown for several lineages of angiosperms, namely Burmanniaceae [81], Burseraceae [82], Gentianaceae [83] and Malpighiaceae [84]. It has also been discussed for the grammitid clades of polygrammoid ferns $[85,86]$ and the NeotropicalAfrican liverwort Bryopteris (Nees) Lindenb. [87] but has not yet been proposed for any subcosmopolitan liverwort genus based on molecular data. This is partly caused by the limited access to comprehensive phylogenies of species-rich liverwort genera $[40,49,51$ $54,76,77,88]$. The lejeuneoid genus Diplasiolejeunea shows a somewhat different pattern with a deep split into a Paleotropical and a Neotropical clade [40], but a few Pantropical species soften this otherwise strict separation by indicating occasional intercontinental dispersal events. In contrast to the pattern in Diplasiolejeunea both main clades of Lejeunea show a more even representation of putative regions of endemism, indicating that long distance dispersal is more frequent in Lejeunea than in Diplasiolejeunea as long as we assume similar ages for both genera.

Our topologies point to several dispersal events from the Neotropics into Africa ( $L$. trinitensis, L. phyllobola Nees \& Mont.). This pattern is not uncommon in leafy liverworts and has been recovered for Herbertus juniperoideus (Sw.) Grolle [77], Marchesinia brachiata (Sw.) Schiffn. [36], Plagiochila boryana Steph. [56] and the genus Bryopteris [87]. The subcosmopolitan L. flava complex appears to have originated in Africa and subsequently colonized large parts of the tropics and adjacent regions, with several dispersal events between the Old and the New World. This pattern of older spatial separations followed by young inter-continental dispersals was reported for a few plants such as the fern genus Nephrolepis Schott [89] and the pantropical liverwort Plagiochila sect. Vagae Lindenb. [56]. Our phylogenies support close relationships of African and Asian Lejeunea floras, however, the Neotropical L. adpressa is of Paleotropical, most likely Asian, origin (Figure $3 \mathrm{C}$ ). Lejeunea-accessions from the Polynesian Easter Island 
are likewise related to Asian clades whereas the Lejeunea accessions from Gough Island (Southern Atlantic Ocean) are nested in Neotropical lineages. A South American origin of Gough Island liverworts has already been demonstrated for the genus Herbertus [90]. The Macaronesian accessions of $L$. laetevirens are nested in a Neotropical clade, indicating dispersal from the Neotropics into Macaronesia. This pattern seems to be common in leafy liverworts and has also been reconstructed for species of Plagiochila [91] and Leptoscyphus Mitt. [92].

\section{The tropics as a cradle and museum}

Lejeunea has its centre of diversity in the humid lowlands and lower montane sites of the tropics; its diversity in temperate regions is considerably lower. This pattern is consistent with the widely recognized latitudinal biodiversity gradient [43,93-96]. Various hypotheses have been introduced to explain the origin of this gradient (see [43] for review) of which some involve the rather controversial concept of niche conservatism. So far, very little attention has been given to latitudinal biodiversity gradients in seed-free land plants, but is starting to be explored in ferns (see [97]) and here in the liverwort genus Lejeunea. In accordance with the general hypothesis of a latitudinal diversity gradient, Lejeunea includes only a few temperate lineages, which are in each case nested in tropical clades.

The pattern observed for Lejeunea appears to be consistent with the role of the tropics as a cradle and museum of diversity [98-100], and mirrors observations for the whole family Lejeuneaceae [22]. Liverwort families with a centre of diversity in the tropical highlands can show considerably different patterns and may have entered the tropics from temperate regions [76]. Interestingly, temperate species were not always found to possess a tropical sister species but evidence for several radiations in temperate regions were discovered, including two multi-species clades with occurrences in Australasia, one with occurrences in temperate Asia, and two with occurrences in Macaronesia and Atlantic Europe (Figs 3 A-C). The discovery of these clades provides opportunities to test some of the arguments concerning the origin of the latitudinal diversity gradient such as niche conservatism and different speciation rates [97,101]. The recovery of radiations in the temperate climate zones of Australasia resembles the 
recent report of a New Zealand radiation of grammitid ferns [102]. Grammitid ferns share with Lejeunea their origin in tropical regions and their preference to climates with high humidity. These examples may indicate the possibility of high speciation rates in temperate climates caused by ecological opportunities. The observed change in the climatic niche preferences is again consistent with reports in tree ferns growing in the wet temperate climates of Australasia [103].

\section{Sexual systems in a largely epiphytic genus}

About two third of liverworts are dioicous [104] whereupon the distribution of dioicous and monoicous species differs from genus to genus. The speciose genus Plagiochila is a prime example of a completely dioicous group whereas monoicous species dominate in Cololejeunea (Spruce) Schiffn., Riccia L. and Riccardia Gray [24,105]. The evolution of sexual systems has so far been studied for only two genera of liverworts using a phylogenetic framework: the largely epiphytic leafy liverworts Radula Dumort. and Diplasiolejeunea $[40,106]$. Only 16 of the ca. 200 Radula species are monoicous whereas monoicy and dioicy is more evenly distributed in Diplasiolejeunea. Single monoicous species of Radula were resolved in several otherwise dioicous clades, a similar supposedly random pattern was observed in Diplasiolejeunea. Monoicy in Radula was also not correlated with obligate epiphytism but occurred in facultative epiphytic lineages [106].

In Lejeunea we observed an uneven distribution of sexual systems (Figure 1). Lejeunea subg. Lejeunea is dominated by monoicous species whereas dioicous species dominate in L. subg. Crossotolejeunea. Similarly to the situation in Radula, some monoicous species clustered in clades dominated by dioicous species, in particular in $L$. subg. Crossotolejeunea. However, monoicous species are the most frequent in $L$. subg. Lejeunea and our character reconstruction (Table 1) recovered some indications for the transition from dioicy to monoicy in the early diversification of the genus. We also found evidence for a rather frequent change of the reproductive system during the history of the genus with a minimum number of character state changes: five times in $L$. subg. Lejeunea and nine times in L. subg. Crossotolejeunea.

Monoicous species are potentially capable to produce sporophytes through self- 
fertilization. On one hand this may allow a more frequent establishment of new populations via long distance dispersal, but on the other hand this may result in invariable genotypes, accumulation of genetic load, and limited adaptation to new environments [105]. However, dioicy is not necessarily a barrier to regular sporophyte development. Many Plagiochila species frequently produce sporophytes as do at least some dioicous species of Frullania and Porella $[50,105]$. Thus, future studies need to explore the accumulation of genetic load, effective population size, and the temporal stability of habitats as factors that shape the evolution of reproductive systems in Lejeunea.

According to existing data, both dioicous and monoicous Lejeunea species are able to form disjunct ranges. However, disjunctions over large distances might not necessarily be the result of spore dispersal but could also be caused by vegetative reproduction through propagules. Vegetative reproduction plays an important role in the range formation of liverworts and enhances the chances of establishing in a new environment, especially for dioicous species. A dioicous long-distance disperser is trapped in a very small area unless it is able to colonize its new environment through vegetative distribution. Accordingly the likelihood of the arrival of spores of the other sex clearly increases with range expansion through vegetative distribution. However, Lejeunea includes only few species that frequently produce propagules [107], despite wide species distribution ranges. A further aspect may be variation in the extinction risks caused by the different sexual systems but very little evidence exists to evaluate this factor.

Schuster [31] emphasizes the importance of monoicy for species colonizing unstable epiphytic habitats but many Lejeunea species are dioicous. This trend is even more evident in the sister genus Microlejeunea which is nearly completely dioicous [24], despite its general preference for epiphytic habitats. The same applies to Radula. Devos et al. [106] speculate that dioicous epiphytes often distribute vegetatively, not only through specialised propagules but also through unspecialized gametophyte fragments, and that they are often not strictly depending on epiphytic environments. Kraichak [108] reinforces this argument by demonstrating a correlation of reproduction through asexual propagules and an epiphyllous mode of life in Lejeuneaceae. 
Currently the importance of monoicy for an epiphytic mode of life and long distance dispersal is rather unclear since the available studies point to more complex interrelationships. Future studies should not only focus on an extension of the phylogenetic sampling and improvements of the underlying taxonomy but also on the ecological ranges of disjunct liverworts. Intercontinentally distributed Diplasiolejeunea species have broader ecological amplitudes compared to geographically more restricted species [40], allowing for the colonization of a larger number of environments and enhancing the chance of a permanent establishment. We also need comprehensive studies on the resistance of spores and vegetative propagules of liverworts against drought and frost and the ability of sporophyte production under suboptimal climatic conditions.

\section{Perspectives}

Lejeunea is a prime example to illustrate the current state of affairs in liverwort classification. After three centuries of morphology-based research a plethora of taxa have been proposed in this genus, of which only a small part has been included in modern revisions, reflecting the limited number of liverwort specialists dealing with these taxonomically difficult plants. Our molecular data add to growing evidence that not all biologically relevant entities can be detected using solely morphology, and that the acceptance of a considerable intraspecific morphological variation may lead to an underestimation of the actual number of biological species [109,110]. Thus, concepts considering cryptic and semi-cryptic species may provide more realistic estimates than the current practice. Based on our topology it is possible to identify species complexes that are not yet properly understood and that need to be studied using extended datasets. We urgently need molecular studies incorporating numerous accessions of morphologically circumscribed species from throughout their range. Only combined molecular-morphological studies will allow to understand range formation and to establish more natural species circumscriptions [111]. These studies will also facilitate estimates of the real number of biological species of liverworts. It is not unlikely that a portion of these species will not exhibit morphological disparities or can at best been identified using statistical methods and larger series of reference specimens [112]. In such a situation, reference sequences (= DNA barcodes) are the most promising 
approach to obtain reliable identifications of these plants [113]. However, the establishment of the DNA barcodes needs to go hand-in-hand with critical taxonomic revision of species-rich genera like Lejeunea. The reported phylogeny provides the framework enabling the design and management of these studies because the major task of taxonomic revisions can be separated in groups of species belonging to the same clade.

\section{Materials and Methods}

\section{Taxon sampling and outgroup selection}

Taxa studied, including GenBank accession numbers and voucher details, are listed in Table S1. Ingroup taxa were selected according to availability and to represent the morphological variation and geographical distribution of Lejeunea. Representatives of the sister genera Harpalejeunea and Microlejeunea [17] were included to test the Lejeunea genus concept. Multiple accessions of several species were used to explore intraspecific genetic variation. Representatives of Lepidolejeunea were selected as outgroup species based on the analyses of [14] and [17]. Altogether 332 accessions from the herbaria AK, DUKE, EGR, GOET, JE, L, or NSW were used for this study.

\section{DNA extraction, PCR amplification and sequencing}

Upper parts of a few gametophytes were isolated from herbarium specimens. Total genomic DNA was extracted using Invisorb Spin Plant Mini Kit (Invitek, Berlin, Germany) prior to amplification. Protocols for PCR were carried out as described in previous publications: $r b c L$ gene and $t r n L-F$ region from [114], and nrITS1-5.8S-ITS-2 region from [87]. Bidirectional sequences were generated using a MegaBACE 1000 automated sequencing machine using BigDye ${ }^{\circledR}$ Terminator v3.1 Cycle Sequencing Kit (Applied Biosystems, Foster City, CA, USA). Sequencing primers were those used for PCR. Newly generated sequences were assembled and edited using SeqAssem [115]. Seven hundred and nineteen sequences were newly generated for this study; 175 sequences were downloaded from Genbank.

\section{Phylogenetic analyses}

All sequences were aligned manually in Bioedit version 7.0.5.2 [116] resulting in a 
$r b c L$ alignment with 895 positions, trnL-F 441 and an nrlTS alignment with 1,015 putatively homologous sites. Ambiguous positions were excluded from all alignments and lacking data were coded as missing. Two datasets were compiled and analysed separately: dataset 1 (= large dataset) included all studied accessions, whereas dataset 2 (= reduced dataset) included only one accession per identified ingroup species. Accessions identified only to genus level were excluded from dataset 2. Phylogenetic trees based on the reduced dataset were used to visualize the current supraspecific classification of Lejeunea and to explore the evolution of monoicy/dioicy.

Maximum parsimony (MP) analyses were carried out with PAUP* version $4.0 b 10$ [117]. MP heuristic searches of the comprehensive and the reduced datasets were conducted with the following options implemented: heuristic search mode, 1,000 random-additionsequence replicates, tree bisection-reconnection (TBR) branch swapping, MULTrees option on, and collapse zero-length branches off. All characters were treated as equally weighted and unordered. Non-parametric bootstrapping values [118] were generated as heuristic searches with 1,000 replicates, each with ten random-addition replicates. The number of rearrangements was restricted to ten millions per replicate. Bootstrap percentage values (BPV) $\geq 70$ were regarded as good support [119]. Where more than one most parsimonious tree was found, trees were summarized as strict consensus tree(s). The three genomic regions and the combined chloroplast DNA dataset vs nrITS dataset were first analysed separately to check for topological incongruence. The consensus trees of the non-parametric bootstrap analyses were compared by eye to identify conflicting nodes supported by at least $70 \%$ [120]. The trees gave no evidence of incongruence. Accordingly, the datasets were combined.

The program jModeltest 0.1 .1 [121] was used to select a best-fit model of sequence evolution for the maximum likelihood (ML) analyses of the each genomic region, using the Akaike information criterion. The following models were chosen for the respective data divisions: (rbcL) TPM1 uf $+\mathrm{I}+\mathrm{G}$; (trnL-F) TVM+G and (nrITS) TIM3+G. A partitioned ML bootstrap analysis was conducted using the program Garli 2.0 [122]. The analysis was run until five million generations were completed without significant improvement (In $L$ increase of 0.01 ) to the topology. Node support was evaluated through 200 bootstrap replicates in which each repetition terminated after 100,000 generations were 
completed without topological improvements.

Bayesian inference was implemented in the program MrBayes 3.2 [123] allowing different models for each partition. Bayesian searches were carried out with four simultaneous Markov chains, ten million generations, and sampling every $1000^{\text {th }}$ generation. The first $25 \%$ of trees were discarded as burn-in. Bayesian posterior probability (BPP) confidence values were generated from trees saved after this initial burn-in. Values were regarded as significant when BPP $\geq 0.95$ [124].

\section{Ancestral areas of distribution}

Data on distribution ranges of the investigated taxa were obtained from the literature. Given the wide distribution ranges of some species, the putative distribution range of endemism was coded as covering ten possible areas: Neotropics, North America, Southern South America, Europe with North Atlantic Islands (e.g. Macaronesia) and North Africa (Africa north of the Sahara), Afro-Madagascar (sub-Saharan Africa, Madagascar, Mascarenes, Seychelles, and São Tomé), continental Asia (comprising temperate and subtropical regions), tropical Asia (including Melanesia and tropical Australia), temperate Australia and New Zealand, Tristan da Cunha Islands and Easter Island. Ancestral areas of distribution were reconstructed using two different approaches. The first approach was based on the large dataset and considers the presence of several unidentified species with unclear distribution ranges. To overcome this problem, the putative region of endemism (= the ten regions mentioned above, see also Fig. 2) of every accession was coded rather than the species range. Subsequently we reconstructed ancestral areas of distribution using MP criteria as implemented in Mesquite ver. 2.75 [125] based on the ML topology.

In the second approach we used dataset 2 including each one accession per identified species and a coding of the complete species range. Ancestral areas of distribution were reconstructed using S-DIVA [126] as implemented in RASP 2.0 based on 7,500 Bayesian trees from the reduced dataset.

\section{Evolution of reproductive systems}

The occurrence of dioicous/monoicous reproductive systems was scored by 
evaluating the information provided in the literature for each species included in dataset 2 [13,28,31,45,68,127-137]. In case both character states were indicated (L. hibernica Grolle, [131]), the species was scored as monoicous. These efforts resulted into a matrix of two character states without any polymorphic or unknown character states. To explore the evolution of this character, we used the results of the MP analyses of the reduced dataset. Maximum parsimony character reconstructions were carried out using Mesquite 2.75. The character states were plotted over all most parsimonious trees recovered in the MP analysis of the reduced dataset. Nodes absent from some of these trees were ignored. In addition, we carried out maximum likelihood analyses using the MK model [138] and the strict consensus tree obtained from the most parsimonious tree set.

\section{Acknowledgements}

We thank the curators and directors of the herbaria cited in the text for the loan of specimens and permission for destructive sampling.

\section{References}

1. Libert M (1820) Sur un genre nouveau d'Hépatiques, Lejeunia. Ann Gen Sci Phys 6: 372-374.

2. Bonner CEB, Miller HA (1960) Studies in Lejeuneaceae, I. The typification of Lejeunea. Bryologist 63: 217-225.

3. Grolle R (1971) Miscellanea hepaticologica 111-120. Trans Brit Bryol Soc 6: 258265.

4. Gottsche CM, Lindenberg JBG, Nees ab Esenbeck CG (1844-1847) Synopsis Hepaticarum. Hamburg: Meissner. 834 p.

5. Reiner-Drehwald ME (1999) Catalogue of the genus Lejeunea Lib. (Hepaticae) of Latin America. Bryophyt Biblioth 54: 1-101.

6. Spruce RM (1884) Hepaticae Amazonicae et Andinae. Tribus I: Jubuleae. Trans Proc Bot Soc Edinburgh 15: 1-308. 
7. Schiffner V (1893) Hepaticae. In: Engler A, Prantl K, editors. Die natürlichen Pflanzenfamilien 1. Engelmann: Leipzig. pp. 97-141.

8. Evans AW (1904) Hepaticae of Puerto Rico IV. Odontolejeunea, Cyclolejeunea and Prionolejeunea. Bull Torr Bot Club 31: 183-226.

9. Schuster RM (1994) Studies on Lejeuneaceae, I. Preliminary studies on new genera and subgenera of Lejeuneaceae. J Hattori Bot Lab 75: 211-235.

10. Reiner-Drehwald ME (2000) On Potamolejeunea and Neopotamolejeunea gen. nov. (Lejeuneaceae, Hepaticae). Nova Hedwigia 71: 447-464.

11. Gradstein SR, Reiner-Drehwald ME, Jost L (2004) The systematic position and distribution of Myriocolea irrorata (Lejeuneaceae), an endangered liverwort of the Ecuadorian Andes. J Hattori Bot Lab 95: 235-248.

12. Reiner-Drehwald ME (2005) On Lejeunea rotundifolia and Dicladolejeunea (Lejeuneaceae, Jungermanniopsida). Syst Bot 30: 687-692.

13. Reiner-Drehwald ME, Goda A (2000) Revision of the genus Crossotolejeunea (Lejeuneaceae, Hepaticae). J Hattori Bot Lab 89: 1-54.

14. Wilson R, Gradstein SR, Schneider H, Heinrichs J (2007) Unravelling the phylogeny of Lejeuneaceae (Jungermanniopsida): evidence for four main lineages. Molec Phylogen Evol 43: 270-282.

15. Heinrichs J, Dong S, Feldberg K, Schäfer-Verwimp A, Schmidt AR (2012) Sphaerolejeunea (Lejeuneaceae, Porellales) is a synonym of Lejeunea. Phytotaxa 69: 7-15.

16. Heinrichs J, Dong S, Yu Y, Schäfer-Verwimp A, Pócs T, et al. (2012) A 150 year old mystery solved: Transfer of the rheophytic liverwort Myriocolea irrorata to Colura. Phytotaxa 66: 55-64.

17. Dong S, Schäfer-Verwimp A, Pócs T, Feldberg K, Czumaj A, et al. (2013) Size doesn't matter - recircumscription of Microlejeunea (Lejeuneaceae, Porellales) 
based on molecular and morphological evidence. Phytotaxa 85: 41-55.

18. Ye W, Wei YM, Schäfer-Verwimp A, Zhu RL (2013) Phylogenetic position of Oryzolejeunea (Lejeuneaceae, Marchantiophyta): Evidence from molecular markers and morphology. J Syst Evol 51: 468-475.

19. Pócs T (2011) What is Cladolejeunea Zwickel? New or little known epiphyllous liverworts, XV. Acta Biol Plant Agr 1: 53-62.

20. Gradstein SR (2013) A classification of Lejeuneaceae based on molecular and morphological evidence. Phytotaxa 100: 6-20.

21. Heinrichs J, Hentschel J, Wilson R, Feldberg K, Schneider H (2007) Evolution of leafy liverworts (Jungermanniidae, Marchantiophyta): estimating divergence times from chloroplast DNA sequences using penalized likelihood with integrated fossil evidence. Taxon 56: 31-44.

22. Wilson R, Heinrichs J, Hentschel J, Gradstein SR, Schneider H (2007) Steady diversification of derived liverworts under Tertiary climatic fluctuations. Biol Lett 3: 566-569.

23. Cooper ED, Henwood MJ, Brown EA (2012) Are the liverworts really that old? Cretaceous origins and Cenozoic diversifications in Lepidoziaceae reflect a recurrent theme in liverwort evolution. Biol J Linn Soc 107: 425-441.

24. Gradstein SR, Churchill SP, Salazar-Allen N (2001) Guide to the bryophytes of tropical America. Mem New York Bot Gard 86: 1-577.

25. Glenny D (1998) A revised checklist of New Zealand liverworts and hornworts. Tuhinga 10: 119-149.

26. Grolle R, Long DG (2000) An annotated check-list of the Hepaticae and Anthocerotae of Europe and Macaronesia. J Bryol 22: 103-140.

27. Lee GE, Gradstein SR (2013) Distribution and habitat of the Malaysian species of Lejeunea (Marchantiophyta: Lejeuneaceae), with description of Lejeunea 
tamaspocsii sp. nov. Pol Bot J 58: 59-69.

28. Ilkiu-Borges AL (2005) A taxonomic revision of Echinocolea (Lejeuneaceae, Hepaticae). Nova Hedwigia 80: 45-71.

29. Renner MAM, Brown EA, Wardle GM (2009) Lejeunea pocsii R.M. Schust. is a heterotypic synonym of L. helmsiana (Steph.) Steph. (Lejeuneaceae, Marchantiophyta). Nova Hedwigia 89: 335-348.

30. Renner MAM, Brown EA, Wardle GM (2010) The Lejeunea tumida species group (Lejeuneaceae, Jungermanniopsida) in New Zealand. Austral Syst Bot 23: 443462.

31. Schuster RM (1980) The Hepaticae and Anthocerotae of North America. Volume 4. New York: Columbia University Press. 1344 p.

32. Herzog T (1926) Geographie der Moose. Jena: Fischer. 439 p.

33. Grolle R (1969) Großdisjunktionen in Artarealen lateinamerikanischer Lebermoose. In: Fittkau EJ, editor. Biogeography and Ecology in South America. The Hague: Junk. pp. 562-582.

34. Gradstein SR, Pócs T, Váňa J (1983) Disjunct Hepaticae in tropical America and Africa. Acta Bot Hung 29: 127-171.

35. Fuselier L, Davison PG, Clements M, Shaw B, Devos N, et al. (2009) Phylogeographic analyses reveal distinct lineages of Metzgeria furcata and $M$. conjugata (Metzgeriaceae) in Europe and North America. Biol J Linn Soc 98: 745 $-756$.

36. Heinrichs J, Klugmann F, Hentschel J, Schneider H (2009) DNA taxonomy, cryptic speciation and diversification of the Neotropical-African liverwort, Marchesinia brachiata (Lejeuneaceae, Porellales). Molec Phylogen Evol 53: 113-121.

37. Heinrichs J, Kreier H-P, Feldberg K, Schmidt AR, Zhu RL, et al. (2011) Formalizing morphologically cryptic biological entities: New insights from DNA 
taxonomy, hybridization, and biogeography in the leafy liverwort Porella platyphylla (Jungermanniopsida, Porellales). Amer J Bot 98: 1252-1262.

38. Ramaiya M, Johnston MG, Shaw B, Heinrichs J, Hentschel J, et al. (2010) Morphologically cryptic biological species within the liverwort, Frullania asagrayana. Amer J Bot 97: 1707-1718.

39. Laenen B, Désamoré A, Devos N, Shaw AJ, Gonzáles-Mancebo JM, et al. (2011) Macaronesia: a source of hidden genetic diversity for post-glacial recolonization of western Europe in the leafy liverwort Radula lindenbergiana. J Biogeogr 38: 631-639.

40. Dong SS, Schäfer-Verwimp A, Meinecke P, Feldberg K, Bombosch A, et al. (2012) Tramps, narrow endemics and morphologically cryptic species in the epiphyllous liverwort Diplasiolejeunea. Molec Phylogen Evol 65: 582-594.

41. Feldberg K, Groth H, Wilson R, Schäfer-Verwimp A, Heinrichs J (2004) Cryptic speciation in Herbertus (Herbertaceae, Jungermanniopsida). Range and morphology of Herbertus sendtneri inferred from nrITS sequences. PI Syst Evol 249: 247-261.

42. Renner MAM, Brown EA, Wardle GM (2011) The Lejeunea tumida species group is positively polyphyletic (Lejeuneaceae: Jungermanniopsida). Austral Syst Bot 24: 10-18.

43. Mittelbach GG, Schemske DW, Cornell HV, Allen AP, Brown JM, et al. (2007) Evolution and the latitudinal diversity gradient: speciation, extinction and biogeography. Ecol Letters 10: 315-331.

44. Heinrichs J, Czumaj A, Dong S, Scheben A, Schäfer-Verwimp A, et al. (2013) The Bromeliaceae tank dweller Bromeliophila (Lejeuneaceae, Porellales) is a member of the Cyclolejeunea-Prionolejeunea clade. PI Syst Evol: doi 10.1007/s00606013-0860-4.

45. Reiner-Drehwald ME (2000) Las Lejeuneaceae (Hepaticae) de Misiones, 
Argentina VI. Lejeunea y Taxilejeunea. Trop Bryol 19: 81-131.

46. Reiner-Drehwald ME (2005) Taxilejeunea pulverulenta (Lejeuneaceae, Jungermanniopsida), a poorly known species from the Neotropics, is transferred to Lejeunea. Cryptog Bryol 26: 59-65.

47. Rubasinghe SCK, Milne R, Forrest LL, Long DG (2011) Realignment of the genera of Cleveaceae (Marchantiopsida, Marchantiaceae). Bryologist 114: 116127.

48. Yu Y, Pócs T, Schäfer-Verwimp A, Heinrichs J, Zhu RL, Schneider H (2013) Evidence for rampant homoplasy in the phylogeny of the epiphyllous liverwort genus Cololejeunea (Lejeuneaceae). Syst Bot 38: 553-563.

49. Hentschel J, von Konrat MJ, Pócs T, Schäfer-Verwimp A, Shaw AJ, et al. (2009) Molecular insights into the phylogeny and subgeneric classification of Frullania Raddi (Frullaniaceae, Porellales). Molec Phylogen Evol 52: 142-156.

50. Heinrichs J (2002) A taxonomic revision of Plagiochila sect. Hylacoetes, sect. Adiantoideae and sect. Fuscoluteae in the Neotropics with a preliminary subdivision of Neotropical Plagiochilaceae into nine lineages. Bryophyt Biblioth 58: 1-184, Append. 1-5.

51. Hentschel J, Zhu R-L, Long DG, Davison PG, Schneider H, et al. (2007) A phylogeny of Porella (Porellaceae, Jungermanniopsida) based on nuclear and chloroplast DNA sequences. Molec Phylogen Evol 45: 693-705.

52. Devos N, Renner MAM, Gradstein SR, Shaw J, Vanderpoorten A (2011) Molecular data challenge traditional subgeneric divisions in the leafy liverwort Radula. Taxon 60: 1623-1632.

53. Heinrichs J, Bombosch A, Feldberg K, Kreier HP, Hentschel J, et al. (2012) A phylogeny of the northern temperate leafy liverwort genus Scapania (Scapaniaceae, Jungermanniales). Molec Phylogen Evol 62: 973-985.

54. Feldberg K, Váňa J, Long DG, Shaw AJ, Hentschel J, et al. (2010) A phylogeny of 
Adelanthaceae (Jungermanniales, Marchantiophyta) based on nuclear and chloroplast DNA markers, with comments on classification, cryptic speciation and biogeography. Molec Phylogen Evol 55: 293-304.

55. Cooper ED, Henwood MJ, Brown EA (2012) A molecular phylogeny of the Lepidozia generic complex supports re-circumscription of the Lepidozioideae. Molec Phylogen Evol 65: 10-22.

56. Heinrichs J, Lindner M, Gradstein SR, Groth H, Buchbender V, et al. (2005) Origin and subdivision of Plagiochila (Jungermanniidae: Plagiochilaceae) in tropical Africa based on evidence from nuclear and chloroplast DNA sequences and morphology. Taxon 54: 317-333.

57. Feldberg K, Váňa J, Hentschel J, Heinrichs J (2010) Currently accepted species and new combinations in Jamesonielloideae (Adelanthaceae, Jungermanniales). Cryptog Bryol 31: 141-146.

58. Váňa J, Hentschel J, Müller J, Heinrichs J (2012) Taxonomic novelties in Scapania. Phytokeys 10: 13-17.

59. Heinrichs J, Reiner-Drehwald ME (2012) Surface wax in Dinckleria, Lejeunea and Mytilopsis (Jungermanniidae). Cryptog Bryol 33: 81-86.

60. De Queiroz K (2007) Species concepts and species delimitation. Syst Biol 56: 879-886.

61. Szweykowski J, Buczkowska K, Odrzykoski IJ (2005) Conocephalum salebrosum, (Marchantiopsida, Conocephalaceae) - a new holarctic liverwort species. PI Syst Evol 253: 133-158.

62. Feldberg K, Váňa J, Schulze C, Bombosch A, Heinrichs J (2011) Morphologically similar but genetically distinct: on the differentiation of Syzygiella concreta and $S$. perfoliata (Adelanthaceae subfam. Jamesonielloideae). Bryologist 114: 686-695.

63. Forrest LL, Salazar Allen N, Gudiño JA, Korpelainen H, Long DG (2011) Molecular and morphological evidence for distinct species in Dumortiera 
(Dumortieraceae). Bryologist 114: 102-115.

64. Patiño J, Devos N, Vanderpoorten A, Schäfer-Verwimp A, Renner M (2013) The identity of Radula carringtonii Jack. J Bryol.: in press.

65. Kreier HP, Feldberg K, Mahr F, Bombosch A, Schmidt AR, et al. (2010). Phylogeny of the leafy liverwort Ptilidium: cryptic speciation and shared haplotypes between the Northern and Southern Hemispheres. Molec Phylogen Evol 57: 1260-1267.

66. Ahonen I, Sass-Gyarmati A, Pócs T (2005) Molecular, morphological and taxonomic evaluation of the Ptychanthus striatus (Lejeuneaceae, Marchantiophyta) complex. Acta Bot Hung 47: 225-246.

67. Sukkharak P, Gradstein SR, Stech M (2011) Phylogeny, taxon circumscriptions, and character evolution in the core Ptychanthoideae (Lejeuneaceae, Marchantiophyta). Taxon 60: 1607-1622.

68. Jones EW (1968) African Hepatics. XIX. The Lejeunea flava complex. Trans Brit Bryol Soc 5: 548-562.

69. Ah-Peng C, Bardat J, Ellis L (2005) Additions to the bryoflora of Réunion Island (France). Lindbergia 30: 43-45.

70. Reiner-Drehwald ME, Martinez KM (2004) On Lejeunea multidentata, a new species from Cuba (Jungermanniopsida: Lejeuneaceae). J Bryol 26: 103-106.

71. Reiner-Drehwald ME (2010a) On Lejeunea subgenus Nanolejeunea (Lejeuneaceae, Jungermanniopsida). Nova Hedwigia Beih 138: 117-128.

72. Zanten BO van, Gradstein SR (1988) Experimental dispersal geography of Neotropical liverworts. Nova Hedwigia Beih 90: 41-94.

73. Zanten BO van, Pócs T (1981) Distribution and dispersal of bryophytes. In: Fittkau EJ, editor. Advances in Bryology. Vaduz: Cramer. pp. 479-562.

74. Pohjamo M, Korpelainen H, Kalinauskaite N (2008) Restricted gene flow in the 
clonal hepatic Trichocolea tomentella in fragmented landscapes. Biol Conserv 141: 1204-1217.

75. Vanderpoorten A, Gradstein SR, Carine MA, Devos N (2010) The ghosts of Gondwana and Laurasia in modern liverwort distributions. Biol Rev 85: 471-487.

76. Heinrichs J, Lindner M, Groth H, Hentschel J, Feldberg K, et al. (2006) Goodbye or welcome Gondwana? Insights into the phylogenetic biogeography of the leafy liverwort Plagiochila with a description of Proskauera, gen. nov. (Plagiochilaceae, Jungermanniales). PI Syst Evol 258: 211-226.

77. Feldberg K, Hentschel J, Wilson R, Rycroft DS, Glenny D, et al. (2007). Phylogenetic biogeography of the leafy liverwort Herbertus (Jungermanniales, Herbertaceae) based on nuclear and chloroplast DNA sequence data: correlation between genetic variation and geographical distribution. J Biogeogr 34: 688-689.

78. Reiner-Drehwald ME, Schmidt AR, Heinrichs J (2012) The genus Lejeunea in Miocene amber from the Dominican Republic. Cryptog Bryol 33: 33-38.

79. Grolle R (1984) Lejeunea palaeomexicana n. sp., das erste Moos aus mexikanischem Bernstein. Stuttg Beitr Naturk, Ser B 108: 1-7.

80. Korpelainen H, von Crautlein M, Laaka-Lindberg S, Huttunen S (2011) Fine-scale spatial genetic structure of a liverwort (Barbilophozia attenuata) within a network of ant trails. Evol Ecol 25: 45-57.

81. Merckx V, Chatrou LW, Lemaire B, Sainge MN, Huysmans S, et al. (2008) Diversification of myco-heterotrophic angiosperms: Evidence from Burmanniaceae. BMC Evol Biol 8: 178.

82. Weeks A, Daly DC, Simpson BB (2005) The phylogenetic history and biogeography of the frankincense and myrrh family (Burseraceae) based on nuclear and chloroplast sequence data. Molec Phylogen Evol 35: 85-101.

83. Merckx VSFT, Kissling J, Hentrich H, Janssens SB, Mennes CB, et al. (2013) Phylogenetic relationships of the mycoheterotrophic genus Voyria and the 
implications for the biogeographic history of Gentianaceae. Amer J Bot 100: 712721.

84. Davis CC, Bell CD, Mathews S, Donoghue MJ (2002) Laurasian migration explains Gondwanan disjunctions: Evidence from Malpighiaceae. Proc Nat Acad Sci U S A 99: 6833-6837.

85. Schneider H, Kreier HP, Janssen T, Otto E, Muth H, et al. (2010) Key innovations versus key opportunities: identifying causes of rapid radiations in derived ferns. In: Glaubrecht M, editor, Evolution in Action. Berlin: Springer. pp. 61-75.

86. Rouhan G, Labiak PH, Randrianjohany E, Rakotondrainibe F (2012) Not so Neotropical after all: the grammitid fern genus Leucotrichum (Polypodiacae) is also paleotropical, as revealed by a new species from Madagascar. Syst Bot 37: 331-338.

87. Hartmann FA, Wilson R, Gradstein SR, Schneider H, Heinrichs J (2006) Testing hypotheses on species delimitations and disjunctions in the liverwort Bryopteris (Jungermanniopsida: Lejeuneaceae). Int J PI Sci 167: 1205-1214.

88. Schaumann F, Frey W, Pfeiffer T, Stech M (2005) Molecular circumscription, intrafamilial relationships and biogeography of the Gondwanan liverwort family Pallaviciniaceae. PI Syst Evol 252: 27-48.

89. Hennequin S, Hovenkamp P, Christenhusz MJM, Schneider H (2010) Phylogenetics and biogeography of Nephrolepis - a tale of old settlers and young tramps. Bot J Linn Soc 164: 113-127.

90. Heinrichs J, Feldberg K, Kreier H-P, Váňa J (2010) DNA-based identification of Herbertus species on Gough Island, South Atlantic Ocean. Cryptog Bryol 31: 6774.

91. Heinrichs J, Lindner M, Groth R, Renker C (2005) Distribution and synonymy of Plagiochila punctata (Taylor) Taylor, with hypotheses on the evolutionary history of Plagiochila sect. Arrectae (Plagiochilaceae, Hepaticae). PI Syst Evol 250: 105-117. 
92. Vanderpoorten A, Long DG (2006) Budding speciation and neotropical origin of the Azorean endemic liverwort, Leptoscyphus azoricus. Molec Phylogen Evol 40: 73-83.

93. Wiens JJ, Donoghue MJ (2004) Historical biogeography, ecology and species richness. Trends Ecol Evol 19: 639-644.

94. Ricklefs RE (2010) Evolutionary diversification, coevolution between populations and their antagonists, and the filling of niche space. Proc Nat Acad Sci U S A 107: 1265-1272.

95. Schemske DW, Mittelbach GG, Cornell HV, Sobel JM, Roy K (2010) Is there a latitudinal gradient in the importance of biotic interactions. Ann Rev Ecol Evol Syst 40: 245-269.

96. Romdal TS, Araujo MB, Rahbeck C (2013) Life on a tropical planet: niche conservatism and the global diversity gradient. Global Ecol Biogeogr 22: 344-350.

97. Schneider H, He LJ, Marquardt J, Wang L, Heinrichs J, et al. (2013) Exploring the origin of the latitudinal diversity gradient: contrasting the sister fern genera Phegopteris and Pseudophegopteris. J Syst Evol 51: 61-70.

98. Jablonski D, Roy K, Valentine JW (2006) Out of the tropics: evolutionary dynamics of the latitudinal diversity gradient. Science 314: 102-106.

99. Marshall CR (2006) Fossil record reveals tropics as cradle and museum. Science 313: $66-67$.

100. McKenna DD, Farell BD (2006) Tropical forests are both evolutionary cradles and museums of leaf beetle diversity. Proc Natl Acad Sci U S A 103: 10 947-10 951.

101. Moreau CS, Bell CD (2013) Testing the museum versus cradle tropical biological diversity hypothesis: phylogeny, diversification, and ancestral biogeographic range evolution of the ants. Evolution. doi: 10.111/evo.12105.

102. Perrie LR, Parris BS (2012) Chloroplast DNA sequences indicate the grammitid 
ferns (Polypodiacae) in New Zealand belong to a single clade, Notogrammitis gen. nov. New Zealand J Bot 50: 475-472.

103. Bystriakova N, Schneider H, Coomes D (2011) Evolution of the climatic niche in scaly tree ferns (Cyatheaceae, Polypodiopsida). Bot J Linn Soc 165: 1-19.

104. Vanderpoorten A, Goffinet B (2009) Introduction to Bryophytes. Cambridge: Cambridge University Press. 303 p.

105. Longton RE, Schuster RM (1983) Reproductive biology. In: Schuster RM, editor, New manual of bryology. Nichinan: Hattori Botanical Laboratory. pp. 386-462.

106. Devos N, Renner MAM, Gradstein SR, Shaw J, Laenen B, et al. (2011) Evolution of sexual systems, dispersal strategies and habitat selection in the liverwort genus Radula. New Phytologist 192: 225-236.

107. Reiner-Drehwald ME (2010) A taxonomic revision of Lejeunea deplanata (Lejeuneaceae, Marchantiophyta) from tropical America. Nova Hedwigia 91: 519532.

108. Kraichak E (2012) Asexual propagules as an adaptive trait for epiphylly in tropical leafy liverworts (Lejeuneaceae). Amer J Bot 99: 1436-1444.

109. Heinrichs J, Hentschel J, Bombosch A, Fiebig A, Reise J, et al. (2010) One species or at least eight? Delimitation and distribution of Frullania tamarisci (L.) Dumort. (Jungermanniopsida, Porellales) inferred from nuclear and chloroplast DNA markers. Molec Phylogen Evol 56: 1105-1114.

110. Hutsemekers V, Vieira CC, Ros RM, Huttunen S, Vanderpoorten A (2012) Morphology informed by phylogeny reveals unexpected patterns of species differentiation in the aquatic moss Rhynchostegium riparioides s.l. Molec Phylogen Evol 62: 748-755.

111. Heinrichs J, Hentschel J, Feldberg K, Bombosch A, Schneider H (2009) Phylogenetic biogeography and taxonomy of disjunctly distributed bryophytes. J Syst Evol 47: 497-508. 
112. Renner MAM, Brown EA, Wardle GM (2013) Averaging v. outlier removal. Decrypting variance among cryptic Lejeunea species (Lejeuneaceae: Jungermanniopsida) using geometric morphometrics. Austral Syst Bot 26: 13-30.

113. Hollingworth PM, Forrest LL, Spouge JL, Hajibabaei M, Ratnasingham S, et al. (2009) A DNA barcode for land plants. Proc Nat Acad Sci U S A 31: 12794-12797.

114. Gradstein SR, Wilson R, Ilkiu-Borges AL, Heinrichs J (2006) Phylogenetic relationships and neotenic evolution of Metzgeriopsis (Lejeuneaceae) based on chloroplast DNA sequences and morphology. Bot J Linn Soc 151: 293-308.

115. Hepperle D (2004) SeqAssem@. A sequence analysis tool, contig assembler and trace data visualization tool for molecular sequences. Win32-Version. Distributed by the author via: http://www.sequentix.de.

116. Hall TA (1999) BIOEDIT: a user-friendly biological sequence alignment editor and analysis program for Windows 95/98/NT. Nucl Acids Symp Ser 41: 95-98.

117. Swofford DL (2000) PAUP*, phylogenetic analyses using parsimony ( ${ }^{*}$ and other methods), version 4.01b10. Sunderland, Sinauer Associates.

118. Felsenstein J (1985) Confidence limits on phylogenies: an approach using the bootstrap. Evolution 39: 783-791.

119. Hillis DM, Bull JJ (1993) An empirical test of bootstrapping as a method for assessing the confidence in phylogenetic analysis. Syst Biol 42: 182-192.

120. Mason-Gamer RJ, Kellogg EA (1996) Testing for phylogenetic conflict among molecular data sets in the tribe Triticeae (Gramineae). Syst Biol 45: 524-545.

121. Posada D (2008) jModelTest: Phylogenetic model averaging. Molec Biol Evol 25: 1253-1256.

122. Zwickl DJ (2006) Genetic algorithm approaches for the phylogenetic analysis of large biological sequence datasets under the maximum likelihood criterion. GARLI version 2.0 available online at https://code.google.com/p/garli/. 
123. Huelsenbeck JP, Ronquist F (2001) MRBAYES: Bayesian inference of phylogenetic trees. Bioinformatics 17: 754-755.

124. Larget B, Simon DL (1999) Markov chain Monte Carlo algorithms for the Bayesian analysis of phylogenetic trees. Molec Biol Evol 16: 750-759.

125. Maddison DR, Maddison WP (2004) Mesquite, version 2.75 Tucson, Arizona. Available at http://mesquiteproject.org.

126. Yu Y, Harris AJ, He XJ (2010) S-DIVA (statistical dispersal-vicariance analysis): a tool for inferring biogeographic histories. Molec Phylogen Evol 56: 848-850.

127. Stephani F (1898-1925) Species Hepaticarum 1-6. Geneva: Georg \& $C^{i e} .4354$ p.

128. Grolle R (1966) Lebermoose aus Neuguinea. 3. Stenolejeunea. J Hattori Bot Lab 29: 75-78.

129. Mizutani M (1971) Lejeunea from the Himalayan region. J Hattori Bot Lab 34: 445-457.

130. Reiner-Drehwald ME (1995) La familia Lejeuneaceae (Hepaticae) en Misiones, Argentina: estudio taxonómico-floristico. PhD thesis. 237 p.

131. Paton JA (1999) The liverwort flora of the British Isles. Colchester: Harley Books. $626 \mathrm{p}$.

132. Zhu R-L, Grolle R (2003) Taxonomy and distribution of Lejeunea exilis (Lejeuneaceae, Hepaticae). Ann Bot Fennici 40: 101-106.

133. Wigginton MJ, ed. (2004) E. W. Jones's liverwort and hornwort flora of West Africa. Scripta Bot Belg 30: 1-443.

134. Reiner-Drehwald ME, Schäfer-Verwimp A (2008) Lejeunea oligoclada and L. rionegrensis (Lejeuneaceae) in tropical America: new data on morphology and geographical distribution. Nova Hedwigia 87: 175-184.

135. Reiner-Drehwald ME, Schäfer-Verwimp A (2008) On Inflatolejeunea, Lejeunea 
species with eplicate perianths and Lejeunea talamancensis sp. nov. from Costa Rica (Lejeuneaceae). Nova Hedwigia 87: 387-420.

136. Gradstein SR, Ilkiu-Borges AL (2009) Guide to the plants of central French Guiana. Part 4. Liverworts and hornworts. Mem New York Bot Gard 76: 1-140.

137. Renner MAM (2013) Lejeunea subelobata and Lejeunea drummondii (Jungermanniopsida) in Australasia. Polish Bot J 58: 193-203.

138. Lewis PO (2001) A likelihood approach to estimating phylogeny from discrete morphological character data. Syst Biol 50: 913-925. 
Table 1. Ancestral character reconstruction of dioecious/monoecious reproductive systems. The reconstruction is based on the reduced dataset using Maximum Parsimony (MP) and Maximum Likelihood (ML).

\begin{tabular}{|c|c|c|c|c|}
\hline & MP Dioecy & MP Monoecy & $\begin{array}{l}\text { ML } \\
\text { Dioecy }\end{array}$ & $\begin{array}{l}\text { ML } \\
\text { Monoecy }\end{array}$ \\
\hline Lepidolejeunea & yes & No & 0.93 & 0.07 \\
\hline Harpalejeunea & yes & No & 0.98 & 0.02 \\
\hline Microlejeunea & yes & No & 0.93 & 0.07 \\
\hline Lejeunea & equivocal & equivocal & 0.75 & 0.75 \\
\hline L. subg. Lejeunea & $\begin{array}{l}\text { equivocal } \\
(50 \%) \\
\text { no }(50 \%)\end{array}$ & $\begin{array}{l}\text { equivocal } \\
(50 \%) \\
\text { yes (50\%) }\end{array}$ & 0.29 & 0.71 \\
\hline L. subg. Crossotolejeunea & equivocal & equivocal & 0.77 & 0.23 \\
\hline clade L. lamacerina-L. grossitexta & no & yes & 0.01 & 0.99 \\
\hline clade L. hibernica-L. oracola & no & yes & 0.29 & 0.71 \\
\hline clade L. pallescens- L. topoensis & no & yes & 0.24 & 0.76 \\
\hline clade $L$. catinulifera- $L$. oracola & yes & No & 0.75 & 0.25 \\
\hline clade L. amaniensis-L. oracola & no & yes & 0.10 & 0.90 \\
\hline clade $L$. asperrima- $L$. controversa & equivocal & equivocal & 0.40 & 0.60 \\
\hline clade $L$. trinitensis- $L$. adpressa & yes & No & 0.92 & 0.08 \\
\hline clade L. trinitensis-L. ruthei & yes & No & 0.96 & 0.04 \\
\hline clade L.capensis-L. adpressa & yes & No & 0.97 & 0.03 \\
\hline
\end{tabular}


Table S1. Taxa used in the present study. Information about the origin of the studied material, vouchers, as well as GenBank accession numbers is included. New sequences in bold face.

\begin{tabular}{|c|c|c|c|c|c|}
\hline \multirow{2}{*}{ Taxon } & \multirow{2}{*}{ Origin } & \multirow{2}{*}{ Collector } & \multicolumn{3}{|c|}{ GenBank Accession No. } \\
\hline & & & rbcL & $\operatorname{trnL-F}$ & nrlTS \\
\hline $\begin{array}{l}\text { Harpalejeunea. } \\
\text { grandis Grolle \& } \\
\text { M.E.Reiner }\end{array}$ & Colombia & Cleef 6450 (GOET) & KC313144 & KC313184 & KC313106 \\
\hline $\begin{array}{l}\text { H. grandistipula } \\
\text { R.M.Schust. }\end{array}$ & Ecuador & $\begin{array}{l}\text { Schäfer-Verwimp et } \\
\text { al. 24163/B (GOET) }\end{array}$ & KC313145 & KC313185 & KC313107 \\
\hline $\begin{array}{l}\text { H. marginalis } \\
\text { (Hook.f. \& Taylor) } \\
\text { Steph. }\end{array}$ & Chile & $\begin{array}{l}\text { Schäfer-Verwimp \& } \\
\text { Verwimp } 8082 \\
\text { (GOET) }\end{array}$ & KC313147 & KC313187 & KC313109 \\
\hline $\begin{array}{l}\text { H. molleri (Steph.) } \\
\text { Grolle }\end{array}$ & Azores & $\begin{array}{l}\text { Schäfer-Verwimp \& } \\
\text { Verwimp } 29334 \\
\text { (GOET) }\end{array}$ & KC313148 & KC313188 & KC313110 \\
\hline $\begin{array}{l}\text { Lejeunea acuta } \\
\text { Mitt. }\end{array}$ & Comoros & $\begin{array}{l}\text { Pócs et al. 9276/CX } \\
\text { (EGR) }\end{array}$ & KF556383 & KF556133 & KF556601 \\
\hline L. acuta & Kenya & $\begin{array}{l}\text { Chuah-Petiot Mb } 22 \\
\text { (JE) }\end{array}$ & KF556384 & KF556134 & KF555917 \\
\hline L. adpressa Nees & Dominican Rep. (I) & $\begin{array}{l}\text { Schäfer-Verwimp \& } \\
\text { Verwimp 26931/B } \\
\text { (GOET) }\end{array}$ & KF556386 & KF556136 & KF555919 \\
\hline L. adpressa & Dominican Rep. (II) & $\begin{array}{l}\text { Schäfer-Verwimp \& } \\
\text { Verwimp 27215/F } \\
\text { (GOET) }\end{array}$ & KF556387 & KF556137 & KF555920 \\
\hline L. adpressa & Dominican Rep. (III) & $\begin{array}{l}\text { Pócs \& Pócs 03156/F } \\
\text { (EGR) }\end{array}$ & KF556385 & KF556135 & KF555918 \\
\hline L. alata Gottsche & Malaysia & $\begin{array}{l}\text { Schäfer-Verwimp \& } \\
\text { Verwimp } 18912 \\
\text { (GOET) }\end{array}$ & -- & KF556140 & KF555922 \\
\hline $\begin{array}{l}\text { L. amaniensis } \\
\text { E.W.Jones }\end{array}$ & Ethiopia & Hylander 4589 (EGR) & KF556393 & KF556144 & KF555925 \\
\hline L. amaniensis & Kenya (I) & $\begin{array}{l}\text { Malombe } \\
5012 / \text { cau.x2 (EGR) }\end{array}$ & KF556390 & KF556141 & KF555923 \\
\hline L. amaniensis & Kenya (II) & $\begin{array}{l}\text { Malombe \& Chituyi } \\
\text { 5006/Si.1aS5 (EGR) }\end{array}$ & KF556392 & KF556143 & KF556603 \\
\hline L. amaniensis & Kenya (III) & $\begin{array}{l}\text { Malombe \& Soita } \\
\text { 5008/K.1cS5 (EGR) }\end{array}$ & KF556391 & KF556142 & KF555924 \\
\hline $\begin{array}{l}\text { L. anisophylla } \\
\text { Nees \& Mont. }\end{array}$ & China & $\begin{array}{l}\text { Koponen et al. } 56008 \\
(H)\end{array}$ & AY125943 & AY144484 & AY125348 \\
\hline L. anisophylla & Fiji Isls. & $\begin{array}{l}\text { Pócs \& Pócs 03307/O } \\
\text { (EGR) }\end{array}$ & KF556397 & KF556149 & KF555929 \\
\hline L. anisophylla & Indonesia & $\begin{array}{l}\text { Schäfer-Verwimp \& } \\
\text { Verwimp } 21131 \\
\text { (GOET) }\end{array}$ & KF556398 & KF556150 & KF555930 \\
\hline L. anisophylla & Japan & $\begin{array}{l}\text { Yamaguchi } 24461 \\
\text { (GOET) }\end{array}$ & KF556400 & KF556152 & KF555931 \\
\hline
\end{tabular}




\begin{tabular}{|c|c|c|c|c|c|}
\hline L. anisophylla & Kingdom of Tonga & $\begin{array}{l}\text { Schäfer } 18341 \\
\text { (GOET) }\end{array}$ & KF556394 & KF556145 & KF555926 \\
\hline L. anisophylla & Equatorial Guinea & Müller B312/B (EGR) & KF556399 & KF556151 & KF556605 \\
\hline L. anisophylla & $\begin{array}{l}\text { São Tomé and } \\
\text { Príncipe (I) }\end{array}$ & $\begin{array}{l}\text { Shevock \& Daniel } \\
34368 \text { (EGR) }\end{array}$ & KF556401 & KF556153 & KF556606 \\
\hline L. anisophylla & $\begin{array}{l}\text { São Tomé and } \\
\text { Príncipe (II) }\end{array}$ & $\begin{array}{l}\text { Pócs \& Pócs } 34749 \\
\text { (EGR) }\end{array}$ & KF556395 & KF556146 & KF555927 \\
\hline L. anisophylla & Vietnam (I) & Pócs 02103/V (EGR) & KF556396 & KF556148 & KF556604 \\
\hline L. anisophylla & Vietnam (II) & Pócs 02105/J (EGR) & KF556529 & KF556303 & KF556629 \\
\hline L. anisophylla & Vietnam (III) & Pócs 02103/C (EGR) & & KF556147 & KF555928 \\
\hline $\begin{array}{l}\text { L. apiculata Sande } \\
\text { Lac. }\end{array}$ & Indonesia & $\begin{array}{l}\text { Schäfer-Verwimp \& } \\
\text { Verwimp } 20985 \\
\text { (GOET) }\end{array}$ & ---------- & KF556154 & KF555932 \\
\hline L. aquatica Horik. & Japan & Higuchi 1021 (JE) & ----- & KF556155 & KF555933 \\
\hline $\begin{array}{l}\text { L. asperrima } \\
\text { Spruce }\end{array}$ & Panama & $\begin{array}{l}\text { Schäfer-Verwimp \& } \\
\text { Verwimp } 30817 \\
\text { (GOET) }\end{array}$ & KF556402 & KF556157 & KF555935 \\
\hline $\begin{array}{l}\text { L. asperula } \\
\text { (Steph.) Mizut. }\end{array}$ & Papua New Guinea & Streimann 40815 (JE) & --------- & KF556156 & KF555934 \\
\hline $\begin{array}{l}\text { L. bermudiana } \\
\text { (A.Evans) } \\
\text { R.M.Schust. }\end{array}$ & USA & Shaw 14939 (DUKE) & KF556403 & KF556158 & KF555936 \\
\hline L. boryana Mont. & Ecuador & $\begin{array}{l}\text { Schäfer-Verwimp \& } \\
\text { Nebel } 33218 \text { (GOET) }\end{array}$ & KF556404 & --------- & KF555937 \\
\hline L. boryana & French Guiana (I) & $\begin{array}{l}\text { Hartmann et al. 04- } \\
054 \text { (GOET) }\end{array}$ & ------- & KF556160 & ------- \\
\hline L. boryana & French Guiana (II) & $\begin{array}{l}\text { Holz FG 00-0103 } \\
\text { (GOET) }\end{array}$ & KF556405 & KF556159 & KF555938 \\
\hline $\begin{array}{l}\text { L. cancellata Nees } \\
\& \text { Mont. }\end{array}$ & Costa Rica (I) & $\begin{array}{l}\text { Schäfer-Verwimp \& } \\
\text { Holz SV/H-0507/C } \\
\text { (GOET) }\end{array}$ & KF556409 & KF556164 & KF555942 \\
\hline L. cancellata & Costa Rica (II) & $\begin{array}{l}\text { Schäfer-Verwimp \& } \\
\text { Holz SV/H-0374/A } \\
\text { (GOET) } \\
\text { GÖhäfor-Verwimn \& }\end{array}$ & KF556410 & KF556165 & KF556607 \\
\hline L. cancellata & Dominican Rep. & $\begin{array}{l}\text { Schäfer-Verwimp \& } \\
\text { Verwimp } 27005 \\
\text { (GOET) } \\
\text { Schäfer-Verwimp \& }\end{array}$ & KF556411 & KF556166 & KF556608 \\
\hline L. cancellata & Panama & $\begin{array}{l}\text { Verwimp } 30850 \\
\text { (GOET) }\end{array}$ & KF556408 & KF556163 & KF555941 \\
\hline $\begin{array}{l}\text { L. capensis } \\
\text { Gottsche }\end{array}$ & Brazil & $\begin{array}{l}\text { Schäfer-Verwimp \& } \\
\text { Verwimp } 15057 \\
\text { (GOET) }\end{array}$ & -.--- & KF556167 & KF555943 \\
\hline $\begin{array}{l}\text { L. catinulifera } \\
\text { Spruce }\end{array}$ & Ecuador & $\begin{array}{l}\text { Gradstein \& Mandl } \\
10141 \text { (GOET) }\end{array}$ & DQ983688 & DQ987411 & DQ987307 \\
\hline L. catinulifera & Ecuador & $\begin{array}{l}\text { Wilson et al. 04-01 } \\
\text { (GOET) }\end{array}$ & DQ983687 & DQ987432 & DQ987328 \\
\hline
\end{tabular}




\begin{tabular}{|c|c|c|c|c|c|}
\hline L. catinulifera & Ecuador & $\begin{array}{l}\text { Schäfer-Verwimp et } \\
\text { al. 24259/A (GOET) }\end{array}$ & KF556413 & ---------- & KF555945 \\
\hline L. catinulifera & Ecuador & $\begin{array}{l}\text { Schäfer-Verwimp et } \\
\text { al. } 24188 \text { (GOET) }\end{array}$ & KF556412 & KF556168 & KF555944 \\
\hline L. catinulifera & Ecuador & $\begin{array}{l}\text { Schäfer-Verwimp et } \\
\text { al. } 24248 \text { (GOET) }\end{array}$ & KF556414 & KF556169 & KF555946 \\
\hline $\begin{array}{l}\text { L. cavifolia (Ehrh.) } \\
\text { Lindb. }\end{array}$ & Belgium & $\begin{array}{l}\text { Heinrichs et al. } 3816 \\
\text { (GOET) }\end{array}$ & KF556419 & KF556174 & KF555950 \\
\hline L. cavifolia & Finland & Ahonen s.n. $(H)$ & AY125945 & AY144486 & AY125347 \\
\hline L. cavifolia & France & $\begin{array}{l}\text { Schäfer-Verwimp \& } \\
\text { Verwimp } 27247 \\
\text { (GOET) }\end{array}$ & KF556421 & KF556176 & KF555952 \\
\hline L. cavifolia & Georgia & $\begin{array}{l}\text { Hentschel Bryo } 04382 \\
\text { (JE) }\end{array}$ & KF556418 & KF556173 & KF555949 \\
\hline L. cavifolia & Germany (I) & $\begin{array}{l}\text { Heinrichs } 3695 \\
\text { (GOET) }\end{array}$ & AY548102 & DQ238581 & DQ987259 \\
\hline L. cavifolia & Germany (II) & $\begin{array}{l}\text { Schäfer-Verwimp \& } \\
\text { Verwimp } 28787 \\
\text { (GOET) }\end{array}$ & KF556420 & KF556175 & KF555951 \\
\hline L. cavifolia & Germany (III) & $\begin{array}{l}\text { Schäfer-Verwimp \& } \\
\text { Verwimp } 28806 \\
\text { (GOET) }\end{array}$ & KF556415 & KF556170 & KF555947 \\
\hline L. cavifolia & Greece (I) & Düll 1./10.5.2004 (JE) & KF556417 & KF556172 & KF555948 \\
\hline L. cavifolia & Greece (II) & $\begin{array}{l}\text { Schäfer-Verwimp \& } \\
\text { Verwimp } 15888 \\
\text { (GOET) }\end{array}$ & KF556416 & KF556171 & ---------- \\
\hline $\begin{array}{l}\text { L. cerina (Lehm. \& } \\
\text { Lindenb.) } \\
\text { Gottsche, Lindenb. } \\
\text { \& Nees }\end{array}$ & Costa Rica & $\begin{array}{l}\text { Schäfer-Verwimp \& } \\
\text { Holz SV/H-0471 } \\
\text { (GOET) }\end{array}$ & KF556425 & KF556180 & KF555955 \\
\hline L. cerina & Dominican Rep. & $\begin{array}{l}\text { Schäfer-Verwimp \& } \\
\text { Verwimp } 26978 \\
\text { (GOET) }\end{array}$ & -------- & KF556182 & KF555957 \\
\hline L. cerina & Ecuador (I) & $\begin{array}{l}\text { Schäfer-Verwimp \& } \\
\text { Nebel } 32122 \text { (GOET) }\end{array}$ & KF556423 & KF556178 & KF555954 \\
\hline L. cerina & Ecuador (II) & $\begin{array}{l}\text { Wilson et al 04-02 } \\
\text { (GOET) }\end{array}$ & DQ983686 & DQ987433 & DQ987329 \\
\hline L. cerina & Ecuador (III) & $\begin{array}{l}\text { Wilson et al 04-13 } \\
\text { (GOET) }\end{array}$ & DQ983689 & DQ987441 & DQ987339 \\
\hline L. cerina & Ecuador (IV) & $\begin{array}{l}\text { Schäfer-Verwimp \& } \\
\text { Nebel } 31942 \text { (GOET) }\end{array}$ & KF556422 & KF556177 & KF555953 \\
\hline L. cerina & Ecuador (V) & $\begin{array}{l}\text { Nöske \& Holz } 165 \\
\text { (GOET) }\end{array}$ & KF556424 & KF556179 & KF556609 \\
\hline L. cerina & Guadeloupe & $\begin{array}{l}\text { Schäfer-Verwimp \& } \\
\text { Verwimp } 22473 \\
\text { (GOET) }\end{array}$ & KF556426 & KF556181 & KF555956 \\
\hline L. cocoes Mitt. & Indonesia & $\begin{array}{l}\text { Schäfer-Verwimp \& } \\
\text { Verwimp } 21050 \\
\text { (GOET) }\end{array}$ & KF556430 & KF556186 & KF555961 \\
\hline
\end{tabular}




\begin{tabular}{|c|c|c|c|c|c|}
\hline L. cocoes & Solomon Isls. & Seaward 108088 (JE) & ---------- & KF556187 & KF555962 \\
\hline $\begin{array}{l}\text { L. colensoana } \\
\text { (Steph.) } \\
\text { M.A.M.Renner }\end{array}$ & New Zealand (I) & Renner 300101 (AK) & --- & JF308572 & JF308543 \\
\hline L. colensoana & New Zealand (II) & Renner 300127a (AK) & ---------- & JF308576 & JF308547 \\
\hline L. colensoana & New Zealand (III) & Renner 300044 (AK) & ---------- & JF308565 & JF308536 \\
\hline L. colensoana & New Zealand (IV) & Renner 300130 (AK) & - & JF308577 & JF308548 \\
\hline L. colensoana & New Zealand (V) & Renner 300028 (AK) & ---------- & JF308562 & JF308533 \\
\hline L. colensoana & New Zealand (VI) & Renner 300140 (AK) & - & JF308578 & JF308549 \\
\hline L. colensoana & New Zealand (VII) & Renner 300104 (AK) & --------- & JF308573 & JF308544 \\
\hline L. colensoana & New Zealand (VIII) & Renner 300103 (AK) & 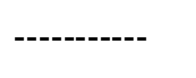 & JF308574 & JF308545 \\
\hline L. colensoana & New Zealand (IX) & Renner 300127 (AK) & ---------- & JF308575 & JF308546 \\
\hline L. colensoana & New Zealand $(X)$ & Renner 300039 (AK) & ---------- & JF308564 & JF308535 \\
\hline L. colensoana & New Zealand (XI) & Renner 300030 (AK) & ---------- & JF308563 & JF308534 \\
\hline $\begin{array}{l}\text { L. controversa } \\
\text { Gottsche }\end{array}$ & Bolivia & Gradstein 7189 (JE) & ----------- & KF556190 & KF556610 \\
\hline L. controversa & Brazil & Vital 8794 (GOET) & KF556431 & KF556188 & KF555963 \\
\hline L. controversa & French Guiana (I) & $\begin{array}{l}\text { Hartmann et al. 04- } \\
033 \text { (GOET) }\end{array}$ & KF556432 & KF556189 & KF555964 \\
\hline L. controversa & French Guiana (II) & $\begin{array}{l}\text { Hartmann et al. 04- } \\
092 \text { (GOET) }\end{array}$ & KF556434 & KF556192 & KF555965 \\
\hline L. controversa & Guadeloupe & $\begin{array}{l}\text { Schäfer-Verwimp \& } \\
\text { Verwimp } 22196 \\
\text { (GOET) }\end{array}$ & KF556433 & KF556191 & ------ \\
\hline $\begin{array}{l}\text { L. cristulata } \\
\text { (Steph.) } \\
\text { M.E.Reiner \& } \\
\text { Goda }\end{array}$ & Brazil & Giancotti 17 (JE) & ----------- & KF556193 & KF555966 \\
\hline $\begin{array}{l}\text { L. cuculliflora } \\
\text { (Steph.) Mizut. }\end{array}$ & Fiji Isls. (I) & $\begin{array}{l}\text { Pócs \& Pócs 03286/L } \\
\text { (EGR) }\end{array}$ & ----------- & KF556359 & KF556110 \\
\hline L. cuculliflora & Fiji Isls. (II) & $\begin{array}{l}\text { Pócs \& Pócs 03286/D } \\
\text { (EGR) }\end{array}$ & KF556435 & KF556194 & KF556611 \\
\hline L. cuculliflora & Fiji Isls. (III) & $\begin{array}{l}\text { Pócs \& Pócs } \\
\text { 03274/BL (EGR) }\end{array}$ & KF556577 & KF556358 & KF556109 \\
\hline L. curviloba Steph. & Bhutan & Long 10611 (JE) & ---------- & KF556195 & KF555967 \\
\hline L. cf. curviloba & Indonesia & $\begin{array}{l}\text { Gradstein } 10300 \\
\text { (GOET) }\end{array}$ & KF556427 & KF556183 & KF555958 \\
\hline
\end{tabular}




\begin{tabular}{|c|c|c|c|c|c|}
\hline $\begin{array}{l}\text { L. debilis (Lehm. \& } \\
\text { Lindenb.) Nees \& } \\
\text { Mont. }\end{array}$ & Costa Rica (I) & $\begin{array}{l}\text { Dauphin } 1793 \\
\text { (GOET) }\end{array}$ & KF556436 & KF556196 & KF555968 \\
\hline L. debilis & Costa Rica (II) & Biasi et al. 21 (GOET) & KF556438 & KF556198 & KF555970 \\
\hline L. debilis & $\begin{array}{l}\text { Costa Rica (III), La } \\
\text { Gamba }\end{array}$ & Schluder 7 (GOET) & KF556437 & KF556197 & KF555969 \\
\hline L. deplanata Nees & $\begin{array}{l}\text { Dominican Rep., } \\
\text { San José de Ocoa }\end{array}$ & $\begin{array}{l}\text { Schäfer-Verwimp \& } \\
\text { Verwimp } 26636 \\
\text { (GOET) }\end{array}$ & KF556442 & KF556202 & KF555974 \\
\hline L. deplanata & $\begin{array}{l}\text { Ecuador (I), } \\
\text { Imbabura }\end{array}$ & $\begin{array}{l}\text { Schäfer-Verwimp et } \\
\text { al. } 24260 / A \text { (GOET) }\end{array}$ & KF556440 & KF556200 & KF555972 \\
\hline L. deplanata & $\begin{array}{l}\text { Ecuador (II), } \\
\text { Pichincha }\end{array}$ & $\begin{array}{l}\text { Schäfer-Verwimp et } \\
\text { al. 24252/A (GOET) }\end{array}$ & KF556441 & KF556201 & KF555973 \\
\hline L. deplanata & $\begin{array}{l}\text { Ecuador (III), } \\
\text { Pichincha }\end{array}$ & $\begin{array}{l}\text { Schäfer-Verwimp et } \\
\text { al. 24502/C (GOET) }\end{array}$ & KF556439 & KF556199 & KF555971 \\
\hline $\begin{array}{l}\text { L. discreta } \\
\text { Lindenb. }\end{array}$ & Australia & $\begin{array}{l}\text { Thiers \& Halling } 2219 \\
\text { (L) }\end{array}$ & KF556444 & KF556206 & KF555977 \\
\hline L. discreta & China & Zhu 89038 (JE) & ------- & KF556204 & KF555976 \\
\hline L. discreta & Fiji Isls. & $\begin{array}{l}\text { Pócs \& Pócs } \\
\text { 03289/CA (EGR) }\end{array}$ & KF556443 & KF556203 & KF555975 \\
\hline L. discreta & Indonesia & $\begin{array}{l}\text { Gradstein } 12032 \\
\text { (GOET) }\end{array}$ & ----------- & KF556205 & ---------- \\
\hline $\begin{array}{l}\text { L. drehwaldii } \\
\text { Heinrichs \& Schäf.- } \\
\text { Verw. }\end{array}$ & Peru & Drehwald 4384 (JE) & KF556445 & KF556207 & KF555978 \\
\hline $\begin{array}{l}\text { L. drummondii } \\
\text { Taylor }\end{array}$ & Australia (I) & Streimann 16698 (JE) & --- & ------- & KF555979 \\
\hline L. drummondii & Australia (II) & Pamt 38AL (JE) & ----------- & KF556208 & KF555980 \\
\hline L. drummondii & Australia (III) & Jarman 91/4 (JE) & ---------- & KF556209 & KF555981 \\
\hline L. drummondii & Australia (IV) & $\begin{array}{l}\text { Renner } 872058 \\
\text { (NSW) }\end{array}$ & ----------- & JF308584 & JF308555 \\
\hline $\begin{array}{l}\text { L. eckloniana } \\
\text { Lindenb. }\end{array}$ & Azores & $\begin{array}{l}\text { Schäfer-Verwimp \& } \\
\text { Verwimp } 29528 \\
\text { (GOET) }\end{array}$ & KF556448 & KF556212 & KF555984 \\
\hline L. eckloniana & La Palma & $\begin{array}{l}\text { Schäfer- Verwimp } \\
24788 \text { (GOET) }\end{array}$ & DQ983690 & DQ987457 & DQ987357 \\
\hline L. eckloniana & Madeira (I) & Stech 04-271 (L) & KF556446 & KF556210 & KF555982 \\
\hline L. eckloniana & Madeira (I) & Stech 04-433 (L) & KF556447 & KF556211 & KF555983 \\
\hline $\begin{array}{l}\text { L. epiphylla } \\
\text { Colenso }\end{array}$ & New Zealand & Renner 300056 (AK) & ----------- & JF308568 & JF308539 \\
\hline $\begin{array}{l}\text { L. exilis (Reinw., } \\
\text { Blume \& Nees) } \\
\text { Grolle }\end{array}$ & Australia & $\begin{array}{l}\text { Renner } 872056 \\
\text { (NSW) }\end{array}$ & ----------- & JF308583 & JF308554 \\
\hline L. exilis & Indonesia (I) & $\begin{array}{l}\text { Schäfer-Verwimp \& } \\
\text { Verwimp } 25231 \\
\text { (GOET) }\end{array}$ & KF556449 & KF556213 & KF555985 \\
\hline
\end{tabular}




\begin{tabular}{|c|c|c|c|c|c|}
\hline L. exilis & Indonesia (II) & $\begin{array}{l}\text { Schäfer-Verwimp \& } \\
\text { Verwimp } 24853 \\
\text { (GOET) }\end{array}$ & KF556451 & KF556215 & KF555987 \\
\hline L. exilis & Indonesia (III) & $\begin{array}{l}\text { Schäfer-Verwimp \& } \\
\text { Verwimp 21080/B } \\
\text { (GOET) }\end{array}$ & KF556450 & KF556214 & KF555986 \\
\hline L. exilis & Malaysia & $\begin{array}{l}\text { Gradstein } 10336 \\
\text { (GOET) }\end{array}$ & DQ983691 & DQ987472 & ---------- \\
\hline L. flava (Sw.) Nees & Brazil (I) & Gradstein (GOET) & KF556480 & KF556244 & KF556010 \\
\hline L. flava & Brazil (II) & $\begin{array}{l}\text { Gradstein s.n. } \\
\text { (GOET) }\end{array}$ & DQ983692 & DQ987413 & DQ987309 \\
\hline L. flava & La Palma & $\begin{array}{l}\text { Schäfer-Verwimp \& } \\
\text { Verwimp } 24780 \\
\text { (GOET) }\end{array}$ & DQ983693 & ---------- & DQ987363 \\
\hline L. flava & Tenerife & $\begin{array}{l}\text { Drehwald \& Drehwald } \\
4121 \text { (GOET) }\end{array}$ & KF556478 & KF556242 & KF556008 \\
\hline L. flava & Dominican Rep. (I) & $\begin{array}{l}\text { Schäfer-Verwimp \& } \\
\text { Verwimp 26855/B } \\
\text { (GOET) }\end{array}$ & KF556479 & KF556243 & KF556009 \\
\hline L. flava & Dominican Rep. (II) & $\begin{array}{l}\text { Schäfer-Verwimp \& } \\
\text { Verwimp } 27043 \\
\text { (GOET) }\end{array}$ & KF556452 & KF556216 & KF556612 \\
\hline L. flava & Easter Island & $\begin{array}{l}\text { Ireland \& Bellolio } \\
30111 \text { (JE) }\end{array}$ & KF556469 & KF556234 & KF556001 \\
\hline L. flava & Ecuador (I) & $\begin{array}{l}\text { Schäfer-Verwimp \& } \\
\text { Preussing 23435/A } \\
\text { (GOET) }\end{array}$ & KF556454 & KF556218 & KF556613 \\
\hline L. flava & Ecuador (II) & $\begin{array}{l}\text { Schäfer-Verwimp \& } \\
\text { Preussing 23203/B } \\
\text { (GOET) }\end{array}$ & KF556471 & KF556236 & KF556003 \\
\hline L. flava & Fiji Isls. & $\begin{array}{l}\text { Pócs \& Pócs 03269/F } \\
\text { (EGR) }\end{array}$ & KF556463 & KF556227 & KF555996 \\
\hline L. flava & Gough Island & $\begin{array}{l}\text { Gremmen 2005-0794 } \\
\text { (EGR) }\end{array}$ & KF556484 & KF556248 & KF556013 \\
\hline L. flava & Guadeloupe & $\begin{array}{l}\text { Schäfer-Verwimp \& } \\
\text { Verwimp } 22495 \\
\text { (GOET) }\end{array}$ & KF556473 & KF556237 & KF556005 \\
\hline L. flava & India & $\begin{array}{l}\text { Schäfer-Verwimp \& } \\
\text { Verwimp } 28396 \\
\text { (GOET) }\end{array}$ & KF556462 & KF556226 & KF555995 \\
\hline L. flava & Indonesia (I) & $\begin{array}{l}\text { Schäfer-Verwimp \& } \\
\text { Verwimp 25243/C } \\
\text { (GOET) }\end{array}$ & KF556453 & KF556217 & KF555988 \\
\hline L. flava & Indonesia (II) & $\begin{array}{l}\text { Schäfer-Verwimp \& } \\
\text { Verwimp 21078/A } \\
\text { (GOET) }\end{array}$ & KF556466 & KF556230 & KF555998 \\
\hline L. flava & Indonesia (III) & $\begin{array}{l}\text { Gradstein } 12037 \\
\text { (GOET) }\end{array}$ & KF556481 & KF556245 & KF556619 \\
\hline L. flava & Indonesia (IV) & $\begin{array}{l}\text { Schäfer-Verwimp \& } \\
\text { Verwimp } 24907 \\
\text { (GOET) }\end{array}$ & KF556467 & KF556231 & KF556616 \\
\hline
\end{tabular}




\begin{tabular}{|c|c|c|c|c|c|}
\hline L. flava & Indonesia (V) & $\begin{array}{l}\text { Schäfer-Verwimp \& } \\
\text { Verwimp } 24825 \\
\text { (GOET) }\end{array}$ & KF556460 & KF556224 & KF555993 \\
\hline L. flava & Indonesia (VI) & $\begin{array}{l}\text { Schäfer-Verwimp \& } \\
\text { Verwimp 24806/B } \\
\text { (GOET) }\end{array}$ & KF556455 & KF556219 & KF555989 \\
\hline L. flava & Indonesia (VII) & $\begin{array}{l}\text { Schäfer-Verwimp \& } \\
\text { Verwimp 24901/A } \\
\text { (GOET) }\end{array}$ & ----------- & KF556232 & KF555999 \\
\hline L. flava & Kenya (I) & $\begin{array}{l}\text { Chuah et al. } 03017 / \mathrm{H} \\
\text { (EGR) }\end{array}$ & KF556566 & KF556347 & -------- \\
\hline L. flava & Kenya (II) & $\begin{array}{l}\text { Pócs \& Pócs } \\
\text { 04011/AY (EGR) }\end{array}$ & ---------- & KF556250 & KF556620 \\
\hline L. flava & Kenya (III) & $\begin{array}{l}\text { Pócs \& Pócs } \\
\text { 04013/M (EGR) }\end{array}$ & KF556586 & KF556368 & KF556120 \\
\hline L. flava & Kenya (VI) & $\begin{array}{l}\text { Pócs \& Pócs 04026/X } \\
\text { (EGR) }\end{array}$ & KF556587 & KF556369 & KF556121 \\
\hline L. flava & Kenya (V) & $\begin{array}{l}\text { Pócs \& Pócs 04026/X } \\
\text { (EGR) }\end{array}$ & KF556588 & KF556370 & KF556635 \\
\hline L. flava & Madeira (I) & $\begin{array}{l}\text { Drehwald } 3722 \\
\text { (GOET) }\end{array}$ & KF556472 & ----------- & KF556004 \\
\hline L. flava & Madeira (II) & Stech 09-425 (L) & KF556474 & KF556238 & KF556006 \\
\hline L. flava & Malaysia (I) & $\begin{array}{l}\text { Schäfer-Verwimp \& } \\
\text { Verwimp 18541/C } \\
\text { (GOET) }\end{array}$ & KF556459 & KF556223 & KF555992 \\
\hline L. flava & Malaysia (II) & $\begin{array}{l}\text { Schäfer-Verwimp \& } \\
\text { Verwimp 18861/B } \\
\text { (GOET) }\end{array}$ & KF556458 & KF556222 & KF556614 \\
\hline L. flava & Malaysia (III) & $\begin{array}{l}\text { Schäfer-Verwimp \& } \\
\text { Verwimp 18528/A } \\
\text { (GOET) }\end{array}$ & KF556461 & KF556225 & KF555994 \\
\hline L. flava & Nepal & Long 17308 (JE) & KF556470 & KF556235 & KF556002 \\
\hline L. flava & $\begin{array}{l}\text { New Zealand, North } \\
\text { Island }\end{array}$ & $\begin{array}{l}\text { Braggins } 90 / 30 \\
(\text { GOET) }\end{array}$ & KF556475 & KF556239 & KF556617 \\
\hline L. flava & Panama & $\begin{array}{l}\text { Schäfer-Verwimp \& } \\
\text { Verwimp } 30873 \\
\text { (GOET) }\end{array}$ & KF556482 & KF556246 & KF556011 \\
\hline L. flava & Réunion (I) & $\begin{array}{l}\text { Gradstein } 12013 \\
\text { (GOET) }\end{array}$ & KF556465 & KF556229 & KF555997 \\
\hline L. flava & Réunion (II) & Pócs 9501/J (EGR) & KF556487 & KF556252 & KF556016 \\
\hline L. flava & Réunion (III) & Pócs 08068/Z (EGR) & KF556486 & KF556251 & KF556015 \\
\hline L. flava & $\begin{array}{l}\text { São Tomé and } \\
\text { Príncipe }\end{array}$ & $\begin{array}{l}\text { Shevock } 34217 \\
\text { (EGR) }\end{array}$ & KF556464 & KF556228 & KF556615 \\
\hline L. flava & South Africa & Arts RSA 25/LL (JE) & ---------- & KF556233 & KF556000 \\
\hline L. flava & Sri Lanka (I) & $\begin{array}{l}\text { Schäfer-Verwimp \& } \\
\text { Verwimp } 15761 \\
\text { (GOET) }\end{array}$ & KF556428 & KF556184 & KF555959 \\
\hline
\end{tabular}




\begin{tabular}{|c|c|c|c|c|c|}
\hline L. flava & Sri Lanka (II) & $\begin{array}{l}\text { Schäfer-Verwimp \& } \\
\text { Verwimp } 5631 \\
\text { (GOET) }\end{array}$ & KF556456 & KF556220 & KF555990 \\
\hline L. flava & USA (I) & $\begin{array}{l}\text { Majestyk \& Wilbur } \\
9979 \text { (DUKE) }\end{array}$ & KF556476 & KF556240 & KF556618 \\
\hline L. flava & USA (II) & $\begin{array}{l}\text { Nelson et al. } 18549 \\
\text { (DUKE) }\end{array}$ & KF556477 & KF556241 & KF556007 \\
\hline $\begin{array}{l}\text { L. grossitexta } \\
\text { (Steph.) } \\
\text { M.E.Reiner \& Goda }\end{array}$ & Brazil, Paraná & $\begin{array}{l}\text { Schäfer-Verwimp \& } \\
\text { Verwimp } 10920 \\
\text { (GOET) }\end{array}$ & KF556490 & KF556255 & KF556019 \\
\hline L. grossitexta & Ecuador (I) & $\begin{array}{l}\text { Schäfer-Verwimp \& } \\
\text { Nebel } 31985 \text { (GOET) }\end{array}$ & KF556489 & KF556254 & KF556018 \\
\hline L. grossitexta & Ecuador (II) & $\begin{array}{l}\text { Schäfer-Verwimp \& } \\
\text { Nebel 32151/A } \\
\text { (GOET) }\end{array}$ & KF556488 & KF556253 & KF556017 \\
\hline L. grossitexta & Panama & $\begin{array}{l}\text { Schäfer-Verwimp \& } \\
\text { Verwimp } 31000 \\
\text { (GOET) }\end{array}$ & KF556491 & KF556256 & KF556020 \\
\hline $\begin{array}{l}\text { L. helmsiana } \\
\text { Steph. }\end{array}$ & New Zealand (I) & Renner 300050 (AK) & ----- & JF308567 & JF308538 \\
\hline L. helmsiana & New Zealand (II) & Renner 300069a (AK) & ---------- & JF308570 & JF308541 \\
\hline L. helmsiana & New Zealand (III) & Renner 300069 (AK) & ---------- & JF308569 & JF308540 \\
\hline L. hibernica Grolle & Ireland & Long 11743 (JE) & ---------- & KF556257 & KF556021 \\
\hline L. holtii Spruce & Madeira & $\begin{array}{l}\text { Drehwald \& Drehwald } \\
3719 \text { (GOET) }\end{array}$ & KF556492 & KF556258 & KF556022 \\
\hline $\begin{array}{l}\text { L. intricata J.B.Jack } \\
\text { \& Steph. }\end{array}$ & Ecuador & $\begin{array}{l}\text { Schäfer-Verwimp \& } \\
\text { Nebel } 33217 \text { (GOET) }\end{array}$ & ---------- & ---------- & KF556023 \\
\hline $\begin{array}{l}\text { L. isocalycina } \\
\text { (Nees.) Steph. }\end{array}$ & Bolivia & $\begin{array}{l}\text { Gradstein } 7492 \\
\text { (GOET) }\end{array}$ & KF556495 & KF556261 & KF556026 \\
\hline L. isocalycina & Brazil (I) & $\begin{array}{l}\text { Costa \& Gradstein } \\
3720 \text { (GOET) }\end{array}$ & KF556496 & KF556262 & KF556027 \\
\hline L. isocalycina & Brazil (II) & $\begin{array}{l}\text { Costa \& Gradstein } \\
3864 \text { (GOET) }\end{array}$ & KF556493 & KF556259 & KF556024 \\
\hline L. isocalycina & Brazil (III) & $\begin{array}{l}\text { Costa \& Gradstein } \\
3863 \text { (GOET) }\end{array}$ & KF556494 & KF556260 & KF556025 \\
\hline $\begin{array}{l}\text { L. isophylla } \\
\text { E.W.Jones }\end{array}$ & Madagascar & Lübenau 21 (EGR) & KF556497 & KF556263 & KF556028 \\
\hline L. japonica Mitt. & Japan (I) & Mizutani 15618 (L) & KF556499 & KF556265 & KF556030 \\
\hline L. japonica & Japan (II) & Mizutani 14074 (L) & KF556498 & KF556264 & KF556029 \\
\hline L. japonica & Russia & $\begin{array}{l}\text { Bakalin HRE } 63 \\
\text { (GOET) }\end{array}$ & KF556500 & KF556266 & KF556031 \\
\hline $\begin{array}{l}\text { L. laeta (Lehm. \& } \\
\text { Lindenb.) } \\
\text { Gottsche, Lindenb. } \\
\text { \& Nees }\end{array}$ & Ecuador & $\begin{array}{l}\text { Schäfer-Verwimp et } \\
\text { al. } 24412 \text { (GOET) }\end{array}$ & KF556501 & KF556267 & KF556032 \\
\hline
\end{tabular}




\begin{tabular}{|c|c|c|c|c|c|}
\hline $\begin{array}{l}\text { L. laetevirens Nees } \\
\text { \& Mont. }\end{array}$ & Argentina & Reiner MER 985 (JE) & ---------- & KF556278 & KF556040 \\
\hline L. laetevirens & Bolivia & $\begin{array}{l}\text { Linneo et al. } 533 \\
(\mathrm{MO})\end{array}$ & KF556505 & KF556271 & KF556034 \\
\hline L. laetevirens & Costa Rica (I) & $\begin{array}{l}\text { Schäfer-Verwimp \& } \\
\text { Holz SV/H-0315/A } \\
\text { (GOET) }\end{array}$ & ---------- & KF556274 & KF556623 \\
\hline L. laetevirens & Costa Rica (II) & $\begin{array}{l}\text { Schäfer-Verwimp \& } \\
\text { Holz SV/H-0406 } \\
\text { (GOET) }\end{array}$ & KF556507 & KF556273 & KF556036 \\
\hline L. laetevirens & Dominican Rep. (I) & $\begin{array}{l}\text { Schäfer-Verwimp \& } \\
\text { Verwimp } 27079 \\
\text { (GOET) }\end{array}$ & KF556508 & KF556275 & KF556037 \\
\hline L. laetevirens & Dominican Rep. (II) & $\begin{array}{l}\text { Schäfer-Verwimp \& } \\
\text { Verwimp } 27049 \\
\text { (GOET) }\end{array}$ & KF556502 & KF556268 & KF556033 \\
\hline L. laetevirens & Dominican Rep. (III) & $\begin{array}{l}\text { Schäfer-Verwimp \& } \\
\text { Verwimp 27009/A } \\
\text { (GOET) }\end{array}$ & KF556503 & KF556269 & KF556621 \\
\hline L. laetevirens & $\begin{array}{l}\text { Dominican Rep. } \\
\text { (IV) }\end{array}$ & $\begin{array}{l}\text { Schäfer-Verwimp \& } \\
\text { Verwimp } 27166 \\
\text { (GOET) }\end{array}$ & KF556509 & KF556276 & KF556038 \\
\hline L. laetevirens & Ecuador & $\begin{array}{l}\text { Schäfer-Verwimp \& } \\
\text { Nebel 31905/A } \\
\text { (GOET) }\end{array}$ & KF556504 & KF556270 & KF556622 \\
\hline L. laetevirens & French Guiana & $\begin{array}{l}\text { Holz FG00-311 } \\
\text { (GOET) }\end{array}$ & ----------- & KF556277 & KF556039 \\
\hline L. laetevirens & Madeira (I) & $\begin{array}{l}\text { Schäfer-Verwimp \& } \\
\text { Verwimp 26013A } \\
\text { (GOET) }\end{array}$ & KF556406 & KF556161 & KF555939 \\
\hline L. laetevirens & Madeira (II) & $\begin{array}{l}\text { Schäfer-Verwimp \& } \\
\text { Verwimp 26013B } \\
\text { (GOET) }\end{array}$ & KF556407 & KF556162 & KF555940 \\
\hline L. laetevirens & Mexico & $\begin{array}{l}\text { Gradstein \& } \\
\text { Velasquez s.n. } \\
\text { (GOET) }\end{array}$ & KF556506 & KF556272 & KF556035 \\
\hline $\begin{array}{l}\text { L. lamacerina } \\
\text { (Steph.) Schiffn. }\end{array}$ & Azores (I) & $\begin{array}{l}\text { Schäfer-Verwimp \& } \\
\text { Verwimp } 29394 \\
\text { (GOET) }\end{array}$ & KF556510 & KF556279 & KF556041 \\
\hline L. lamacerina & Azores (II) & $\begin{array}{l}\text { Schäfer-Verwimp \& } \\
\text { Verwimp 29325/A } \\
\text { (GOET) }\end{array}$ & KF556513 & KF556282 & KF556044 \\
\hline L. lamacerina & Canada & $\begin{array}{l}\text { Schofield \& Schofield } \\
95548 \text { (DUKE) }\end{array}$ & KF556514 & KF556283 & KF556045 \\
\hline L. lamacerina & Ireland & Long 11625 (JE) & ---------- & KF556286 & KF556047 \\
\hline L. lamacerina & Madeira (I) & Stech 04-297 (L) & KF556512 & KF556281 & KF556043 \\
\hline L. lamacerina & Madeira (II) & Stech 04-361 (L) & KF556511 & KF556280 & KF556042 \\
\hline L. Iamacerina & USA (I) & Risk 13222 (DUKE) & KF556515 & KF556284 & KF556624 \\
\hline
\end{tabular}




\begin{tabular}{|c|c|c|c|c|c|}
\hline L. lamacerina & USA (II) & Shaw 10368 (DUKE) & KF556516 & KF556285 & KF556046 \\
\hline $\begin{array}{l}\text { L. lomana } \\
\text { E.W.Jones }\end{array}$ & Réunion (I) & Pócs 08068/P (EGR) & KF556389 & KF556139 & KF556602 \\
\hline L. Iomana & Réunion (II) & Pócs 08064/L (EGR) & KF556388 & KF556138 & KF555921 \\
\hline $\begin{array}{l}\text { L. lumbricoides } \\
\text { (Nees) Nees }\end{array}$ & Indonesia & $\begin{array}{l}\text { Gradstein \& Ariyanti } \\
11028 \text { (GOET) }\end{array}$ & ---------- & KF556287 & KF556048 \\
\hline L. micholitzii Mizut. & Fiji Isls. (I) & $\begin{array}{l}\text { Pócs \& Pócs } \\
\text { 03288/DC (EGR) }\end{array}$ & KF556517 & KF556288 & KF556049 \\
\hline L. micholitzii & Fiji Isls. (II) & $\begin{array}{l}\text { Pócs \& Pócs 03309/L } \\
\text { (EGR) }\end{array}$ & KF556518 & KF556289 & KF556625 \\
\hline L. micholitzii & Indonesia & $\begin{array}{l}\text { Schäfer-Verwimp \& } \\
\text { Verwimp 24923/E } \\
\text { (GOET) }\end{array}$ & KF556519 & KF556290 & KF556050 \\
\hline L. microloba Taylor & Fiji Isls. (I) & $\begin{array}{l}\text { Pócs \& Pócs } \\
\text { 03280/CC (EGR) }\end{array}$ & --------- & KF556292 & KF556626 \\
\hline L. microloba & Fiji Isls. (II) & Pócs 08013/Y (EGR) & KF556520 & KF556291 & KF556051 \\
\hline L. microloba & Fiji Isls. (III) & $\begin{array}{l}\text { Pócs \& Pócs } \\
\text { 03279/CK (EGR) }\end{array}$ & KF556521 & KF556293 & KF556627 \\
\hline L. mimula Hürl. & Fiji Isls. (I) & Pócs 08013/M (EGR) & KF556522 & KF556294 & KF556628 \\
\hline L. mimula & Fiji Isls. (II) & Pócs 08034/E (EGR) & KF556523 & KF556295 & KF556052 \\
\hline L. mimula & Indonesia (I) & $\begin{array}{l}\text { Schäfer-Verwimp \& } \\
\text { Verwimp } 16973 \\
\text { (GOET) }\end{array}$ & KF556524 & KF556296 & KF556053 \\
\hline L. mimula & Indonesia (II) & $\begin{array}{l}\text { Schäfer-Verwimp } \\
20930 \text { (GOET) }\end{array}$ & AY548104 & DQ238580 & DQ987261 \\
\hline $\begin{array}{l}\text { L. minutiloba } \\
\text { A.Evans }\end{array}$ & Easter Island & $\begin{array}{l}\text { Ireland \& Bellolio } \\
30138(\mathrm{JE})\end{array}$ & KF556525 & KF556297 & KF556054 \\
\hline $\begin{array}{l}\text { L. monimiae } \\
\text { (Steph.) Steph. }\end{array}$ & Ecuador & $\begin{array}{l}\text { Schäfer-Verwimp \& } \\
\text { Preussing 23226/A } \\
\text { (GOET) }\end{array}$ & KF556526 & KF556298 & KF556055 \\
\hline $\begin{array}{l}\text { L. multidentata } \\
\text { M.E.Reiner \& } \\
\text { Mustelier }\end{array}$ & Dominican Rep. (I) & $\begin{array}{l}\text { Pócs \& Pócs 03157/A } \\
\text { (EGR) }\end{array}$ & KF556528 & KF556300 & KF556057 \\
\hline L. multidentata & Dominican Rep. (II) & $\begin{array}{l}\text { Pócs \& Pócs 03157/A } \\
\text { (EGR) }\end{array}$ & KF556527 & KF556299 & KF556056 \\
\hline $\begin{array}{l}\text { L. neelgherriana } \\
\text { Gottsche }\end{array}$ & Japan & Higuchi BSE 1295 (L) & ----------- & KF556301 & KF556058 \\
\hline $\begin{array}{l}\text { L. nepalensis } \\
\text { (Steph.) H.A.Mill., } \\
\text { Bonner \& Bischl. }\end{array}$ & Nepal & Long 17250 (JE) & & KF556302 & KF556059 \\
\hline L. obscura Mitt. & Malaysia & $\begin{array}{l}\text { Schäfer-Verwimp \& } \\
\text { Verwimp 18745/B } \\
\text { (GOET) }\end{array}$ & --------- & KF556304 & KF556060 \\
\hline L. obscura & Indonesia & $\begin{array}{l}\text { Schäfer-Verwimp \& } \\
\text { Verwimp } 16737 \\
\text { (GOET) }\end{array}$ & KF556530 & ---------- & KF556630 \\
\hline
\end{tabular}




\begin{tabular}{|c|c|c|c|c|c|}
\hline L. obtusangula & Bolivia (I) & $\begin{array}{l}\text { Gradstein } 9948 \\
\text { (GOET) }\end{array}$ & DQ983731 & DQ987428 & DQ987324 \\
\hline $\begin{array}{l}\text { L. obtusangula } \\
\text { Spruce }\end{array}$ & Bolivia (II) & Krömer 869 (GOET) & KF556532 & KF556307 & KF556063 \\
\hline L. obtusangula & Bolivia (III) & Krömer 1061 (GOET) & ---------- & KF556306 & KF556062 \\
\hline L. obtusangula & French Guiana & $\begin{array}{l}\text { Holz FG 00-291B } \\
\text { (GOET) }\end{array}$ & KF556531 & KF556305 & KF556061 \\
\hline $\begin{array}{l}\text { L. oligoclada } \\
\text { Spruce }\end{array}$ & Brazil (I) & $\begin{array}{l}\text { Schäfer-Verwimp \& } \\
\text { Verwimp } 13590 \\
\text { (GOET) }\end{array}$ & KF556533 & KF556308 & KF556064 \\
\hline L. oligoclada & Brazil (II) & $\begin{array}{l}\text { Schäfer-Verwimp \& } \\
\text { Verwimp } 10560 \\
\text { (GOET) }\end{array}$ & KF556534 & KF556310 & --- \\
\hline L. oligoclada & Brazil (III) & $\begin{array}{l}\text { Schäfer-Verwimp \& } \\
\text { Verwimp } 11780 \\
\text { (GOET) }\end{array}$ & ---------- & KF556309 & ----- \\
\hline $\begin{array}{l}\text { L. oracola } \\
\text { M.A.M.Renner }\end{array}$ & New Zealand (I) & Renner 299972 (AK) & ---- & JF308557 & JF308528 \\
\hline L. oracola & New Zealand (II) & Renner 300010 (AK) & ---------- & JF308560 & JF308531 \\
\hline L. oracola & New Zealand (III) & Renner 300078 (AK) & ----- & JF308571 & JF308542 \\
\hline L. oracola & New Zealand (IV) & Renner 300012 (AK) & $-\cdots$ & JF308561 & JF308532 \\
\hline L. oracola & New Zealand (V) & Renner 300003 (AK) & -------- & JF308559 & JF308530 \\
\hline $\begin{array}{l}\text { L. osculatiana De } \\
\text { Not. }\end{array}$ & Costa Rica & $\begin{array}{l}\text { Schäfer-Verwimp \& } \\
\text { Holz SV/H-0496/B } \\
\text { (GOET) }\end{array}$ & KF556539 & KF556315 & KF556068 \\
\hline L. osculatiana & Ecuador & $\begin{array}{l}\text { Schäfer-Verwimp et } \\
\text { al. } 24526 \text { (GOET) }\end{array}$ & KF556535 & KF556311 & KF556065 \\
\hline L. osculatiana & Panama & $\begin{array}{l}\text { Schäfer-Verwimp \& } \\
\text { Verwimp } 30958 \\
\text { (GOET) }\end{array}$ & KF556538 & KF556314 & KF556631 \\
\hline L. osculatiana & Venezuela & $\begin{array}{l}\text { Drehwald \& Reiner- } \\
\text { Drehwald } 40081 \\
\text { (GOET) }\end{array}$ & KF556537 & KF556313 & KF556067 \\
\hline L. pallescens Mitt. & Ecuador (I) & $\begin{array}{l}\text { Schäfer-Verwimp \& } \\
\text { Nebel } 32731 \text { (GOET) }\end{array}$ & KF556540 & ----------- & KF556069 \\
\hline L. pallescens & Ecuador (II) & $\begin{array}{l}\text { Schäfer-Verwimp \& } \\
\text { Nebel } 31824 \text { (GOET) }\end{array}$ & KF556541 & KF556316 & KF556070 \\
\hline $\begin{array}{l}\text { L. parva (S.Hatt.) } \\
\text { Mizut. }\end{array}$ & Japan (I) & Mizutani 16204 (L) & KF556543 & KF556319 & KF556073 \\
\hline L. parva & Japan (II) & Inoue 959 (JE) & & KF556317 & KF556071 \\
\hline L. parva & Japan (III) & Mizutani 15293 (L) & KF556542 & KF556318 & KF556072 \\
\hline $\begin{array}{l}\text { L. patriciae Schäf.- } \\
\text { Verw. }\end{array}$ & Malaysia & $\begin{array}{l}\text { Schäfer-Verwimp \& } \\
\text { Verwimp } 18583 \\
\text { (GOET) }\end{array}$ & ----- & KF556320 & KF556074 \\
\hline
\end{tabular}




\begin{tabular}{|c|c|c|c|c|c|}
\hline $\begin{array}{l}\text { L. paucidentata } \\
\text { (Steph.) Grolle }\end{array}$ & Cuba & $\begin{array}{l}\text { Pócs \& Caluff } \\
\text { 9199/CL (JE) }\end{array}$ & ----------- & KF556321 & KF556075 \\
\hline L. paucidentata & Dominica & $\begin{array}{l}\text { Schäfer- Verwimp } \\
17737 \text { (GOET) }\end{array}$ & DQ983695 & ----------- & DQ987345 \\
\hline $\begin{array}{l}\text { L. phyllobola Nees } \\
\text { \& Mont. }\end{array}$ & Ecuador & $\begin{array}{l}\text { Noeske et al. } 204 \\
\text { (GOET) }\end{array}$ & KF556600 & KF556322 & KF556076 \\
\hline L. phyllobola & Kenya & $\begin{array}{l}\text { Pócs \& Pócs 04009/B } \\
\text { (EGR) }\end{array}$ & KF556544 & KF556323 & KF556632 \\
\hline $\begin{array}{l}\text { L. pterigonia } \\
\text { (Lehm. \& Lindenb.) } \\
\text { Schiffn. }\end{array}$ & Bolivia (I) & $\begin{array}{l}\text { Churchill et al. } 21851 \\
\text { (GOET) }\end{array}$ & KF556546 & KF556325 & KF556078 \\
\hline L. pterigonia & Bolivia (II) & $\begin{array}{l}\text { Gradstein } 9963 \\
\text { (GOET) }\end{array}$ & KF556548 & KF556327 & KF556080 \\
\hline $\begin{array}{l}\text { L. pterigonia } \\
\text { (Lehm. \& Lindenb.) } \\
\text { Mont. }\end{array}$ & Bolivia (III) & $\begin{array}{l}\text { Gradstein } 9964 \\
\text { (GOET) }\end{array}$ & DQ983732 & DQ987429 & DQ987325 \\
\hline L. pterigonia & Bolivia (IV) & $\begin{array}{l}\text { Churchill et al. } 23467 \\
\text { (GOET) }\end{array}$ & KF556547 & KF556326 & KF556079 \\
\hline L. pterigonia & Brazil & $\begin{array}{l}\text { Costa \& Gradstein } \\
3867 \text { (GOET) }\end{array}$ & KF556545 & KF556324 & KF556077 \\
\hline L. pterigonia & Ecuador & Nöske 164 (GOET) & KF556549 & KF556328 & KF556081 \\
\hline $\begin{array}{l}\text { L. puiggariana } \\
\text { Steph. }\end{array}$ & Dominican Rep. (I) & $\begin{array}{l}\text { Schäfer-Verwimp \& } \\
\text { Verwimp 27016/A } \\
\text { (GOET) }\end{array}$ & KF556550 & KF556329 & KF556082 \\
\hline L. puiggariana & Dominican Rep. (II) & $\begin{array}{l}\text { Schäfer-Verwimp \& } \\
\text { Verwimp 27215/A } \\
\text { (GOET) }\end{array}$ & KF556551 & KF556330 & KF556083 \\
\hline $\begin{array}{l}\text { L. pulverulenta } \\
\text { (Gottsche ex } \\
\text { Steph.) M.E.Reiner }\end{array}$ & Bolivia & $\begin{array}{l}\text { Reiner-Drehwald \& } \\
\text { Drehwald } 4517 \\
\text { (GOET) }\end{array}$ & KF556552 & KF556331 & KF556084 \\
\hline $\begin{array}{l}\text { L. ramosossima } \\
\text { Steph. }\end{array}$ & $\begin{array}{l}\text { São Tomé and } \\
\text { Príncipe (I) }\end{array}$ & $\begin{array}{l}\text { Shevock } 34551 \\
\text { (EGR) }\end{array}$ & ---------- & KF556334 & KF556087 \\
\hline L. ramosissima & $\begin{array}{l}\text { São Tomé and } \\
\text { Príncipe (II) }\end{array}$ & $\begin{array}{l}\text { Shevock 34348A } \\
\text { (EGR) }\end{array}$ & KF556554 & KF556333 & KF556086 \\
\hline L. ramosissima & $\begin{array}{l}\text { São Tomé and } \\
\text { Príncipe (III) }\end{array}$ & $\begin{array}{l}\text { Shevock } 34451 \\
\text { (EGR) }\end{array}$ & KF556553 & KF556332 & KF556085 \\
\hline $\begin{array}{l}\text { L. ramulosa } \\
\text { (Herzog) } \\
\text { R.M.Schust. }\end{array}$ & Costa Rica & $\begin{array}{l}\text { Schäfer-Verwimp \& } \\
\text { Holz SV/H-0229/A } \\
\text { (GOET) }\end{array}$ & KF556555 & KF556335 & KF556088 \\
\hline L. ramulosa & Dominican Rep. & $\begin{array}{l}\text { Schäfer-Verwimp \& } \\
\text { Verwimp } 26954 \\
\text { (GOET) }\end{array}$ & ----------- & KF556337 & KF556633 \\
\hline L. ramulosa & Ecuador (I) & $\begin{array}{l}\text { Wilson et al. 04-24 } \\
\text { (GOET) }\end{array}$ & KF556556 & KF556336 & KF556089 \\
\hline L. ramulosa & Ecuador (II) & $\begin{array}{l}\text { Schäfer-Verwimp et } \\
\text { al. } 24208 \text { (GOET) }\end{array}$ & KF556557 & KF556338 & KF556090 \\
\hline $\begin{array}{l}\text { L. reflexistipula } \\
\text { (Lehm. \& Lindenb.) } \\
\text { Gottsche, Lindenb. } \\
\text { \& Nees }\end{array}$ & Brazil & $\begin{array}{l}\text { Schäfer-Verwimp \& } \\
\text { Verwimp } 12482 \\
\text { (GOET) }\end{array}$ & KF556558 & KF556339 & KF556091 \\
\hline
\end{tabular}




\begin{tabular}{|c|c|c|c|c|c|}
\hline L. reflexistipula & Ecuador (I) & $\begin{array}{l}\text { Schäfer-Verwimp \& } \\
\text { Nebel } 31707 \text { (GOET) }\end{array}$ & KF556560 & KF556341 & KF556093 \\
\hline L. reflexistipula & Ecuador (II) & $\begin{array}{l}\text { Schäfer-Verwimp et } \\
\text { al. 24215/A (GOET) }\end{array}$ & KF556563 & KF556344 & KF556096 \\
\hline L. reflexistipula & Ecuador (III) & $\begin{array}{l}\text { Schäfer-Verwimp \& } \\
\text { Nebel } 33162 \text { (GOET) }\end{array}$ & KF556559 & KF556340 & KF556092 \\
\hline L. reflexistipula & Ecuador (IV) & $\begin{array}{l}\text { Schäfer-Verwimp \& } \\
\text { Nebel } 32032 \text { (GOET) }\end{array}$ & KF556561 & KF556342 & KF556094 \\
\hline L. reflexistipula & Peru & $\begin{array}{l}\text { Drehwald } 10046 \\
\text { (GOET) }\end{array}$ & KF556562 & KF556343 & KF556095 \\
\hline $\begin{array}{l}\text { L. reflexistipula var. } \\
\text { costaricensis } \\
\text { (Steph.) } \\
\text { M.E.Reiner }\end{array}$ & Costa Rica & $\begin{array}{l}\text { Schäfer-Verwimp \& } \\
\text { Holz SV/H-0434 } \\
\text { (GOET) }\end{array}$ & KF556565 & KF556346 & KF556098 \\
\hline $\begin{array}{l}\text { L. reflexistipula var. } \\
\text { costaricensis }\end{array}$ & Panama & $\begin{array}{l}\text { Schäfer-Verwimp \& } \\
\text { Verwimp } 30930 \\
\text { (GOET) }\end{array}$ & KF556564 & KF556345 & KF556097 \\
\hline $\begin{array}{l}\text { L. rhigophila } \\
\text { M.A.M.Renner }\end{array}$ & New Zealand & Renner 300147 (AK) & ------- & JF308579 & JF308550 \\
\hline L. rhigophila & New Zealand & Renner 300044a (AK) & ---- & JF308566 & JF308537 \\
\hline L. rhigophila & New Zealand & Renner 300149 (AK) & ----- & JF308580 & JF308551 \\
\hline L. rotundifolia Mitt. & $\begin{array}{l}\text { Costa Rica, } \\
\text { Cartago }\end{array}$ & $\begin{array}{l}\text { Schäfer-Verwimp \& } \\
\text { Holz SV/H-0378 } \\
\text { (GOET) }\end{array}$ & KF556567 & KF556348 & KF556099 \\
\hline L. rotundifolia & Ecuador & $\begin{array}{l}\text { Gradstein } 10172 \\
\text { (GOET) }\end{array}$ & DQ983734 & DQ987410 & DQ987304 \\
\hline L. rotundifolia & Panama, Chiriqui & $\begin{array}{l}\text { Schäfer-Verwimp \& } \\
\text { Verwimp } 31029 \\
\text { (GOET) }\end{array}$ & KF556568 & KF556349 & KF556100 \\
\hline $\begin{array}{l}\text { L. ruthii (A.Evans) } \\
\text { R.M.Schust. }\end{array}$ & $\begin{array}{l}\text { USA (I), North } \\
\text { Carolina }\end{array}$ & Duell 1411 p.p. (JE) & --------- & KF556350 & KF556101 \\
\hline L. ruthii & USA (II), Tennessee & Zartman 681 (DUKE) & KF556569 & ---------- & KF556634 \\
\hline $\begin{array}{l}\text { L. sordida (Nees) } \\
\text { Nees }\end{array}$ & Fiji Isls. (I) & $\begin{array}{l}\text { Pócs \& Pócs } \\
\text { 03300/AP (EGR) }\end{array}$ & KF556570 & KF556351 & KF556102 \\
\hline L. sordida & Fiji Isls. (II) & $\begin{array}{l}\text { Pócs \& Pócs 03305/J } \\
\text { (EGR) }\end{array}$ & KF556572 & KF556353 & KF556104 \\
\hline L. sordida & Fiji Isls. (III) & $\begin{array}{l}\text { Pócs \& Pócs 03305/J } \\
\text { (EGR) }\end{array}$ & KF556571 & KF556352 & KF556103 \\
\hline L. sordida & Indonesia & Sporn 101 (GOET) & KF556574 & KF556355 & KF556106 \\
\hline L. sordida & Japan & $\begin{array}{l}\text { Yamaguchi } 29848 \\
\text { (GOET) }\end{array}$ & KF556575 & KF556356 & KF556107 \\
\hline L. sordida & Papua New Guinea & Streimann 41611 (JE) & KF556573 & KF556354 & KF556110 \\
\hline $\begin{array}{l}\text { L. sporadica } \\
\text { Besch. \& Spruce }\end{array}$ & Panama & $\begin{array}{l}\text { Schäfer-Verwimp \& } \\
\text { Verwimp } 31033 \\
\text { (GOET) }\end{array}$ & KF556583 & ---------- & KF556117 \\
\hline
\end{tabular}




\begin{tabular}{|c|c|c|c|c|c|}
\hline $\begin{array}{l}\text { L. subspathulata } \\
\text { Spruce }\end{array}$ & Colombia & $\begin{array}{l}\text { Gradstein } 8991 \\
\text { (GOET) }\end{array}$ & KF556584 & KF556366 & KF556118 \\
\hline L. subspathulata & Dominica & $\begin{array}{l}\text { Gradstein } 6643 \\
\text { (GOET) }\end{array}$ & KF556585 & KF556367 & KF556119 \\
\hline $\begin{array}{l}\text { L. tapajosensis } \\
\text { Spruce }\end{array}$ & Ecuador & $\begin{array}{l}\text { Nöske et al. } 204 \\
\text { (GOET) }\end{array}$ & KF556589 & KF556371 & KF556122 \\
\hline $\begin{array}{l}\text { L. tasmanica } \\
\text { Gottsche }\end{array}$ & New Zealand & $\begin{array}{l}\text { Renner } 872054 \\
\text { (NSW) }\end{array}$ & ---------- & $J F 308581$ & JF308552 \\
\hline $\begin{array}{l}\text { L. topoensis } \\
\text { Gradst. \& } \\
\text { M.E.Reiner }\end{array}$ & Ecuador (I) & $\begin{array}{l}\text { Gradstein \& Jost } \\
10163 \text { (GOET) }\end{array}$ & KF556590 & KF556372 & KF556123 \\
\hline L. topoensis & Ecuador (II) & $\begin{array}{l}\text { Gradstein \& Jost } \\
10063 \text { (GOET) }\end{array}$ & DQ983712 & DQ987416 & DQ987312 \\
\hline L. topoensis & Ecuador (III) & $\begin{array}{l}\text { Gradstein \& Jost } \\
\text { 10063a (GOET) }\end{array}$ & KF556591 & KF556373 & KF556124 \\
\hline L. topoensis & Ecuador (IV) & $\begin{array}{l}\text { Wilson et al 04-04 } \\
\text { (GOET) }\end{array}$ & DQ983733 & DQ987435 & DQ987331 \\
\hline $\begin{array}{l}\text { L. trinitensis } \\
\text { Lindenb. \& } \\
\text { Gottsche }\end{array}$ & Bolivia & $\begin{array}{l}\text { Linneo et al. } 82 \\
\text { (GOET) }\end{array}$ & KF556593 & KF556375 & KF556126 \\
\hline L. trinitensis & Brazil & Vital 10.168 (JE) & KF556594 & KF556376 & KF556127 \\
\hline L. trinitensis & Mayotte & $\begin{array}{l}\text { Pócs \& Pócs 05097/C } \\
\text { (EGR) }\end{array}$ & KF556592 & KF556374 & KF556125 \\
\hline $\begin{array}{l}\text { L. tuberculosa } \\
\text { Steph. }\end{array}$ & $\begin{array}{l}\text { São Tomé and } \\
\text { Príncipe (I) }\end{array}$ & $\begin{array}{l}\text { Pócs \& Pócs } 34690 \\
\text { (EGR) }\end{array}$ & KF556595 & KF556377 & KF556128 \\
\hline L. tuberculosa & $\begin{array}{l}\text { São Tomé and } \\
\text { Príncipe (II) }\end{array}$ & $\begin{array}{l}\text { Shevock } 34776 \\
\text { (EGR) }\end{array}$ & KF556483 & KF556247 & KF556012 \\
\hline L. tuberculosa & Thailand & $\begin{array}{l}\text { Schäfer-Verwimp \& } \\
\text { Verwimp } 23880 \\
\text { (GOET) }\end{array}$ & KF556457 & KF556221 & KF555991 \\
\hline L. tumida Mitt. & New Zealand (I) & Renner 299949 (AK) & ----------- & JF308556 & JF308527 \\
\hline L. tumida & New Zealand (II) & Renner 300002 (AK) & ---------- & JF308558 & JF308529 \\
\hline $\begin{array}{l}\text { L. umbilicata } \\
\text { (Nees) Nees et al. }\end{array}$ & Indonesia (I) & $\begin{array}{l}\text { Gradstein } 12076 \\
\text { (GOET) }\end{array}$ & KF556598 & KF556380 & KF556131 \\
\hline L. umbilicata & Indonesia (II) & Gradstein 51 (GOET) & KF556599 & KF556381 & KF556132 \\
\hline L. umbilicata & Indonesia (III) & $\begin{array}{l}\text { Schäfer-Verwimp \& } \\
\text { Verwimp 20794/B } \\
\text { (GOET) }\end{array}$ & KF556596 & KF556378 & KF556129 \\
\hline L. umbilicata & Indonesia (IV) & $\begin{array}{l}\text { Schäfer-Verwimp \& } \\
\text { Verwimp } 16954 \\
\text { (GOET) }\end{array}$ & KF556597 & KF556379 & KF556130 \\
\hline $\begin{array}{l}\text { L. wallichiana } \\
\text { Gottsche }\end{array}$ & Nepal & Long 16716 (JE) & ----- & KF556382 & - \\
\hline L.sp. I & Ecuador & $\begin{array}{l}\text { Schäfer-Verwimp \& } \\
\text { Preussing } 23533 \\
\text { (GOET) }\end{array}$ & KF556536 & KF556312 & KF556066 \\
\hline L.sp. II & Bolivia & $\begin{array}{l}\text { Fuentes \& Aldana } \\
6473 \text { (GOET) }\end{array}$ & KF556429 & KF556185 & KF555960 \\
\hline
\end{tabular}




\begin{tabular}{|c|c|c|c|c|c|}
\hline L. sp. III & Gough Island & $\begin{array}{l}\text { Gremmen 2000-0075 } \\
\text { (EGR) }\end{array}$ & KF556579 & KF556361 & KF556112 \\
\hline L. sp. IV & Fiji Isls. & Pócs 08029/O (EGR) & KF556580 & KF556362 & KF556113 \\
\hline L. sp. V & Madagascar & Geissler 3498 (EGR) & KF556578 & KF556360 & KF556111 \\
\hline L. sp. VI & Panama & $\begin{array}{l}\text { Schäfer-Verwimp \& } \\
\text { Verwimp } 30834 \\
\text { (GOET) }\end{array}$ & KF556582 & KF556365 & KF556116 \\
\hline L. sp. VII & Nepal & Pölt H3071 (JE) & ----------- & KF556363 & KF556114 \\
\hline L. sp.VIII & Ethiopia & Hylander 5564 (EGR) & KF556576 & KF556357 & KF556108 \\
\hline L. sp. IX & $\begin{array}{l}\text { São Tomé and } \\
\text { Príncipe }\end{array}$ & $\begin{array}{l}\text { Shevock et al. } 34316 \\
\text { (EGR) }\end{array}$ & KF556485 & KF556249 & KF556014 \\
\hline L. sp. X & Madagascar & $\begin{array}{l}\text { Pócs et al. 90100/C } \\
\text { (JE) }\end{array}$ & KF556581 & KF556364 & KF556115 \\
\hline $\begin{array}{l}\text { Lepidolejeunea } \\
\text { bidentula (Steph.) } \\
\text { R.M.Schust. }\end{array}$ & China & $\begin{array}{l}\text { Koponen et al. } 51525 \\
(\mathrm{H})\end{array}$ & AY125936 & AY144476 & AY125340 \\
\hline $\begin{array}{l}\text { Lep. eluta (Nees) } \\
\text { R.M.Schust. }\end{array}$ & Bolivia (I) & $\begin{array}{l}\text { Churchill \& Vasquez } \\
2180 \text { (GOET) }\end{array}$ & AY548066 & DQ238579 & DQ987266 \\
\hline Lep. eluta & Bolivia (II) & $\begin{array}{l}\text { Drehwald } 4833 \\
\text { (GOET) }\end{array}$ & DQ983696 & DQ987379 & DQ987257 \\
\hline $\begin{array}{l}\text { Lep. integristipula } \\
\text { (J.B.Jack \& Steph.) } \\
\text { R.M.Schust. }\end{array}$ & Fiji Isls. & $\begin{array}{l}\text { Pócs 03307/AC } \\
\text { (GOET) }\end{array}$ & DQ983697 & DQ987417 & DQ987313 \\
\hline $\begin{array}{l}\text { Microlejeunea. } \\
\text { africana Steph. }\end{array}$ & Madagascar & Lübenau 2 (JE) & KC313149 & KC313189 & KC313111 \\
\hline M. africana & $\begin{array}{l}\text { São Tomé and } \\
\text { Príncipe (I) }\end{array}$ & $\begin{array}{l}\text { Shevock 34576A } \\
\text { (GOET) }\end{array}$ & KC313150 & KC313190 & KC313112 \\
\hline M. Africana & $\begin{array}{l}\text { São Tomé and } \\
\text { Príncipe (II) }\end{array}$ & $\begin{array}{l}\text { Shevock 34576B } \\
\text { (GOET) }\end{array}$ & KC313151 & KC313191 & KC313113 \\
\hline $\begin{array}{l}\text { M. capillaris } \\
\text { (Gottsche) Steph. }\end{array}$ & Costa Rica & $\begin{array}{l}\text { Schäfer-Verwimp \& } \\
\text { Holz SV/H-0489/B } \\
\text { (JE) }\end{array}$ & KC313152 & KC313192 & KC313114 \\
\hline $\begin{array}{l}\text { M. colombiana } \\
\text { Bischl. }\end{array}$ & Dominican Rep. & $\begin{array}{l}\text { Schäfer-Verwimp \& } \\
\text { Verwimp 26614/A } \\
\text { (JE) }\end{array}$ & KC313153 & KC313193 & KC313079 \\
\hline $\begin{array}{l}\text { M. filicuspis } \\
\text { (Steph.) Heinrichs, } \\
\text { Schäf.-Verw., Pócs } \\
\text { \& S.Dong }\end{array}$ & Fiji Isls. (I) & $\begin{array}{l}\text { Pócs \& Pócs 03306/R } \\
\text { (EGR) }\end{array}$ & KC313137 & KC313177 & KC313099 \\
\hline M. filicuspis & Fiji Isls. (II) & $\begin{array}{l}\text { Pócs \& Pócs 03304/A } \\
\text { (EGR) }\end{array}$ & KC313138 & KC313178 & KC313100 \\
\hline M. filicuspis & Thailand & $\begin{array}{l}\text { Pócs \& Pócs 07006/A } \\
\text { (EGR) }\end{array}$ & KC313139 & KC313179 & KC313101 \\
\hline $\begin{array}{l}\text { M. fischeri (Tixier) } \\
\text { Heinrichs, Schäf.- } \\
\text { Verw., Pócs \& } \\
\text { S.Dong }\end{array}$ & Uganda (I) & $\begin{array}{l}\text { Pócs \& Lye 97141/T } \\
\text { (EGR) }\end{array}$ & KC313140 & KC313180 & KC313102 \\
\hline
\end{tabular}




\begin{tabular}{|c|c|c|c|c|c|}
\hline M. fischeri & Uganda (II) & $\begin{array}{l}\text { Pócs \& Lye } \\
\text { 97142/AM (EGR) }\end{array}$ & KC313141 & KC313181 & KC313103 \\
\hline M. fischeri & Uganda (III) & $\begin{array}{l}\text { Pócs \& Lye 97142/BB } \\
\text { (EGR) }\end{array}$ & KC313142 & KC313182 & KC313104 \\
\hline M. fischeri & Uganda (IV) & $\begin{array}{l}\text { Pócs \& Lye 97142/BQ } \\
\text { (EGR) }\end{array}$ & KC313143 & KC313183 & KC313105 \\
\hline \multicolumn{6}{|l|}{ M. latitans (Hook.f. } \\
\hline $\begin{array}{l}\text { \& Taylor) Heinrichs, } \\
\text { Schäf.-Verw., Pócs }\end{array}$ & New Zealand & $\begin{array}{l}\text { Schäfer-Verwimp \& } \\
\text { Verwimp } 13869 \text { (JE) }\end{array}$ & KC313146 & KC313186 & KC313108 \\
\hline \multicolumn{6}{|l|}{ \& S.Dong } \\
\hline M. sp. & Thailand & $\begin{array}{l}\text { Schäfer-Verwimp \& } \\
\text { Verwimp } 16293 \\
\text { (GOET) }\end{array}$ & ----------- & KC313196 & KC313117 \\
\hline $\begin{array}{l}\text { M. squarrosa } \\
\text { (Steph.), Heinrichs, } \\
\text { Schäf.-Verw., Pócs } \\
\text { \& S.Dong }\end{array}$ & Brazil (I) & $\begin{array}{l}\text { Schäfer-Verwimp \& } \\
\text { Verwimp } 14780 \text { (JE) }\end{array}$ & KC313157 & KC313197 & KC313118 \\
\hline M. squarrosa & Brazil (II) & $\begin{array}{l}\text { Schäfer-Verwimp \& } \\
\text { Verwimp } 14638 \text { (JE) }\end{array}$ & KC313158 & KC313198 & KC313119 \\
\hline M. squarrosa & Brazil (III) & $\begin{array}{l}\text { Schäfer-Verwimp \& } \\
\text { Verwimp } 13376 \\
\text { (GOET) }\end{array}$ & DQ983720 & DQ987446 & DQ987344 \\
\hline $\begin{array}{l}\text { M. ulicina (Taylor) } \\
\text { Steph. }\end{array}$ & La Palma (I) & $\begin{array}{l}\text { Schäfer-Verwimp \& } \\
\text { Verwimp } 24800 \\
\text { (GOET) }\end{array}$ & KC313154 & KC313194 & KC313115 \\
\hline M. ulicina & La Palma (II) & $\begin{array}{l}\text { Schäfer-Verwimp \& } \\
\text { Verwimp } 24666 \\
\text { (GOET) }\end{array}$ & KC313155 & KC313195 & KC313116 \\
\hline
\end{tabular}




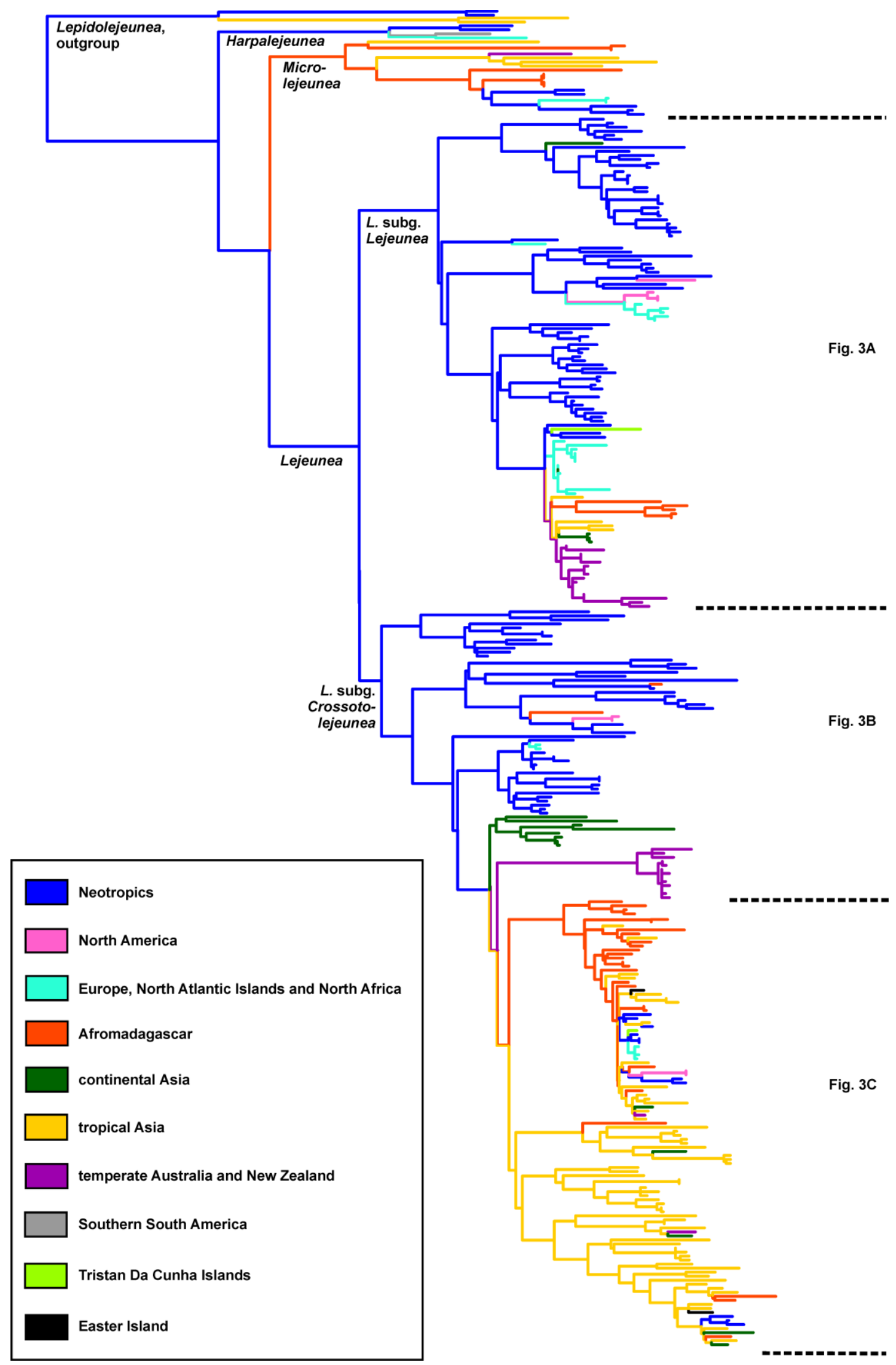

Figure 2.

Condensed Maximum Likelihood phylogeny of the Harpalejeunea-Lejeunea-Microlejeunea clade. Branch colors correspond to the most parsimonious reconstruction of ancestral areas of distribution and provide evidence for a Neotropical origin of Lejeunea. 


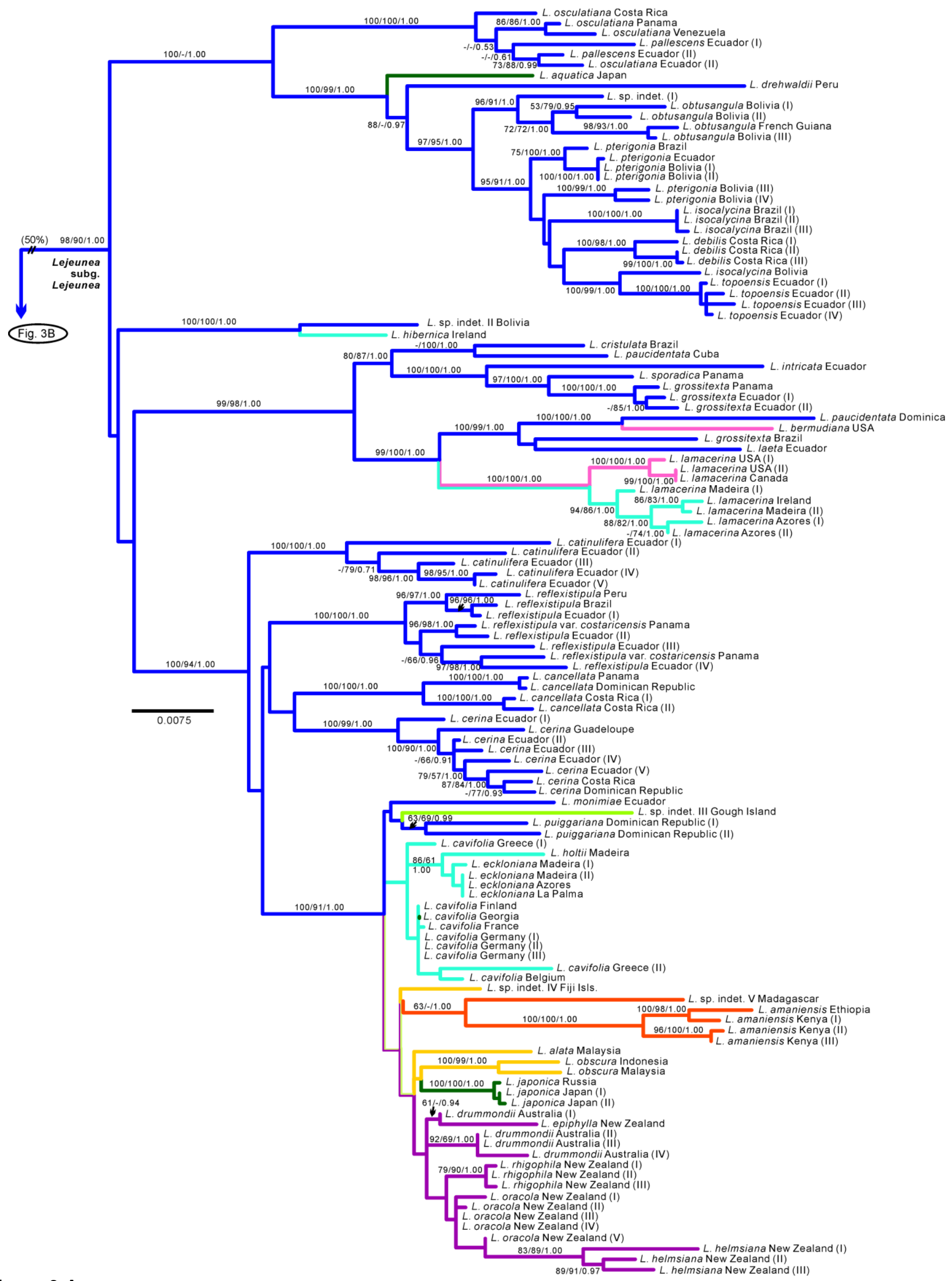

Figure 3 A.

Pruned Lejeunea clade from Fig. 2. Fifty nine Lejeunea species are represented by multiple accessions, 29 of these are monophyletic, 25 para- or polyphyletic. 


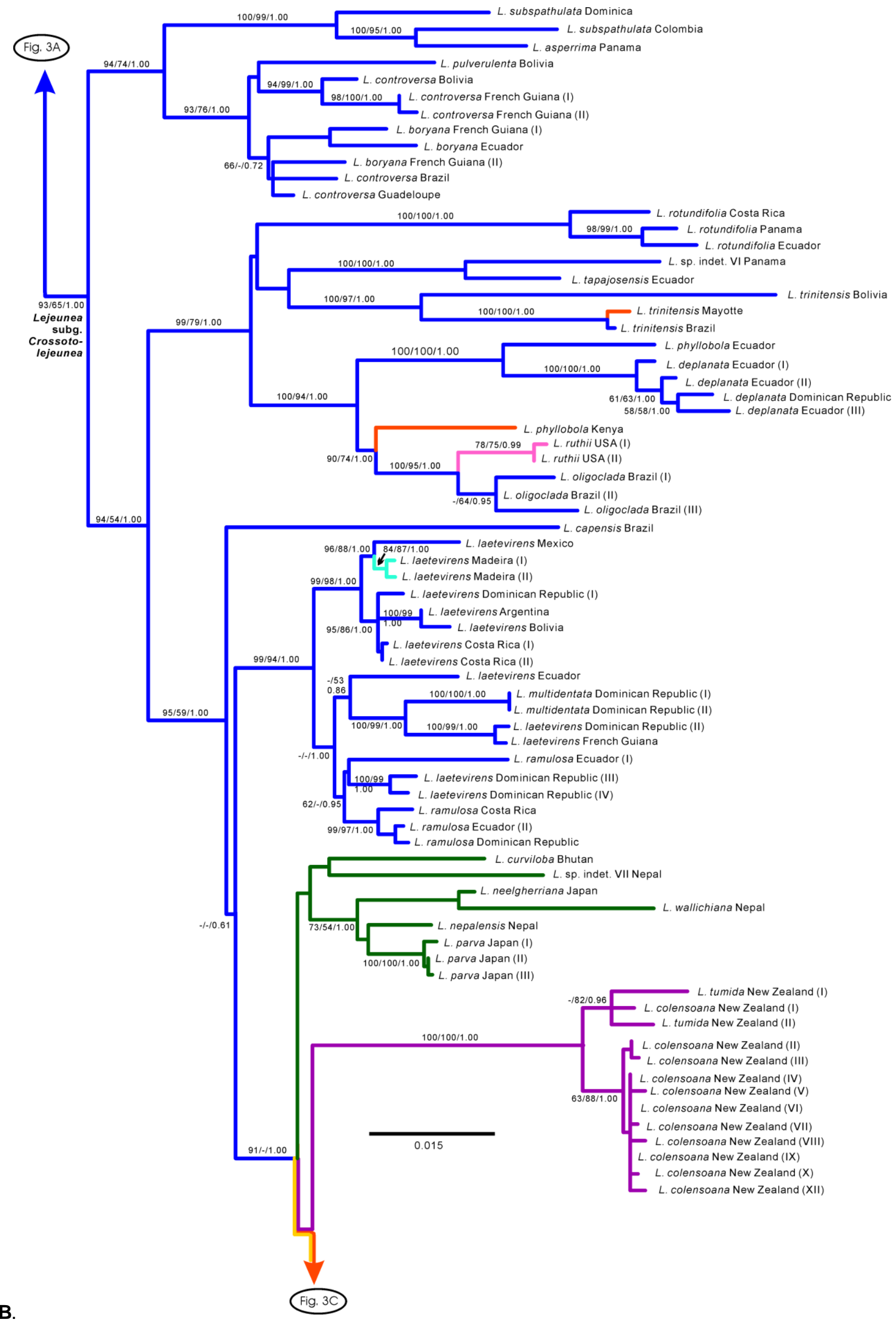

Figure 3 B.

Pruned Lejeunea clade from Fig. 2. Fifty nine Lejeunea species are represented by multiple accessions, 29 of these are monophyletic, 25 para- or polyphyletic. 


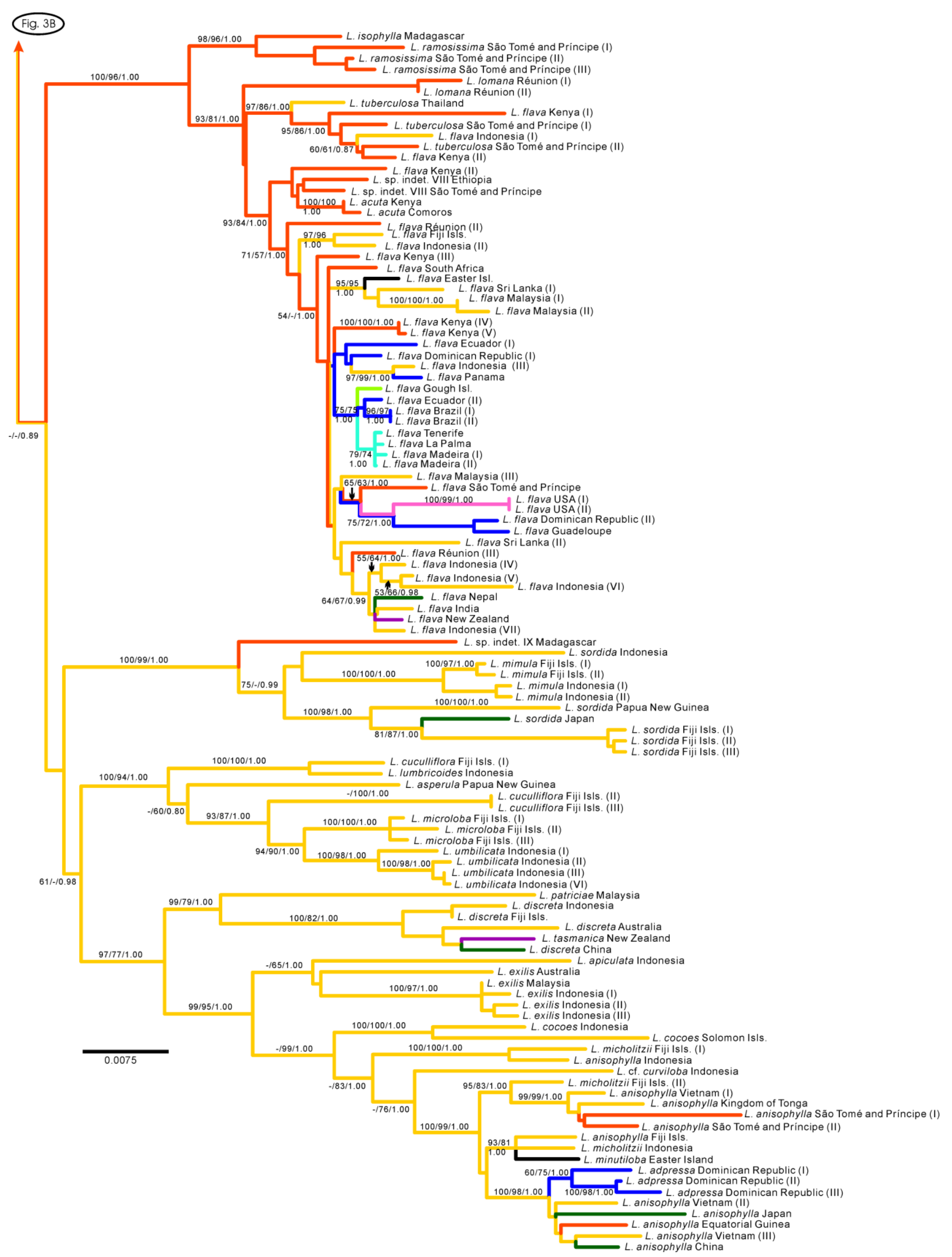

\section{Figure $3 \mathrm{C}$.}

Pruned Lejeunea clade from Fig. 2. Fifty nine Lejeunea species are represented by multiple accessions, 29 of these are monophyletic, 25 para- or polyphyletic. 


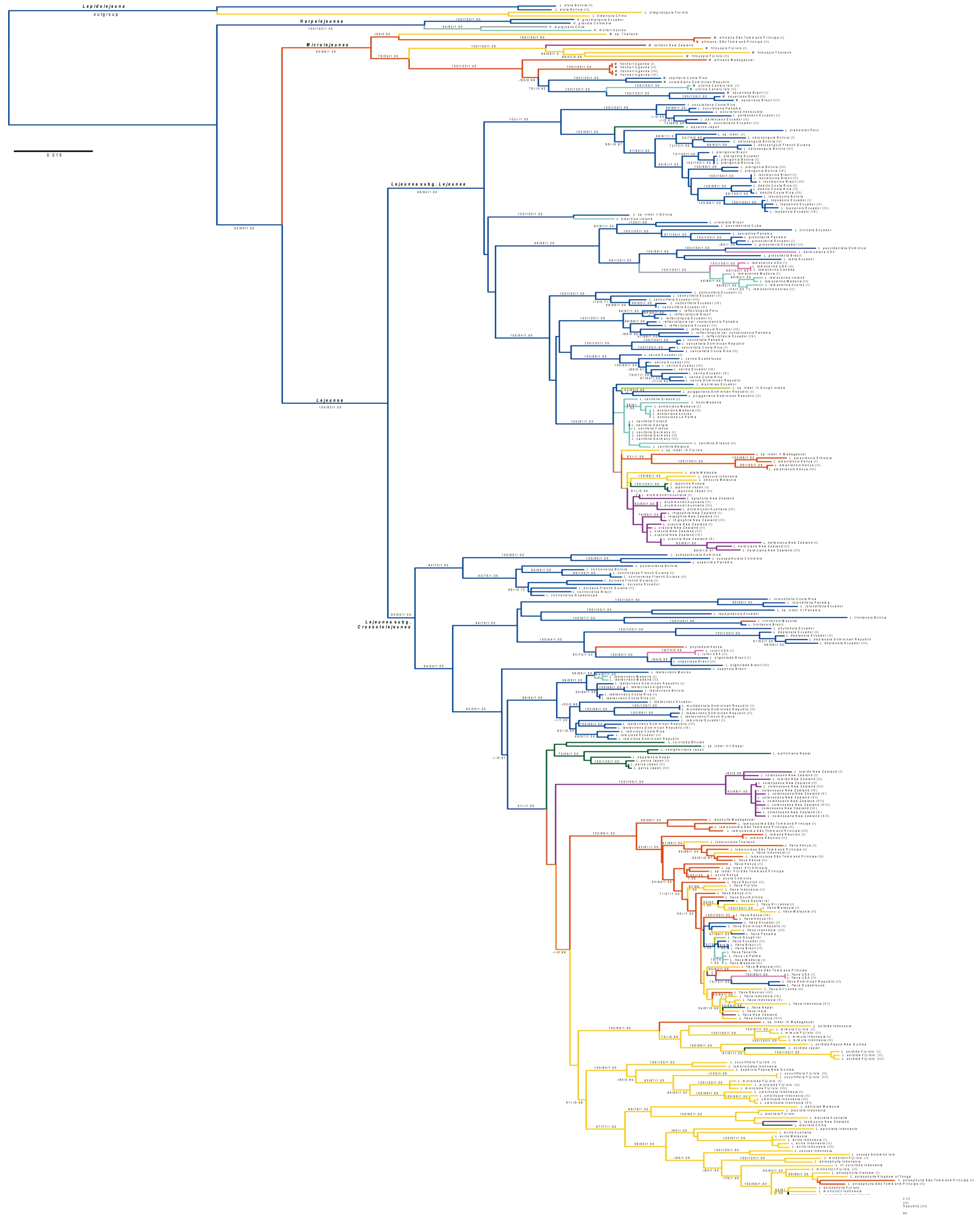

Figure S1. Maximum Likelihood phylogeny of the Harpalejeunea-Lejeunea-Microlejeunea clade. ML and MP bootstrap percentage values as well as Bayesian Posterior Probabilities are indicated at branches. Branch colors correspond to the most parsimonious reconstruction of ancestral areas of distribution 


\section{Appendix 3}

\section{Size doesn't matter - recircumscription of Microlejeunea (Lejeuneaceae, Porellales) based on molecular and morphological evidence}

Shanshan Dong, Alfons-Schäfer-Verwimp, Tamás Pócs, Kathrin Feldberg, Aleksandra Czumaj, Alexander R. Schmidt, Harald Schneider, Jochen Heinrichs

Published in Phytotaxa, 2013, 85, 41-55. 


\section{Abstract}

Phylogenetic analyses of a three marker dataset of Lejeuneaceae (chloroplast genome $r b c L$ gene and $t r n L-F$ region, and nuclear ribosomal ITS1-5.8S-ITS2 region) resolve the "Lejeunea complex" in three main lineages assigned here to Harpalejeunea, Lejeunea and Microlejeunea. The taxa Harpalejeunea fischeri, H. filicuspis, H. latitans and Pluvianthus squarrosus are nested in a clade with several representatives of Microlejeunea including the generitype $M$. africana, and are transferred to the latter genus. Harpalejeunea and Microlejeunea differ from Lejeunea by the presence of ocelli. Harpalejeunea has diverging, blunt underleaf lobes in contrast to the forward directed, blunt to acute underleaf lobes of Microlejeunea. Morphologically similar accessions of Microlejeunea form independent lineages. Drepanolejeunea vandenberghenii is newly reported for Madagascar, Malawi and Réunion.

Key words: cryptic speciation, Drepanolejeunea, Harpalejeunea, Jungermanniopsida, Lejeunea, liverwort, Pluvianthus, taxonomy

\section{Introduction}

Lejeunea Libert (1820: 372) is a species rich and taxonomically complex genus of Lejeuneeae with some 1700 species described worldwide (Reiner-Drehwald 1999). The high number of Lejeunea species is due to the wide genus concept of early authors including Gottsche et al. (1844-1847) and Spruce (1884). Later authors placed Lejeunea elements sensu Spruce in more than 60 different genera (Gradstein et al. 2004), leading to tentative estimates of species numbers "over 100"; the exact number being unclear due to a lack of comprehensive taxonomic studies (Gradstein \& Pinheiro da Costa 2003). Molecular phylogenetic studies resolved several of the segregate genera as nested within Lejeunea, e.g. Taxilejeunea (Spruce 1884: 212) Schiffner (1893: 125), Macrolejeunea (Spruce 1884: 224) Schiffner (1893: 118) (Wilson et al. 2007) and Sphaerolejeunea Herzog (1938: 88), results that support a wider genus concept (Heinrichs et al. 2012a). Currently Lejeunea is considered to be a morphologically heterogeneous genus with unclear boundaries (Gradstein et al. 2001). 
Microlejeunea Stephani (1888: 61) has been treated either as a genus (Bischler et al. 1963, Grolle 1995, Ah-Peng \& Bardat 2011) or as a subgenus of Lejeunea (Schuster 1980, Thiers 1997). It differs from Lejeuneas.str. by sinuose stems, presence of three medullary cells, perpendicular branching, large lobules being usually longer than wide, small underleaves, bracts being larger than the leaves and often shortly connate at their bases, male bracts being distinctly larger than the leaves (Bischler et al. 1962), a tendency to produce ocelli (Schuster 1957), and the presence of lejeuneoid subgynoecial innovations (Grolle 1995). In some molecular phylogenetic analyses of Lejeuneaceae, Microlejeunea was placed sister to Lejeunea (Ahonen et al. 2003, Wilson et al. 2004); hence both treatments are consistent with the available phylogenies. Another comprehensive molecular phylogeny of Lejeuneaceae (Wilson et al. 2007) resolved the monospecific genus Pluvianthus Schuster \& Schäfer-Verwimp in Schuster (1994: 213) and Harpalejeunea (Spruce 1884: 164) Schiffner (1893: 126) in a sister relationship to Lejeunea, however, this study lacked representatives of Microlejeunea. Pluvianthus resembles the "Lejeunea complex" (Lejeunea, Harpalejeunea and Microlejeunea) in many respects but differs by its utriculiform leaves, laminar elaters, and capsule microanatomy (Schuster \& Schäfer-Verwimp 1995). Harpalejeunea closely resembles Microlejeunea but has underleaves with diverging lobes, those of Microlejeunea being forward directed (Grolle \& Reiner-Drehwald 1999). The generic circumscription of Harpalejeunea is still subject to controversy. Grolle \& ReinerDrehwald (1995) separate Harpalejeunea by its lejeuneoid subgynoecial innovations from Drepanolejeunea Spruce (1884: 186) Schiffner (1893: 126) with pycnolejeuneoid innovations. In contrast, Schuster (1980) considered Harpalejeunea filicuspis (Stephani 1913b: 344) Mizutani (1973: 197) to be an element of Drepanolejeunea, despite the presence of lejeuneoid subgynoecial innovations.

In the present study we test the current genus concepts by including representatives of Harpalejeunea, Microlejeunea, and Pluvianthus in a three-marker dataset of Lejeuneeae. Based on the outcome of our phylogenetic analyses we accept the genera Microlejeunea and Harpalejeunea but transfer several representatives of Harpalejeunea and Pluvianthus to Microlejeunea. 


\section{Materials and methods}

Taxa studied, DNA extraction, PCR amplification and sequencing:-Plant tissue was isolated from herbarium collections of specimens assigned to the Lejeuneeae genera Drepanolejeunea, Harpalejeunea, Microlejeunea and Pluvianthus (Table 1). Total genomic DNA was purified using Invisorb Spin Plant Mini Kit (Invitek, Berlin, Germany) prior to amplification. Protocols for PCR were carried out as described in previous publications: chloroplast genome $r b c \mathrm{~L}$ gene and $t r n \mathrm{~L}-\mathrm{F}$ region from Gradstein et al. (2006), and nuclear ribosomal ITS1-5.8S-ITS-2 region from Hartmann et al. (2006). Bidirectional sequences were generated using a MegaBACE 1000 automated sequencing machine using DYEnamic ET Primer DNA Sequencing Reagent (Amersham Biosciences, Little Chalfont, UK). Sequencing primers were those used for PCR. Newly generated sequences were assembled and edited using SeqAssem (Hepperle 2004).

We compiled a Lejeuneeae ingroup dataset based on Wilson et al. (2007) using our new sequences as well as Genbank sequences (http://www.ncbi.nlm.nih.gov/genbank/). Thirteen representatives of Brachiolejeuneeae and Ptychanthoideae were chosen as outgroup according to the topologies presented in Wilson (2007). The related sequences came also from Genbank (Table 1).

Phylogenetic analyses:-All sequences were aligned manually in Bioedit version 7.0.5.2 (Hall 1999). Ambiguous positions were excluded from the alignments. Missing sequence stretches were coded as unknown. Maximum parsimony (MP) analyses were carried out with PAUP* version 4.0b10 (Swofford 2000). MP heuristic searches were conducted with the following options implemented: heuristic search mode, 1.000 random-addition-sequence replicates, tree bisection-reconnection (TBR) branch swapping, MULTrees option on, and collapse zero-length branches off. All characters were treated as equally weighted and unordered. Where more than one most parsimonious tree was found, trees were summarized in a strict consensus tree.

Non-parametric bootstrapping values (Felsenstein 1985) were generated as heuristic searches with 1.000 replicates, each with ten random-addition replicates. Rearrangements were restricted to $10,000,000$ per replicate. Bootstrap percentage 
values (BPV) $\geq 70$ were regarded as good support (Hillis and Bull 1983). The individual marker sets and the combined chloroplast DNA dataset vs nrITS dataset were first analysed separately to check for incongruence. The strict consensus trees of the nonparametric bootstrap analyses were compared by eye to identify conflicting nodes supported by at least 70\% (Mason-Gamer and Kellog 1996). The trees gave no evidence of incongruence. Hence the datasets were combined.

jModeltest 0.1 (Posada 2008) was used to select models of evolution for maximum likelihood (ML) analyses of the three molecular markers. A TVM $+\Gamma$ model for the $r b c L-$ partition and GTR $+I+\Gamma$ models for the trnL-F partition and the nrITS partition were implemented in the program GARLI version 2.0 (Zwickl, 2006). Subsequently the datasets were combined and $M L$ trees were generated. All GARLI analyses were performed with the default settings and several times repeated. The default setting of GARLI was also employed to calculate bootstrap values for ML analyses based on 200 bootstrap replicates.

Distribution of ocelli:-Ocelli are modified leaf cells containing only a single large oil body (Suire 1999). Their distribution was reconstructed using MP criteria as implemented in Mesquite ver. 2.72 (Maddison and Maddion, 2004) based on the ML topology. Data on the presence or absence of ocelli were obtained from the literature, in addition to our own observations.

\section{Results}

Of the 2,064 investigated sequence characters, 758 were parsimonious informative and 190 were unique to a single specimen (see Table 2 for character state distributions within the single markers). The MP analysis yielded five equally parsimonious trees with a length of 5,487 steps, a consistency index $(\mathrm{Cl})$ of 0.30 and a retention index (RI) of 0.66. The strict consensus is depicted in Figure 1. Representatives of Harpalejeunea, Lejeunea and Microlejeunea ("Lejeunea complex") formed a polytomous lineage with a BPV of 100. A Harpalejeunea clade with the species H. grandistipula Schuster (1999: 290), H. grandis Grolle \& Reiner-Drehwald (1999: 32), H. marginalis (Hooker \& Taylor 
1845: 91) Stephani (1913a: 271) and H. molleri (Stephani 1887: 3) Grolle (1989: 89) achieved a BPV of 100. Harpalejeunea filicuspis, H. fischeri (Tixier 1995: 29), H. latitans (Hooker \& Taylor 1844: 399) Grolle (1980: 239) and Pluvianthus squarrosus (Stephani 1896: 130) Schuster \& Schäfer-Verwimp in Schuster (1994: 213) were nested in a clade with several species of Microlejeunea including the generitype $M$. africana Stephani (1888: 61). This clade had a BPV of 95. Multiple accessions of Harpalejeunea filicuspis, H. fischeri, Drepanolejeunea anoplantha (Spruce 1884: 189) Stephani (1913b: 325), D. vandenberghenii Buchbender \& Fischer (2004: 273), D. vesiculosa (Mitten 1861: 116) Stephani (1913b: 356) and Pluvianthus squarrosus formed monophyletic lineages. Representatives of Microlejeunea africana from Principe Island and Madagascar were placed in separate clades. Drepanolejeunea was monophyletic with a BPV of 56 . It consisted of two main lineages, each with a BPV of 100. Drepanolejeunea was placed in a clade with Cololejeunea (Spruce 1884: 291) Schiffner (1893: 121), Colura (Dumortier 1831: 32) Dumortier (1835: 12), Diplasiolejeunea (Spruce 1884: 301) Schiffner (1893: 121), Macrocolura Schuster (1994: 233), Myriocoleopsis Schiffner (1944: 234), and Siphonolejeunea Herzog in Skottsberg (1942: 744).

The ML tree (Figure 2, In $=-29005,9392$ ) resembled the MP strict consensus tree. The Harpalejeunea clade was placed sister to the clade with Microlejeunea, Pluvianthus and several Harpalejeunea species. This sister relationship had a BPV of 66. The Cololejeunea-Colura-Diplasiolejeunea-Drepanolejeunea-Macrocolura-Myriocoleopsis-

Siphonolejeunea clade achieved a BPV of 83. In our reconstruction ocelli evolved twice in Lejeuneeae and were lost twice in the main "ocelli clade" with a BPV of 99. MP character reconstruction suggested the occurrence of ocelli as a putative apomorphy of derived Lejeuneeae and a loss of this character in the clade comprising Lejeunea s.str.

\section{Discussion and taxonomic treatment}

Circumscription of genera:- Arguably the Lejeunea complex belongs to the most difficult groups of liverworts in terms of genus circumscription. As a consequence of Spruce's (1884) wide genus concept, numerous heterogeneous elements were placed in Lejeunea, and classified into 39 subgenera (Spruce 1884). Most of these subgenera were elevated to genus rank by Schiffner (1893). Later authors established additional 
genera that often included only one or a few species, e.g., Amblyolejeunea Jovet-Ast (1948: 24), Bromeliophila Schuster (1994: 226), Dactylolejeunea Schuster (1971: 341), and Metalejeunea Grolle (1995: 17). Many of these genera were shown to nest within larger genera, and were treated as synonyms (Wilson et al. 2007, Ye \& Zhu 2010, Heinrichs et al. 2012b). Recently, a considerable number of these genera were transferred to Lejeunea (Heinrichs et al. 2012a). These changes resulted in a rather heteromorphic genus Lejeunea including species with different size, leaf and underleaf shape, and different perianth forms (e.g., Reiner-Drehwald \& Goda 2000, Ilkiu-Borges 2005, Reiner-Drehwald 2005, Reiner-Drehwald \& Schäfer-Verwimp 2008). With a single exception, these species lack ocelli (Reiner-Drehwald \& Ilkiu-Borges 2007). In contrast, the Harpalejeunea-Microlejeunea-Pluvianthus clade consistently possesses ocelli (Grolle 1995, Schuster \& Schäfer-Verwimp 1995, Grolle \& Reiner-Drehwald 1999). Harpalejeunea is characterized by leaves with basal or suprabasal ocelli, diverging underleaf lobes with blunt, obtuse to rounded apices, and lejeuneoid gynoecial innovations. We already sequenced about 60 accessions of Harpalejeunea which fall into the Harpalejeunea clade of Figures 1 and 2, however, as a consequence of the unclear species taxonomy (Grolle \& Reiner-Drehwald 1999) we included only a few of our Harpalejeunea accessions in the present study. Species delimitation and phylogeny of Harpalejeunea will be addressed in separate studies.

A few Harpalejeunea species, namely $H$. filicuspis, $H$. fischeri, and $H$. latitans were resolved in a clade with several species of Microlejeunea including the generitype $M$. africana. These species lack the typical Harpalejeunea underleaves; instead they possess underleaves with forward directed lobes (e.g., Mizutani 1973, Figure IV: 12-13; Grolle 1980, Figure 2: f-i; Buchbender \& Fischer 2004, Figures 6 and 7). Microlejeunea resembles Harpalejeunea in many aspects but has the above type of underleaves (Grolle \& Reiner-Drehwald 1999). Hence a transfer of the above three species of Harpalejeunea to Microlejeunea is justified both by molecular and morphological data, and formalized below. Already Schuster (1980: 1177) doubted the systematic position of $H$. filicuspis and considered a placement in Drepanolejeunea, as was first proposed by Stephani (1913b: 344). Drepanolejeunea, however, has pycnolejeuneoid innovations, not the lejeuneoid ones of the Lejeunea complex (Mizutani 1973, Grolle 1980). The 
difficulties in separating Harpalejeunea filicuspis from Drepanolejeunea were also evident in our DNA vouchers. All four Indonesian Drepanolejeunea vesiculosa accessions were initially identified as Harpalejeunea filicuspis.

Pluvianthus forms a derived clade within the Microlejeunea lineage. This genus shares with Microlejeunea the shape of the underleaves, the presence of three medullary cells and the tendency to produce ocelli (Schuster \& Schäfer-Verwimp 1995). Otherwise it is quite different; its sole species $P$. squarrosus differs from other representatives of the Microlejeunea clade (Figures 1,2) by its larger size and robust habit, and larger leaf lobes (see Schuster \& Schäfer-Verwimp 1995 for a detailed morphological treatment). However, we support monophyletic genus concepts (Humphreys \& Linder 2009) and treat Pluvianthus as a synonym of Microlejeunea.

\section{Key for identification of the genera of the Lejeunea complex}

1. Plants lacking ocelli..............................................................................ejeunea

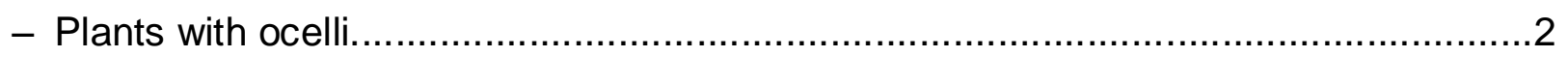

2. Underleaves ovate, with forward-directed, blunt to acute lobes separated by a narrow sinus Microlejeunea

- Underleaves obtrapezoid, with diverging, blunt (obtuse to rounded) lobes separated by a wide sinus. Harpalejeunea *the sole representative of the genus with ocelli, Lejeunea huctumalcensis Lindenberg \& Gottsche in Gottsche et al. (1847: 762) has not yet been included in a molecular phylogenetic study.

Although our treatment leads to a morphologically somewhat unstable Microlejeunea concept, the genus can be separated from other genera of the Lejeunea complex by the shape of the underleaves and the presence of ocelli, which, however, are best seen in living or freshly collected material. At first glance, the new circumscription may be somewhat irritating, however, numerous genera of liverworts show an even broader morphological variation, e.g., Chiloscyphus Corda (1829: 651), Lejeunea, Leptoscyphus Mitten (1851: 358), Frullania Raddi (1818: 9) or Plagiochila (Dumortier 1831: 42) Dumortier (1835: 14). Our study supports a general trend towards broader genus concepts in Lejeuneaceae (Heinrichs et al. 2012a, b), which still belong to the poorly 
studied liverwort families in terms of molecular investigation. Follow-up studies with a denser taxon sampling are needed to scrutinize the new genus concepts.

Distribution of ocelli:-Ocelli are widespread in Lejeuneaceae and occur also in Frullaniaceae (Gradstein et al. 2003). According to our reconstruction (Figure 2), ocelli evolved twice in Lejeuneeae. However, the position of Pycnolejeunea (Spruce 1884: 246) Schiffner (1893: 124) is unsecured and lacks bootstrap support. Ocelli were lost twice in the main "ocelli-clade". The pattern will likely be somewhat more complex when ocellate Cheilolejeunea (Spruce 1884: 251) Schiffner (1893: 124) (Bastos 2012) and Cololejeunea species (Zhu \& So 1999) will be included in the dataset.

The presence or absence of ocelli allows for a recognition of two main clades of the "Lejeunea complex", Lejeunea (without ocelli) and Microlejeunea plus Harpalejeunea (with ocelli). He \& Piippo (1999) and Gradstein et al. (2003) distinguished different types of ocelli based on their distribution in leaves and underleaves and their arrangement; those of Harpalejeunea are colorless and form a short row near the leaf base (Gradstein et al. 2001). The 1-3(-6) ocelli of Microlejeunea are usually positioned near the leaf base. Pluvianthus (Microlejeunea) squarrosus includes highland forms with leaves with 0-2(4) basal ocelli and forms from lower elevations having up to 16 ocelli in 2-3 rows at the leaf bases, in addition to up to 70 ocelli in the perianth (Schuster \& Schäfer-Verwimp 1995). A larger sampling is necessary to evaluate whether the distribution of ocelli in Pluvianthus squarrosus is correlated with molecular variation.

\section{Species classification and extensions of range:-Multiple accessions of} Pluvianthus squarrosus and several Drepanolejeunea species form robust monophyletic lineages, indicating congruence of molecular and morphological species concepts (Figs 1, 2). Our study also provides evidence for a larger African range of Drepanolejeunea vandenberghenii, a recently described species that is so far known only from Rwanda (Buchbender \& Fischer 2004). Several accessions from Madagascar, Malawi and Réunion formed a monophyletic lineage with a $D$. vandenberghenii paratype from Rwanda, and were also in good accordance with the detailed morphological description of Buchbender \& Fischer (2004). 
Buchbender \& Fischer (2004) already pointed to morphological similarities of $D$. vandenberghenii and $D$. vesiculosa. This observation is confirmed in our study where both species form a robust sister relationship. In the present study we adopt a wide species concept for $D$. vesiculosa [incl. D. physaefolia (Gottsche 1882: 357) Stephani (1913b: 324); Tixier (1995)]; however, the considerable sequence variation within the $D$. vesiculosaclade may indicate that several independent biological entities are at hand.

In contrast to the situation in Drepanolejeunea, not all morphologically circumscribed Microlejeuneaspecies were consistent with the relationships supported by the genotypic evidence. The Microlejeunea africana specimens from Principe Island-the type locality-and an accession from Madagascar formed independent lineages although they were morphologically very similar. The Microlejeunea sp. accession from Thailand was originally identified as M. ulicina (Taylor 1844: 115) Stephani (1890: 88), however, M. ulicina accessions from the Canary Islands were only loosely related to this accession. Morphologically cryptic or nearly cryptic speciation is a common phenomenon in liverworts (e.g., Odrzykoski \& Szweykowski 1991, Wachowiak et al. 2009, Feldberg et al. 2010, Heinrichs et al. 2010, 2011, Kreier et al. 2010, Renner et al. 2011, Dong et al. 2012) and not unexpected in the morphogically strongly reduced genus Microlejeunea. A much denser sampling is required to arrive at a more natural classification of the genus, however, only few specimens are available which are suitable for molecular investigation. Microlejeunea species often grow intermingled with other bryophytes, and often only in very small cushions. On the other hand it would be worthwile to investigate intercontinentally distributed taxa such as M. ulicina for the presence of geographical clades and other morphologically cryptic lineages. It needs to be stressed that $M$. africana has already been treated as a subspecies of $M$. ulicina based on a broad morphological overlap (Vanden Berghen 1972). Grolle (1995) pointed out that the distinction between the two taxa is merely based on geographical patterns and needs clarification; however, the uniform morphology belies a considerable molecular variation. 


\section{Taxonomic treatment}

Microlejeunea Stephani (1888: 61)

= Pluvianthus Schuster \& Schäfer-Verwimp in Schuster (1994: 213), syn. nov.

Microlejeunea squarrosa (Steph.) Heinrichs, Schäf.-Verw., Pócs \& S. Dong, comb. nov. Basionym: Strepsilejeunea squarrosa Steph., Hedwigia 35: 130, 1896.

= Pluvianthus squarrosus (Steph.) R.M. Schust. \& Schäf-Verw., J. Hattori Bot. Lab. 75: 213, 1994.

Microlejeunea filicuspis (Steph.) Heinrichs, Schäf.-Verw., Pócs \& S. Dong, comb. nov. Basionym: Drepanolejeunea filicuspis Steph., Spec. Hepat. V: 344, 1913.

= Harpalejeunea filicuspis (Steph.) Mizut., J. Hattori Bot. Lab. 37: 197, 1973.

Microlejeunea fischeri (Tixier) Heinrichs, Schäf.-Verw., Pócs \& S. Dong, comb. nov. Basionym: Harpalejeunea fischeri Tixier, Trop. Bryol. 11: 29, 1995.

Microlejeunea latitans (Hook. f. \& Taylor) Heinrichs, Schäf.-Verw., Pócs \& S. Dong, comb. nov.

Basionym: Jungermannia latitans Hook. f. \& Taylor, London J. Bot. 3: 399, 1844.

$=$ Lejeunea latitans (Hook. f. \& Taylor) Gottsche, Lindenb. \& Nees, Syn. Hepat. 345, 1845

= Drepanolejeunea latitans (Hook. f. \& Taylor) Steph., Hedwigia 29: 72, 1890.

= Harpalejeunea latitans (Hook. f. \& Taylor) Grolle, J. Hattori Bot. Lab. 47: 239, 1980.

\section{Perspectives}

Our study is a step forward towards a monophyletic genus concept for the Lejeunea complex. However, several putatively related genera such as Bromeliophila and Metalejeunea need to be included in follow-up studies. Our previous attempts to extract DNA from herbarium specimens of these genera were not successful but fresh material may allow to produce sequences of these taxa. 


\section{Acknowledgements}

This study was supported by the Deutsche Forschungsgemeinschaft [HE 3584/2 and 4, LE 1825/4]. SD was supported by the China Scholarship Council (scholarship No. 2010697001). HS acknowledges the Senior Visiting Professorship awarded by the Chinese Academy of Sciences. We acknowledge useful comments of Matt Renner (Sidney, Australia). This is publication number 106 from the Courant Research Centre Geobiology that is funded by the German Initiative of Excellence.

\section{References}

Ah-Peng, C. \& Bardat, J. (2011) Microlejeunea strasbergii sp. nov. (Lejeuneaceae) from Réunion Island (Mascarenes). The Bryologist 114: 668-673.

Ahonen, I., Muona, J. \& Piippo, S. (2003) Inferring the phylogeny of the Lejeuneaceae (Jungermanniopsida): a first appraisal of molecular data. The Bryologist 106: 297-308.

Bastos, C.J.P. (2012) Taxonomy and distribution of Cheilolejeunea aneogyna (Spruce) A. Evans (Lejeuneaceae, Marchantiophyta). Acta Botanica Brasilica 26: 709-713.

Bischler, H., Bonner, C.E.B. \& Miller, H.A. (1963) Studies in Lejeuneaceae, VI. The genus Microlejeunea Steph. in Central and South America. Nova Hedwigia 5: 359411.

Bischler, H., Miller, H.E. \& Bonner, C.E.B. (1962) Studies in Lejeuneaceae IV: The typification of the genus Microlejeunea. Nova Hedwigia 4: 173-187.

Buchbender, V. \& Fischer, E. (2004) Drepanolejeunea vandenberghenii (Jungermanniopsida: Lejeuneaceae), a previously overlooked new species from Rwanda including comments on D. physaefolia and Harpalejeunea fischeri. Journal of Bryology 26: 273-283.

Corda, A.J.C. (1829) Genera Hepaticarum. Die Gattungen der Lebermoose. In: Opiz, P.M. (ed.), Naturalientausch 12, pp. Prague, Enders, pp. 643-655. 
Dong, S.S., Schäfer-Verwimp, A., Meinecke, P., Feldberg, K., Bombosch, A., Pócs, T., Schmidt, A.R., Reitner, J., Schneider, H. \& Heinrichs, J. (2012) Tramps, narrow endemics and morphologically cryptic species in the epiphyllous liverwort Diplasiolejeunea. Molecular Phylogenetics and Evolution 65: 582-594.

Dumortier, B.C.J. (1831) Sylloge Jungermannidearum Europae indigenarum: earum genera et species systematice complectens. Casterman, Tournay, $100 \mathrm{pp}$.

Dumortier, B.C.J. (1835) Recueil d'Observations sur les Jungermanniacées. Blanquart, Tournay, $27 \mathrm{pp}$.

Feldberg, J., Váňa, J., Long, D.G., Shaw, J., Hentschel, J., Heinrichs, J. (2010) A phylogeny of Adelanthaceae (Jungermanniales, Marchantiophyta) based on nuclear and chloroplast DNA markers, with comments on classification, cryptic speciation and biogeography. Molecular Phylogenetics and Evolution 55: 293-304.

Felsenstein, J. (1985) Confidence limits on phylogenies: an approach using the bootstrap. Evolution 39: 783-791.

Gottsche, C.M. (1882) Reliquiae Rutenbergianae. Lebermoose. Abhandlungen herausgegeben vom Naturwissenschaftlichen Verein zu Bremen 7: 338-365.

Gottsche, C.M., Lindenberg, J.B.G. \& Nees ab Esenbeck, C.G. (1844-1847) Synopsis Hepaticarum. Hamburg, Meissner, 834 pp.

Gradstein, S.R., Churchill, S.P. \& Salazar-Allen, N. (2001) Guide to the bryophytes of tropical America. Memoirs of the New York Botanical Garden 86: 1-577.

Gradstein, S.R. \& Pinheiro da Costa, D. (2003) The Hepaticae and Anthocerotae of Brazil. Memoirs of the New York Botanical Garden 87: I-XVIII, 1-318.

Gradstein, S.R., Reiner-Drehwald, M.E. \& Jost, L. (2004) The systematic position and distribution of Myriocolea irrorata (Lejeuneaceae), an endangered liverwort of the Ecuadorian Andes. Journal of the Hattori Botanical Laboratory 95: 235-248. 
Gradstein, S.R., Reiner-Drehwald, M.E. \& Schneider, H. (2003) A phylogenetic analysis of the genera of Lejeuneaceae (Hepaticae). Botanical Journal of the Linnean Society 143: 391-410.

Gradstein, S.R., Wilson, R., Ilkiu-Borges, A.L. \& Heinrichs, J. (2006) Phylogenetic relationships and neotenic evolution of Metzgeriopsis (Lejeuneaceae) based on chloroplast DNA sequences and morphology. Botanical Journal of the Linnean Society 151: 293-308.

Grolle, R. (1980) Über Harpalejeunea in Australasien. Journal of the Hattori Botanical Laboratory 47: 237-244.Grolle, R. (1989) A technically new lectotypification of Harpalejeunea (Hepaticae). Taxon 38: 88-90.

Grolle, R. (1995) The Hepaticae and Anthocerotae of the East African Islands. Bryophythorum Bibliotheca 48: 1-178.

Grolle, R. \& Reiner-Drehwald, M.E. (1999) Review of the genus Harpalejeunea (Lejeuneaceae) including the description of $H$. grandis, a new species from the páramos of Colombia. Journal of Bryology 21: 31-45.

Hall, T.A. (1999) BIOEDIT: a user-friendly biological sequence alignment editor and analysis program for Windows 95/98/NT. Nucleic Acids Symposia Series 41: 95-98.

Hartmann, F.A., Wilson, R., Gradstein, S.R., Schneider, H. \& Heinrichs, J. (2006) Testing hypotheses on species delimitations and disjunctions in the liverwort Bryopteris (Jungermanniopsida: Lejeuneaceae). International Journal of Plant Sciences 167: 1205-1214.

He, X.L. \& Piippo, S. (1999) On the taxonomic significance of ocelli characters in the hepatic family Lejeuneaceae. Bryobrothera 5: 93-97.

Heinrichs, J., Dong, S., Feldberg, K., Schäfer-Verwimp, A. \& Schmidt, A.R. (2012a) Sphaerolejeunea (Lejeuneaceae, Porellales) is a synonym of Lejeunea. Phytotaxa 69: 7-15. 
Heinrichs, J., Dong, S., Yu, Y., Schäfer-Verwimp, A., Pócs, T., Feldberg, K., Hentschel, J., Schmidt, A.R. \& Schneider, H. (2012b) A 150 year old mystery solved: Transfer of the rheophytic liverwort Myriocolea irrorata to Colura. Phytotaxa 66: 55-64.

Heinrichs, J., Hentschel, J., Bombosch, A., Fiebig, A., Reise, J., Edelmann, M., Kreier, H.-P., Schäfer-Verwimp, A., Caspari, S., Schmidt, A.R., Zhu, R.-L., von Konrat, M., Shaw, B. \& Shaw, A.J. (2010) One species or at least eight? Delimitation and distribution of Frullania tamarisci (L.) Dumort. (Jungermanniopsida, Porellales) inferred from nuclear and chloroplast DNA markers. Molecular Phylogenetics and Evolution 56: 1105-1114.

Heinrichs, J., Kreier, H.-P., Feldberg, K., Schmidt, A.R., Zhu, R.L., Shaw, B., Shaw, A.J., Wissemann, V. (2011) Formalizing morphologically cryptic biological entities: New insights from DNA taxonomy, hybridization, and biogeography in the leafy liverwort Porella platyphylla (Jungermanniopsida, Porellales). American Journal of Botany 98: 1252-1262.

Hepperle, D. (2004) SeqAssem@. A sequence analysis tool, contig assembler and trace data visualization tool for molecular sequences. Win32-Version. Distributed by the author via: http://www.sequentix.de.

Herzog, T. (1938) Sphaerolejeunea, eine neue Gattung der Lejeuneaceae Schizostipae. Annales Bryologici 11: 86-89.

Hillis, D.M. \& Bull J.J. (1993) An empirical test of bootstrapping as a method for assessing the confidence in phylogenetic analysis. Systematic Biology 42: 182-192.

Hooker, J.D. \& Taylor, T.T. (1844) Hepaticae Antarcticae; being characters and brief descriptions of the Hepaticae discovered in the southern circumpolar regions during the voyage of H. M. discovery ships Erebus and Terror. London Journal of Botany 3: 366-400.

Hooker, J.D. \& Taylor, T.T. (1845) Hepaticae Antarcticae, supplementum: or specific characters, with brief descriptions, of some additional species of the Hepaticae of the 
Antarctic regions, New Zealand and Tasmania, together with a few from the Atlantic islands and New Holland. London Journal of Botany 4: 79-97.

Humphreys, A.M. \& Linder, H.P. (2009) Concept versus data in delimitation of plant genera. Taxon 58: 1054-1074.llkiu-Borges, A.L. (2005) A taxonomic revision of Echinocolea. Nova Hedwigia 80: 45-71.

Jovet-Ast, S. (1948) Hépatiques des Antilles françaises récoltées par P. et V. Allorge en 1936. Revue Bryologique et Lichénologique 17: 24-34.

Konstantinova, N.A. \& Vilnet, A.A. (2011) Jubula hutchinsiae ssp. caucasica subsp. nov. (Jubulaceae, Marchantiophyta) - a new taxon from the Western Caucasus. Arctoa 20: 227-238.

Kreier, H.-P., Feldberg, K., Mahr, F., Bombosch, A., Schmidt, A.R., Zhu, R.-L., von Konrat, M., Shaw, B., Shaw, A.J., Heinrichs, J. (2010) Phylogeny of the leafy liverwort Ptilidium: cryptic speciation and shared haplotypes between the Northern and Southern Hemispheres. Molecular Phylogenetics and Evolution 57: 1260-1267.

Libert, M. (1820) Sur un genre noveau d'Hépatiques, Lejeunia. Annales Generales des Sciences Physiques 6: 372-374.Maddison, D.R. \& Maddison, W.P. (2004) Mesquite, version 2. Tucson, Arizona. Available at http://mesquiteproject.org

Mason-Gamer, R.J. \& Kellogg, E.A. (1996) Testing for phylogenetic conflict among molecular data sets in the tribe Triticeae (Gramineae). Systematic Biology 45: 524545.

Mitten, W. (1851) Catalogue of cryptogamic plants collected by Professor W. Jameson in the vicinity of Quito. Hooker's Journal of Botany and Kew Garden Miscellany 3: 351-362.

Mitten, W. (1861) Hepaticae Indiae Orientalis: an ennumeration of the Hepaticae of the East Indies. Journal of the Proceedings of the Linnean Society, Botany 5: 89-128. 
Mizutani, M. (1973) The genus Harpalejeunea from Sabah (North Borneo). Journal of the Hattori Botanical Laboratory37: 191-203.

Odrzykoski, I.J. \& Szweykowski, J. (1991) Genetic differentiation without concordant morphological divergence in the thallose liverwort Conocephalum conicum. Plant Systematics and Evolution 178: 135-152.

Raddi, G. (1818) Jungermanniografia Etrusca. Memorie i Mathematica e di Fisica della Societa Italiana delle Scienze (Modena) 18: 14-56.

Reiner-Drehwald, M.E. (1999) Catalogue of the genus Lejeunea Lib. (Hepaticae) of Latin America. Bryophytorum Bibliotheca 54: 1-101.Reiner-Drehwald, M.E. (2005b) On Lejeunea rotundifolia and Dicladolejeunea (Lejeuneaceae, Jungermanniopsida). Systematic Botany 30: 687-692.

Reiner-Drehwald, M.E. \& Goda, A. (2000) Revision of the genus Crossotolejeunea (Lejeuneaceae, Hepaticae). Journal of the Hattori Botanical Laboratory 89: 154.Reiner-Drehwald, M.E. \& Ilkiu-Borges, A.L. (2007) Lejeunea huctumalcensis, a widely distributed Lejeuneaceae from the Neotropics, and its relation to Ceratolejeunea. The Bryologist 110: 465-474.

Reiner-Drehwald, M.E. \& Schäfer-Verwimp, A. (2008) On Inflatolejeunea, Lejeunea species with eplicate perianths and Lejeunea talamancensis sp. nov. from Costa Rica. Nova Hedwigia 87: 387-420.

Renner, M.A.M., Brown E.A. \& Wardle, G.M. (2011) The Lejeunea tumida group is positively polyphyletic. Australian Systematic Botany 24: 10-18.

Schiffner, V. (1893) Hepaticae. In: Engler, A. \& Prantl, K., Die natürlichen Pflanzenfamilien 1. Engelmann, Leipzig, pp. 97-141.

Schiffner, V. (1944) Myriocoleopsis, eine neue Gattung der Jubuleae. Hedwigia 81: 234237. 
Schuster, R.M. (1957) North American Lejeuneaceae VI. Lejeunea: Introduction and keys; subgenus Lejeunea I. Journal of the Elisha Mitchel Scientific Society 73: 122197.

Schuster, R.M. (1971) Studies on Hepaticae, XLIX-LIII. New Lejeuneaceae from Dominica and Jamaica. Bulletin of the Torrey Botanical Club 97: 336-352.

Schuster, R.M. (1980) The Hepaticae and Anthocerotae of North America. Volume 4. New York, Columbia University Press, 1344 pp.

Schuster, R.M. (1994) Studies on Lejeuneaceae, I. Preliminary studies on new genera and subgenera of Lejeuneaceae. Journal of the Hattori Botanical Laboratory 75: 211235.

Schuster, R.M. (1999) Harpalejeunea (Spr.) Schiffn. I: Studies on a new Andean species of Harpalejeunea. Journal of the Hattori Botanical Laboratory 87: 287-294.

Schuster, R.M. \& Schäfer-Verwimp, A. (1995) On Pluvianthus (Lejeuneaceae: Lejeuneoideae). Nova Hedwigia 60: 59-72.Skottsberg, C.J.F. (1942) The Natural History of Juan Fernandez and Easter Island 2. Botany. Almqvist \& Wiksells, Uppsala, $744 \mathrm{pp}$.

Spruce, R.M. (1884) Hepaticae Amazonicae et Andinae. Tribus I: Jubuleae. Transactions and Proceedings of the Botanical Society of Edinburgh 15: 1-308.

Stephani, F. (1887) Über einige Lebermoose Portugals. Hedwigia 26: 1-6.Stephani, F. (1888) Hepaticae Africanae. Hedwigia 27: 59-63.

Stephani, F. (1890) Die Gattung Lejeunea im Herbarium Lindenberg (Fortsetzung). Hedwigia 29: 68-99.

Stephani, F. (1896) Hepaticarum species novae IX. Hedwigia 35: 73-140.

Stephani, F. (1913a) Harpalejeunea. Species Hepaticarum V, Georg \& Cie, Geneva, pp. 243-273. 
Stephani, F. (1913b) Drepanolejeunea. Species Hepaticarum V, Georg \& Cie, Geneva, pp. 317-360.

Suire, C. (1999) A comparative, transmission-electron microscopic study on the formation of oil-bodies in liverworts. Journal of the Hattori Botanical Laboratory 89: 209-232.

Swofford, D.L. (2000) PAUP*, phylogenetic analyses using parsimony ( ${ }^{*}$ and other methods), version 4.01b10.

Sinauer Associates, Sunderland, Massachusetts.Taylor, T. (1844) Descriptions of Jungermannia ulicina, (Taylor), and of J. lyoni, (Taylor). Transactions and Proceedings of the Botanical Society of Edinburgh 1: 115-118.

Thiers, B.M. (1997) Lejeunea bischlerae, a new species of Lejeunea subgenus Microlejeunea from Australia. Cryptogamie, Bryologie et Lichénologie 18: 223-226.

Tixier, P. (1995) Résultats taxonomiques de l'éxpédition BRYOTROP au Zaire et Rwanda. 30. Bryophytes épiphylles (récoltes de E. Fischer). Tropical Bryology 11: 1176.

Vanden Berghen, C. (1972) Hépatiques et Anthocérotées. In : Symoens, J.J. (ed.), Résultats schientifiques. Exploration hydrobiologique du bassin du lac Bangweolo et du Luapula 8: 1-220.

Wachowiak, W., Bącziewicz, A., Chudzińska, E. \& Buczkowska, K. (2007) Cryptic speciation in liverworts - a case study in the Aneura pinguis complex. Botanical Journal of the Linnean Society 155: 273-282.

Wilson, R., Gradstein, S.R., Heinrichs, J., Groth, H., Ilkiu-Borges, A.L. \& Hartmann, F.A. (2004) Phylogeny of Lejeuneaceae: a cladistic analysis of chloroplast gene rbcL sequences and morphology, with preliminary comments on the mitochondrial NAD4-2 spacer region. Monographs in Systematic Botany from the Missouri Botanical Garden98: 189-202. 
Wilson, R., Gradstein, S.R., Schneider, H. \& Heinrichs, J. (2007) Unravelling the phylogeny of Lejeuneaceae (Jungermanniopsida): evidence for four main lineages. Molecular Phylogenetics and Evolution 43: 270-282.

Ye, W. \& Zhu, R.L. (2010) Leucolejeunea, a new synonym of Cheilolejeunea (Lejeuneaceae), with special reference to new combinations and nomenclature. Journal of Bryology 32: 279-282.

Zhu, R.L. \& So, M.L. (1999) New records of Cololejeunea for China and Vietnam. Botanical Bulletin of Academia Sinica 40: 165-171.

Zwickl, D.J. (2006) Genetic algorithm approaches for the phylogenetic analysis of large biological sequence datasets under the maximum likelihood criterion. GARLI version 2.0 available online at https://code.google.com/p/garli/. 
TABLE 1. Taxa used in the present study, including information about the origin of the studied material, voucher information, as well as GenBank accession numbers. New sequences in bold face.

Taxon Voucher

$$
r b c \mathrm{~L} \quad \mathrm{trnL}-\mathrm{F} \quad \mathrm{nrITS}
$$

$\begin{array}{lllll}\text { Acanthocoleus } & \text { Bali, Schäfer-Verwimp \& } & \text { DQ983648 } & \text { DQ987398 } & \text { DQ987291 } \\ \text { javanicus (Steph.) Kruijt } & \text { Verwimp 20817 (GOET) } & & & \end{array}$

Acrolejeunea fertilis $\quad$ Bali, Schäfer-Verwimp \& AY684929 DQ987391 DQ987281

(Reinw. et al.) Schiffn. Verwimp 17009(GOET)

Anoplolejeunea conferta Ecuador, Wilson et al. 04- DQ983653 DQ987438 DQ987335 (C.F.W. Meissn. ex 08 (GOET)

Spreng.) A.Evans

$\begin{array}{lllll}\text { Archilejeunea } & \text { Costa Rica, Bernecker 97 } & \text { DQ983655 } & \text { DQ987384 DQ987267 }\end{array}$

fuscescens (Hampe ex - 53 (GOET)

Lehm.) Fulf.

Aureolejeunea aurifera Costa Rica, Holz CR00- AY548082 DQ238569 DQ987272

R.M.Schust. 696 (GOET)

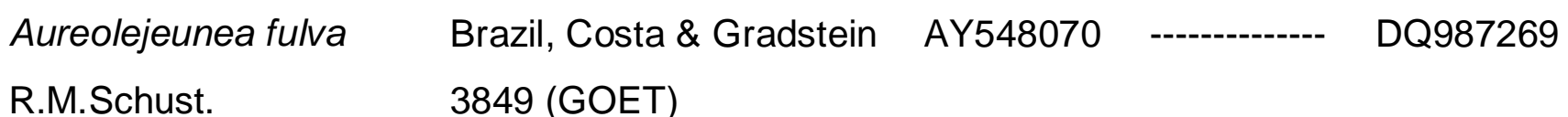

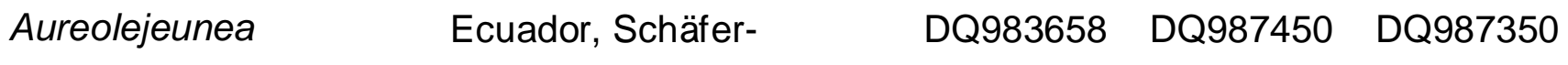

quinquecarinata Verwimp \& Preußing

R.M.Schust. 23299/A (GOET)

Bryopteris diffusa (Sw.) Bolivia, Acebey \&

AY548085 AM237147 AM237095

Nees

Villavicencio 855 (GOET) 
Ceratolejeunea cornuta (Lindenb.) Steph.

Ceratolejeunea cf. guianensis (Nees \& Mont.) Steph.

Cheilolejeunea acutangula (Nees)

Grolle

Cheilolejeunea beyrichi

(Lindenb.) E.Reiner

Cheilolejeunea clypeata (Schwein.) W. Ye \& R.L.

Zhu

Cheilolejeunea revoluta (Herz.) Gradst. \& Grolle

Cheilolejeunea rigidula (Mont.) R.M.Schust.

Cheilolejeunea xanthocarpa (Lehm. \& Lindenb.) Malombe

Cololejeunea laevigata

(Mitt.) Tilden

Cololejeunea

metzgeriopsis

(K.I.Goebel) Gradst. et.

al.

Cololejeunea obliqua

Ecuador, Wilson et al.

DQ983669

DQ987470 DQ987371

Brazil, Costa
3839 (GOET)

New Zealand, von Konrat

\& Herangi $503(F)$

Malaysia, Gradstein et al.

DQ238567 10436 (GOET)

AY548088 DQ238570 DQ987257

DQ983664 DQ987386 DQ987270

AY548091 DQ987387 DQ987271

DQ983699 DQ987426 DQ987322

DQ983668 DQ987453 DQ987353

DQ238563 DQ238571 DQ987349

DQ242521 DQ987319 (Nees \& Mont.) Schiffn. $\quad$ 04/11 (GOET) 


\begin{tabular}{|c|c|c|c|c|}
\hline $\begin{array}{l}\text { Cololejeunea peculiaris } \\
\text { (Herz.) Benedix }\end{array}$ & $\begin{array}{l}\text { Malaysia, Schäfer- } \\
\text { Verwimp \& Verwimp } \\
\text { 18861/A (GOET) }\end{array}$ & AY548095 & DQ238572 & DQ987280 \\
\hline $\begin{array}{l}\text { Cololejeunea vitalana } \\
\text { Tixier }\end{array}$ & $\begin{array}{l}\text { Costa Rica, Schäfer- } \\
\text { Verwimp \& Holz SV/H- } \\
\text { 0473/A (GOET) }\end{array}$ & DQ238564 & DQ238573 & DQ987348 \\
\hline $\begin{array}{l}\text { Colura acroloba (Mont. } \\
\text { ex. Steph.) Ast }\end{array}$ & $\begin{array}{l}\text { Fiji, Pócs 03261/BK } \\
\text { (GOET) }\end{array}$ & DQ238565 & DQ238586 & DQ987306 \\
\hline Colura cylindrica Herzog & $\begin{array}{l}\text { Guadeloupe, Schäfer- } \\
\text { Verwimp \& Verwimp } \\
\text { 22154/B (JE) }\end{array}$ & JX470969 & JX470980 & JX470992 \\
\hline
\end{tabular}

Colura irrorata (Spruce) $\quad$ Ecuador, Gradstein et al. AY548073 DQ238584 DQ987279 Heinrichs, Y. Yu, Schäf.- 10033 (GOET)

Verw. \& Pócs

Colura ornithocephala

Ecuador, Schäfer-

JX470974 JX470985 JX470997

Herzog

Verwimp \& Nebel 32854

(JE)

Colura tenuicornis A. Dominican Republic, $\quad$ JX470967 JX470978 JX470990 Evans) Steph. Schäfer-Verwimp \& Verwimp 27039 (JE)

Cyclolejeunea peruviana Colombia, Gradstein 8546 DQ983672 DQ987383 DQ987265 (Lehm. \& Lindenb.) A. (GOET)

Evans

$\begin{array}{lllll}\text { Diplasiolejeunea } & \text { Malaysia, Schäfer- } & \text { JQ729531 } & \text { JQ729641 } & \text { JQ729418 } \\ \text { cavifolia Steph. } & \text { Verwimp \& Verwimp } & & & \\ & \text { 19036/A (GOET) } & & & \\ & \text { Panama, De Gracia et al. } & \text { JQ729541 } & \text { JQ729652 } & \text { JQ729429 } \\ \begin{array}{l}\text { Diplasiolejeunea } \\ \text { pauckertii Steph. }\end{array} & 338 \text { (GOET) } & & & \end{array}$ 


\begin{tabular}{|c|c|c|c|c|}
\hline $\begin{array}{l}\text { Diplasiolejeunea pelluci } \\
\text { da (C.F.W. Meissn. ex } \\
\text { Spreng.) Schiffner }\end{array}$ & $\begin{array}{l}\text { Ecuador, Schäfer- } \\
\text { Verwimp et al. } 24134 \\
\text { (GOET) }\end{array}$ & JQ729500 & JQ729607 & JQ729383 \\
\hline $\begin{array}{l}\text { Diplasiolejeunea } \\
\text { unidentata (Lehm. \& }\end{array}$ & $\begin{array}{l}\text { Guadeloupe, Schäfer- } \\
\text { Verwimp \& Verwimp }\end{array}$ & JQ729481 & JQ729588 & JQ729365 \\
\hline Lindenb.) Steph. & 22500/A (GOET) & & & \\
\hline $\begin{array}{l}\text { Drepanolejeunea } \\
\text { anoplantha (Spruce) }\end{array}$ & $\begin{array}{l}\text { Dominican Republic, } \\
\text { Schäfer-Verwimp \& }\end{array}$ & KC313120 & KC313159 & KC313080 \\
\hline Steph. & Verwimp 27059 (JE) & & & \\
\hline $\begin{array}{l}\text { Drepanolejeunea } \\
\text { anoplantha }\end{array}$ & $\begin{array}{l}\text { Ecuador, Wilson et al. 04- } \\
22 \text { (GOET) }\end{array}$ & DQ983677 & ------------ & DQ987372 \\
\hline $\begin{array}{l}\text { Drepanolejeunea } \\
\text { biocellata A. Evans }\end{array}$ & $\begin{array}{l}\text { Ecuador, Gradstein } 10053 \\
\text { (GOET) }\end{array}$ & AY548097 & DQ238578 & DQ987276 \\
\hline $\begin{array}{l}\text { Drepanolejeunea } \\
\text { granatensis (J.B. Jack \& } \\
\text { Steph.) Bischl. }\end{array}$ & $\begin{array}{l}\text { Ecuador, Schäfer- } \\
\text { Verwimp et al. 24383/B } \\
\text { (JE) }\end{array}$ & KC313121 & KC313160 & KC313081 \\
\hline $\begin{array}{l}\text { Drepanolejeunea } \\
\text { hamatifolia (Hook.) }\end{array}$ & $\begin{array}{l}\text { Azores, Schäfer-Verwimp } \\
\text { \& Verwimp 29482/A (JE) }\end{array}$ & ------------- & KC313161 & KC313082 \\
\hline teph. & & & & \\
\hline
\end{tabular}

Drepanolejeunea

Ecuador, Gradstein 10169

KC313122 KC313162 KC313083

inchoata (C.F.W. (GOET)

Meissn.) Steph.

Drepanolejeunea Dominican Republic,

KC313123

KC313084

mosenii (Steph.) Bischl. Schäfer-Verwimp \&

Verwimp 27063 (JE)

Drepanolejeunea

Ecuador, Schäfer-

KC313124 KC313163 KC313085

navicularis Steph.

Verwimp \& Nebel 31772/A

(JE) 


$\begin{array}{lllll}\text { Drepanolejeunea } & \text { Madagascar, Pócs \& } & \text { KC313125 } & \text { KC313164 } & \text { KC313086 } \\ \text { vandenberghenii } & \text { Szabó 9778/AB (EGR) } & & & \\ \text { Buchbender \& Eb } & & & \end{array}$

Buchbender \& Eb.

Fisch.

Drepanolejeunea

Malawi, Pócs 9184/D

KC313126 KC313165 KC313087

vandenberghenii

(EGR)

Drepanolejeunea

Réunion (I), Pócs 08071/L

KC313127 KC313166 KC313088

vandenberghenii (EGR)

Drepanolejeunea

Réunion (II), Pócs

KC313128 KC313167 KC313089

vandenberghenii

08071/H (EGR)

Drepanolejeunea

Rwanda, Pócs 6249

KC313168 KC313090

vandenberghenii

(Paratype, EGR)

Drepanolejeunea

Australia (I), Pócs \&

KC313129 KC313169 KC313091 vesiculosa (Mitt.) Steph. Streimann 99109/T (EGR)

Drepanolejeunea

vesiculosa

Drepanolejeunea

vesiculosa

Drepanolejeunea

vesiculosa

Drepanolejeunea

vesiculosa

Drepanolejeunea

vesiculosa

Drepanolejeunea
Australia (II), Pócs \&

AY302449

Streimann 99122 (EGR)

Indonesia (I), Gradstein 12052 (GOET)

Indonesia (II), Gradstein 10331 (GOET)

Indonesia (III), Gradstein 12026 (GOET)

Indonesia (IV), Gradstein 12014 (GOET)

Madagascar, Pócs \&
KC313131 KC313171 KC313093

KC313132 KC313172 KC313094

KC313133 KC313173 KC313095 KC313134 KC313174 KC313096 
vesiculosa

Drepanolejeunea

vesiculosa

Echinolejeunea papillata (Mitt.) R.M.Schust.

Verwimp \& Verwimp

14195/A (JE)

Echinolejeunea papillata

Verwimp \& Verwimp

13967 (JE)

Evansiolejeunea roccatii

Vanden Berghen

Frullanoides corticalis

(Lehm. \& Lindenb.) van

Slageren

Fulfordianthus evansii

(Fulford) Gradst.

Harpalejeunea filicuspis

(Steph.) Mizut.

Harpalejeunea filicuspis

Harpalejeunea filicuspis

Costa Rica, Dauphin s.n.

DQ983683

AM237197

AM237144 (GOET)

Fiji Isls. (I), Pócs \& Pócs

KC313137

KC313177 03306/R (EGR)

Fiji Isls. (II), Pócs \& Pócs 03304/A (EGR)

KC313138 KC313178 KC313100

Thailand, Pócs \& Pócs

KC313139

KC313179

KC313101 07006/A (EGR)

Harpalejeunea fischeri

Tixier

Harpalejeunea fischeri
KC313141 KC313181 KC313103

KC313140 KC313180 KC313102

\section{KC313141 KC313181 KC313103}

Uganda (I), Pócs \& Lye 97141/T (EGR)

Uganda (II), Pócs \& Lye

97142/AM (EGR) 
$\begin{array}{llll}\text { Harpalejeunea fischeri } & \text { Uganda (III), Pócs \& Lye } & \text { KC313142 } & \text { KC313182 } \\ & \text { 97142/BB (EGR) }\end{array}$

Harpalejeunea fischeri Uganda (IV), Pócs \& Lye

KC313143 KC313183 KC313105

97142/BQ (EGR)

Harpalejeunea grandis Colombia, Cleef $6450 \quad$ KC313144 KC313184 KC313106

Grolle \& M. Reiner (Paratype, GOET)

Harpalejeunea $\quad$ Ecuador, Schäfer- $\quad$ KC313145 KC313185 KC313107

grandistipula Verwimp et al. 24163/B

R.M.Schust. (JE)

Harpalejeunea latitans $\quad$ New Zealand, Schäfer- $\quad$ KC313146 KC313186 KC313108

(Hook. F. \& Tayl.) Grolle Verwimp \& Verwimp

$13869(\mathrm{JE})$

Harpalejeunea $\quad$ Chile, Schäfer-Verwimp \& KC313147 $\quad$ KC313187 $\quad$ KC313109 marginalis (Hook. $f$ \& Verwimp 8082 (JE)

Tayl.) Steph.

Harpalejeunea molleri

Azores, Schäfer-Verwimp KC313148 KC313188 KC313110

(Hook. f. \& Tayl.) Grolle \& Verwimp 29334 (JE)

Lejeunea cf. asthenica $\quad$ Bolivia, Gradstein $9948 \quad$ DQ983731 $\quad$ DQ987428 $\quad$ DQ987324

Spruce (GOET)

Lejeunea cancellata Ecuador, Wilson et al. 04- DQ983686 DQ987433 DQ987329

Nees \& Mont. ex Mont. 02 (GOET)

Lejeunea catinulifera $\quad$ Ecuador, Wilson et al. 04- DQ983687 DQ987432 DQ987328

Spruce $\quad 01$ (GOET)

Lejeunea cavifolia Germany, Heinrichs 3695 AY548102 DQ238581 DQ987259

(Ehrh.) Lindb. (GOET) 
Lejeunea cerina (Lehm. Ecuador, Wilson et al. 04- DQ983689 DQ987441 DQ987339 \& Lindeb.) Gottsche, 13 (GOET)

Lindenb. \& Nees

Lejeunea drehwaldii $\quad$ Peru, Drehwald 10014 HE995781 HE995782 HE995783

Heinrichs \& Schäf-Verw. (JE)

Lejeunea flava (Sw.) $\quad$ Brazil, Gradstein s.n. $\quad$ DQ983692 DQ987413 DQ987309

Nees (GOET)

Lejeunea cf. isocalycina Ecuador, Wilson et al. 04- DQ983733 DQ987435 DQ987331 (Nees) Spruce $\quad 04$ (GOET)

Lejeunea laetevirens $\quad$ Dominica, Schäfer- $\quad$ AY548103 DQ987402 DQ987296

Nees \& Mont. Verwimp \& Verwimp

17899 (GOET)

Lejeunea lamacerina

Canary Islands, Schäfer-

DQ983694

DQ987358

(Steph.) Schiffn.

Verwimp \& Verwimp

24616 (GOET)

Lejeunea mimula Hürl. Bali, Schäfer-Verwimp \&

AY548104 DQ238580 DQ987261 Verwimp 20930 (GOET)

Lejeunea pallescens

Mitt.

Lejeunea paucidentata

(Steph.) Grolle

Ecuador, Schäfer-

Verwimp \& Preußing

23533 (GOET)

Dominica, Schäfer-

Verwimp \& Verwimp

17737 (GOET)

Lejeunea cf. pterigonia

(Lehm. \& Lindenb.)

Bolivia, Gradstein 9964

(GOET)

Mont.

Lejeunea sp. I
Ecuador, Gradstein \& Jost $\quad$ DQ983712 DQ987416 DQ987312

AY548068 DQ238576 DQ987292

DQ983695 DQ987447 $\quad$ DQ987345

DQ983732 DQ987429 DQ987325 
10063 (GOET)

Lejeunea sp. II

Ecuador, Gradstein 10172 DQ983734 DQ987410 DQ987304 (GOET)

Lepidolejeunea

China, Koponen et al.

AY125936 AY144476 AY125340

bidentula (J.B. Jack \& $51525(\mathrm{H})$

Steph.) R.M. Schust.

Lepidolejeunea eluta

Bolivia, Drehwald 4833

DQ983696

DQ987257

(Nees) R.M.Schust.

(GOET)

Lepidolejeunea

Fiji, Pócs 03307/AC

DQ983697 DQ987417 DQ987313

integristipula (Jack \&

(GOET)

Steph.) R.M.Schust.

Lopholejeunea eulopha

Australia, Pócs \&

AY548067 DQ987381 DQ987262

(Tayl.) Schiffn.

Streimann 9987/H1

(GOET)

Luteolejeunea herzogii

Costa Rica, Schäfer-

DQ983706 DQ987467 DQ987368

(Buchloh) Piippo

Verwimp \& Holz 0294/B

(GOET)

Microlejeunea africana

Madagascar, Lübenau 2

KC313149 KC313189 KC313111

Steph.

(JE)

Microlejeunea africana

São Tomé and Principe

KC313150

KC313190

KC313112

(I), Shevock 34576 A

(GOET)

Microlejeunea africana

São Tomé and Principe

KC313151 KC313191 KC313113

(II), Shevock 34576 B

(GOET)

Microlejeunea capillaris

Costa Rica, Schäfer-

KC313152 KC313192 KC313114

(Gottsche) Steph.

Verwimp \& Holz SV/H- 
0489/B (JE)

Microlejeunea

colombiana Bischl.

Microlejeunea ulicina

(Tayl.) Steph.

Microlejeunea ulicina

Microlejeunea sp.

Macrocolura

sagittistipula (Spruce)

R.M.Schust.

Marchesinia robusta

(Mitt.) Schiffn.

Mastigolejeunea

auriculata (Wilson \&

W.J.Hooker) Schiffn.

Myriocoleopsis

gymnocolea (Steph.)

M.E. Reiner \& Gradst.

Neurolejeunea breutelii

(Gottsche) A.Evans

Omphalanthus filiformis
Dominican Republic,

KC313153 KC313193 KC313079

Schäfer-Verwimp \&

Verwimp 26614/A (JE)

Canary Isls., Schäfer-

KC313154 KC313194 KC313115

Verwimp \& Verwimp

24800 (GOET)

Canary Isls., Schäfer-

KC313155 KC313195 KC313116

Verwimp \& Verwimp

24666 (JE)

Thailand, Schäfer-

KC313156 KC313196

KC313117

Verwimp \& Verwimp

16293 (JE)

Dominica, Schäfer-

DQ983707

DQ987466

DQ987367

Verwimp \& Verwimp

18014 (GOET)

Ecuador, Wilson et al. 04-

DQ983710

DQ987436

DQ987332 05 (GOET)

Bolivia, Churchill 21275

AY548070

DQ987385

DQ987268 (GOET)

Ecuador, Gradstein et al. $\quad$ DQ238568 $\quad$ DQ238583 DQ987277 10020 (GOET)

Brazil, Schäfer-Verwimp \& DQ983714 DQ987405 DQ987299 Verwimp 14740 (GOET)

Ecuador, Schäfer-

DQ983716 DQ987393 DQ987283 
Nees

Omphalanthus ovalis

(Lindenb. \& Gottsche)
Verwimp \& Preußing

23543 (GOET)
DQ983717 07 (GOET)

Gradst.

Phys portoricensis (Hampe \&

Guadeloupe, Schäfer-

DQ983719 DQ987448 DQ987346

Gottsche) R.M.Schust.

Verwimp \& Verwimp

22615 (GOET)

Pluvianthus squarrosus

Brazil (I), Schäfer-

KC313157 KC313197 KC313118 (Steph.) R.M.Schust. \& Verwimp \& Verwimp14780

Schäf.-Verw.

(JE)

Pluvianthus squarrosus Brazil (II), Schäfer-

KC313158 KC313198 KC313119 Verwimp \& Verwimp 14638 (JE)

Pluvianthus squarrosus Brazil (III), Schäfer-

DQ983720 DQ987446 DQ987344 Verwimp \& Verwimp 13376 (GOET)

Ptychanthus striatus Java, Gradstein 10215

DQ983721 DQ987406 DQ987300 (Lehm. \& Lindenb.) (GOET)

Nees

Pycnolejeunea

Ecuador, Schäfer-

AY548075 DQ987400 DQ987294 densistipula (Lehm. \& Verwimp \& Preußing Lindenb.) Steph. 23368 (GOET)

Rectolejeunea Guadeloupe, SchäferDQ983724 DQ987444 DQ987342 berteroana (Gottsche) Verwimp \& Verwimp

A. Evans

Schiffneriolejeunea nymannii (Steph.)
22245/A (GOET)

Malaysia, Gradstein et al. $\quad$ DQ983725 DQ987424 DQ987320 10321 (GORT) 
Gradst. \& Terken

Siphonolejeunea

Australia, Pócs \& Brown

DQ983726

DQ987452 DQ987352

elegantissima (Steph.) 0026/AA (E)

Grolle

Spruceanthus

Australia, Pócs 01107/M

AM384877

DQ987460

DQ987362

thozetianus (Gottsche \& (GOET)

F. v. Müll.)

B. Thiers

Thysananthus

Bali, Schäfer-Verwimp \&

DQ983739

DQ987392 DQ987282

spathulistipus (Reinw. et Verwimp 20790 (GOET)

al.) Lindenb.

Xylolejeunea crenata $\quad$ Brazil, Schäfer-Verwimp \& DQ983740 DQ987443 DQ987341 (Nees \& Mont.) X.-L. He Verwimp 11225 (GOET)

\& Grolle

TABLE 2. Distribution of constant and phylogenetically informative sites for aligned positions of the three genomic regions.

\begin{tabular}{lllll}
\hline & rbcL & trnL-F & ITS1-5.8S-ITS2 & Total \\
\hline Number of sites in matrix & 914 & 433 & 717 & 2,064 \\
\hline constant & 634 & 202 & 280 & 1,116 \\
\hline autapomorphic & 80 & 55 & 55 & 190 \\
\hline parsimony informative & 200 & 176 & 382 & 758 \\
\hline
\end{tabular}




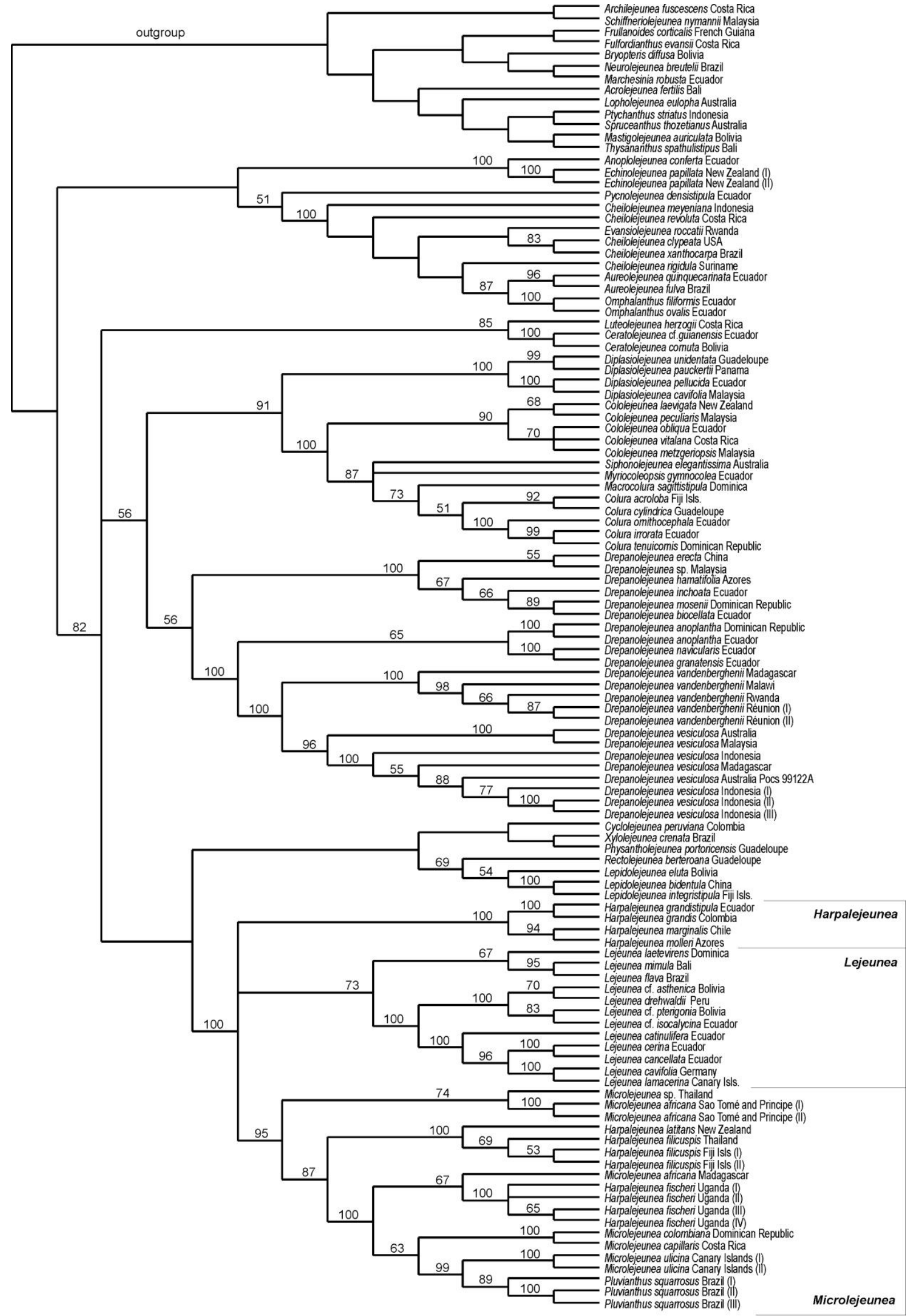

FIGURE 1. Strict consensus of 5 equally parsimonious trees based on the combined nrlTS- chloroplast DNA rbcL-trnL-F dataset with bootstrap percentage values $\geq 50$ at branches. 


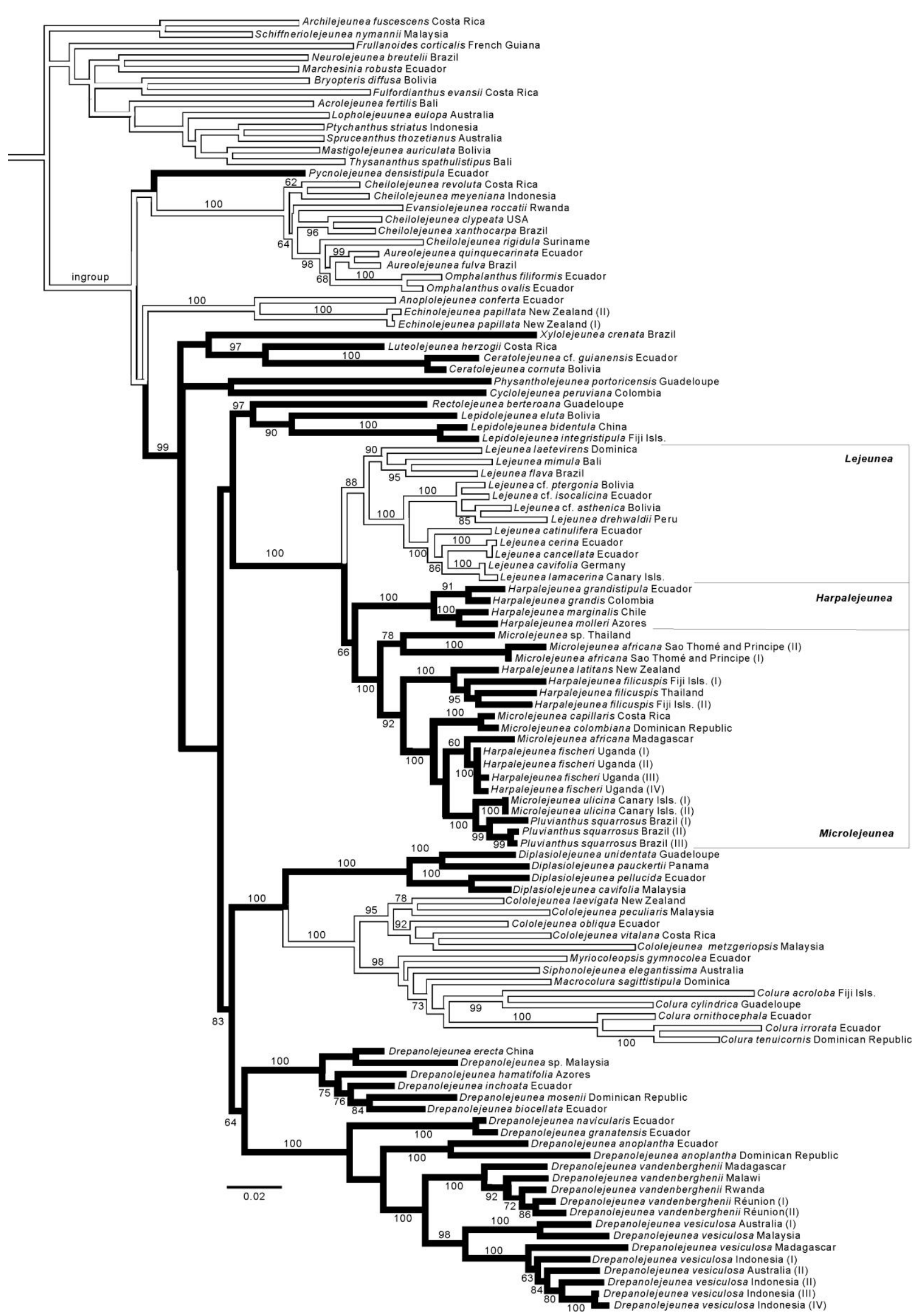

FIGURE 2. Phylogram generated in a maximum likelihood analysis of the combined dataset with bootstrap percentage values $\geq 50$ indicated at branches. Black lines: ocelli present, white lines: ocelli lacking. 


\section{Appendix 4}

\section{Molecular study of Myriocolea: A 150-year old mystery solved: Transfer of the rheophytic endemic liverwort Myriocolea irrorata to Colura}

Jochen Heinrichs, Shanshan Dong, Ying Yu, Alfons Schäfer-Verwimp, Tamás Pócs, Kathrin Feldberg, Jörn Hentschel, Alexander R. Schmidt, Harald Schneider.

Published in Phytotaxa, 2012, 66, 55-64. 


\section{Abstract}

Myriocolea irrorata is an endemic rheophytic liverwort known from a few localities in the Eastern Andes of Ecuador. Morphologically it belongs to the CololejeuneaTuyamaella clade of Lejeuneaceae, however, due to its exclusively Radula-type branching, transversely inserted, hollow leaves, large size, and an extremely high number of clustered gynoecia it has often been regarded as an isolated element of this group. Phylogenetic analyses of a molecular dataset consisting of three markers (nuclear ribosomal ITS region, plastidic trnL-F region and $r b c \mathrm{~L}$ gene) and 20 accessions resolved Myriocolea in one of the main clades of Colura, sister to the generitype Colura calyptrifolia. Based on the molecular topology and a reinterpretation of morphological traits, Myriocolea irrorata is transferred to Colura, as Colura irrorata. The example Myriocolea/Colura adds to growing evidence that rheophytic liverworts may develop unusual morphologies that hamper their classification using exclusively morphology. Key words: Lejeuneaceae, liverwort, Porellales, taxonomy

\section{Introduction}

In 1857, the English botanist Richard Spruce collected a previously unknown rheophytic liverwort along the Río Topo of the Eastern Andes of Ecuador. Describing it in a new genus of Lejeuneaceae, Myriocolea Spruce (1884: 305), he stated that "anything more alien from the aspect of a Lejeunea cannot well be imagined" (Spruce 1884: 307). Using a very wide genus concept for Lejeunea Libert (1820: 372), Spruce only accepted two genera in Lejeuneaceae, Lejeunea with several hundreds of species, and the monospecific Myriocolea with its single representative Myriocolea irrorata Spruce (1884: 305). This species differs from all other Lejeuneaceae by the exclusive presence of Radula-type branches, transversely inserted leaves without well delimited lobuli, presence of numerous antheridia per bract, and an extraordinary high number of clustered gynoecia (Thiers 1983, Gradstein et al. 2004). By its up to ca. $5 \mathrm{~cm}$ long, stiff, protruding leafy shoots it is easily recognizable in the field, however, was not redetected until 2002. It grows on twigs of shrubs occurring along the Topo and Zuñac rivers, especially on the periodically submerged riverbanks (Gradstein \& Nöske 2002, Gradstein et al. 2004). 
The systematic position of the monospecific genus Myriocolea has been subject to controversy. Schuster (1963a: 93) set up a new subfamily Myriocoleoideae to include Myriocolea and Cladocolea Schuster (1963a: 155), hom. illeg. [= Schusterolejeunea Grolle (1980: 105)], a taxon treated as a synonym of Lejeuneoideae by Gradstein (1994). The latter treatment was also supported by cladistic analyses of morphological character states of Lejeuneaceae (Gradstein et al. 2003) where Myriocolea was resolved in an unsupported Cololejeunea-Tuyamaella clade. This relationship was also recovered by several molecular phylogenies based on one or two molecular markers (Wilson et al. 2004; Gradstein et al. 2006). Phylogenetic analyses of a comprehensive four molecular marker set of Lejeuneaceae consistently located Myriocolea in a clade with Macrocolura Schuster (1994: 233) and Colura (Dumortier 1831: 32) Dumortier (1835: 12) (Wilson et al. 2007a). However, the lack of taxonomic sampling of these two genera hampered the discovery of the true relationships of Myriocolea. Addition of further Colura sequences to the published ones pointed to a possible close relationship of the genera Colura and Myriocolea ( $\mathrm{Yu}$ et al., unpublished). Here we present the results of phylogenetic analyses of a dataset comprising two chloroplast genome regions and one nuclear genome region and a comprehensive taxonomic sampling of Macrocolura, Myriocolea and 15 accessions of Colura.

\section{Materials and Methods}

Taxa studied, including GenBank accession numbers and voucher details, are listed in Table 1. Besides availability of material, ingroup taxa were selected to represent the morphological variation and geographical distribution of Colura. Multiple accessions of several species were used to explore intraspecific genetic variation. Based on the analyses of Wilson et al. (2007a), Cololejeunea laevigata (Mitten 1855: 157) Schuster (1963b: 241) and Cololejeunea vitalana Tixier (1995: 230) were designated as outgroup taxa for phylogenetic reconstruction. The ingroup includes accessions of Colura and Macrocolura. 


\section{DNA extraction, PCR amplification and sequencing}

Plant tissue was isolated from herbarium collections housed at the herbaria EGR, GOET and JE. Total genomic DNA was purified using Invisorb Spin Plant Mini Kit (Invitek, Berlin, Germany) prior to amplification. Protocols for PCR were carried out as described in previous publications: $r b c \mathrm{~L}$ gene and $t r n L-F$ region from Gradstein et al. (2006), and nrlTS1-5.8S-ITS-2 region from Hartmann et al. (2006). Bidirectional sequences were generated using a MegaBACE 1000 automated sequencing machine using DYEnamic ET Primer DNA Sequencing Reagent (Amersham Biosciences, Little Chalfont, UK). Sequencing primers were those used for PCR. Thirty six sequences were newly generated for this study and 21 sequences were downloaded from GenBank (http://www.ncbi.nlm.nih.gov/genbank/).

\section{Phylogenetic analyses}

All sequences were aligned manually in Bioedit version 7.0.5.2 (Hall 1999). Ambiguous positions were excluded from all alignments. Maximum parsimony (MP) and maximum likelihood (ML) analyses were carried out with PAUP* version 4.0b10 (Swofford 2000). MP heuristic searches were conducted with the following options implemented: heuristic search mode, 1,000 random-addition-sequence replicates, tree bisection-reconnection (TBR) branch swapping, MULTrees option on, and collapse zerolength branches off. All characters were treated as equally weighted and unordered. Non-parametric bootstrapping values (Felsenstein 1985) were generated as heuristic searches with 1,000 replicates, each with ten random-addition replicates. Bootstrap percentage values (BPV) $\geq 70$ were regarded as good support (Hillis \& Bull 1983). The individual marker sets and the combined chloroplast DNA dataset vs. nrITS dataset were first analysed separately to check for incongruence. The strict consensus trees of the non-parametric bootstrap analyses were compared by eye to identify conflicting nodes supported by at least $70 \%$ (Mason-Gamer \& Kellogg 1996). The trees gave no evidence of incongruence. Hence the datasets were combined.

jModeltest 0.1 (Posada 2008) was used to select a model of evolution for ML analyses of the combined dataset. A General Time Reversible (GTR) model (Tavaré 1986) was chosen with among-site rate heterogeneity modelled as discrete gamma distribution with 
four rate categories, and its estimated parameters $(\Gamma)$ (Goldman 1993). The ML-Analysis was performed as heuristic search, MULTrees option on, collapse zero length branches off, and TBR branch swapping. The confidence of branching was assessed using 300 non-parametric bootstrap resamplings generated as heuristic searches.

\section{Results}

Of the 2,321 investigated molecular characters, 468 were parsimony informative and 166 autapomorphic (see Table 2 for character state distributions within the single markers). The MP analysis resulted in a single tree of 304 steps with a consistency index of 0.696 and a retention index of 0.774 (not depicted). The ML analysis likewise resulted in a single tree (Figure 1) that confirmed the MP topology. Macrocolura was placed sister to the well supported Colura-clade. Colura comprised two main clades with ML/MP bootstrap percentage values of 99 and 100 respectively. One main clade included only Neotropical accessions of Colura [Colura calyptrifolia (Hooker 1813: pl. 43) Dumortier (1835: 12), C. ornithocephala Herzog (1952a: 107), C. rhynchophora JovetAst (1948: 27), C. tenuicornis (Evans 1900: 455) Stephani (1916: 942)] as well as the monospecific genus Myriocolea. The generitype of Colura, C. calyptrifolia, was placed sister to a clade with two accessions of Myriocolea. This sister relationship achieved a ML bootstrap percentage value of 100 and a MP value of 99 . The second main clade of Colura separated into a robust Asian-Australasian clade comprising C. inflata Goebel (1928: 11) and C. acroloba (Stephani 1890: 97) Jovet-Ast (1953: 297) and a clade with Australasian [C. imperfecta Stephani (1916: 938)], African [C. digitalis (Mitten 1886: 325) Stephani (1916: 931)] and tropical American accessions [C. cylindrica Herzog (1952a: 106), C. tortifolia (Montagne 1843: 265) Trevisan de Saint-Léon (1877: 402)]. The African accession was placed sister to the Neotropical clade in a robust sister relationship. Multiple accessions of several morphologically circumscribed species formedrobust monophyletic lineages with bootstrap percentage values between 93 and 100.

Based on the molecular topology and adopting a monophyly approach we transfer Myriocolea irrorata to Colura: 
Colura (Dumortier 1831: 32) Dumortier (1835: 12)

= Myriocolea Spruce (1884: 305), syn. nov.

Colura irrorata (Spruce) Heinrichs, Y.Yu, Schäf.-Verw. \& Pócs, comb. nov. Basionym: Myriocolea irrorata Spruce (1884: 305).

Type:- ECUADOR, Tungurahua, Río Topo, Spruce s.n. (isotype, G).

\section{Discussion}

\section{Classification: General trends}

Morphology based classification systems often include small or even monospecific genera. However, modern broad scaled taxonomical studies tend to the acceptance of larger genera and incorporation of many small taxonomic entities, especially when molecular data are included and a monophyly approach is adopted (Humphreys \& Linder 2009). Although molecular studies may lead to the division of large genera such as Jungermannia Linnaeus (1753: 1131) (Hentschel et al. 2007b), there is a general trend towards larger genus concepts. Phylogenetic analyses repeatedly demonstrated that the character states separating small genera may in fact represent autapomorphies of taxa nested in larger genera (e.g., Heinrichs et al. 2003). Small genera of liverworts that have recently been synonymized with larger genera based on phylogenetic evidence and reinterpretation of morphological character states include Rhodoplagiochila Schuster (1978: 247), Steereochila Inoue (1987: 279), Szweykowskia Gradstein \& Reiner-Drehwald (1995: 33) [= Plagiochila (Dumortier 1831: 42) Dumortier (1835: 14), Heinrichs et al. 2004], Metzgeriopsis Goebel (1888: 54) [= Cololejeunea (Spruce 1884: 291) Schiffner (1893: 121), Gradstein et al. 2006], Pachyglossa Herzog \& Grolle (1959: 150) [= Chiloscyphus Corda (1829: 651), Hentschel et al. 2007a] and Perssoniella Herzog (1952b: 268) [= Schistochila Dumortier (1835: 15), He \& Glenny 2010]. The transfer of Myriocolea to Colura thus confirms a general trend in plant systematics.

\section{Colura and Myriocolea}


Colura is a large pantropical genus comprising about 70 species (Jovet-Ast 1953, Gradstein et al. 2001, Grolle \& Zhu 2002) of which eleven species were investigated in our study. Species of Colura are typically recognized by their leaf morphology: the presence of lobules forming an apical sac with an aperture mechanism consisting of a valve and a hinge. This sac varies greatly in size and shape, and may function for water retention and in some species also for zoophagy (Barthlott et al. 2000). Colura species grow in well-illuminated sites from the lowlands to about $4,000 \mathrm{~m}$ above sea level, usually as epiphytes on twigs and trunks or on leaves, as epiphylls.

At first glance, the position of Myriocolea irrorata in the Colura sect. Colura clade is surprising. However, Thiers (1983) points out that the unique aspect of Myriocolea irrorata results from an exaggeration of conditions found elsewhere in the Lejeuneaceae whereas an exclusively Radula-type branching is otherwise unknown in Lejeuneaceae. However, Radula-type branches in combination with Lejeunea-type branches occur, e.g., in several species of Lejeunea (Schuster 1994, Reiner-Drehwald 2000a, 2005).

Morphological support for the synonymy of Myriocolea and Colura comes from the number of underleaves. Usually, Lejeuneaceae have one underleaf per leaf pair, however, a few exceptions prove the rule (Gradstein et al. 2003). The presence of one underleaf per leaf characterizes Colura, Diplasiolejeunea (Spruce 1884: 301) Schiffner (1893: 121), Macrocolura and Myriocolea, the latter being here identified as an element of Colura. Colura (Myriocolea) irrorata does not produce well-developed lobules; however, the ventral part of the hollow leaves may be interpreted as an incompletely inrolled, large lobule. Other members of Colura sect. Colura are characterized by a lobule consisting of a sac terminated by a long, conico-cylindric, elongate horn (Grolle \& Zhu 2002). Colura irrorata is not the only species of Colura without a well-developed lobule. In Colura sect. Heterophyllum Jovet-Ast (1983: 213) there is also a tendency to lose the lobule, which is very much reduced or completely missing in Colura corynephora (Nees, Lindenberg \& Gottsche in Meyen 1843: 474) Trevisan de SaintLéon (1877: 402), a phenomenon that parallels the situation in Colura irrorata. This fact also raises the classification problem of Calatholejeunea Goebel (1928: 8), which generally resembles Colura by its pendular segmentation and Colura irrorata by its transversely inserted, hollow leaves with unsharply defined lobules. Calatholejeunea 
was morphologically compared to Colura by Mizutani (1984) but its molecular phylogeny has not yet been studied.

Colura irrorata is a rheophilous liverwort growing on twigs of shrubs on the periodically inundated riverbanks of the Río Topo. The rheophytic, nutrient-rich habitat may explain the untypical leaf development of Colura irrorata because a structure for water storage or zoophagy is not needed in such an environment. Rheophytes from different taxonomic groups exhibit a parallel development, because running waters and regular flooding shape them into flood resistant plants (Van Steenis 1981). Accordingly, Colura irrorata shares its long, robust stems, pinnate branching, and the presence of numerous small gametoecial branches with other rheophytic Lejeuneaceae, namely Myriocoleopsis Schiffner (1944: 234), Lejeunea subg. Neopotamolejeunea (Reiner-Drehwald 2000b: 449) Gradstein \& Reiner-Drehwald (2007: 484) (Wilson et al. 2007a) and Cololejeunea stotleriana (Gradstein et al. 2011: 13). Non-rheophytic Colura species have a smaller size, grow usually attached to the substratum, have sac-like lobules, a lower number of gametoecia, and less robust stems. However, the phylogenetic distance between Colura irrorata and other members of $C$. sect. Colura is low (Fig. 1), indicating that the rheophytic species $C$. irrorata originated in rather recent times. This scenario is also supported by the derived position of $C$. irrorata. It is likely that the Ecuadorian endemic $C$. irrorata evolved from a local population of a species close to $C$. calyptrifolia and $C$. tenuicornis, and that the morphological rearrangements of the gametophyte took place in a short period of time. A rapid reorganization of gametophytical traits has also been demonstrated for some epiphytic representatives of Plagiochila sect. Hylacoetes Carl (1931: 50) (Heinrichs et al. 2003), providing some evidence that an occurrence in extreme habitats may occasionally lead to considerable changes in morphology. The molecular control procedures of such rapid rearrangements and their contribution to plant evolution are still incompletely understood (Stern 2000, Carroll 2008, Theissen 2009, Frankel et al. 2011). However, rheophytic plants appear to be an excellent group on which to study the impact of selection on the establishment of rapid growth habit changes. Research on Japanese occurrences of the terrestrial fern Osmunda japonica Thunberg (1780: 209) and the rheophytic O. lancea Thunberg (1784: 330) showed that habitat conditions may lead to dramatic changes of the leaf morphology in sister taxa 
that otherwise share more or less the same genetic information (Imaichi \& Kato 1992; Yatabe et al. 2009).

\section{Species concepts and supraspecific classification of Colura}

Colura species have so far been described using a morphological-typological approach. Multiple accessions of several morphologically circumscribed species form monophyletic lineages (C. acroloba, C. cylindrica, C. imperfecta, C. irrorata, C. ornithocephala, C. tortifolia, Fig. 1), indicating congruence of morphological and phylogenetic species concepts.

Grolle \& Zhu (2002) provided the most recent classification of Colura. They split Colura into two subgenera and six sections, and accepted the monospecific genus Macrocolura based on its asymmetrically shaped, only weakly bifid underleaves with rhizoid fascicles originating from their central part. Colura, in contrast, has symmetrical, deeply bifid underleaves with rhizoid fascicles originating at the base of the underleaves. Earlier, Macrocolura was treated as Colura sect. Lingua Jovet-Ast ex Thiers (1987: 177). In our study, Macrocolura is placed sister to Colura, hence both treatments appear consistent with the recovered phylogeny. Based on the molecular topology and the morphological disparities, we tentatively accept Macrocolura as a genus. This taxonomic position, however, should be scrutinized by an extension of the Colura taxon sampling.

The classification of Colura into subg. Colura with hinged valves and subg. Glotta Grolle \& Zhu (2002: 187) having valves without a distinct hinge (Grolle \& Zhu 2002), is not confirmed in our study because $C$. subg. Glotta (represented in our study by $C$. sect. Heterophyllum) nests in C. subg. Colura (Fig. 1). In total, we included members of four out of six Colura sections in our sampling. Sections Colura (following inclusion of Myriocolea), Harmophyllum Grolle (1965: 44) and Oidocorys Jovet-Ast ex Grolle (1969: 140) were resolved as monophyletic entities. Colura sect. Heterophyllum is paraphyletic because $C$. sect. Harmophyllum nests in it. Grolle \& Zhu (2002) included species with rounded valves in Colura sect. Heterophyllum, however, according to our topology this section should be split in two entities, of which the $C$. imperfect clade represents $C$. sect. Heterophyllum s. str. (Grolle \& Zhu 2002). Our sampling, however, is too sparse to reinterpret morphological traits in $C$. sect. Heterophyllum s. I. The formal denomination 
of the $C$. acroloba- $C$. inflata clade should thus await a more comprehensive study, which should also consider representatives of C.sect. Gamolepis Jovet-Ast (1983: 207) and Glotta Grolle \& Zhu (2002: 187).

\section{Biogeography}

A phylogenetic analysis of the largely epiphyllous genus Diplasiolejeunea revealed a remarkably clear geographical structure with several Neotropical and Paleotropical lineages (Dong et al. 2012). A similar structure is seen in the epiphytic-epiphyllous genus Colura, containing Asian-Australasian, Neotropical and African lineages (Fig. 1). The occurrence of a relatively high number of Colura species on isolated and young oceanic islands such as Fiji (Pócs \& Eggers 2007) is best explained by long-distance dispersal through propagules; however, the clear geographical pattern within the genus seems to indicate that long distance dispersal occurs only occasionally. The range of the Cenozoic genus Colura (Wilson et al. 2007b) is possibly the result of rare long distance dispersal, frequent short-distance dispersal, local diversification, extinction and recolonization, processes that likely shaped the ranges of numerous other genera of leafy liverworts (Heinrichs et al. 2009). A more detailed biogeographic reconstruction needs a considerable extension of the taxon sampling and inclusion of multiple accessions of species with broad ranges.

\section{Acknowledgements}

JHei and ASV thank Hugo Navarrete, Susanna León-Yánez and Santiago Yandún (Herbarium QCA, Quito) for logistic support during fieldwork in Ecuador. This study was supported by the Deutsche Forschungsgemeinschaft [grants He 3584/2, HE 3584/4, Gr 1588/9 and LE1826/4]. SD was supported by the China Scholarship Council (scholarship No. 2010697001). YY acknowledges financial support by the Chinese student council (Fellowship No.: 2010614081), HS the senior visiting professorship granted by the Chinese Academy of Sciences. This is publication number 104 from the Courant Research Centre Geobiology that is funded by the German Initiative of Excellence. 


\section{References}

Barthlott, W., Fischer, E., Frahm, J.P. \& Seine, R. (2000) First experimental evidence for zoophagy in the hepatic Colura. Plant Biology 2: 93-97.

Carl, H. (1931) Die Arttypen und die systematische Gliederung der Gattung Plagiochila Dum. Annales Bryologici, supplement 2: 1-170.

Carroll, S.B. (2008) Evo-devo and an expanding evolutionary synthesis: a genetic theory of morphological evolution. Cell 134: 25-36.

Corda, A.J.C. (1829) Genera Hepaticarum. Die Gattungen der Lebermoose. Naturalientausch 12: 643-655.

Dong, S., Schäfer-Verwimp, A., Meinecke, P., Feldberg, K., Bombosch, A., Pócs, T., Schmidt, A.R., Reitner, J., Schneider, H. \& Heinrichs, J. (2012) Tramps, narrow endemics and morphologically cryptic species in the epiphyllous liverwort Diplasiolejeunea. Molecular Phylogenetics and Evolution 65: 582-594.

Dumortier, B.C.J. (1831) Sylloge Jungermannidearum Europae indigenarum: earum genera et species systematice complectens. Casterman, Tournay, $100 \mathrm{pp}$.

Dumortier, B.C.J. (1835) Recueil d'Observations sur les Jungermanniacées. Blanquart, Tournay, $27 \mathrm{pp}$.

Evans, A.W. (1900) The Hawaiian Hepaticae of the tribe Jubuloideae. Transactions of the Connecticut Academy of Arts and Sciences 10: 387-462.

Felsenstein, J. (1985) Confidence limits on phylogenies: an approach using the bootstrap. Evolution 39: 783-791.

Frankel, N., Erezylmaz, D.F., McGregor, A.P., Wang, S., Payre, F., Stern, D.L. (2011) Morphological evolution caused by many subtle-effect substitutions in regulatory DNA. Nature 474: 598-603. 
Goebel, K.I.E. (1888) Morphologische und biologische Studien I: Über epiphytische Farne und Muscineen. Annales du Jardin Botanique de Buitenzorg 7: 1-73.

Goebel, K.I.E. (1928) Morphologische und biologische Studien XII: Malesische Lebermoose. Annales du Jardin Botanique de Buitenzorg 39: 1-116.

Gradstein, S.R. (1994) Lejeuneaceae: Ptychantheae, Brachiolejeuneae. Flora Neotropica Monograph 62: 1-217.

Gradstein, S.R., Churchill, S.P. \& Salazar-Allen, N. (2001) Guide to the bryophytes of tropical America. Memoirs of the New York Botanical Garden 86: 1-577.

Gradstein, S.R., Ilkiu-Borges, A.L. \& Vanderpoorten, A. (2011) Habitat specialization triggers the evolution of unusual morphologies - the case of Cololejeunea stotleriana sp. nov. from Ecuador. The Bryologist 114: 9-22.

Gradstein, S.R. \& Nöske, N. (2002) The extraordinary hepatic Myriocolea irrorata rediscovered. Bryological Times 107: 16.

Gradstein, S.R., Reiner-Drehwald, M.E. \& Jost, L. (2004) The systematic position and distribution of Myriocolea irrorata (Lejeuneaceae), an endangered liverwort of the Ecuadorian Andes. Journal of the Hattori Botanical Laboratory 95: 235-248.

Gradstein, S.R. \& Reiner-Drehwald, M.E. (1995) Szweykowskia, a new genus of Plagiochilaceae from tropical America. Fragmenta Floristica et Geobotanica 40: 31-38.

Gradstein, S.R. \& Reiner-Drehwald, M.E. (2007) The status of Neopotamolejeunea (Lejeuneaceae) and description of a new species from Ecuador and Southern Brazil. Systematic Botany 32: 487-492.

Gradstein, S.R., Reiner-Drehwald M.E. \& Schneider, H. (2003) A phylogenetic analysis of the genera of Lejeuneaceae (Hepaticae). Botanical Journal of the Linnean Society 143: 391-410. 
Gradstein, S.R., Wilson, R., Ilkiu-Borges, A.L. \& Heinrichs, J. (2006) Phylogenetic relationships and neotenic evolution of Metzgeriopsis (Lejeuneaceae) based on chloroplast DNA sequences and morphology. Botanical Journal of the Linnean Society 151: 293-308.

Grolle, R. (1965) Lebermoose aus Neuguinea. I. Journal of the Hattori Botanical Laboratory 28: 43-54.

Grolle, R. (1969) Novae Guineae Hepaticae Schusteranae. I. Journal of the Hattori Botanical Laboratory 32: 140-144.

Grolle, R. (1980) Schusterolejeunea Grolle nom. nov. statt Cladocolea Schust. 1963, non van Tieghem 1895. Journal of Bryology 11: 105-106.

Grolle, R. \& Zhu, R.L. (2002) On Macrocolura and the subdivision of Colura (Lejeuneaceae, Hepaticae). Journal of the Hattori Botanical Laboratory 92: 181-190.

Hall, T.A. (1999) BIOEDIT: a user-friendly biological sequence alignment editor and analysis program for Windows 95/98/NT. Nucleic Acids Symposia Series 41: 95-98.

Hartmann, F.A., Wilson, R., Gradstein, S.R., Schneider, H. \& Heinrichs, J. (2006) Testing hypotheses on species delimitations and disjunctions in the liverwort Bryopteris (Jungermanniopsida: Lejeuneaceae). International Journal of Plant Sciences 167, 1205-1214.

He, X. \& Glenny, D. (2010) Perssoniella and the genera of Schistochilaceae: a new classification based on molecular phylogenies. Australian Systematic Botany 23: 229238.

Heinrichs, J., Gradstein, S.R., Groth, H. \& Lindner, M. (2003) Plagiochila cucullifolia var. anomala var. nov. from Ecuador, with notes on discordant molecular and morphological variation in Plagiochila. Plant Systematics and Evolution 242: 205-216. 
Heinrichs, J., Hentschel, J., Feldberg, K., Bombosch, A. \& Schneider, H. (2009): Phylogenetic biogeography and taxonomy of disjunctly distributed bryophytes. Journal of Systematics and Evolution. 47: 497-508.

Heinrichs, J., Lindner, M. \& Pócs, T. (2004) nrDNA internal transcribed spacer data reveal that RhodoplagiochilaR.M.Schust. (Jungermanniales, Marchantiophyta) is a member of Plagiochila sect. Arrectae Carl. Organisms Diversity and Evolution 4: 109118.

Hentschel, J., Feldberg, K., Zündorf, H.-J., Hellwig, F.H., Schneider H. \& Heinrichs, J. (2007a) The systematic position of Pachyglossa and Clasmatocolea (Jungermanniopsida: Lophocoleaceae) inferred from nrDNA ITS sequences and morphology. Taxon 56: 1136-1142.

Hentschel, J., Paton, J.A., Schneider, H. \& Heinrichs, J. (2007b) Acceptance of Liochlaena Nees and Solenostoma Mitt., the systematic position of Eremonotus Pearson and notes on Jungermannia L. s.l. (Jungermanniidae) based on chloroplast DNA sequence data. Plant Systematics and Evolution 268: 147-157.

Herzog, T. (1952a) Hepaticae Ecuadorienses a cl. D:re Gunnar Harling annis 1946-1947 lectae. Svensk Botanisk Tidskrift 46: 62-108.

Herzog, T. (1952b) Perssoniella Herz. nov. gen. hepaticarum. Arkiv för Botanik utgivet av K. Svenska Vetenskapsakademien 2: 265-269.

Herzog, T. \& Grolle, R. (1959 [“1958”]) Was ist Pachyglossa? Revue Bryologique et Lichénologique 27: 147-165.

Hillis, D.M. \& Bull, J.J. (1993) An empirical test of bootstrapping as a method for assessing the confidence in phylogenetic analysis. Systematic Biology 42: 182-192.

Hooker, W.J. (1813) British Jungermanniae: being a history and description, with colored figures, of each species of the genus, and microscopical analyses of the parts. Part 11, plates 41-44. Longman et al., London. 
Humphreys, A.M. \& Linder, H.P. (2009) Concept versus data in delimitation of plant genera. Taxon 58: 1054-1074.

Imaichi, R. \& Kato, M. (1992) Comparative leaf development of Osmunda lancea and O. japonica (Osmundacae): Heterochronic origin of rheophytic stenophylly. The Botanical Magazine, Tokyo 105: 199-213.

Inoue, H. (1987) Steereochila, a new genus of the Plagiochilaceae from the Neotropics. Memoirs of the New York Botanical Garden 45: 279-282.

Jovet-Ast, S. (1948) Hépatiques des Antilles françaises récoltées par P. et V. Allorge en 1936. Revue Bryologique et Lichénologique 17: 24-34.

Jovet-Ast, S. (1953) Le genre Colura. Revue Bryologique et Lichénologique 22: 206-312.

Jovet-Ast, S. (1983) Colura nouveaux d'origines diverses (Hépatiques, Lejeunéacées). Cryptogamie, Bryologie Lichénologie 4: 205-216.

Libert, M. (1820) Sur un genre nouveau d'Hépatiques, Lejeunia. Annales Générales des Sciences Physiques 6: 372-374.

Linnaeus, C. (1753) Species Plantarum, ed. 1, Holmiae [Stockholm], 1200 pp.

Mason-Gamer, R.J. \& Kellogg, E.A. (1996) Testing for phylogenetic conflict among molecular data sets in the tribe Triticeae (Gramineae). Systematic Biology 45: 524545.

Meyen, F.J.F. (1843) Observationes Botanicas in itinere circum terram institutas. Opus posthumum. Sociorum Academiae curis suppletem. Novorum actorum Academiae Caesareae Leopoldino-Carolinae Naturae Curiosorum, v. 19, suppl. 1, 512 pp.

Mitten, W. (1855) Flora Novae Zelandiae 2: Flowerless plants. Reeve, London, 378 pp.

Mitten, W. (1886) The mosses and hepaticae collected in Central Africa by the late Right Rev. James Hannington, bishop of Mombasa, F.L.S., F.G.S., \&c., with some others, 
including those gathered by Mr. H. H. Johnston on Kilimanjaro. Journal of the Linnean Society of London, Botany 22: 298-329.

Mizutani, M. (1984) Notes on the Lejeuneaceae 7. Calatholejeunea paradoxa, C. lamii (sp. nov.) and Plagiolejeunea zantenii (gen. et sp. nov.). Journal of Hattori Botanical Laboratory 56: 331-338.

Montagne, C. (1843) Quatrième centurie de plantes cellulaires exotiques nouvelles, décades I-VI. Annales des Sciences Naturelles; Botanique Sér. 2 19: 238-266.

Pócs, T. \& Eggers, J. (2007) Bryophytes from the Fiji Islands, II. An account of the genus Colura, with the description of $C$. vitiensis sp. nov. Polish Botanical Journal 52: 81-92.

Posada, D. (2008) jModelTest: Phylogenetic model averaging. Molecular Biology and Evolution 25: 1253-1256.

Reiner-Drehwald, M.E. (2000a) Las Lejeuneaceae (Hepaticae) de Misiones, Argentina VI. Lejeunea y Taxilejeunea. Tropical Bryology 19: 81-131.

Reiner-Drehwald, M.E. (2000b) On Potamolejeunea and Neopotamolejeunea gen. nov. (Lejeuneaceae, Hepaticae). Nova Hedwigia 71: 447-464

Reiner-Drehwald, M.E. (2005) On Lejeunea rotundifolia and Dicladolejeunea (Lejeuneaceae, Jungermanniopsida). Systematic Botany 30: 687-692.

Schiffner, V. (1893) Hepaticae. In: Engler, A. \& Prantl, K., Die natürlichen Pflanzenfamilien 1. Engelmann, Leipzig, pp. 97-141.

Schiffner, V. (1944) Myriocoleopsis, eine neue Gattung der Jubuleae. Hedwigia 81: 234237.

Schuster, R.M. (1963a) An annotated synopsis of the genera and subgenera of Lejeuneaceae. Beihefte zur Nova Hedwigia 9: 1-203. 
Schuster, R.M. (1963b) Studies on antipodal Hepaticae. I. Annotated keys to the genera of antipodal Hepaticae with special reference to New Zealand and Tasmania. Journal of the Hattori Botanical Laboratory 26: 185-309.

Schuster, R.M. (1978) Studies on Venezuelan Hepaticae, I. Phytologia 39: 239-251.

Schuster, R.M. (1994) Studies on Lejeuneaceae, I. Preliminary studies on new genera and subgenera of Lejeuneaceae. Journal of the Hattori Botanical Laboratory 75: 211235.

Spruce, R.M. (1884) Hepaticae Amazonicae et Andinae. Tribus I: Jubulae. Transactions and Proceedings of the Botanical Society Edinburgh 15: 1-308.

Stephani, F. (1890) Die Gattung Lejeunea im Herbarium Lindenberg. Hedwigia 29: 6899.

Stephani, F. (1916) Colura. Species Hepaticarum V, Georg \& Cie, Geneva, pp. 929-943.

Stern, D.L. (2000) Perspective: Evolutionary developmental biology and the problem of variation. Evolution 54: 1079-1091.

Swofford, D.L. (2000) PAUP*, phylogenetic analyses using parsimony ( ${ }^{*}$ and other methods), version 4.01b10. Sinauer Associates, Sunderland, Massachusetts.

Tavaré, S. (1986) Some probabilistic and statistical problems on the analysis of DNA sequences. Lectures on Mathematics in the Life Sciences 17: 57-86.

Theissen, G. (2009) Saltational evolution: hopeful monsters are here to stay. Theory in Biosciences 128: 43-51.

Thiers, B.M. (1983) Branching in Lejeuneaceae II. Nipponolejeuneoideae, Tuyamaelloideae and Myriocoleoideae. Lindbergia 10: 4-18.

Thiers, B.M. (1987) A preliminary account of Colura (Hepaticae, Lejeuneaceae) in Australia. Brittonia 39: 175-179. 
Thunberg, C.P. (1780) Kaempferus Illustratus. Explicatio illarum plantarum quas Kaempferus in laponia collegit [...]. Nova Acta Regiae Societatis Scientiarum Upsaliensis 3: 196-209.

Thunberg, C.P. (1784) Flora Japonica. G. Müller, Leipzig, 511 pp.

Tixier, P. (1995) Rectifications nomenclaturales - typifications. Cryptogamie, Bryologie, Lichénologie 16: 229-230.

Trevisan de Saint-Léon, V. (1877) Schema di una nuova classificazione delle epatiche. Memorie del Reale Istituto Lombardo di Scienze e Lettere, Serie 3, Classe di Scienze Matematiche e Naturali 4: 383-451.

Van Steenis, C.G.G. (1981) Rheophytes of the world. Sijthoff \& Noordhoff, Alphen aan den Rijn, 408 pp.

Wilson, R., Gradstein, S.R., Heinrichs, J., Groth, H., Ilkiu-Borges, A.L. \& Hartmann, F.A. (2004) Phylogeny of Lejeuneaceae: A cladistic analysis of chloroplast gene $r b c L$ and morphology with preliminary comments on the mitochondrial nad4-2 spacer region. Monographs in Systematic Botany from the Missouri Botanical Garden 98: 189-202.

Wilson, R., Gradstein, S.R., Schneider, H. \& Heinrichs, J. (2007a) Unravelling the phylogeny of Lejeuneaceae (Jungermanniopsida): evidence for four main lineages. Molecular Phylogenetics and Evolution 43: 270-282.

Wilson, R., Heinrichs, J., Hentschel, J., Gradstein, S.R. \& Schneider, H. (2007b) Steady diversification of derived liverworts under Tertiary climatic fluctuations. Biology Letters 3: $566-569$.

Yatabe, Y., Tsutsumi, C., Hirayama, Y., Mori, K., Murakami, N. \& Kato, M. (2009) Genetic population structure of Osmunda japonica, rheophilous Osmunda lancea and their hybrids. Journal of Plant Research 122: 585-595. 
TABLE 1. Taxa used in the present study, including information about the origin of the studied material, voucher information, and the herbarium where the voucher is deposited, as well as GenBank accession numbers. Sequences in bold were obtained from GenBank.

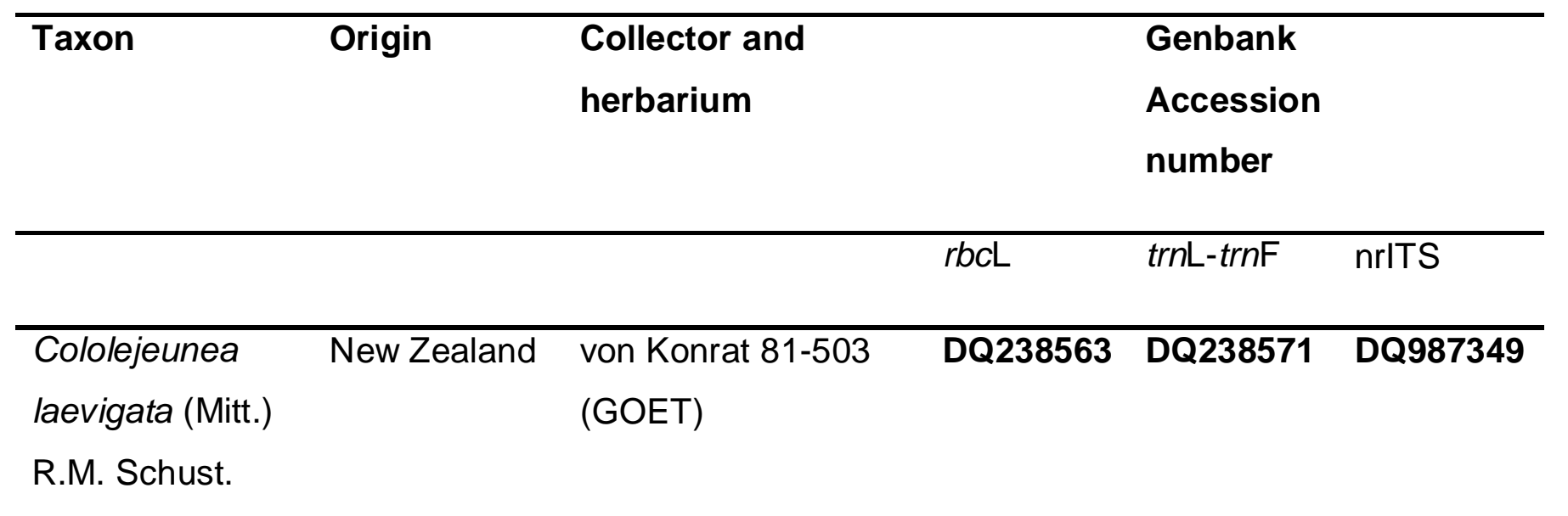

\begin{tabular}{llllll}
\hline $\begin{array}{l}\text { Cololejeunea } \\
\text { vitalana Tixier }\end{array}$ & Costa Rica & Schäfer- Verwimp \& & DQ238564 & DQ238573 & DQ987348 \\
& & Holz SV/H- & & & \\
& & & & \\
& & & & \\
& & & &
\end{tabular}

\begin{tabular}{llllll}
\hline Colura acroloba & Fiji Isls. & Pócs 03261/BK & DQ238565 & DQ238586 & DQ987306
\end{tabular}
(Mont. ex

Steph.) Jovet-

(GOET)

Ast

\begin{tabular}{llllll}
\hline Colura acroloba & Malaysia & $\begin{array}{l}\text { Schäfer-Verwimp \& } \\
\text { Verwimp }\end{array}$ & JX470966 & JX470977 & JX470989 \\
& & & & \\
& & 18860/A (JE) & & & \\
\hline Colura & Dominican & Schäfer-Verwimp \& & JX470970 & JX470981 & JX470993 \\
calyptrifolia & Republic & Verwimp 26843 (JE) & & & \\
(Hook.) Dumort. & & & & & \\
& & & & & \\
\hline Colura cylindrica & Guadeloupe & Schäfer-Verwimp \& & JX470969 & JX470980 & JX470992 \\
Herzog & & Verwimp 22154/B & & & \\
& & & & & \\
\hline
\end{tabular}


(JE)

\begin{tabular}{llllll}
\hline Colura cylindrica & Panama & $\begin{array}{l}\text { Schäfer-Verwimp \& } \\
\text { Verwimp 30741 (JE) }\end{array}$ & JX470973 & JX470984 & JX470996 \\
& & & & \\
\hline $\begin{array}{l}\text { Colura digitalis } \\
\text { (Mitt.) Steph. }\end{array}$ & La Réunion & $\begin{array}{l}\text { Schäfer-Verwimp \& } \\
\text { Verwimp 20134 (JE) }\end{array}$ & & JX470988 & JX471000 \\
\hline $\begin{array}{l}\text { Colura } \\
\text { imperfecta }\end{array}$ & Fiji Isls. & Pócs 03261/BA & DQ238566 & DQ238585 & DQ987305 \\
$\begin{array}{lllll}\text { Steph. } \\
\text { Colura }\end{array}$ & & (GOET) & & & \\
imperfecta & Guinea & (JE) & & & \\
& & & & & \\
\hline $\begin{array}{l}\text { Colura inflata } \\
\text { K.I. Goebel }\end{array}$ & Malaysia & Schäfer-Verwimp \& & JX470968 & JX470979 & JX470991 \\
& & Verwimp 19010/A & & & \\
& & SE) & & & \\
\hline
\end{tabular}

\begin{tabular}{llllll}
\hline Colura & Ecuador, & Schäfer-Verwimp \& & JX470974 & JX470985 & JX470997 \\
ornithocephala & Azuay & Nebel 32854 (JE) & & & \\
Herzog & & & & & \\
& & & & & \\
\hline
\end{tabular}

\begin{tabular}{llllll}
\hline $\begin{array}{l}\text { Colura } \\
\text { ornithocephala }\end{array}$ & $\begin{array}{l}\text { Ecuador, } \\
\text { Carchi }\end{array}$ & $\begin{array}{l}\text { Schäfer-Verwimp et } \\
\text { al. 24391/A (JE) }\end{array}$ & JX470975 & JX470986 & JX470998 \\
& & & & \\
\hline $\begin{array}{l}\text { Colura } \\
\text { rhynchophora }\end{array}$ & Dominica & $\begin{array}{l}\text { Schäfer-Verwimp \& } \\
\text { Verwimp 17755 (JE) }\end{array}$ & JX470976 & JX470987 & JX470999 \\
& & & &
\end{tabular}

Jovet-Ast

\begin{tabular}{llllll}
\hline $\begin{array}{l}\text { Colura } \\
\text { tenuicornis }\end{array}$ & $\begin{array}{l}\text { Dominican } \\
\text { Republic }\end{array}$ & $\begin{array}{l}\text { Schäfer-Verwimp \& } \\
\text { Verwimp 27039 (JE) }\end{array}$ & JX470967 & JX470978 & JX470990 \\
$\begin{array}{l}\text { (A. Evans) } \\
\text { Steph. }\end{array}$ & & & & \\
\hline
\end{tabular}


\begin{tabular}{llllll}
\hline Colura tortifolia & Ecuador & Wilson et al. 04-12 & DQ983671 & DQ987440 & DQ987338
\end{tabular}

(Nees \& Mont.) (GOET)

Trevis.

\begin{tabular}{llllll}
\hline Colura tortifolia & Guadeloupe & Schäfer-Verwimp \& & JX470972 & JX470983 & JX470995 \\
& Verwimp 22441/C & & & \\
& (JE) & & \\
& & & &
\end{tabular}

\begin{tabular}{llllll}
\hline Macrocolura & Dominica & Schäfer-Verwimp \& & DQ983707 & DQ987466 & DQ987367 \\
sagittistipula & & Verwimp 18014 & & & \\
(Spruce) R.M. & & (GOET) & & \\
Schust. & & & & & \\
\end{tabular}

\begin{tabular}{llllll}
\hline $\begin{array}{l}\text { Myriocolea } \\
\text { irrorata Spruce }\end{array}$ & Ecuador & $\begin{array}{l}\text { Gradstein 10033 } \\
\text { (GOET) }\end{array}$ & AY548072 & DQ238584 & DQ987279 \\
\hline $\begin{array}{l}\text { Myriocolea } \\
\text { irrorata }\end{array}$ & Ecuador & Heinrichs et al. 4497 & - & - & \\
& & & & JX471001 & \\
\hline
\end{tabular}

TABLE 2. Distribution of constant and phylogenetically informative sites for aligned positions of the three genomic regions.

\begin{tabular}{lcccc}
\hline & $r b c L$ & $t r n L-F$ & ITS1-5.8S-ITS2 & Total \\
\hline Number of sites in matrix & 935 & 431 & 955 & 2,321 \\
\hline constant & 823 & 324 & 540 & 1,687 \\
\hline autapomorphic & 42 & 34 & 90 & 166 \\
\hline parsimony informative & 70 & 73 & 325 & 468 \\
& & & & \\
\hline
\end{tabular}




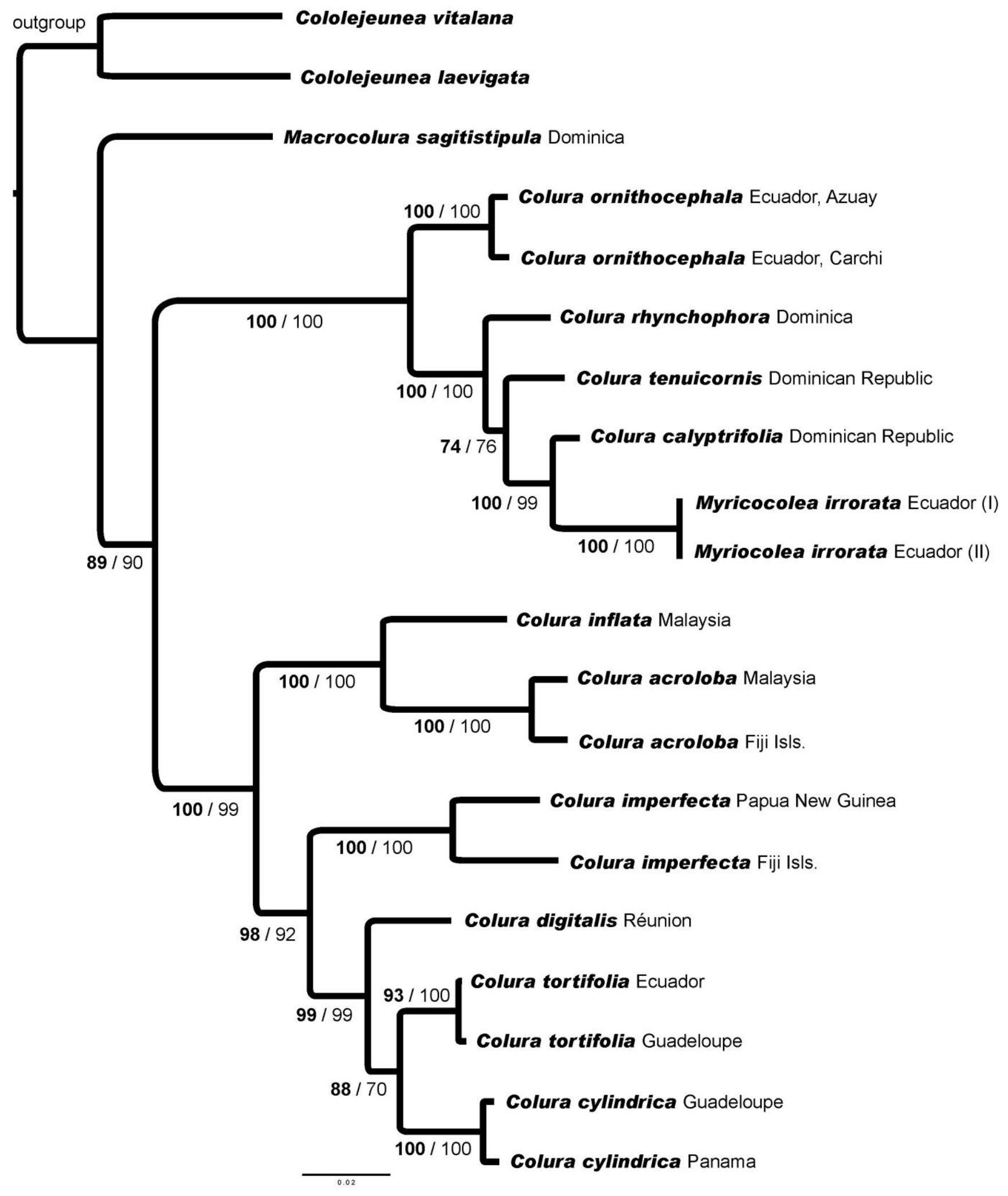

FIGURE 1. Single most likely tree ( $\mathrm{In}=-9,559.44384)$ derived from a cp DNA rbcL-trnL-F - nrITS dataset. ML bootstrap values (bold) and MP bootstrap values (not bold) are indicated at branches. Two accessions of Myriocolea irrorata are nested in a robust subclade of Colura, and are placed sister to the Colura-generitype, C. calyptrifolia. 


\section{Appendix 5 \\ Sphaerolejeunea (Lejeuneaceae, Porellales) is a synonym of Lejeunea}

Jochen Heinrichs, Shanshan Dong, Kathrin Feldberg, Alfons Schäfer-Verwimp, Alexander R. Schmidt

Published in Phytotaxa, 2012, 69, 7-15. 


\section{Abstract}

Phylogenetic analyses of a three marker dataset of Lejeuneaceae (chloroplast genome $r b c \mathrm{~L}$ gene and $t r n \mathrm{~L}-\mathrm{F}$ region, and nuclear ribosomal ITS1-5.8S-ITS-2 region) show the presence of the monospecific genus Sphaerolejeunea in a robust subclade of Lejeunea. We treat Sphaerolejeunea as a synonym of Lejeunea, and propose a new name for Sphaerolejeunea umbilicata, Lejeunea drehwaldii.

Key words: Jungermanniopsida, liverwort, Neotropics, taxonomy

\section{Introduction}

Spruce (1884) in his outstanding treatment of Lejeuneaceae accepted only two genera, Myriocolea Spruce (1884: 305) and Lejeunea Libert (1820: 372), the latter subdivided in 39 subgenera. Most of them were elevated to genus rank by Schiffner (1893), and additional genera were newly established (e.g., Piippo 1986, Schuster 1994, Reiner-Drehwald 2000), leading to the recognition of about 90 genera in Lejeuneaceae (Gradstein et al. 2003). More than sixty of them include species placed in Lejeunea by Spruce (Gradstein et al. 2004).

However, after an era in which numerous genera were separated from Lejeunea, the recent trend goes to a wider genus concept. Several genera were recently synoymized with Lejeunea, namely Crossotolejeunea(Spruce 1884: 161) Schiffner (1893: 127) and Dactylolejeunea Schuster (1971: 341) (Reiner-Drehwald \& Goda 2000), Amphilejeunea Schuster (1978: 431) and Cryptogynolejeunea Schuster (1994: 215) (Reiner-Drehwald 2005a), Dicladolejeunea Schuster (1994: 220) (Reiner-Drehwald 2005b), Echinocolea Schuster (1963: 125) (Ilkiu-Borges 2005), Neopotamolejeunea Reiner-Drehwald (2000: 449) (Gradstein \& Reiner-Drehwald 2007), Inflatolejeunea Arnell (1953: 173), Macrolejeunea (Spruce) Schiffner in Engler \& Prantl (1893: 118) (Reiner-Drehwald \& Schäfer-Verwimp 2008), and Amblyolejeunea Jovet-Ast (1948: 24) (Zhu \& Cheng 2008).

Sphaerolejeunea Herzog (1938: 88) was set up for a single species, S. umbilicata Herzog (1938: 88) and based on a single specimen collected by E.P. Killip in 1922 in the 
Andes of Colombia. This epiphyllous species stands out by leaf lobes bordered by several rows of hyaline cells, basally leafless gynoecial branches and perianths lacking both a beak and keels. These perianths hardly exceed the surrounding vegetative leaves (Herzog 1938) and open in an umbilicus at their dorsal side (Reiner-Drehwald \& Drehwald 2002).

In 2001 U. Drehwald discovered a second locality of Sphaerolejeunea umbilicata in the Andes of northern Peru. The related herbarium specimen allowed for a detailed morphological investigation of the species and the proposal of a sister relationship of Sphaerolejeunea and Lejeunea (Reiner-Drehwald \& Drehwald 2002).

In the framework of a molecular phylogenetic study of Lejeunea (Dong et al. in prep.) we sequenced three molecular markers of Sphaerolejeunea, and included the sequences in a large alignment of Lejeuneaceae. Our phylogenetic analyses show that Sphaerolejeunea forms a lineage within Lejeunea. Accordingly, we transfer Sphaerolejeunea umbilicata to Lejeunea, and propose a nomen novum since the taxon Lejeunea umbilicata(Nees 1830: 42) Nees, Lindenberg \& Gottsche in Meyen (1843: 472) blocks a new combination.

\section{Materials and methods}

\section{Taxa studied, DNA extraction, PCR amplification and sequencing}

Plant tissue was isolated from a herbarium collection of Sphaerolejeunea umbilicata (Peru, Drehwald 10014, JE). Total genomic DNA was purified using Invisorb Spin Plant Mini Kit (Invitek, Berlin, Germany) prior to amplification. Protocols for PCR were carried out as described in previous publications: chloroplast genome $r b c \mathrm{~L}$ gene and $t r n \mathrm{~L}-\mathrm{F}$ region from Gradstein et al. (2006), and nuclear ribosomal ITS1-5.8S-ITS-2 region from Hartmann et al. (2006). Bidirectional sequences were generated using a MegaBACE 1000 automated sequencing machine using DYEnamic ET Primer DNA Sequencing Reagent (Amersham Biosciences, Little Chalfont, UK). Sequencing primers were those used for PCR. 
First we compared the new Sphaerolejeunea sequences with GenBank sequences using the BLASTN program (Altschul et al. 1990). These BLAST searches pointed to close relationships of Sphaerolejeunea and Lejeuneeae. Accordingly we compiled a Lejeuneeae ingroup dataset based on Wilson et al. (2007) using Genbank sequences (http://www.ncbi.nlm.nih.gov/genbank/). Fourteen representatives of Brachiolejeuneeae and Ptychanthoideae were chosen as outgroup. The related sequences came also from Genbank (Table 1).

\section{Phylogenetic analyses}

All sequences were aligned manually in Bioedit version 7.0.5.2 (Hall 1999). Ambiguous positions were excluded from all alignments. Lacking parts of $r b c L-$ sequences were coded as " $N$ " ( $A, C, G$ or $T$ ), lacking parts of other markers as unknown sequence stretches. Maximum parsimony (MP) analyses were carried out with PAUP* version 4.0b10 (Swofford 2000). MP heuristic searches were conducted with the following options implemented: heuristic search mode, 500 random-addition-sequence replicates, tree bisection-reconnection (TBR) branch swapping, MULTrees option on, and collapse zero-length branches off. All characters were treated as equally weighted and unordered. Where more than one most parsimonious tree was found, trees were summarized in a strict consensus tree.

Non-parametric bootstrapping values (Felsenstein 1985) were generated as heuristic searches with 500 replicates, each with ten random-addition replicates. Bootstrap percentage values (BPV) $\geq 70$ were regarded as good support (Hillis and Bull 1983). The individual marker sets and the combined chloroplast DNA dataset vs nrITS dataset were first analysed separately to check for incongruence. The strict consensus trees of the non-parametric bootstrap analyses were compared by eye to identify conflicting nodes supported by at least 70\% (Mason-Gamer and Kellog 1996). The trees gave no evidence of incongruence. Hence the datasets were combined.

jModeltest 0.1 (Posada 2008) was used to select models of evolution for maximum likelihood (ML) analyses of the three molecular markers. In all cases, a General Time 
Reversible (GTR) model (Tavaré 1986) was chosen with proportion of invariable characters (I) and among-site rate heterogeneity modelled as discrete gamma distribution with four rate categories, and its estimated parameters (Г) (Goldman 1993). Models for the rbcL-partition, the trnL-F partition and the nrITS partition were implemented in the program GARLI version 2.0 (Zwickl, 2006). Subsequently the datasets were combined and $\mathrm{ML}$ trees were generated. All GARLI analyses were performed with the default settings and several times repeated. The default setting of GARLI was also employed to calculate bootstrap values for ML analyses based on 200 bootstrap replicates.

\section{Results}

Seven hundred and thirteen of the 2086 investigated characters were parsimony informative, 251 variable but parsimony uninformative, and 1122 constant. The MP analysis resulted in 45 equally parsimonious trees with a length of 4852 steps, a consistency index $(\mathrm{Cl})$ of 0.34 and a retention index $(\mathrm{RI})$ of 0.58 . The strict consensus tree is depicted in Figure 1. Most deep nodes did not get BPVs. A derived clade with Harpalejeunea grandistipula Schuster (1999: 290), Pluvianthus squarrosus (Stephani 1896: 130) Schuster \& Schäfer-Verwimp in Schuster (1994: 213) and 15 representatives of Lejeunea had a BPV of 100, the Lejeuneaclade a BPV of 81. Spaerolejeunea umbilicata was nested in a robust subclade of Lejeunea that achieved a BPV of 100.

The Garli analysis resulted in a ML topology ( $I n=-24516.7446$, Figure 2) that resembles the MP strict consensus tree. Again Sphaerolejeunea is nested in a derived subclade of Lejeunea with a BPV of 100.

\section{Discussion and taxonomic treatment}

Reiner-Drehwald and Drehwald (2002) in their detailed morphological treatment of Sphaerolejeunea listed numerous analogies with Lejeunea including the presence of shoots with a hyalodermis, two cells wide ventral merophytes, proximal hyaline papillae, lejeuneoid innovations, inflated perianths without keels, capsule wall apices with a quadrate cell in the outer layer, and "butterfly-shaped" cell structures in the basal half of 
the capsule walls. The above authors however pointed out that Sphaerolejeunea differs from Lejeunaby the development of a second lobule tooth, leaves bordered by hyaline cells [but also present in Neopotamolejeunea, another synonym of Lejeunea (ReinerDrehwald 1999, Gradstein \& Reiner-Drehwald 2007)], beakless perianths being umbilicate on the dorsal side and valves with five marginal elaters lacking thickenings. Taking into account the morphological similarities Reiner-Drehwald \& Drehwald (2002) suggested that Sphaerolejeunea may represent the sister group of Lejeunea. However, our phylogenies (Figures 1,2) indicate that Sphaerolejeunea is nested in Lejeunea and that its morphological peculiarities represent autapomorphies of a Lejeunea species rather than of its sister lineage.

We therefore lower Sphaerolejeunea to a synonym of Lejeunea:

Lejeunea Libert (1820: 372)

= Sphaerolejeunea Herzog (1938: 88), syn. nov.

The taxon Lejeunea umbilicata (Nees 1830: 42) Nees, Lindenberg \& Gottsche in Meyen (1843: 472) blocks a transfer of Sphaerolejeunea umbilicata to Lejeunea. Accordingly, we propose a new name, as follows:

Lejeunea drehwaldii Heinrichs \& Schäf.-Verw., nom. nov. Replaced name:-Sphaerolejeunea umbilicataHerzog, Annales Bryologici 11: 88, 1938 (Herzog 1938). Holotype:-COLOMBIA, Cauca, Micay Valley, 1400-1800 m, 1922, Killip 7750 p.p. (JE). Blocking name:-Lejeunea umbilicata (Nees) Nees, Lindenberg \& Gottsche in Meyen 472, 1843 (Meyen 1843).

Etymology: We dedicate the new name to the bryologist and lichenologist Uwe Drehwald, Göttingen, who collected the DNA voucher of Sphaerolejeunea on which our study was based.

\section{Acknowledgements}

This study was supported by the Deutsche Forschungsgemeinschaft [HE 3584/4]. SD was supported by the China Scholarship Council (scholarship No. 2010697001). This is 
publication number 105 from the Courant Research Centre Geobiology that is funded by the German Initiative of Excellence.

\section{References}

Altschul, S.F., Gish, W., Miller, W., Myers, E.W. \& Lipman, D.J. (1990) Basic local alignment search tool. Journal of Molecular Biology 215: 403-410.

Arnell, S. (1953) Hepaticae collected in South Africa 1951. New and little known species II. Botaniska Notiser 106: 163-186.

Felsenstein, J. (1985) Confidence limits on phylogenies: an approach using the bootstrap. Evolution 39: 783-791.

Goldman, N. (1993) Statistical tests of models of DNA substitution. Journal of Molecular Evolution 36: 182-198.

Gradstein, S.R. \& Reiner-Drehwald, M.E. (2007) The status of Neopotamolejeunea (Lejeuneaceae) and description of a new species from Ecuador and southern Brazil. Systematic Botany 32: 487-492.

Gradstein, S.R., Reiner-Drehwald, M.E. \& Jost, L. (2004) The systematic position and distribution of Myriocolea irrorata (Lejeuneaceae), an endangered liverwort of the Ecuadorian Andes. Journal of the Hattori Botanical Laboratory 95: 235-248.

Gradstein, S.R., Reiner-Drehwald M.E. \& Schneider, H. (2003) A phylogenetic analysis of the genera of Lejeuneaceae (Hepaticae). Botanical Journal of the Linnean Society 143: 391-410.

Gradstein, S.R., Wilson, R., Ilkiu-Borges, A.L. \& Heinrichs, J. (2006) Phylogenetic relationships and neotenic evolution of Metzgeriopsis (Lejeuneaceae) based on chloroplast DNA sequences and morphology. Botanical Journal of the Linnean Society 151: 293-308. 
Hall, T.A. (1999) BIOEDIT: a user-friendly biological sequence alignment editor and analysis program for Windows 95/98/NT. Nucleic Acids Symposia Series 41: 95-98.

Hartmann, F.A., Wilson, R., Gradstein, S.R., Schneider, H. \& Heinrichs, J. (2006) Testing hypotheses on species delimitations and disjunctions in the liverwort Bryopteris (Jungermanniopsida: Lejeuneaceae). International Journal of Plant Sciences 167: 1205-1214.

Herzog, T. (1938) Sphaerolejeunea, eine neue Gattung der Lejeuneaceae Schizostipae. Annales Bryologici 11: 86-89.

Hillis, D.M. \& Bull J.J. (1993) An empirical test of bootstrapping as a method for assessing the confidence in phylogenetic analysis. Systematic Biology 42: 182-192.

Ilkiu-Borges, A.L. (2005) A taxonomic revision of Echinocolea. Nova Hedwigia 80: 45-71.

Jovet-Ast, S. (1948) Hépatiques des Antilles françaises récoltées par P. et V. Allorge en 1936. Revue Bryologique et Lichénologique 17: 24-34.

Libert, M. (1820) Sur un genre noveau d'Hépatiques, Lejeunia. Annales Generales des Sciences Physiques 6: 372-374.

Mason-Gamer, R.J. \& Kellogg, E.A. (1996) Testing for phylogenetic conflict among molecular data sets in the tribe Triticeae (Gramineae). Systematic Biology 45: 524545.

Meyen, F.J.F. (1843) Observationes Botanicas in itinere circum terram institutas. Opus posthumum. Sociorum Academiae curis suppletem. Novorum actorum Academiae Caesareae Leopoldino-Carolinae Naturae Curiosorum, v. 19, suppl. 1, 512 pp.

Nees, C.G.D. (1830) Enumeratio Plantarum Cryptogamicarum Javae [...]. Breslau, 
Sumptibus Grassii, Barthii et Soc., 86 pp.

Piippo, S. (1986) A monograph of the genera Lepidolejeunea and Luteolejeunea (Lejeuneaceae, Hepaticae). Acta Botanica Fennica 132: 1-69.

Posada, D. (2008) jModelTest: Phylogenetic model averaging. Molecular Biology and Evolution 25: 1253-1256.

Reiner-Drehwald, M.E. (1999) On Potamolejeunea polyantha (Mont.) E.Reiner \& Goda comb. nov. (Lejeuneaceae), a poorly known rheophytic liverwort from South America. Haussknechtia Beiheft 9: 299-306.

Reiner-Drehwald, M.E. (2000) On Potamolejeunea and Neopotamolejeunea gen. nov. (Lejeuneaceae, Hepaticae). Nova Hedwigia 71: 447-464.

Reiner-Drehwald, M.E. (2005a) On Amphilejeunea and Cryptogynolejeunea, two small genera of Lejeuneaceae, and two common Neotropical Lejeunea species. Nova Hedwigia 81: 395-411.

Reiner-Drehwald, M.E. (2005b) On Lejeunea rotundifolia and Dicladolejeunea (Lejeuneaceae, Jungermanniopsida). Systematic Botany 30: 687-692.

Reiner-Drehwald, M.E. \& Goda, A. (2000) Revision of the genus Crossotolejeunea (Lejeuneaceae, Hepaticae). Journal of the Hattori Botanical Laboratory 89: 1-54.

Reiner-Drehwald, M.E. \& Drehwald, U. (2002) Sphaerolejeunea umbilicata (Lejeuneaceae): a critically endangered epiphyllous liverwort of the Andes. The Bryologist 105: 422-430.

Reiner-Drehwald, M.E. \& Schäfer-Verwimp, A. (2008) On Inflatolejeunea, Lejeunea species with eplicate perianths and Lejeunea talamancensis sp. nov. from Costa Rica. Nova Hedwigia 87: 387-420. 
Schiffner, V. (1893) Hepaticae. In: Engler, A. \& Prantl, K., Die natürlichen Pflanzenfamilien 1. Engelmann, Leipzig, pp. 97-141.

Schuster, R.M. (1963) An annotated synopsis of the genera and subgenera of Lejeuneaceae. Beihefte zur Nova Hedwigia9: 1-203.

Schuster, R.M. (1971) Studies on Hepaticae, XLIX-LIII. New Lejeuneaceae from Dominica and Jamaica. Bulletin of the Torrey Botanical Club 97: 336-352.

Schuster, R.M. (1978) Studies on Venezuelan Hepaticae, II. Phytologia 39: 425-432.

Schuster, R.M. (1994) Studies on Lejeuneaceae, I. Preliminary studies on new genera and subgenera of Lejeuneaceae. Journal of the Hattori Botanical Laboratory 75: 211235.

Schuster, R.M. (1999) Harpalejeunea (Spr.) Schiffn. I: Studies on a new Andean species of Harpalejeunea. Journal of the Hattori Botanical Laboratory 87: 287-294.

Spruce, R.M. (1884) Hepaticae Amazonicae et Andinae. Tribus I: Jubuleae. Transactions and Proceedings of the Botanical Society of Edinburgh 15: 1-308.

Stephani, F. (1896) Hepaticarum species novae IX. Hedwigia 35: 73-140.

Swofford, D.L. (2000) PAUP*, phylogenetic analyses using parsimony ( ${ }^{*}$ and other methods), version 4.01b10. Sinauer Associates, Sunderland, Massachusetts.

Tavaré, S. (1986) Some probabalistic and statistical problems on the analysis of DNA sequences. Lectures on Mathematics in the Life Sciences 17: 57-86.

Wilson, R., Gradstein, S.R., Schneider, H. \& Heinrichs, J. (2007) Unravelling the phylogeny of Lejeuneaceae (Jungermanniopsida): evidence for four main lineages. 
Molecular Phylogenetics and Evolution 43: 270-282.

Zhu, R.L. \& Cheng, X.F. (2008) The status of Amblyolejeunea (Lejeuneaceae) from Ecuador and Guadeloupe. Systematic Botany 33: 617-620.

Zwickl, D.J. (2006) Genetic algorithm approaches for the phylogenetic analysis of large biological sequence datasets under the maximum likelihood criterion. GARLI version 2.0 available online at https://code.google.com/p/garli/. 
TABLE 1. Taxa used in the present study, including information about the origin of the studied material, voucher information, as well as GenBank accession numbers.

Taxon

Taxon

Voucher

Voucher

$r b c \mathrm{~L} \quad t r n \mathrm{~L}-\mathrm{F} \quad \mathrm{nrITS}$

Acanthocoleus javanicus

Bali, Schäfer-Verwimp

DQ983648

DQ987398

DQ987291

(Steph.) Kruijt 20817

Acrolejeunea fertilis (Reinw. Bali, Schäfer-Verwimp et al.) Schiffn. 17009

Anoplolejeunea conferta

Ecuador, Wilson et al. 04-

(C.F.W. Meissn. ex Spreng.) 08

A.Evans

Archilejeunea fuscescens

(Hampe ex Lehm.) Fulf.

Aureolejeunea aurifera

R.M.Schust.

Aureolejeunea fulva

R.M.Schust.

Aureolejeunea

quinquecarinata

R.M.Schust.

Bryopteris diffusa (Sw.)

Nees

Ceratolejeunea cornuta

(Lindenb.) Steph.

Ceratolejeunea cf.
Costa Rica, Bernecker 9753

Costa Rica, Holz CR00-

AY548082

DQ238569

DQ987272 696

Brazil, Costa \& Gradstein

AY548070

DQ987269 3849

Ecuador, Schäfer-Verwimp

DQ983658

DQ987450

DQ987350 23299/A

Bolivia, Acebey \&

AY548085 AM237147 AM237095

Villavicencio 855

Bolivia, Drehwald 4739

AY548088 DQ238570

DQ987257

Ecuador, Wilson et al. 04- DQ983662 DQ987442 DQ987340 
guianensis 15

Cheilolejeunea acutangula

Mexico, Gradstein \&

DQ983664 DQ987386 DQ987270

(Nees) Grolle

Velasquez s.n.

Lejeunea lamacerina

Canary Islands, Schäfer-

DQ983694

DQ987358

(Steph.) Schiffn.

Verwimp 24616

Lejeunea mimula Hürl.

Bali, Schäfer-Verwimp

AY548104 DQ238580 DQ987261 20930

Lejeunea pallescens Mitt.

Ecuador, Schäfer-Verwimp

AY548068 DQ238576 DQ987292 23533

Lejeunea paucidentata

Dominica, Schäfer-

DQ983695 DQ987447 $\quad$ DQ987345

(Steph.) Grolle

Verwimp 17737

Lejeunea cf. pterigonia

Bolivia, Gradstein 9964

DQ983732 DQ987429

DQ987325

(Lehm. \& Lindenb.) Mont.

Lejeunea sp. I

Ecuador, Gradstein \& Jost

DQ983712 DQ987416

DQ987312 10063

Lejeunea sp. II

Ecuador, Gradstein 10172

DQ983734

DQ987410

DQ987304

Lepidolejeunea bidentula

China, Koponen et al.

AY125936 AY144476

AY125340

(J.B. Jack \& Steph.) R.M.

51525

Schust.

Lepidolejeunea eluta (Nees) Bolivia, Drehwald 4833

DQ983696 DQ987379 DQ987257 R.M.Schust.

Lepidolejeunea integristipula Fiji, Pócs 03307/AC

DQ983697 DQ987417 DQ987313 (Jack \& Steph.) R.M.Schust.

Lopholejeunea eulopha

(Tayl.) Schiffn.
Australia, Pócs \&

Streimann $9987 / \mathrm{H} 1$

AY548067 DQ987381 DQ987262 
Luteolejeunea herzogii (Buchloh) Piippo

Macrocolura sagittistipula (Spruce) R.M.Schust.

Marchesinia robusta (Mitt.) Schiffn.

Mastigolejeunea auriculata (Wilson \& W.J.Hooker)

Schiffn.

Myriocoleopsis gymnocolea (Steph.) M.E. Reiner \& Gradst.

Neurolejeunea breutelii

(Gottsche) A.Evans

Omphalanthus filiformis Nees

Omphalanthus ovalis

(Lindenb. \& Gottsche)

Gradst.

Physantholejeunea portoricensis (Hampe \& Gottsche) R.M.Schust.

Pluvianthus squarrosus (Steph.) R.M.Schust. \& Schäfer-Verwimp

Ptychanthus striatus (Lehm. Java, Gradstein 10215

Dominica, Schäfer-

Verwimp 18014 05 10020 14740 23543 07

Guadeloupe, SchäferVerwimp 22615 13376 $\begin{array}{lll}\text { DQ983706 } & \text { DQ987467 } & \text { DQ987368 }\end{array}$ Verwimp \& Holz 0294/B

DQ983707 DQ987466 DQ987367

Ecuador, Wilson et al. 04-

DQ983710 DQ987436

DQ987332

Bolivia, Churchill 21275

AY548070 DQ987385 DQ987268

Ecuador, Gradstein et al.

DQ238568

DQ238583

DQ987277

Brazil, Schäfer-Verwimp

DQ983714 DQ987405 DQ987299

Ecuador, Schäfer-Verwimp

DQ983716 DQ987393

DQ987283

Ecuador, Wilson et al. 04-

DQ983717

DQ987334

DQ983719 DQ987448 DQ987346

Brazil, Schäfer-Verwimp

DQ983720 DQ987446

DQ987344 
\& Lindenb.) Nees

Pycnolejeunea densistipula

Ecuador, Schäfer-Verwimp

AY548075

DQ987400

DQ987294

(Lehm. \& Lindenb.) Steph. 23368

Rectolejeunea berteroana

Guadeloupe, Schäfer-

DQ983724 DQ987444 $\quad$ DQ987342

(Gottsche) A. Evans

Verwimp 22245/A

Schiffneriolejeunea nymannii

Malaysia, Gradstein et al.

DQ983725 DQ987424

DQ987320

(Steph.) Gradst. \& Terken 10321

Siphonolejeunea

Australia, Pócs \& Brown

DQ983726

DQ987452

DQ987352

elegantissima (Steph.)

0026/AA

Grolle

Sphaerolejeunea umbilicata

Ecuador, Drehwald 10014

HE995781 HE995782

HE995783

Herzog

Spruceanthus thozetianus

Australia, Pócs 01107/M

AM384877

DQ987460

DQ987362

(Gottsche \& F. v. Müll.) B.

Thiers

Thysananthus spathulistipus

Bali, Schäfer-Verwimp

DQ983739 DQ987392 DQ987282 (Reinw. et al.) Lindenb. 20790

Xylolejeunea crenata (Nees

Brazil, Schäfer-Verwimp

DQ983740

DQ987443

DQ987341

\& Mont.) X.-L. He \& Grolle 11225 


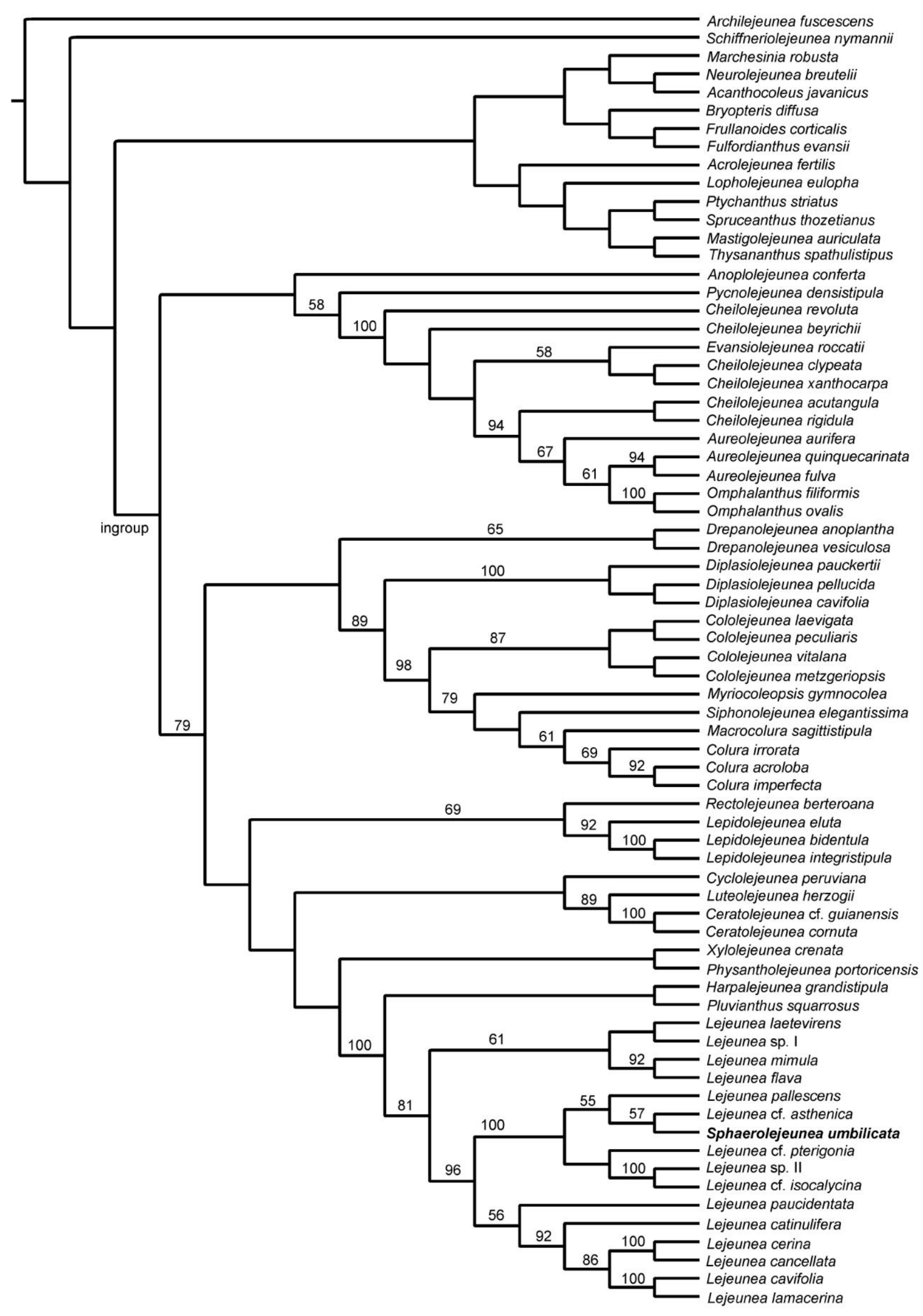

FIGURE 1. Strict consensus of 45 equally parsimonious trees based on the combined nrITS- chloroplast DNA rbcL - trnL-F dataset with bootstrap percentage values at branches. Sphaerolejeunea is nested in a robust subclade of Lejeunea. 
Archilejeunea fuscescens

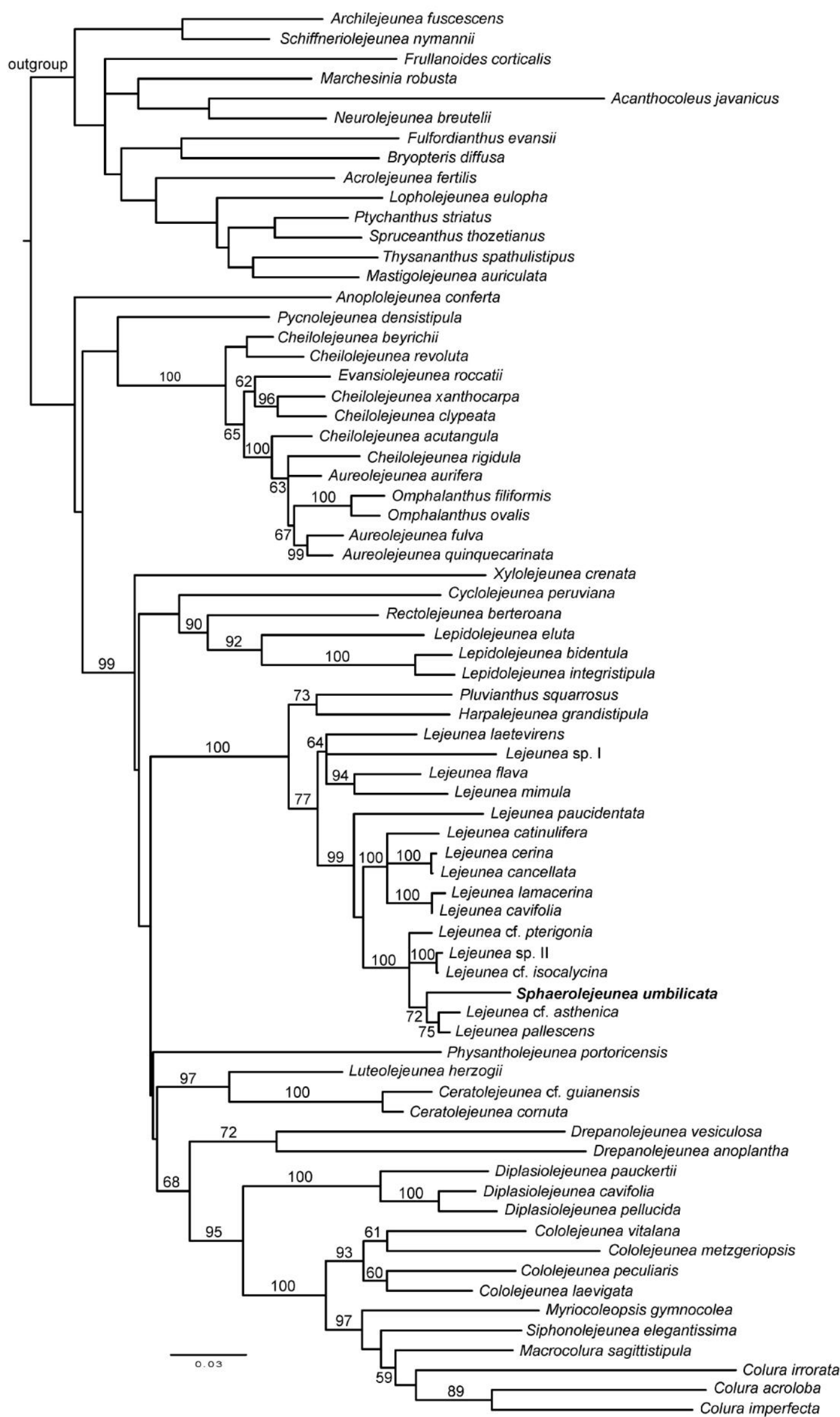

FIGURE 2. Phylogram generated in a maximum likelihood analysis of the combined dataset. Bootstrap values are indicated at branches. 


\section{Appendix 6}

\section{The Bromeliaceae tank dweller Bromeliophila (Lejeuneaceae, Porellales) is a member of the Cyclolejeunea-Prionolejeunea clade}

Jochen Heinrichs, Aleksandra Czumaj, Shanshan Dong, Armin Scheben, Alfons

Schäfer-Verwimp, Denilson F. Peralta, Kathrin Feldberg, Alexander R. Schmidt, Harald Schneider

Published in Plant Systematics and Evolution 2014, 300: 63-73 


\section{Abstract}

The Neotropical genus Bromeliophila includes two species that grow exclusively in the water-filled leaf axils of Bromeliaceae. Phylogenetic analyses of a three marker dataset (chloroplast genome $r b c \mathrm{~L}$ gene and $t r n \mathrm{~L}-\mathrm{F}$ region, and nuclear ribosomal ITS1-5.8S-ITS2 region) confirmed the monophyly of Bromeliophila and provided evidence for a sister relationship of Bromeliophila and Prionolejeunea; this clade is in turn sister to Cyclolejeunea. Despite remarkable morphological similarities, Bromeliophila is not closely related to Lejeunea and its close relatives Harpalejeunea and Microlejeunea. Based on the molecular topology and morphological evidence, Cyclolejeunea is subdivided in subgenus Cyclolejeunea and the monospecific subgenera Hyalolejeunea and Nephrolejeunea. Genetic relationships among multiple accessions of the same species support currently accepted morphological-typological species concepts.

Keywords: Classification, Epiphyte, Epiphylly, Jungermanniopsida, Liverwort

\section{Introduction}

Lejeuneaceae are very abundant in the humid tropics, making up a large part of the local epiphytic, and especially epiphyllous, liverwort diversity (Wilson et al. 2007). With some 1,000 species in 68 currently accepted genera, they are the largest family of liverworts (Gradstein et al. 2003, 2013). Generic limits in Lejeuneaceae, however, often remain controversial (Schuster 1994).

Recent molecular phylogenetic studies of Lejeuneaceae have led to a considerable reduction of generic names and the establishment of morphologically variable, speciesrich taxonomic units (Gradstein et al. 2006; Wilson et al. 2007; Heinrichs et al.2012a, b; Dong et al. 2013; Ye et al. 2013). This trend is rather consistent with the trend towards the acceptance of larger genera in all lineages of land plants (Humphreys and Linder 2009). A good example in this regard is Lejeunea Lib. whose current synonymy includes more than a dozen generic names (Heinrichs et al. 2012a; Ye et al. 2013).

Bromeliophila R.M. Schust. was set up for Peltolejeunea natans Steph., a Brazilian endemic, growing exclusively in the tanks of Bromeliaceae (Schuster 1994). The lower 
parts of the gametophytic shoots are often submerged and only the upper parts are located above the water. Schuster (1994) considered Bromeliophila and Lejeunea to be closely related, a view reiterated by Gradstein (1997), who deemed the generic status "critical". However, a second Neotropical species, Bromeliophila helenae Gradst., was introduced without further confirmation of the generic classification. The morphological similarities between Bromeliophila and Lejeunea are illustrated by the classification of Grolle (1985), who transferred Peltolejeunea natans to Lejeunea, renaming it to Lejeunea natans (Steph.) Grolle.

In the framework of a comprehensive molecular phylogenetic-taxonomic study of Lejeuneaceae (Hartmann et al. 2006; Wilson et al. 2007; Dong et al. 2012, 2013; Heinrichs et al. 2009, 2012a, b; Yu et al. 2013) we sequenced chloroplast and nuclear markers of both species of Bromeliophila. Here, we aim to confirm the monophyly of Bromeliophila and provide evidence for a close relationship of Bromeliophila with Prionolejeunea (Spruce) Schiffn. rather than with Lejeunea.

\section{Materials and methods}

\section{Taxa studied, DNA extraction, PCR amplification and sequencing}

Plant tissue was isolated from herbarium collections of the two known species of Bromeliophila, six species of Cyclolejeunea A. Evans, and twelve species of Prionolejeunea (Table 1). Total genomic DNA was purified using Invisorb Spin Plant Mini Kit (Stratec Molecular, Berlin, Germany) prior to amplification. Protocols for PCR were carried out as described in previous publications: chloroplast genome $r b c \mathrm{~L}$ gene and trnL-F region from Gradstein et al. (2006), and nuclear ribosomal ITS1-5.8S-ITS2 region from Hartmann et al. (2006). Bidirectional sequences were generated using a MegaBACE 1,000 automated sequencing machine using DYEnamic ET Primer DNA Sequencing Reagent (Amersham Biosciences, Little Chalfont, UK). Sequencing primers were those used for PCR. Newly generated sequences were assembled and edited using SeqAssem (Hepperle 2004).

We compared our new sequences with GenBank sequences using the BLASTN program (Altschul et al. 1990). The BLASTN searches confirmed an affiliation of the 
studied taxa to Lejeuneeae. Accordingly, we compiled a Lejeuneeae ingroup dataset based on Dong et al. (2013) and Wilson et al. (2007) using our new sequences as well as Genbank sequences (http://www.ncbi.nlm.nih.gov/genbank/). Two representatives of Ptychanthoideae were chosen as outgroup according to the topologies presented in Wilson et al. (2007). The related sequences were also obtained from Genbank (Table 1). Phylogenetic analyses of the Lejeuneeae dataset identified the closest relatives of Bromeliophila. Based on the outcome of these analyses, we assembled a second dataset consisting of accessions of Bromeliophila, Cyclolejeunea, and Prionolejeunea as the ingroup and three species of Lepidolejeunea R.M. Schust. as the outgroup. Whenever possible we included multiple accessions of species to explore infraspecific genetic variation and to examine whether our phylogeny corresponds to morphologically circumscribed entities.

\section{Phylogenetic analyses}

All sequences were aligned manually in Bioedit version 7.0.5.2 (Hall 1999). Ambiguous positions were excluded from the alignments. Missing sequence stretches were coded as unknown. Bayesian inference of phylogeny was carried out with MrBayes 3.2.1 (Huelsenbeck and Ronquist 2001) on XSEDE via the Cipres Science Gateway (http://www.phylo.org/sub_sections/portal/). Maximum parsimony (MP) analyses were carried out with PAUP* version 4.0b10 (Swofford 2000). MP heuristic searches were conducted with the following options implemented: heuristic search mode, 1,000 random-addition-sequence replicates, tree bisection-reconnection branch swapping, MULTrees option on, and collapse zero-length branches off. All characters were treated as equally weighted and unordered. Where more than one most parsimonious tree was found, they were summarized in a strict consensus tree.

Non-parametric bootstrapping values (Felsenstein 1985) were generated as heuristic searches with 1,000 replicates, each with ten random-addition replicates. Rearrangements were restricted to one million per replicate. Bootstrap percentage values (BPV) $\geq 70 \%$ were regarded as good support (Hillis and Bull 1993). The individual marker sets and the combined chloroplast DNA dataset versus nrITS dataset were first analysed separately to check for incongruence. The strict consensus trees of 
the non-parametric bootstrap analyses were compared by eye to identify conflicting nodes supported by at least 70 \% (Mason-Gamer and Kellogg 1996). The trees gave no evidence of incongruence. Hence, the datasets were combined.

Bayesian searches were conducted using four simultaneous Markov chains over 25 million generations (heterogeneous model) and sampling every 2,500th generation. Tracer version 1.5 (Rambaut and Drummond 2003) was used to examine the parameters and determine the number of trees needed to reach stationarity (burn-in). Bayesian posterior probability (BPP) confidence values were generated from trees saved after this initial burn-in. Values were regarded as significant when BPP $\geq 0.95$ (Larget and Simon 1999).

\section{Results}

\section{Lejeuneeae dataset}

Of the 2,015 investigated characters, 1,321 were constant and 441 parsimony informative (see Table 2 for character state distributions within the single markers). The MP analysis yielded four equally parsimonious trees with a length of 1,940 steps, a consistency index $(\mathrm{Cl})$ of 0.53 and a retention index (RI) of 0.47 (Fig. 1). Bromeliophila natans and Prionolejeunea limpida Herzog formed a clade with a BPV $=100 \%$; this clade was placed sister to Cyclolejeunea luteola (Spruce) Grolle with a BPV $=100 \%$. The Bromeliophila-Cyclolejeunea-Prionolejeunea clade was found as sister to a clade made up by Rectolejeunea berteroana (Gottsche ex Steph.) A. Evans and Lepidolejeunea integristipula (J.B. Jack \& Steph.) R.M. Schust. in a moderately supported sister relationship (BPV = 67 \%). Lejeunea cavifolia (Ehrh.) Lindb., Harpalejeunea molleri (Steph.) Grolle and Microlejeunea africana Steph. were placed in an independent, polytomous clade with a BPV $=100 \%$.

\section{Bromeliophila-Cyclolejeunea-Prionolejeunea dataset}

Five hundred and thirty of the 2,291 investigated characters were parsimony informative, 211 unique to a single specimen and 1,550 constant (Table 2). The strict consensus tree of 156 equally parsimonious trees with a length of 1,715 steps, a 
consistency index $(\mathrm{Cl})$ of 0.6 and a retention index $(\mathrm{RI})$ of 0.84 is shown in Fig. 2 . Bromeliophila was sister to Prionolejeunea with a BPV $=100 \%$. The Bromeliophila clade $(\mathrm{BPV}=99 \%$ ) consisted of two accessions of $B$. natans from the states of São Paulo and Santa Catharina and a paratype of $B$. helenae from Dominica. The two $B$. natans accessions formed a sister relationship with a BPV of $100 \%$. The Prionolejeunea clade achieved a BPV $=99 \%$. One accession of $P$. grata (Gottsche) Schiffn. from Réunion was placed sister to a moderately supported Neotropical Prionolejeunea clade (BPV $=63 \%$ ). Multiple accessions of $P$. schlimiana (Gottsche) Steph. and $P$. scaberula (Spruce) Steph. formed monophyla. Three accessions of $P$. decora (Taylor) Steph. were placed in a polytomy with an accession of $P$. mucronata(Sande Lac.) Steph. (BPV = $67 \%$ ).

The Bromeliophila-Prionolejeunea clade was placed sister to the well-supported Cyclolejeunea clade (BPV $=100 \%$ ). Multiple accessions of all investigated Cyclolejeunea species formed monophyla with BPVs ranging from 85 to $100 \%$.Cyclolejeunea (subg. Nephrolejeunea Grolle) luteola was sister to the rest of the genus with a BPV $=55 \%$, followed by a clade with several accessions of $C$. (subg. Hyalolejeunea Grolle) accedens (Gottsche) A. Evans. Cyclolejeunea peruviana (Lehm. \& Lindenb.) A. Evans formed a well supported sister relationship (BPV = $99 \%$ ) with a clade including accessions of $C$. chitonia (Taylor) A. Evans, C. foliorum (Nees) Grolle and $C$. convexistipa (Lehm. \& Lindenb.) A. Evans ( $C$. subg. Cyclolejeunea). A sister relationship of $C$. chitonia and $C$. foliorum has a BPV $=98 \%$.

The topology derived from the Bayesian analysis (Fig. 3) resembles the MP strict consensus tree (Fig. 2). In contrast to the MP topology, Prionolejeunea aemula (Gottsche) A. Evans from Guadeloupe is placed sister to the rest of this genus but with a BPP value $<0.95$. Three accessions of $P$. decora form a monophyletic lineage with a $\mathrm{BPP}=1.00$. Cyclolejeunea luteola was sister to the rest of this genus with a BPP $=1.00$. The crown groups of most Cyclolejeunea species showed intra-species relationships with BPP $>0.95$.

\section{Discussion}




\section{Systematic position of Bromeliophila}

Small or even monospecific genera of Lejeuneeae often prove to be nested in larger entities when molecular data are taken into account, e.g. Metzgeriopsis K.I. Goebel in Cololejeunea (Spruce) Schiffn. (Gradstein et al. 2006), Myriocolea Spruce in Colura(Dumort.) Dumort. (Heinrichs et al. 2012b) and Oryzolejeunea (R.M. Schust.) R.M. Schust. as well as Sphaerolejeunea Herzog in Lejeunea (Heinrichs et al. 2012a; Ye et al. 2013). We expected a similar result for Bromeliophila since several authors proposed a close relationship of Bromeliophila and Lejeunea based on their extensive morphological overlap (Schuster 1994; Gradstein 1997, 2013). In addition, some authors treated the generitype Peltolejeunea natans as an element of Lejeunea (Grolle 1985). Bromeliophila and Lejeunea share a soft texture, greenish or yellowish-green color, lejeuneoid gynoecial innovations, 2-cells broad ventral merophytes, bifid underleaves and noncompressed, equally 5-keeled perianths. However, despite these similarities, Bromeliophila is not closely related to Lejeunea but an element of the PrionolejeuneaCyclolejeunea clade (Fig. 1). The close relationship of Prionolejeunea and Cyclolejeunea is morphologically well founded since both genera share 2-keeled perianths, denticulate leaf margins and vegetative branches of the Lejeunea-type (Schuster 1992). This sister relationship has furthermore been supported by DNA sequence data (llkiu-Borges 2005). In stark contrast, Bromeliophila has entire leaf margins and longly stipitate 5-keeled perianths of which each is double-winged (Fig. 4; Schuster 1994; Gradstein 1997). Despite these differences in leaf margin and perianth structure, nuclear as well as chloroplast sequence data recovered a sister relationship of Bromeliophila and Prionolejeunea. This relationship is consistent with the shared occurrence of lejeuneoid gynoecial innovations and lack of ocelli (Schuster 1994; Bernecker-Lücking 1998). Cyclolejeunea on the other hand has pycnolejeuneoid gynoecial innovations (Grolle 1984) and-with the exception of $C$. accedens-ocelli.

\section{Classification of Cyclolejeunea and Prionolejeunea}

The species lineages of Prionolejeunea originate from a largely polytomous backbone (Fig. 3), hence a classification into supraspecific entities is unwarranted. In contrast, the Cyclolejeunea crown group splits into several well-separated lineages that can be 
recognized by combinations of morphological character states (Grolle 1984). Cyclolejeunea subg. Nephrolejeunea includes the only species with ovate to elongate gemmae with a median constriction, C. luteola (Bernecker-Lücking 1998), whereas C. subg. Hyalolejeunea includes $C$. accedens, the only species lacking ocelli. Cyclolejeunea subg. Cyclolejeunea comprises the species with ocelli and rounded gemmae ( $C$. chitonia, C. convexistipa, C. foliorum, C. peruvianum).

\section{Ecology of the Bromeliophila--Cyclolejeunea-Prionolejeunea clade}

Cyclolejeunea and Prionolejeunea are epiphyllous or corticolous epiphytes in moist lowland and lower montane rainforests. They do not show an obvious preference to particular groups of angiosperms. In contrast, Bromeliophila is so far known only as an epiphyll, growing exclusively in the water-filled leaf axils of Bromeliaceae (Gradstein et al. 2001; Benavides and Callejas 2004). Due to this peculiar habitat, Bromeliophila stands are likely better supplied with nutrients than Cyclolejeunea and Prionolejeunea populations; however, the humid and rather nutrient-rich habitat cannot explain the deviant perianth structure of Bromeliophila. It is still somewhat unclear how Bromeliophila builds up local populations; however, the lack of propagules indicates that range formation is a result of spore dispersal. Given the unique habitat, Bromeliophila spores may be not only distributed through wind currents but also through animals, such as amphibians and insects, that are dependent on the watertight compartments formed by leaf bases of bromeliads. It has been shown that frogs and snakes can act as dispersal agents for limnetic invertebrates endemic to the bromelioid tanks (Lopez et al. 1999, 2005).

Bromeliophila and Cyclolejeunea are Neotropical genera whereas Prionolejeunea occurs in tropical America and Africa (Ilkiu-Borges 2005). The limited genetic divergence among species of the Prionolejeunea crown group (Fig. 3) indicates that the AfricanAmerican disjunctions are the result of dispersal events rather than vicariance. Similar patterns have been reported for other genera of liverworts (Heinrichs et al. 2005; Hartmann et al. 2006; Feldberg et al. 2007) and also other land plants such as ferns (Janssen et al. 2007; Rouhan et al. 2012) and bromelioids (Givnish et al. 2004). 


\section{Circumscription of species}

Multiple accessions of morphologically-typologically circumscribed species form monophyletic lineages (Figs. 2, 3), indicating congruence of morphologicallytypologically inferred and phylogenetically inferred species. In a study on Cyclolejeunea, Bernecker-Lücking (1998) recovered considerable infraspecific variation of characters of the sterile gametophyte. This variation/plasticity may reflect at least partly adaptation to environmental conditions. Several Cyclolejeunea species show a genetic differentiation among accessions, providing some evidence for the accumulation of genetic diversity, which may coincide with the mentioned morphological variation. An extension of the sampling is necessary to discover morphological disparity or geographical patterns within the currently accepted Cyclolejeunea species. Similar results have been reported for several genera of leafy liverworts such as Diplasiolejeunea (Spruce) Schiffn. (Dong et al. 2012), Frullania Raddi (Ramaiya et al. 2010), Marchesinia Gray (Heinrichs et al. 2009), and Porella L. (Heinrichs et al. 2011). Morphologically cryptic or semicryptic biologically relevant entities have been recovered in the majority of species complexes of liverworts that were studied exhaustively.

The infraspecific variation of Bromeliophila and Prionolejeunea species is comparatively low. Unfortunately, we were not able to sequence multiple accessions of Bromeliophila helenae. This species is considered to be morphologically variable and has a disjunct range with stands in the Lesser Antilles, Colombia and the Guyana Highland of Venezuela (Benavides and Callejas 2004). Information on the internal molecular variation would allow for testing of the current species concept and a reconstruction of the formation of its range.

\section{Perspectives}

Our study provides evidence for a single origin of the obligate Bromeliaceae tank dwellers of Lejeuneaceae and clarifies their systematic position. The sister relationship of Prionolejeunea and Bromeliophila is proposed here for the first time, demonstrating the importance of molecular data for resolving relationships within Lejeuneaceae. Several genera with unclear taxonomic affinities need to be included in future studies,

e.g. Kymatolejeunea Grolle and Metalejeunea Grolle. These studies will allow for a 
classification of Lejeuneaceae in monophyletic entities and a reconstruction of their morphological evolution and range formation.

\section{Acknowledgments}

We are grateful to the directors and curators of the herbaria cited in the text for the loan of specimens and the permission for destructive sampling. This study was supported by the German Research Foundation [HE 3584/2 and 3584/4]. SD was supported by the China Scholarship Council (scholarship No. 2010697001). This is publication number 118 from the Courant Research Centre Geobiology that is funded by the German Initiative of Excellence.

\section{References}

Altschul SF, Gish W, Miller W, Myers EW, Lipman DJ (1990) Basic local alignment search tool. J Molec Biol 215:403-410

Benavides JC, Callejas R (2004) The discovery of Bromeliophila helenae Gradst. (Marchantiophyta, Lejeuneaceae) in the northern Andes of Colombia. Cryptog Bryol 25:169-174

Bernecker-Lücking A (1998) The genus Cyclolejeunea A. Evans (Hepaticae, Lejeuneaceae) in Costa Rica. Phyton 38:175-193

Dong S, Schäfer-Verwimp A, Meinecke P, Feldberg K, Bombosch A, Pócs T, Schmidt AR, Reitner J, Schneider H, Heinrichs J (2012) Tramps, narrow endemics and morphologically cryptic species in the epiphyllous liverwort Diplasiolejeunea. Molec Phylogen Evol 65:582-594

Dong S, Schäfer-Verwimp A, Pócs T, Feldberg K, Czumaj A, Schmidt AR, Schneider H, Heinrichs J (2013) Size doesn't matter-recircumscription of Microlejeunea based on molecular and morphological evidence. Phytotaxa 85:41-55

Feldberg K, Hentschel J, Wilson R, Rycroft DS, Glenny D, Heinrichs J (2007) Phylogenetic biogeography of the leafy liverwort Herbertus (Jungermanniales, 
Herbertaceae) based on nuclear and chloroplast DNA sequence data: correlation between genetic variation and geographical distribution. J Biogeogr 34:688-698

Felsenstein J (1985) Confidence limits on phylogenies: an approach using the bootstrap. Evolution 39:783-791

Givnish TJ, Millam KC, Evans TM, Hall JC, Pires JC, Berry PE, Sytsma KJ (2004) Ancient vicariance or recent long-distance dispersal? Inferences about phylogeny and South American-African disjunctions in Rapataceae and Bromeliaceae based on $n d h F$ sequence data. Int J PI Sci 54:S35-S54

Gradstein SR (1997) Bromeliophila helenae, a new species of Lejeuneaceae from the Neotropics. Cryptog Bryol Lichenol 18:217-221

Gradstein SR (2013) A classification of Lejeuneaceae (Marchantiophyta) based on molecular and morphological evidence. Phytotaxa 100:6-20

Gradstein SR, Churchill SP, Salazar-Allen N (2001) Guide to the bryophytes of tropical America. Mem New York Bot Gard 86:1-577

Gradstein SR, Reiner-Drehwald ME, Schneider H (2003) A phylogenetic analysis of the genera of Lejeunecaeae (Hepaticae). Bot J Linn Soc 143:391-410

Gradstein SR, Wilson R, Ilkiu-Borges AL, Heinrichs J (2006) Phylogenetic relationships and neotenic evolution of Metzgeriopsis (Lejeuneaceae) based on chloroplast DNA sequences and morphology. Bot J Linn Soc 151:293-308

Grolle R (1984) Zur Kenntnis der Lejeuneoideae in Cuba (1): Cyclolejeunea. Wiss Z Friedrich-Schiller-Univ Jena, Math-Naturwiss Reihe 33:759-764

Grolle R (1985) Miscellanea hepaticologia 231-240. J Hattori Bot Lab 58:197-202

Hall TA (1999) BIOEDIT: a user-friendly biological sequence alignment editor and analysis program for Windows 95/98/NT. Nucl Acids Symp Ser 41:95-98 
Hartmann FA, Wilson R, Gradstein SR, Schneider H, Heinrichs J (2006) Testing hypotheses on species delimitations and disjunctions in the liverwortBryopteris (Jungermanniopsida: Lejeuneaceae). Int J PI Sci 167:1205-1214

Heinrichs J, Lindner M, Gradstein SR, Groth H, Buchbender V, Solga A, Fischer E (2005) Origin and subdivision of Plagiochila (Jungermanniidae: Plagiochilaceae) in tropical Africa based on evidence from nuclear and chloroplast DNA sequences and morphology. Taxon 54:317-333

Heinrichs J, Klugmann F, Hentschel J, Schneider H (2009) DNA taxonomy, cryptic speciation and diversification of the Neotropical-African liverwort,Marchesinia brachiata (Lejeuneaceae, Porellales). Molec Phylogen Evol 53:113-121

Heinrichs J, Kreier HP, Feldberg K, Schmidt AR, Zhu R-L, Shaw B, Shaw AJ, Wissemann $V$ (2011) Formalizing morphologically cryptic biological entities: new insights from DNA-taxonomy, hybridization and biogeography in the leafy liverwort Porella platyphylla (Jungermanniopsida, Porellales). Amer J Bot 98:1252-1262

Heinrichs J, Dong S, Feldberg K, Schäfer-Verwimp A, Schmidt AR (2012a) Sphaerolejeunea (Lejeuneaceae, Porellales) is a synonym of Lejeunea. Phytotaxa 69:7-15

Heinrichs J, Dong S, Yu Y, Schäfer-Verwimp A, Pócs T, Feldberg K, Hentschel J, Schmidt AR, Schneider H (2012b) A 150-year old mystery solved: Transfer of the rheophytic endemic liverwort Myriocolea irrorata to Colura. Phytotaxa 66:55-64

Hepperle, D. (2004) SeqAssem@. A sequence analysis tool, contig assembler and trace data visualization tool for molecular sequences. Win32-Version. Distributed by the author via: http://www.sequentix.de

Hillis DM, Bull JJ (1993) An empirical test of bootstrapping as a method for assessing the confidence in phylogenetic analysis. Syst Biol 42:182-192

Huelsenbeck JP, Ronquist F (2001) MRBAYES: Bayesian inference of phylogenetic trees. Bioinformatics 17:754-755 
Humphreys AM, Linder HP (2009) Concept versus data in delimitation of plant genera. Taxon 58:1054-1074

Ilkiu-Borges AL (2005) A taxonomic monograph of the genus Prionolejeunea (Lejeuneaceae, Jungermanniopsida). Cuvillier, Göttingen

Janssen T, Kreier HP, Schneider H (2007) Origin and diversification of African ferns with special emphasis on Polypodiaceae. Brittonia 59:159-181

Larget B, Simon DL (1999) Markov chain Monte Carlo algorithms for the Bayesian analysis of phylogenetic trees. Molec Biol Evol 16:750-759

Lopez LCS, Oena Rodrigues PJF, Rios RI (1999) Frogs and snakes as phoretic dispersal agents of bromeliad ostracods (Limnicytherideae: Elpidium) and annelids (Naididae: Dero). Biotropica 31:705-708

Lopez LCS, Filizola B, Deiss I, Rios RI (2005) Phoretic behavior of bromeliad annelids (Dero) and ostracods (Elpidium) using frogs and lizards as dispersal vectors. Hydrobiologia 549:15-22

Mason-Gamer RJ, Kellogg EA (1996) Testing for phylogenetic conflict among molecular data sets in the tribe Triticeae (Gramineae). Syst Biol 45:524-545

Ramaiya M, Johnston MG, Shaw B, Heinrichs J, Hentschel J, von Konrat M, Davison PG, Shaw AJ (2010) Morphologically cryptic biological species within the liverwort, Frullania asagrayana. Amer J Bot 97:1707-1718

Rambaut A, Drummond AJ (2003) Tracer v1.3, available from $<$ http://evolve.zoo.ox.ac.uk/>

Rouhan G, Labiak PH, Randrianjohany E, Rakotondrainibe F (2012) Not so Neotropical after all: the grammitid fern genus Leucotrichum(Polypodiacea) is also Paleotropical, as revealed by a new species from Madagascar. Syst Bot 37:331-338 
Schuster RM (1992) The oil-bodies of the Hepaticae II. Lejeuneaceae. J Hattori Bot Lab 72:163-359

Schuster RM (1994) Studies on Lejeuneaceae, I. Preliminary studies on new genera of Lejeuneaceae. J Hattori Bot Lab 75:211-235

Swofford DL (2000) PAUP*, phylogenetic analyses using parsimony (* and other methods), version 4.01b10. Sinauer Associates, Sunderland, Massachusetts

Wilson R, Gradstein SR, Schneider H, Heinrichs J (2007) Unravelling the phylogeny of Lejeuneaceae (Jungermanniopsida): evidence for four main lineages. Molec Phylogen Evol 43:270-282

Ye W, Wei YM, Schäfer-Verwimp A, Zhu RL (2013) Phylogenetic position of Oryzolejeunea (Lejeuneaceae, Marchantiophyta): Evidence from molecular markers and morphology. J Syst Evol. doi:10.1111/j.1759-6831.2012.00238.x

Yu Y, Pócs T, Schäfer-Verwimp A, Heinrichs J, Zhu RL, Schneider H (2013) Evidence for rampant homoplasy in the phylogeny of the epiphyllous liverwort genus Cololejeunea (Lejeuneaceae). Syst Bot 38(3) (in press) 


\section{Table 1}

Taxa used in the present study, including information about the origin of the studied material, voucher information, as well as GenBank accession numbers

\begin{tabular}{lllll}
\hline Taxon & Voucher & rbcL & trnL-F & nrITS \\
\hline Anoplolejeunea conferta & Ecuador, Wilson et al.04-08 & DQ983653 & DQ987438 & DQ987335 \\
(C.F.W. Meissn.) A. Evans & (GOET) & & & \\
\hline Aureolejeunea & Ecuador, Schäfer-Verwimp \& & DQ983658 & DQ987450 & DQ987350 \\
$\begin{array}{l}\text { quinquecarinata R.M. } \\
\text { Schust. }\end{array}$ & Preußing 23299/A (GOET) & & & \\
\end{tabular}

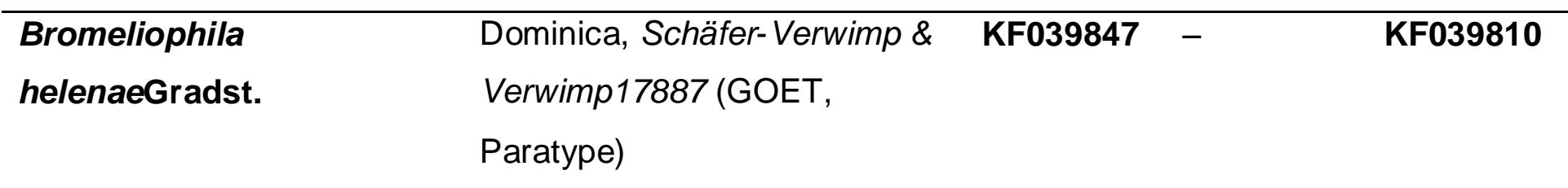

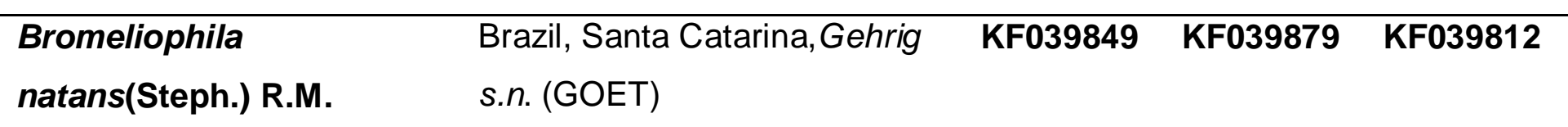

Schust.

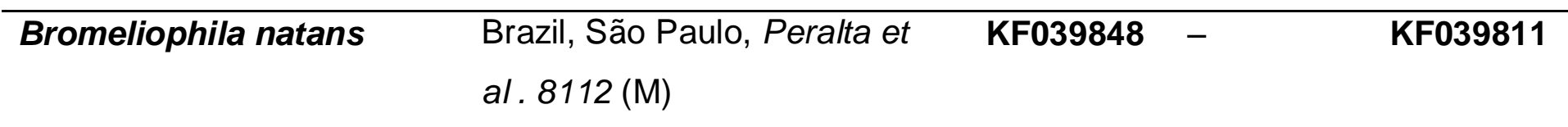

\begin{tabular}{lllll}
\hline Ceratolejeunea & Bolivia, Drehwald 4739(GOET) & AY548088 & DQ238570 & DQ987257
\end{tabular}
cornuta(Lindenb.) Steph.

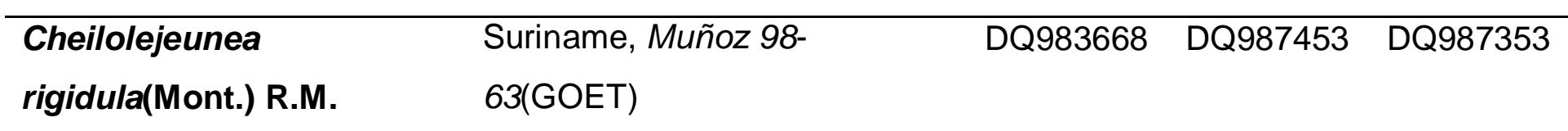

Schust.

\begin{tabular}{lllll}
\hline $\begin{array}{l}\text { Cololejeunea peculiaris } \\
\text { (Herzog) Benedix }\end{array}$ & $\begin{array}{l}\text { Malaysia, Schäfer-Verwimp \& } \\
\text { Verwimp 18861/A (GOET) }\end{array}$ & AY548095 & DQ238572 & DQ987280 \\
\hline $\begin{array}{lllll}\text { Colura tenuicornis (A. } \\
\text { Evans) Steph. }\end{array}$ & $\begin{array}{l}\text { Dominican } \\
\text { Republic, Schäfer-Verwimp \& } \\
\end{array}$ & & & \\
& Verwimp 27039 (JE) & & & \\
\hline Cyclolejeunea accedens & Costa Rica, San & KF039826 & KF039858 & KF039788
\end{tabular}




\begin{tabular}{|c|c|c|c|c|}
\hline (Gottsche) A. Evans & $\begin{array}{l}\text { José, Schäfer-Verwimp \& } \\
\text { Holz279/A (M) }\end{array}$ & & & \\
\hline Cyclolejeunea accedens & $\begin{array}{l}\text { Ecuador (I), Zamora- } \\
\text { Chinchipe, Schäfer-Verwimp \& } \\
\text { Nebel } 31964 / B(\mathrm{M})\end{array}$ & KF039824 & - & KF039786 \\
\hline Cyclolejeunea accedens & $\begin{array}{l}\text { Ecuador (II), Zamora- } \\
\text { Chinchipe, Schäfer-Verwimp \& } \\
\text { Nebel } 31949 / B(M)\end{array}$ & KF039825 & - & KF039787 \\
\hline $\begin{array}{l}\text { Cyclolejeunea } \\
\text { chitonia(Taylor) A. Evans }\end{array}$ & $\begin{array}{l}\text { French Guiana, Holz FG-00- } \\
124 \text { (GOET) }\end{array}$ & KF039844 & KF039875 & KF039806 \\
\hline Cyclolejeunea chitonia & $\begin{array}{l}\text { Guadeloupe (I), Schäfer- } \\
\text { Verwimp \& Verwimp 22130/A } \\
\text { (M) }\end{array}$ & KF039845 & KF039876 & KF039807 \\
\hline Cyclolejeunea chitonia & $\begin{array}{l}\text { Guadeloupe (II), Schäfer- } \\
\text { Verwimp \& Verwimp 22218/A } \\
\text { (M) }\end{array}$ & - & KF039877 & KF039808 \\
\hline Cyclolejeunea chitonia & $\begin{array}{l}\text { Panama, Schäfer-Verwimp \& } \\
\text { Verwimp } 30724(\mathrm{M})\end{array}$ & KF039846 & KF039878 & KF039809 \\
\hline $\begin{array}{l}\text { Cyclolejeunea } \\
\text { convexistipa (Lehm. \& } \\
\text { Lindenb.) A. Evans }\end{array}$ & $\begin{array}{l}\text { Brazil, São Paulo, Schäfer- } \\
\text { Verwimp \& Verwimp } 11621 \text { (M) }\end{array}$ & KF039839 & KF039871 & KF039801 \\
\hline $\begin{array}{l}\text { Cyclolejeunea } \\
\text { convexistipa }\end{array}$ & $\begin{array}{l}\text { Costa Rica, Schäfer-Verwimp } \\
\text { \& Holz 300/D (M) }\end{array}$ & KF039838 & KF039870 & KF039800 \\
\hline $\begin{array}{l}\text { Cyclolejeunea } \\
\text { convexistipa }\end{array}$ & $\begin{array}{l}\text { Ecuador (I), } \\
\text { Orellana, Schäfer-Verwimp \& } \\
\text { Nebel } 32820(\mathrm{M})\end{array}$ & KF039842 & KF039873 & KF039804 \\
\hline $\begin{array}{l}\text { Cyclolejeunea } \\
\text { convexistipa }\end{array}$ & $\begin{array}{l}\text { Ecuador (II), Zamora- } \\
\text { Chinchipe, Schäfer-Verwimp \& }\end{array}$ & KF039835 & KF039867 & KF039797 \\
\hline
\end{tabular}


Preussing 23427 (M)

\begin{tabular}{lllll}
\hline $\begin{array}{l}\text { Cyclolejeunea } \\
\text { convexistipa }\end{array}$ & Ecuador (III), Zamora- & KF039836 & KF039868 & KF039798 \\
& Chinchipe, Schäfer-Verwimp \& & & & \\
& Preussing 23408/F $(\mathrm{M})$ & & & \\
& & &
\end{tabular}

\begin{tabular}{lllll}
\hline $\begin{array}{l}\text { Cyclolejeunea } \\
\text { convexistipa }\end{array}$ & $\begin{array}{l}\text { Ecuador (IV), } \\
\text { Tunguragua, Gradstein et al . } \\
\text { 10039(GOET) }\end{array}$ & & & \\
& & & \\
\hline $\begin{array}{l}\text { Cyclolejeunea } \\
\text { convexistipa }\end{array}$ & French Guiana (I), Hartmann & KF039840 & - & KF039802 \\
& \& Riet 04/109(GOET) & & & \\
\hline $\begin{array}{l}\text { Cyclolejeunea } \\
\text { convexistipa }\end{array}$ & French Guiana (II), Holz FG00- & & DQ207904 & DQ207882 \\
& 0157 (GOET) & &
\end{tabular}

\begin{tabular}{lllll}
\hline $\begin{array}{l}\text { Cyclolejeunea } \\
\text { convexistipa }\end{array}$ & $\begin{array}{l}\text { Guyana, Kennedy \& Pulles } \\
4739(\text { GOET })\end{array}$ & KF039837 & KF039869 & KF039799 \\
\hline $\begin{array}{l}\text { Cyclolejeunea } \\
\text { convexistipa }\end{array}$ & $\begin{array}{l}\text { Panama, Schäfer-Verwimp \& } \\
\text { Verwimp 30786 (M) }\end{array}$ & KF039841 & KF039872 & KF039803 \\
& Verwim & & & \\
\hline
\end{tabular}

\begin{tabular}{lllll}
\hline $\begin{array}{l}\text { Cyclolejeunea } \\
\text { foliorum(Nees) Grolle }\end{array}$ & $\begin{array}{l}\text { Ecuador (I), } \\
\text { Orellana, Schäfer-Verwimp \& } \\
\text { Nebel 32784 (M) }\end{array}$ & & KF039865 & KF039795 \\
& $\begin{array}{l}\text { KF0333 } \\
\text { Cyclolejeunea foliorum }\end{array}$ & $\begin{array}{l}\text { Ecuador (II), Zamora- } \\
\text { Chinchipe, Schäfer-Verwimp \& } \\
\text { Nebel 32104/A(M) }\end{array}$ & & \\
& Colombia, Balcaza \& Ajarce & - & DQ207906 & DQ207884 \\
\hline $\begin{array}{l}\text { Cyclolejeunea } \\
\text { luteola(Spruce) Grolle }\end{array}$ & 919 (GOET) & & KF03986796 \\
\hline
\end{tabular}

\begin{tabular}{lllll}
\hline Cyclolejeunea luteola & $\begin{array}{l}\text { Dominica, Schäfer-Verwimp \& } \\
\text { Verwimp 17866 (M) }\end{array}$ & KF039823 & KF039857 & KF039785 \\
& & & & \\
\hline Cyclolejeunea luteola & Ecuador, Zamora-Chinchipe, & KF039821 & KF039855 & KF039783 \\
& Schäfer-Verwimp \& Preussing & & & \\
& $23356(\mathrm{M})$ & & &
\end{tabular}




\begin{tabular}{|c|c|c|c|c|}
\hline Cyclolejeunea luteola & $\begin{array}{l}\text { Jamaica, Gradstein } \\
6353(\mathrm{GOET})\end{array}$ & KF039822 & KF039856 & KF039784 \\
\hline Cyclolejeunea luteola & $\begin{array}{l}\text { Panama, Schäfer-Verwimp \& } \\
\text { Verwimp } 30955 \text { (M) }\end{array}$ & KF039820 & KF039854 & KF039782 \\
\hline $\begin{array}{l}\text { Cyclolejeunea peruviana } \\
\text { (Lehm. \& Lindenb.) A. } \\
\text { Evans }\end{array}$ & $\begin{array}{l}\text { Brazil, São Paulo, Schäfer- } \\
\text { Verwimp \& Verwimp 11621/A } \\
\text { (M) }\end{array}$ & KF039831 & KF039863 & KF039793 \\
\hline Cyclolejeunea peruviana & $\begin{array}{l}\text { Colombia, Gradstein } \\
8546(\mathrm{GOET})\end{array}$ & DQ983672 & DQ987383 & DQ207885 \\
\hline Cyclolejeunea peruviana & $\begin{array}{l}\text { Costa Rica, Schäfer-Verwimp } \\
\& \text { Holz 280/A (M) }\end{array}$ & KF039827 & KF039859 & KF039789 \\
\hline Cyclolejeunea peruviana & $\begin{array}{l}\text { Dominica, Schäfer-Verwimp \& } \\
\text { Verwimp 17737/A (M) }\end{array}$ & KF039828 & KF039860 & KF039790 \\
\hline Cyclolejeunea peruviana & $\begin{array}{l}\text { Ecuador (I), } \\
\text { Pichincha, Schäfer-Verwimp } \\
\text { et al . 24126/A (M) }\end{array}$ & KF039832 & KF039864 & KF039794 \\
\hline Cyclolejeunea peruviana & $\begin{array}{l}\text { Ecuador (II), Zamora- } \\
\text { Chinchipe, Schäfer-Verwimp \& } \\
\text { Preussing } 23352 \text { (M) }\end{array}$ & KF039829 & KF039861 & KF039791 \\
\hline Cyclolejeunea peruviana & $\begin{array}{l}\text { Ecuador (III), Zamora- } \\
\text { Chinchipe, Schäfer-Verwimp \& } \\
\text { Nebel 31956(M) }\end{array}$ & KF039830 & KF039862 & KF039792 \\
\hline $\begin{array}{l}\text { Diplasiolejeunea pellucida } \\
\text { (C.F.W. Meissn. ex } \\
\text { Spreng.) Schiffn. }\end{array}$ & $\begin{array}{l}\text { Ecuador, Schäfer-Verwimp et } \\
\text { al. } 24134(G O E T)\end{array}$ & JQ729500 & JQ729607 & JQ729383 \\
\hline $\begin{array}{l}\text { Drepanolejeunea } \\
\text { anoplantha (Spruce) } \\
\text { Steph. }\end{array}$ & $\begin{array}{l}\text { Dominican } \\
\text { Republic, Schäfer-Verwimp \& } \\
\text { Verwimp } 27059 \text { (JE) }\end{array}$ & KC313120 & KC313159 & KC313080 \\
\hline
\end{tabular}




\begin{tabular}{lllll}
\hline $\begin{array}{l}\text { Echinolejeunea papillata } \\
\text { (Mitt.) R.M. Schust. }\end{array}$ & New Zealand, Schäfer- & KC313135 & KC313175 & KC313097 \\
& Verwimp \& Verwimp 13967 & & & \\
& (JE) & & & \\
\hline Harpalejeunea & Azores, Schäfer-Verwimp \& & KC313148 & KC313188 & KC313110 \\
molleri(Hook. f \& Tayl.) & Verwimp 29334 (JE) & & & \\
Grolle & & & & \\
\hline
\end{tabular}

\begin{tabular}{lllll}
\hline Lejeunea cavifolia(Ehrh.) & Germany, Heinrichs & AY548102 & DQ238581 & DQ987259 \\
Lindb. & 3695 (GOET) & & & \\
& & & &
\end{tabular}

\begin{tabular}{lllll}
\hline Lepidolejeunea delessertii & Réunion, Schäfer-Verwimp \& & KF039819 & KF039853 & KF039781 \\
(Nees \& Mont.) Grolle & Verwimp 20355/B(M) & & &
\end{tabular}

\begin{tabular}{lllll}
\hline Lepidolejeunea & Bolivia, Churchill \& Vasquez & AY548066 & DQ238579 & DQ987266 \\
eluta(Nees) R.M. Schust. & 21800 (GOET) & & & \\
\hline
\end{tabular}

\begin{tabular}{lllll}
\hline Lepidolejeunea & Fiji Isls., Pócs 3307/AC(GOET) & DQ983697 & DQ987417 & DQ987313
\end{tabular}
integristipula (J.B. Jack \&

Steph.) R.M. Schust.

\begin{tabular}{lllll}
\hline Luteolejeunea & Costa Rica, Schäfer-Verwimp & DQ983706 & DQ987467 & DQ987368 \\
herzogii(Buchloh) Piippo & $\&$ Holz 0294/B(GOET) & & &
\end{tabular}

\begin{tabular}{lllll}
\hline $\begin{array}{l}\text { Marchesinia robusta(Mitt.) } \\
\text { Schiffn. }\end{array}$ & $\begin{array}{l}\text { Ecuador, Wilson et al. 04-05 } \\
\text { (GOET) }\end{array}$ & DQ983710 & DQ987436 & DQ987332 \\
\hline Mastigolejeunea & Bolivia, Churchill & AY548070 & DQ987385 & DQ987268 \\
auriculata (Wilson \& & $21275(G O E T)$ & & &
\end{tabular}
Hook.) Schiffn.

\begin{tabular}{lllll}
\hline $\begin{array}{l}\text { Microlejeunea } \\
\text { africanaSteph. }\end{array}$ & $\begin{array}{l}\text { São Tomé \& } \\
\text { Principe, Shevock 34576A } \\
\end{array}$ & KC313150 & KC313190 & KC313112 \\
& (GOET) & & & \\
\hline Myriocoleopsis & Ecuador, Gradstein et al . & DQ238568 & DQ & DQ987277 \\
gymnocolea (Steph.) M.E. & 10020 (GOET) & & 238583 &
\end{tabular}

Reiner \& Gradst. 


\begin{tabular}{lllll}
\hline $\begin{array}{l}\text { Omphalanthus filiformis } \\
\text { Nees }\end{array}$ & $\begin{array}{l}\text { Ecuador, Schäfer-Verwimp \& } \\
\text { Preußing 23543 (GOET) }\end{array}$ & DQ983716 & DQ983793 & DQ987283 \\
\hline
\end{tabular}

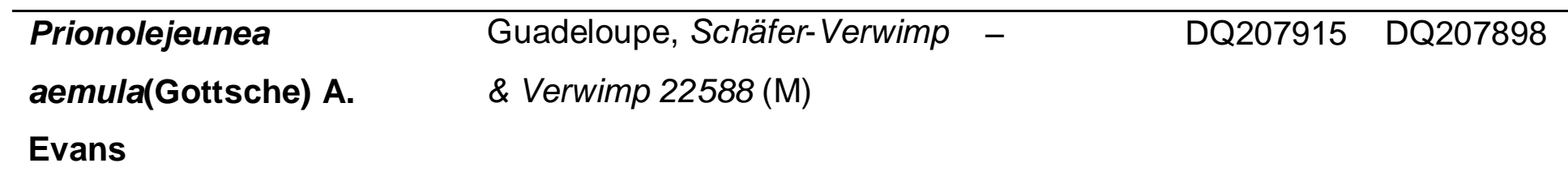

\begin{tabular}{lllll}
\hline Prionolejeunea & Dominica, Schäfer-Verwimp \& & KF039851 & KF039881 & KF039816 \\
decora(Taylor) Steph. & Verwimp 18028 (M) & & & \\
\hline
\end{tabular}

\begin{tabular}{lllll}
\hline Prionolejeunea decora & $\begin{array}{l}\text { Guadeloupe (I), Schäfer- } \\
\text { Verwimp \& Verwimp 22308 (M) }\end{array}$ & DQ207919 & DQ207890 \\
& $\begin{array}{l}\text { Guadeloupe (II), Schäfer- } \\
\text { Verwimp \& Verwimp 22263 (M) }\end{array}$ & KF039880 & KF039815 \\
\hline Prionolejeunea decora & & &
\end{tabular}

\section{Prionolejeunea}

galliotiiSteph.

Prionolejeunea

grata(Gottsche) Schiffn.
Panama, Reiner-Drehwald $\quad-\quad$ DQ907923 $\quad$ DQ207886

960026 (GOET)

Réunion, Pócs 08056/W(M) - - -

KF039818

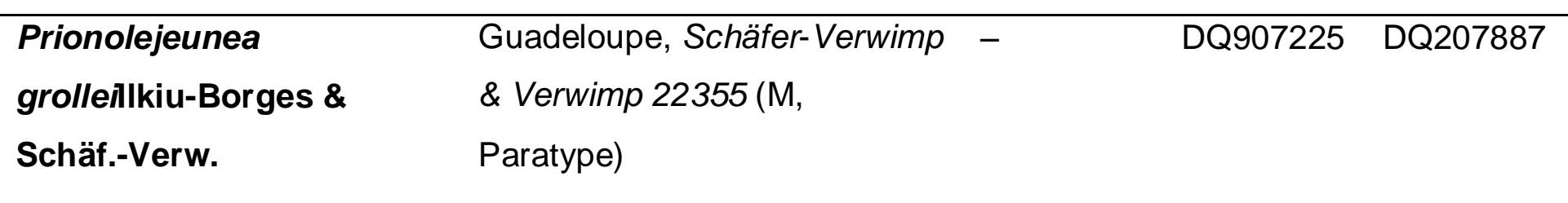

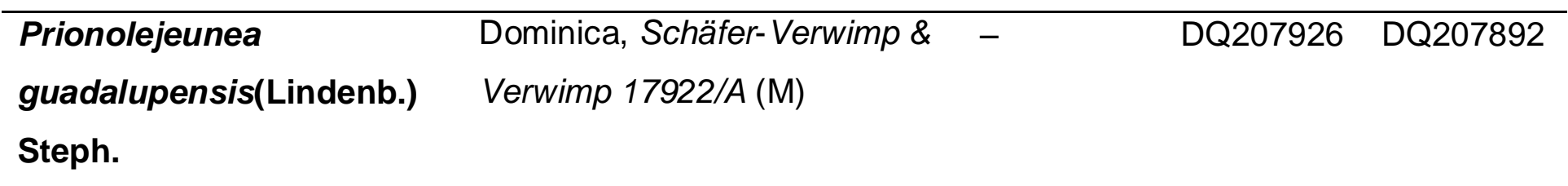

\begin{tabular}{|c|c|c|c|c|}
\hline Prionolejeunea & Brazil, Schäfer-Verwimp \& & KF039850 & DQ207928 & DQ207895 \\
\hline limpidaHerzog & Verwimp 13291 (M) & & & \\
\hline Prionolejeunea & Colombia, Gradstein & - & DQ207929 & DQ207896 \\
\hline magnistipula Herzog & 8964(GOET) & & & \\
\hline $\begin{array}{l}\text { Prionolejeunea mucronata } \\
\text { (Sande Lac.) Steph. }\end{array}$ & $\begin{array}{l}\text { Costa Rica, Schäfer-Verwimp } \\
\& \text { Holz } 287(\mathrm{M})\end{array}$ & KF039852 & - & KF039817 \\
\hline
\end{tabular}

\begin{tabular}{lllll}
\hline Prionolejeunea scaberula & French Guiana, Holz FG-0012 & - & DQ207934 & DQ207889
\end{tabular} 


\begin{tabular}{|c|c|c|c|c|}
\hline (Spruce) Zwickel & $(\mathrm{GOET})$ & & & \\
\hline Prionolejeunea scaberula & $\begin{array}{l}\text { Guadeloupe, Schäfer-Verwimp } \\
\text { \& Verwimp 22184/B(M) }\end{array}$ & - & DQ207933 & DQ207888 \\
\hline $\begin{array}{l}\text { Prionolejeunea schlimiana } \\
\text { (Gottsche) Steph. }\end{array}$ & $\begin{array}{l}\text { Costa Rica, Dauphin } \\
2115(\mathrm{GOET})\end{array}$ & - & DQ207935 & DQ207893 \\
\hline Prionolejeunea schlimiana & $\begin{array}{l}\text { Ecuador (I), Andersson \& } \\
\text { Kautz } 3202 \text { (GOET) }\end{array}$ & - & DQ207936 & DQ207894 \\
\hline Prionolejeunea schlimiana & $\begin{array}{l}\text { Ecuador (II), Schäfer-Verwimp } \\
\text { \& Nebel } 33210(\mathrm{M})\end{array}$ & - & - & KF039814 \\
\hline $\begin{array}{l}\text { Prionolejeunea } \\
\text { trachyodes (Spruce) } \\
\text { Steph. }\end{array}$ & $\begin{array}{l}\text { Panama, Schäfer-Verwimp \& } \\
\text { Verwimp } 30778(\mathrm{M})\end{array}$ & - & - & KF039813 \\
\hline $\begin{array}{l}\text { Rectolejeunea berteroana } \\
\text { (Gottsche) A. Evans }\end{array}$ & $\begin{array}{l}\text { Guadeloupe, Schäfer-Verwimp } \\
\text { \& Verwimp 22245/A (GOET) }\end{array}$ & DQ983724 & DQ987444 & DQ987342 \\
\hline $\begin{array}{l}\text { Siphonolejeunea } \\
\text { elegantissima (Steph.) } \\
\text { Grolle }\end{array}$ & $\begin{array}{l}\text { Australia, Pócs \& } \\
\text { Brown0026/AA (EGR) }\end{array}$ & DQ983726 & DQ987452 & DQ987352 \\
\hline
\end{tabular}

Accession numbers of new sequences are in bold face

\section{Table 2}

Distribution of constant and phylogenetically informative sites for aligned positions of the three genomic regions (1. Lejeuneeae dataset, 2. Bromeliophila-CyclolejeuneaPrionolejeunea dataset)

\begin{tabular}{lllll}
\hline & rbcL & trnL-trnF & ITS1-5.8S-ITS2 & Total \\
\hline Number of sites in matrix & $914 / 936$ & $433 / 435$ & $668 / 920$ & $2,015 / 2,291$ \\
\hline Constant & $720 / 793$ & $268 / 327$ & $333 / 430$ & $1,321 / 1,550$ \\
\hline Unique to a single specimen & $90 / 48$ & $73 / 49$ & $90 / 114$ & $253 / 211$ \\
\hline Parsimony informative & $104 / 95$ & $92 / 59$ & $245 / 376$ & $441 / 530$ \\
\hline
\end{tabular}




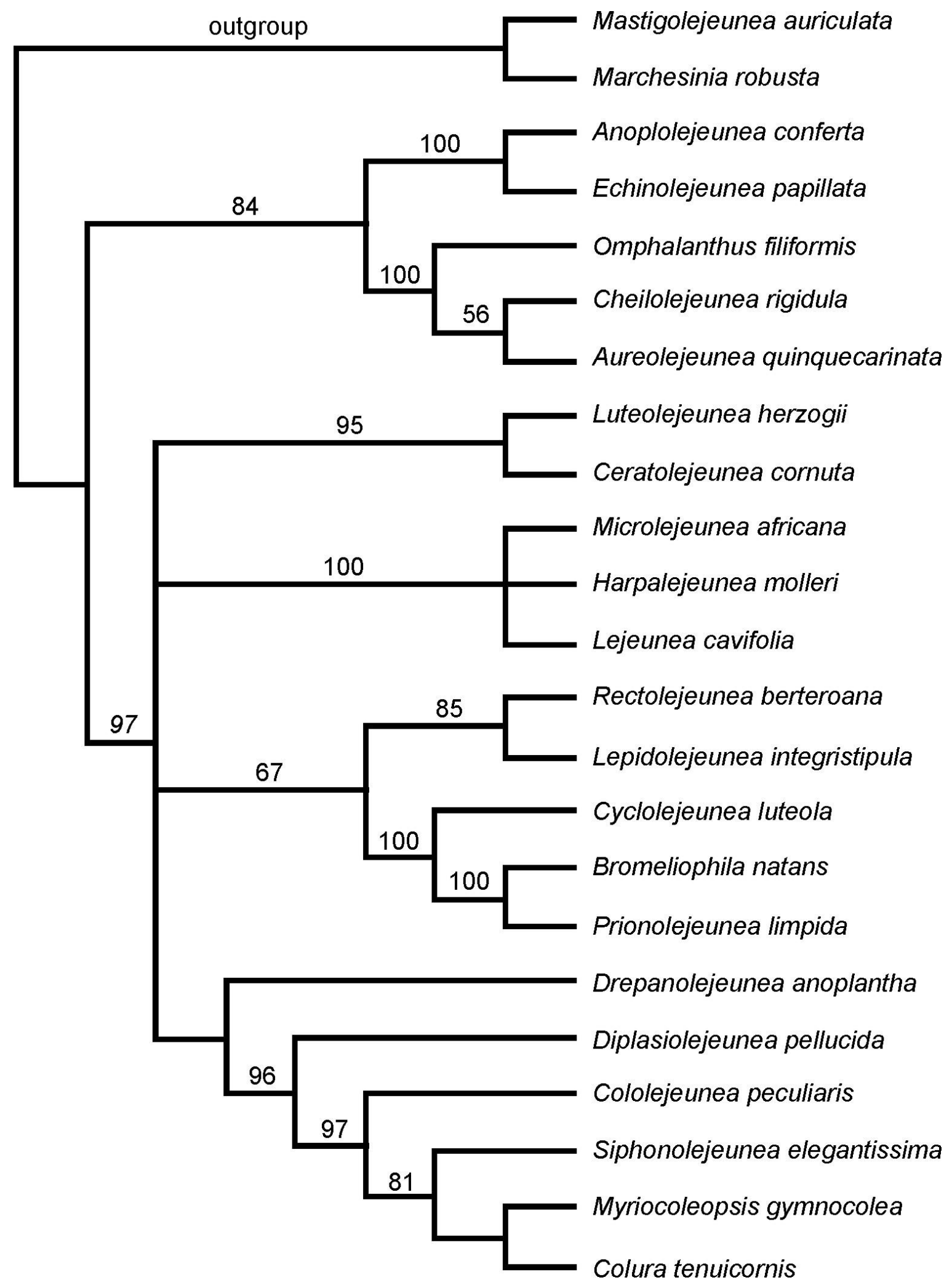

Fig. 1 Strict consensus of four equally parsimonious trees. Bromeliophila is placed sister to Prionolejeunea rather than Lejeunea 


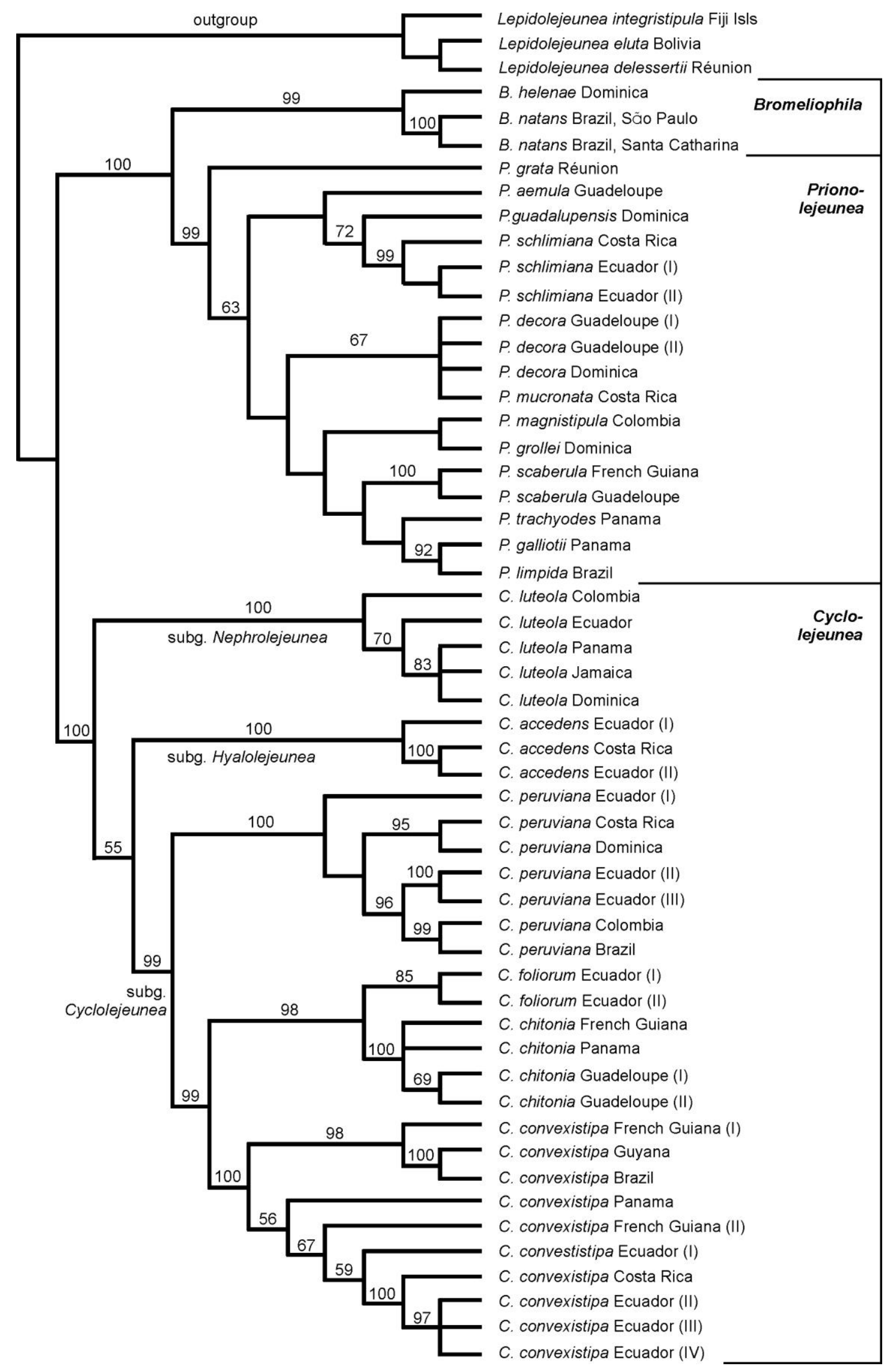

Fig. 2 Rooted strict consensus of 156 most parsimonious trees recovered during heuristic searches of the combined rbcL-trnL-F-nrITS dataset. Bootstrap percentage values $>50$ are indicated at branches 


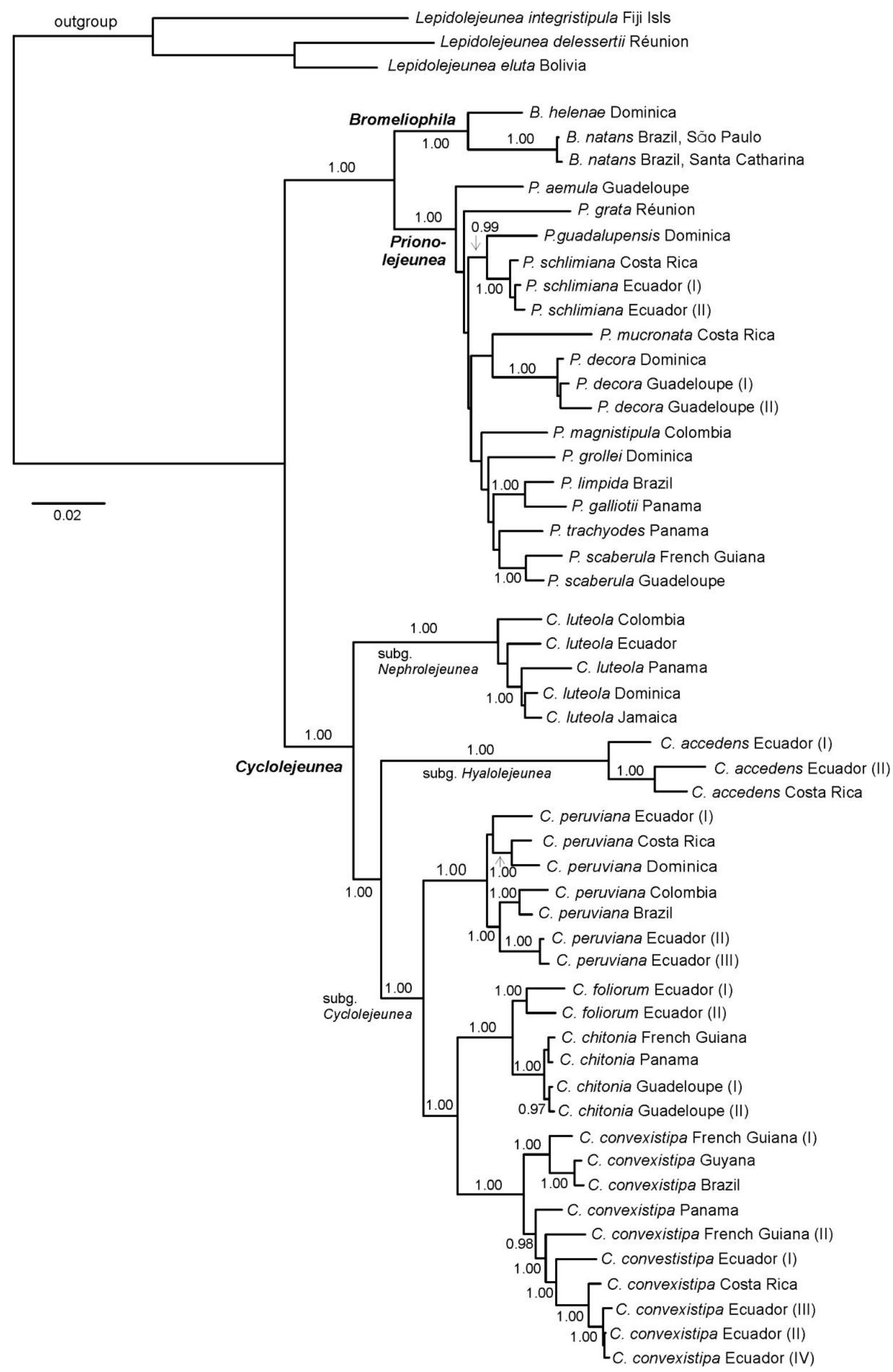

Fig. 3 Majority rule consensus tree of trees recovered in stationary phase of Bayesian search. Support ( $\geq 0.95)$ from Bayesian searches is indicated at branches 


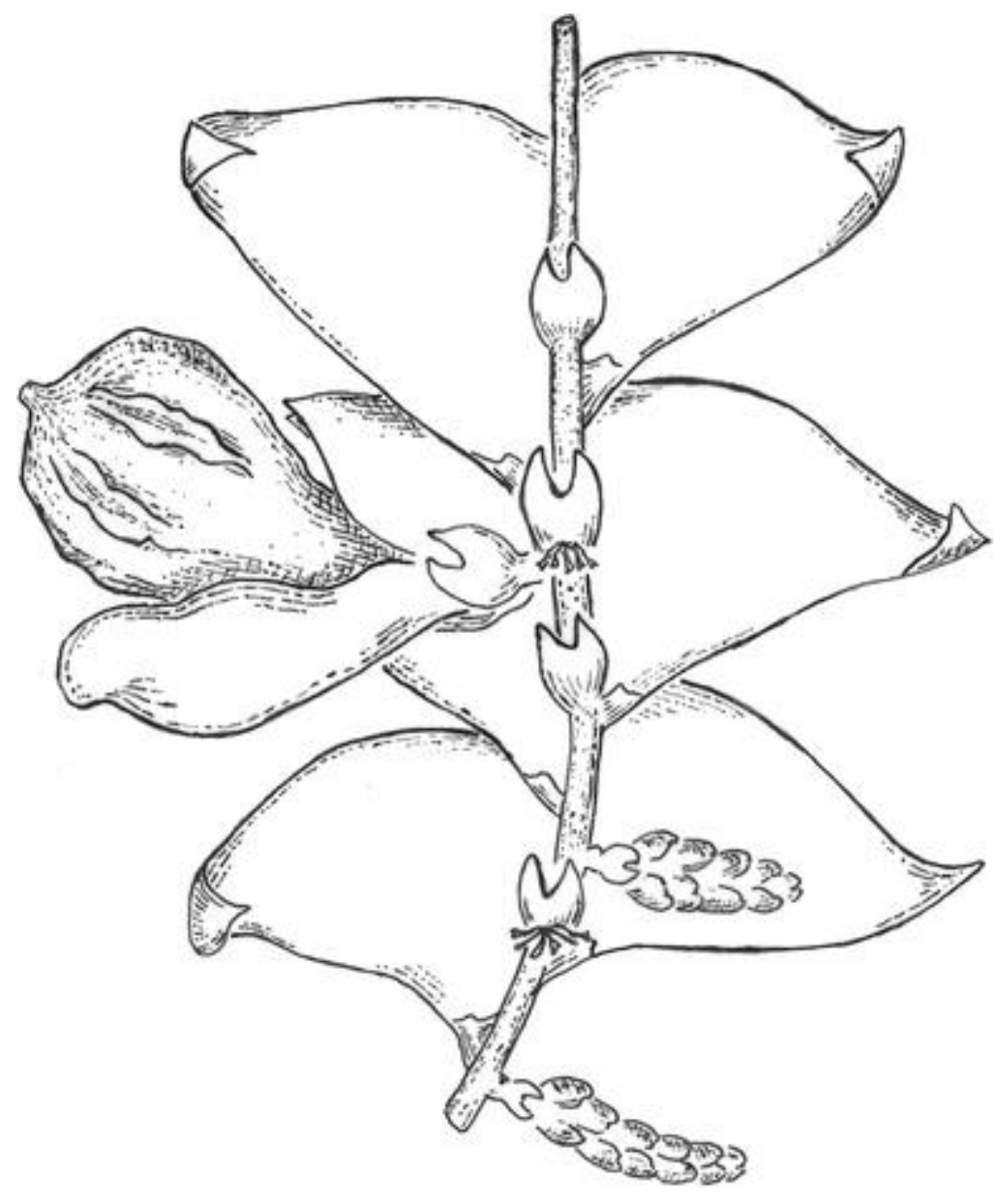

Fig. 4 Bromeliophila natans, part of shoot with perianth and two androecia, ventral view [drawn from Peralta et al. $8112(\mathrm{M})$ ] 


\section{Acknowledgments}

First of all, I would like to thank my supervisor Prof. Dr. Jochen Heinrichs for giving me the opportunity to study at the department of Systematic Botany in Göttingen. Many thanks for his help with specimens, discussion, and literature. I am also very grateful to PD. Dr. Alexander Schmidt as he co-supervised my work with Prof. Heinrichs. Many thanks for their kind supervision, continuous guidance and helpful discussion throughout the duration of my thesis. Financial support from China Scholarship Council awarded to me is gratefully acknowledged (CSC No. 2010697001).

I would also like to thank Prof. Dr. Elvira Hoerandl, Prof. Dr. Hermann Behling and Prof Dr. Markus Hauck for agreeing to be my thesis committee members. I am also very grateful to Dr. Harald Schneider for his helpful discussion with biogeography and Dr. Alfons Schäfer-Verwimp for his help and discussion with specimens and morphology. Thanks also to Dr. Kathrin Feldberg and Dr. Hans-Peter Kreier for their help with my lab work and computer program. I would also like to thank Dr. M. Elena Reiner-Drehwald for her literature and help with morphology and Dr. Simone Klatt for her cordial help with the computer software.

Special thanks go to Tamás Pócs (Eger, Hungary), Matt von Konrat (Chicago, USA), Gregorio Dauphin (San José, Costa Rica), Hironori Deguchi (Hiroshima, Japan), Alfons Schäfer-Verwimp (Herdwangen-Schönach, Germany) and Elena Reiner-Drehwald (Götttingen) for their support in specimen materials. In addition, I would like to thank all the other staff and colleagues in the Department of Systematic Botany and Courant Center. Thanks are also to the fellows in Experimental Phycology \& Culture Collection of Algae group and Institute of Human Genetics for assistance of lab work and for sequencing. Last but by no means least, thank you to all my friends and family! 


\section{Curriculum vitae}

\section{Personal}

Born in Shaanxi Province, China, on Nov. $21^{\text {th }}, 1984$

Contact information

Address for correspondence:

Department of Systematic Botany, Albrecht von Haller Institute of Plant Sciences, Georg August University, Untere Karspüle 2, 37073 Göttingen, Germany

E-mail: shanshan.dong@stud.uni-goettingen.de

Phone: +495513922014

\section{Education}

2010.10 -present Department of Systematic Botany, University of Goettingen, Germany

Doctoral studies: Phylogeny and Biogeography of leafy liverworts

Thesis title: Systematics and biogeography of several genera in subfamily Lejeunoideae

2007.09-2010.07 College of Life Science, Northwest University Shaanxi, China Master of Science: Plant Population Genetics

Thesis title: A Study on Population Structure of Saruma henryi Oliv. in China by using genomic SSR Markers (developed by myself)

\subsection{9-2007.07 College of Life Science, Northwest University Shaanxi, China}

Bachelor of Science, Biotechnology

Thesis title: A preliminary Study on Molecular Systematics of Dipteronia Oliv. Population based upon Chloroplast DNA Sequences 